\section{DISCLAIMER}

This report was prepared as an account of work sponsored by an agency of the United Statea Government. Neither the United States Government nor any agency thereof, nor any of their enployces, makes any warranty, express or implied, or assumes any leqal lisbility or responsibility for the accuracy, completeness, or usefulness of any information, epparatus, product, or froces disclosed, or reprewents that its use would not infringe privately owned rights. Refereace herein to any specific commercial product, process, or service by trade name, trademark, manufacturer, or otherwise does nut necesenrily constitute or imply its endorsement, recom. mendation, or favoring by the United Siates Government or any agency thereof. The views and opinions of suthon expressed herein do not necesserily state or reflect those of the United States Gowerament $x$ any agency thereof.

ANL-83-57

Part I
Distribution Category: Nuclear Waste Management (vc-70)

ANL--83-57-Pt. 1

DE84 000985

ARGONNE NATIONAI LABORATORY

9700 South Cass Avenue

Argonne, Illinois 60439

COMPATIBILITY OF TECHNOLOGIES WITH REGULATIONS

IN THE WASTE MANAGEMENT OF $\mathrm{H}-3, \mathrm{I}-129, \mathrm{C}-14$, AND $\mathrm{Kr}-85$.

PART I, INITIAL INFORMATION BASE

by

L. E. Trevorrow, G. F. Vandegrift, V. M. Kolba, and M. J. Steindler

Chemical Technology Division 


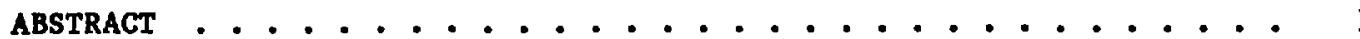

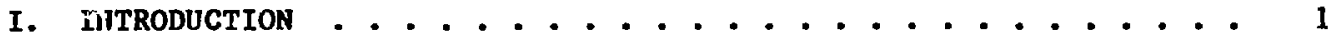

A. Function of this Report ............. 1

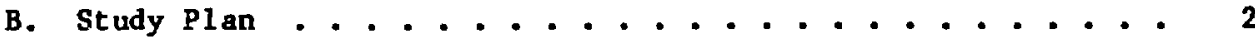

C. Scope of the study ................ 3

II. PRIMARY WASTE FORMS .................. 5

A. Occurrence of the Airborne Wastes ............ 5

B. Composition of the Primary Waste Stream . . . . . . . . 5

II I. TECHNOLOGIES OF AIRBORNE WASTE FORMS . . . . . . . . 7

A. Technology of Krypton Waste Forms . . . . . . . . 7

1. Decay Characteristics of Rrypton-85 .......... 7

2. Collection of krypton ............... 8

3. Inmobilization of Krypton .............. 12

B. Cements as Immobilizazion Media ............ 18

C. Technology of Tritiun Waste Forms . . . . . . . . 23

1. Decay Characteristics of Tritium .......... 23

2. Collection of Tritium ............... 23

3. Immobilization of Tritium ............ 26

D. Technologies of Iodine Waste Forms ........... 36

1. Decay Characterietica of I-129-Containing Waste Forms . . . . . . . . . . . . 36

2. Collection of Iodine ............. 39

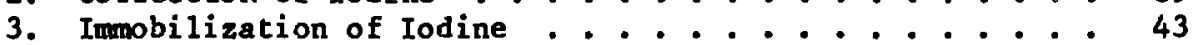

E. Technologies of Carbon Waste Forms . . . . . . . . 84

1. Decay Characteristics of C-14-Containing Material ............... 84

2. Collection of Carbon ............... 86

3. Immobilization of Carbon ............. 89

IV. SYSTEMS FOR PACKAGING, TRANSPORTATION, AND DISPOSAL . . . . . 96

A. Shallow-Land Burial (SLB) . . . . . . . . . 96

1. SLB Practices . . . . . . . . . . . . . . 96

2. Local Regulatory Authority for LLW Disposal . . . . . . 99

3. Federal Regulation of LLW Disposal .......... 99 
B. Greater Confinement Disposal (GCD) . . . . . . . . 103

1. Development of GCD ............... 103

2. Criteria Proposed for GCD .............. 107

C. Deep Geologic Disposal .................. . 111

1. Concepts of Deep-Geologic Disposal

Technology .................. 111

2. Criteria and Regulations for Deep-Geologic

Disposal .................. 116

D. Ocean Di sposal ................... . . 123

1. Practices in Ocean Disposal of LLW .......... 123

2. Criteria and Regulations for Ocean Disposal

of LLW. . . . . . . . . . . . . . . . . 125

3. Concepts for Ocean Diaposal of HLH . . . . . . . 129

E. Packaging . . . . . . . . . . . . . . 129

1. Current Federal Requirements on Packaging for

Transportation of Radioactive Materials . . . . . . 129

2. Packaging for Deep-Geologic Disposal . . . . . . . 139

3. Packaging for Shallow-L nd Burial .......... 140

F. Interim Storage . . . . . . . . . . . . . . 143

v. SUMMARY . . . . . . . . . . . . . . . 146

REFERENCES ...................... 147 
II-1. Generic Flow Scheme for Airborne Nuclides

in Fuel-Reprocessing Operations . . . . . . . . . . 6

III-1. Flow Schewe for Collection of $\mathrm{Kr}$ by Cryogenic

Distillation......................... 10

III-2. Flow Scheme for Collection of $\mathrm{Kr}$ by

Liquid Absorption ....................... 11

III-3. Flow Scheme for collection of $\mathrm{Kr}$ by

Adsorption on Solids. . . . . . . . . . . . . . . . 12

III-4. Four stages in the Setting and Hardening

of Portland Cement . . . . . . . . . . . . . . . . 20

III-5. Proposed Tritium collection Operations

in Aqueous Fuel Reprocessing . . . . . . . . . . . . . . . 26

III-6. Cross Section of the Mound Package for Disposal

of Tritiated Waste in a Cement-Plaster Matrix . . . . . . . 30

III-7. Solubility of $\mathrm{Ba}\left(\mathrm{IO}_{3}\right)_{2}$ vs. Temperature . . . . . . . . . . 44

III-8. The Effect of $\mathrm{NO}_{3}^{-}$and Ionic Strength (I) on

the Solubility of $\mathrm{Ba}\left(\mathrm{IO}_{3}\right)_{2}$ at $25^{\circ} \mathrm{C}$. . . . . . . . . 45

III-9. The Effect of Iodine Content on the Leach Rate

of Barium Iodate Concrete, No Additives ........... 50

III-10. Radiolytic Reduction of Iodate to Iodide in a

Barium Iodate Concrete Containing 9.05 wt 7

Iodine... . . . . . . . . . . . . . . . 55

III-11. Effect of the Addition of 1.8 wt $\bar{z}$ of $\mathrm{AB}_{2} \mathrm{O}$,

$\mathrm{HgO}$, or $\mathrm{PbO}$ on the Radiolytic Reduction of

Iodate to Iodide in Barium Iodate Concrete

Containing 9.05 w $\%$ lodine .............. 56

III-12. Solubility of AgI vs. Temperature . . . . . . . . . . . . . 60

III-13. Thermogravinetric Analyses for AgZ,

$A 8^{\circ} 2, A g X$, and AC-6120,................. 63

III-14. Effect of Iodine Loading Rate and Species on

the Thernal Release of Iodine from AgZI . . . . . . . . . . . 64

III-15. Block Diagram ,f Iodine Recovery Proces. . . . . . . . . . 66 
III-16. Water Loss vs. Time for Various Loadings of AgX in Concrete .................. 70

III-17. Density of Concrete Prepared from Pozzolanic Cenent and Silver-Exchanged Zeolite of Different Compositions ................. 71

III-18. Crush Strength of Concrete Sample v8. the Zeolite Content .............. 72

III-19. The Effect of $\mathrm{pH}$ on the Sorption of Iodide by Soil, Root Compost, Ferric Oxide, and Aluminum Oxide from Solutions Containing Initially $40 \mu \mathrm{Ig} / 100 \mathrm{~mL}$. . . . . 76

III-20. The Effect of Time on the Sorption of Iodide by Two Soils from Initial Iodide Concentrations of

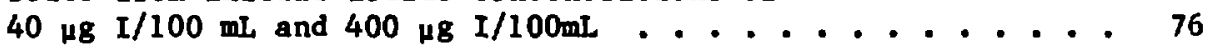

III-21. Sorption of Iodate by Hematite . . . . . . . . . 79

III-22. Adsorption of Iodate by Hematite as a Function of $\mathrm{pH}$ in $0.1 \mathrm{M} \mathrm{NaClO}_{4}$ Solution ............. 79

III-23. Sorption of Iodide Tracer Activity on $\mathrm{Cu}_{2} \mathrm{~S}$ and Bournonite as a Function of Time .............

III-24. Schematic of the Double Alkali $\mathrm{CO}_{2}$ Fixation Process ...................

III-25. Schematic of the Direct $\mathrm{CO}_{2}$ Fixation Process . . . . . . .

ilI-26. Solubility of $\mathrm{CaCO}_{3}$ and $\mathrm{BaCO}_{3}$ under Ambient Atmosphere v8. Temperature . . . . . . . . . . . .

III-27. The Solubility of Calcite vs. the Partial Pressure of $\mathrm{CO}_{2}$ Above the Solution at $25^{\circ} \mathrm{C}$. . . . . . . . 90

III-28. C-14 Static Leach Studies of ConcreteEncapsulated $\mathrm{CaCO}_{3}$.................. 93

III-29. (-14 IAEA Leach Studies of Concrete Encapsulated $\mathrm{BaCO}_{3}$ and $\mathrm{CaCO}_{3}$

IV-1. DOT Specification 20WC Packaging . . . . . . . . . 135

IV-2. DOT Specification 6M Packaging Including Spec 2R Inner Container . . . . . . . . . . . . . 135

IV-3. DOT Specification 6J Peckaging, Configuration A . . . . . 136 


\section{LIST OF FIGURES (contd)}

No.

TITLE

Page

IV-4. DOT Specification 6L Packaging . . . . . . . . . . . . 136

IV-5. Engineered Barrier Systen Compatible with Both Oxidizing and Anoxic Enviroments

Featuring Massivc Non-Metallic Hole Sleeve . . . . . . . . 141

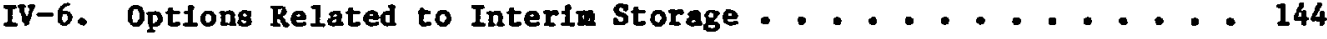




\section{LIST OF TABLES}

No.

III-1. Characteristics of the Radioactive Decay of Rr-85 . . . . .

III-2. Summary of Several Characterizations of Storage of $\mathrm{Kr}$ as Compressed Gas . . . . . . . . . . . . . . . 14

III-3. Characteristics of Zeolite Wayte Form for Storage of Krypton . . . . . . . . . . . . 16

III-4. Characteristics of Sputtered Metal Haste Form for Storage of Krypton ................. 17

III-5. Chemical Composition of Some Typical Cements . . . . . . . 21

III-6. Composition of Some Typical Cements in Terms of the Potential Compounds Formed in the Mix . . . . . . . . . 21

III-7. Compressive Strength of Concrete Waste Forms . . . . . . . 22

III-8. Characterization of the Mound Package for Disposal of Tritium in Cement ............. 29

III-9. Quantities of Zirconium Required to Fix Tritiated Aqueous Waste from Fuel Reprocessing as $\mathrm{ZrH}_{2}$. . . . . . . . . 34

III-10. Results of Leach Tests on Tritiated Zirconium Hydride . . . . . . . . . . . . . . . . 34

III-11. Thermal Stability of Tritiated Organic Compounds . . . . . 35

III-12. Radiation Stability of Organic Compounds Proposed as Tritium-stor age Forms . . . . . . . . . . . . . 36

III-13. Radioactive Decay of I-129, Radiation Types with Their Corresponding Energy, Intensity, and Energy Emitted per Disintegration..................

III-14. Fission Product Iodine from Spent LMFBR Fuel and Its Decay ................... 38

III-15. Amounts of Iodine Isotopes Found in 1 MTH of Different Reactor Fuels One Year After Discharge . . . . . . . . 39

III-16. Redox Potentials Pertinent to $\mathrm{Ba}\left(\mathrm{IO}_{3}\right)_{2}$ in Concrete...... 48

II1-17. Summary of Iodine Leach Study Results from $\mathrm{Ba}\left(\mathrm{IO}_{3}\right)$ in Concrete .................... 51

III-18. Effect of Different Leachants on the Iodine Diffusivity $\left(D_{e}\right)$ from $\mathrm{Ba}\left(\mathrm{IO}_{3}\right)_{2}$ in Concrete............... 
LIST OR TABLES (contd)

No.

III-19. Effect of Additives on the $G$ Values for the Production of $\mathrm{I}^{-}$Ion from $\mathrm{Ba}\left(\mathrm{IO}_{3}\right)_{2}$ in Concrete ........ 57

III-20. Properties of Commercially Available Molecular Sieves, Linde $13 \mathrm{X}$ and Zeolon 900 ............. 59

III-21. Volume Distribution in a single Molecular Sieve Pellet and in a Bed of Molecular Sieve Pellets . . . . . . . 59

III-22. Specification of Alumina-Base Adsorbent: Alcoa Alumina $\mathrm{H}-151$. . . . . . . . . . . . . . 60

III-23. Maximum and Practical Iodine Loading Capacities of Silver and Lead Sorbents . . . . . . . . . . . . . 62

III-24. Extrapolated Vapor Pressure of $I_{2}$ above $P b X I, P b Z I$, and $\mathrm{Pb}^{\circ}$ in $\mathrm{H}_{2}, \mathrm{~N}_{2}$, and Air Atmosphere at $20^{\circ} \mathrm{C} . . . . . . .65$

III-25. A Comparison of the Waste Disposal Forms for Various Solid Sorbents Alore or Encapsulated in Concrete ........................

III-26. Composition of Concrete Samples Prepared from Pozzolanic Cement and AgX Zeolite . . . . . . . . . . 71

III-27. Anion- and Cation-Exchange Capacities of Some Common Minerals . . . . . . . . . . . . . . 74

III-28. Distribution Ratio of Iodide between Activated Charcoal and Brine ................... 77

III-29. Distribution of Iodide and Iodate between Water of Differing pH Values and Activated Charcoal . . . . . . . 77

III-30. Distribution Ratio Values for Various Rocks and Minerals.................. 81

III-31. Fraction of Radiotracers Sorbed on Various Chemical Reagents ................ 82

III-32. Sorption of Iodate by Several Materials from Groundwater and Simulated WIPP Brine............ 82

III-33. Specific Activities and Thermal outputs of 140 Chenical Species . . . . . . . . . . . . 85

III-34. Summry of Carbonate Leaching Experiments . . . . . . . . 92

III-35. Distribution Coefficient vo. Contact Time . . . . . . . . 95 
IV-1. DOE sites for LLW Disposal . . . . . . . . . . . . . 97

IV-2. Maximun Concentrations of Airborne Wastes in Near-Surface Disposal Specified by 10 CFR 61 . . . . . . 102

IV-3. Proposed Area Concentration Disposal Limits for GCD of Airborne Wastes............... 110

IV-4. Proposed Waste Canister Characteristics . . . . . . . . . . 114

IV-5. Proposed Canister Acceptance Criteria . . . . . . . . . . 115

IV-6. Conceptual Packaging Characteristics for Deep-Geologic Disposal .................. 117

IV-7. Technical Criteria for Deep-Geologic Disposal . . . . . . 119

IV-8. Criteria and Characteristics of Deep-Geologic Isolation . . . . . . . . . . . . . 120

IV-9. Waste Form Requirements for DeepGeologic Disposal

IV-10. Waste Package Requirements for Deep-Geologic Disposal . . . . . . . . . . . . . . 122

IV-11. Summary of Information That May Be Required on Wastes destined for Geologic Disposal . . . . . . . . . . . . 124

IV-12. Agency Responsibilities in Packaging of Radioactive Materials for Transportation . . . . . . . . . . 130

IV-13. Assignment of $A_{2}$ Values to the Airborne Nuclides by Dor Regulations . . . . . . . . . . . . 132

IV-14. DOT-Authorized Packaging and Corresponding Quantities ... . . . . . . . . . . . . . 133

IV-15. Description of Specification Packaging . . . . . . . . . . . . 134

IV-16. Tests for Proposed Packagings: Normal Conditions of Transportation . . . . . . . . . . . . 138

IV-17. Tests for Proposed Packagings: Accident Conditions . . . . . . . . . . . . . . 138

IV-18. Radiation Dose Limits for ExclusiveUse Shipments . . . . . . . . . . . . . . . . 140 
NOMENCLATURE 


\section{NONENCLATURE}

AEC - Atomic Energy Comission

ALARA - As Low as Is Reasonably Achievable

ANL - Argonne National Laboratory

BNL - Brookhaven National Laboratory

BWR - Boiling Water Reactor

CFR - Code of Federal Regulations

CHW - Cladding Hulls Waste

DF - Decontamination Factor

DOE - Department of Energy

DOG - Dissolver off-Gas

DOT - Department of Transportation

DSC - Differential Scanning Calorimetry

EIS - Environmental Impact Statement

EPA - Environmental Protection Agency

ERDA - Energy Research and Development Administration

FAA - Federal Aviation Administration

FRP - Fuel Reprocessing Plant

GCD - Greater Confinement Disposal

HIP - Hot Isostatic Pressing

HLW - High-Leve1 Waste

HTGR - High Temperature Gas-Cooled Reactor

IAEA - International Atomic Energy Agency

ILW - Intermediate-ievel Waste

IMCO - Intergovernmental Maritime Consultative Organization

INEL - Idaho National Engineering Laboratory 
xiii 
NOMENCLATURE (contd)

LANL - Los Alamos National Laboratory

LIAW - Low-Level Aqueous Waste

LLRWPA - Low-Level Radioactive Waste Policy Act

LLW - Low-Level Waste

LMFBR - Liquid Metal Fuel Breeder Reactor

LODC - London Ocean Dumping Convention

LSA - Low Specific Activity

LWR - Light Water Reactor

MPC - Maximum Permissible Concentration

MT - Metric Ton

MTHM - Metric Tons of Heavy Metal

NEA - Nuclear Energy Agency

NRC - Nuclear Regul atory Commission

NTS - Nevada Test site

NWTS - National Waste Terminal storage

OECD - Organization for Economic Cooperation and Development

OWWI - Office of Nuclear Waste Isolation

ORNL - Oak Ridge National Laboratory

PITC - Polymer-Impregnated Tritiated Concrete

PNL - Pacific Northwest Laboratories

PWR - Pressurized Water Reactor

RAMPAC - Radioactive Materials Packaging

RTV - Room-Temperature Vulcanizing

SLB - Shallow-Land Burial
SRL - Savannah River

SRP - Savannah River

TGA - Thermogravimet

TRU - Transuranic

TTC - Transportation

USCG - U.S . Coast Guar

USPO - U. S. Pogt offi

WIPP - Waste Isolation
SR

SR

TG

TR

$\mathrm{TT}$

USC

USP

WIP 


\title{
NOMENCIATURE (cortd)
}

\author{
SRL - Savannah River Laboratory \\ SRP - Savannah River Plant \\ TGA - Thermogravimetric Analysis \\ TRU - Transuranic \\ TTC - Transportation Technology Center \\ USCG - U.S. Coast Guard \\ USPO - U. S. Post office \\ WIPP - Haste Isolation Pilot Plant
}


COMPATIBILITY OF TECHNOLOGIES HITH REGULATIONS

IN THE HASTE MANAGEMENT OF H-3, I-129, C-14, AND $\mathrm{Kr}-85$.

PART I. INITIAL INFORMATION BASE

by

L. E. Trevorrow, G. F. Vandegrift, V. M. Kolba, and M. J. Steindler

\section{ABSTRACT}

This report sumarizes the information base that was collected and reviewed in preparation for carrying out an analysis of the compatibility with regulations of waste management technologies for disposal of $\mathrm{H}-3, \mathrm{I}-129, \mathrm{C}-14$, and $\mathrm{Kr}-85$. Based on the review of this literature, summaries are presented here of waste-form characteristics, packaging, transportation, and disposal methods. Also discussed are regulations that might apply to all operations involved in disposal of the four nuclides, including the processing of irradiated fuel in a fuel reprocessing plant, packaging, storage, transport, and final disposal. The compliance assessment derived from this information is reported in a separate document.

\section{INTRODUCTION}

\section{A. Function of this Report}

Technologies for management of $\mathrm{H}-3, \mathrm{I}-129, \mathrm{C}-14$, and $\mathrm{Kr}-85$ need to be analyzed with respect to their potential for compliance with acceptance criteria and regulations. This report contains the information base that will be used in such an analysis.

Several topics are not included here that may conventionally fall into the general category of airborne waste management. (1) Several nuclides released to the atmosphere, especially at reactor sites, are considered to have such a small impact, mainly because of short half-life, that collection and packaging of the waste are not required. (2) Radon-22.2 is an airborne nuclide that arises in some parts of the nuclear fuel cycle, but it will not be managed by collection and packaging; therefore, this nuclide is not considered here. (3) Particulate solids bearing a number of radioactive nuclides, including actinide elements and semivolatiles, e.g., ruthenium, cesium, and strontium, would also be released into some gaseous streams of an FRP. * Management of particulate solids, however, is not consiciered here. These solids will be collected on High Efficiency Particulate (HEPA) filters whose development, efficiency, and use are considered elsewhere. The IsEPA filters bearing the actinides and semivolatile fission products filtered fzom gaseous streams of the FRP will fall into the class of TRU wastes for which DOE supports a separate program and for which a separate disposal destination will be assigned.

\footnotetext{
* Acronyms used in this report are defined on pp. xi-xii.
} 
Furthermore, although a number of airborne wastes result from operations at variety of facilities of the uranium fuel cycle, e.g., mines, mi $118, U E_{6}$ conversion plants, and fuel-fabrication plants, the four nuclides assigned in the charter of this work are released in significant amounts only at an FRP. For that reason, the operations of the FRP only are discussed here. Although the release of radioiodine at reactors is a matter of concern [MURPHY-1983], it is mainly short-lived I-131 that requires removal from the effluents. Because the half-1ife of I-131 is $8 \mathrm{~d}$, Ling-term management and disposal do not enter into the plans for control of this isotope.

Thus, the nuclides addressed in this study are limited to those that will be carried in gaseous streams and that have sufficiently long half-lives to require storage and disposal. The work is not concerned with short-lived gaseous radionuclides that can be managed by delay beds; furthermore, it is not concerned with particulate solids carried by gaseous streams.

Development of disposal modes for airborne wastes (Kr-85, I-129, H-3, and $\mathrm{C}-14$ ) and also development of regulations and acceptance criteria for such nuclear wastes have been carried out in several unrelated activities. Furthermore, workers engaged in development of disposal modes and ragulations regarding them have pursued similar goals, but from widely different starting positions. On the one hand, the focus of imobilization and waste-form development has been physicochemical behavior of materials and processes, and the orientation of packaging and transportation development has been strangth of materials and the design and mechanical performance of packages. Development of regulations, on the other hand, has centezed on setting limits for radioactivity exposure of the public and workers in the nuclear industry. Because these efforts have been pursued with some degree of independence, it is not obvious whether the contemplated disposal modes can comply with regulations or what disposal aites can accept these wastes. The information summarized in. this report forms the basis for a subsequent effort to characterize the proposed disposal modes, assess their capability for complying with applicable regulations, and recommend changes wherever necessary and possible.

\section{B. Study Plan}

The characteristics of airborne wastes will probably not place then in the categories of wastes that may be destined for deep geologic disposal, i.e., HLW and TRU; therefore, it would be convenient if such wastes were acceptable to some other defined mode of disposal, such as SLB. Much experience on handling LLW and on disposing of it by SLB has accumulated, and much recent atcention has been devoted to improving this disposal mode. The plan of this study is to make a series of tests of the compatibility of conceptual disposal modes with regulations. The first test involves a determination of which airuorne wastes would be acceptable for SLB disposal, based upon nine proposed airborne waste forms* and current packaging concepts. Those waste forms that do not

\footnotetext{
Wine waste forms have been assigned as the current primary candidates: (1) krypton in cylinders, (2) krypton in zeolites, (3) krypton in sputtered metals, (4) iodine on silver sorbents, (5) iodine in barium iodate, (6) carbon in barium carbonate, (7) carbon in calcium carbonate, (8) tritium in concrete, and (9) tritium in wolecular sieves.
} 
seem acceptable for SLB are given a second test of compliance, in which some alteration in waste systems, " use of interim storage, or changes in waste forms and containers is assumed. For any waste forms that are not suitable for SL3, even with these changes, a third test will be made to determine whether current or alternative waste forms and containers would be acceptable in some other disposal mode, including seabed emplacement, deep geologic disposal, and greater confinement disposal. In this sequence of testa, for each airborne nuclide, at the first indication of compliance of a disposal mode with regulations, the testing would go no further, and the disposal mode for this nuclide would then be characterized.

\section{Scope of the Study}

The scope of this study will depend on how far conceptual waste forms are from complying with regulations. If the nine waste forms comply with regulations for SLB, then the s sope will be simply limited to the given waste forms and the SLB disposal mode. At the extreme, the scope would have to be expanded to examine several other disposal modes and, ultimately, regulation changes would have to be recommended. Al though the actual analysis (part II) may not need to proceed as far as this extreme, this infurmation base describus all possible disposal modes for the different waste forms and 1 ists the source of more detailed information on them in case they must be used in the analysis.

The information that is most relevant to the main purpose of this work concerns the physical and chemical properties of the waste forms intended for disposal. Nevertheless, some information on sources of these wastes, primary forms, ${ }^{\dagger}$ collection processes, and immobilization processes is also provided here to furnish a complete picture of the derivation of final forms from primary forms. Although much data are available on the properties of pure compounds (e.g., barium iodate), the final storage forms (e.g., barium iodate incorporated into concrete) have been less thoroughly characterized, and in several cases not quantitatively characterized at all.

Information that would best represent reference concepts (i.e., those most likely to be put into practice) have been collected from literature, expert advice, and experimenters. Information on regulations likely to affect airborne waste disposal, i.e., regulations for (1) LLW disposal modes, (2) other applicable disposal modes, and (3) transportation, have also been collected. Regulatory information has been analyzed to facilitate its use in evaluation of waste form perfo:mance.

From the many options for airborne waste management that have been explored, those few considered by current workers as most likely to be applied were selected for attention. These options include immobilization of $\mathrm{kr}-85$ by ion implantation, by zeolites, and by compression of gas into cylinders; immobilization of I-129 by silver sorbents and by barium iodate incorporated into concrete; immobilization of tritium by concrete and by molecular sieves;

\footnotetext{
*Inclusive of the entice set of steps necessary to accomplish disposal: collection, packaging, transportation, and final emplacement.

'Primary forms are those in which the nuclides appear in plant atreams before collection.
} 
and imobilization of carbon by barium or calciu carbonate incorporated into coticrete. The few other options considered have been 1 imited to concepts that seen most feasible [PROUT]. Furthermore, other elements of airborne waste disposal considered here include container technology and transportation wodes, hal low-land burial, interwediate-depth burial, interim storage, deep-geologic disposal, and seabed emplacement. The regulations considered include those of DOE, EPA, NWTS, KIPP, DOT, and other appropriate sources addressing environmental limits.

The question that will be addressed eventually is whether the physical and chenical properties of the waste forms chosen by developers will be sufficient for the waste-form performance that is either specified or can be inferred from the regulations for handing, transportation, and disposal. Only the physical and chemical properties that are relevant to these questions are included here. Obviously, the properties that will be relevant are those generally related to mobility, e.8., volatility, solubility, and chemical and physical stability. 


\section{PRIMARY WASTE FORMS}

\section{A. Occurrence of Airborne Wastes}

The four nuclides in irradiated nuclear fuels that are the focus of interest in this work, $\mathrm{H}-3, \mathrm{I}-129, \mathrm{C}-14$, and $\mathrm{Kr}-85$, have been referred to commonly as airborne wastes because they are likely to appear in the of '" gas of an air sparge of the dissolver in a conventional Purex fuel-reprocessing flowsheet. In the U.S., the commercial fuel cycle (excepting experimental reactors), the weapons fuel cycle, and the naval propulsion fuel cycle involve irradiated fuels. Reprocessing has been carried out on a regular basis in the latter two fuel cycles; but, except for a few campaigns at the West Valley plant and scattered R\&D activities at national laboratories, the teprocessing of commercial fuels on a routine basis has not been parformed in the U.S.

The four airborne nuclides will be distributed throughout several streams of a nuclear fuel cycle, in pattern that depends on the reactor type and on the reprocessing scheme. This study will focus on a reference system of zircaloy-clad uranium oxide fuels removed from an LWR for reprocessing by the Purex process. Some of the airborne nuclides are produced in cladding and coolent, resulting in releases of relatively small amounts at reactors [NUCLSAF]. Small amuunts of the nuclides may also be released at storage basins, R\&D facilities, and medical facilities, but these releases are not of concern here. The focus of this work is on the problem of managing the major fraction of the nuclides that are freed when irradiated fuels are disintegrated during reprocessing.

\section{B. Composition of the Primary Waste Stream}

Estimates of the composition of the off-gas stream carrying the airborne nuclides in a fuel reprocessing plant have been given in several works [ALTOMARE, DP-CFP-78-121, BLANCETT, BROWN-1978], but these estimates of composition disagree quantitatively. The general scheme for the reprocessing of spent fuel carrying airborme nuclides is shown in Fig. II- 1 . The major components of the gas stream are from the air that is used to sparge the dissolver. The composition of the gas stream will depend on (1) whether some other gas, such as argon, is used to purge the fuel shearing cell [EVANS] and (2) whether the "voloxidation"* operation is used to remove tritium from the fue 1 be fore dissolution.

\footnotetext{
*Defined as the oxidation of chopped fuel to convert elemental tritium to tritium oxide, which is then fixed on a desiccant. The objective of this operation is to prevent dispersion of the tritium in the relutively large volumes of dissolver solution.
} 


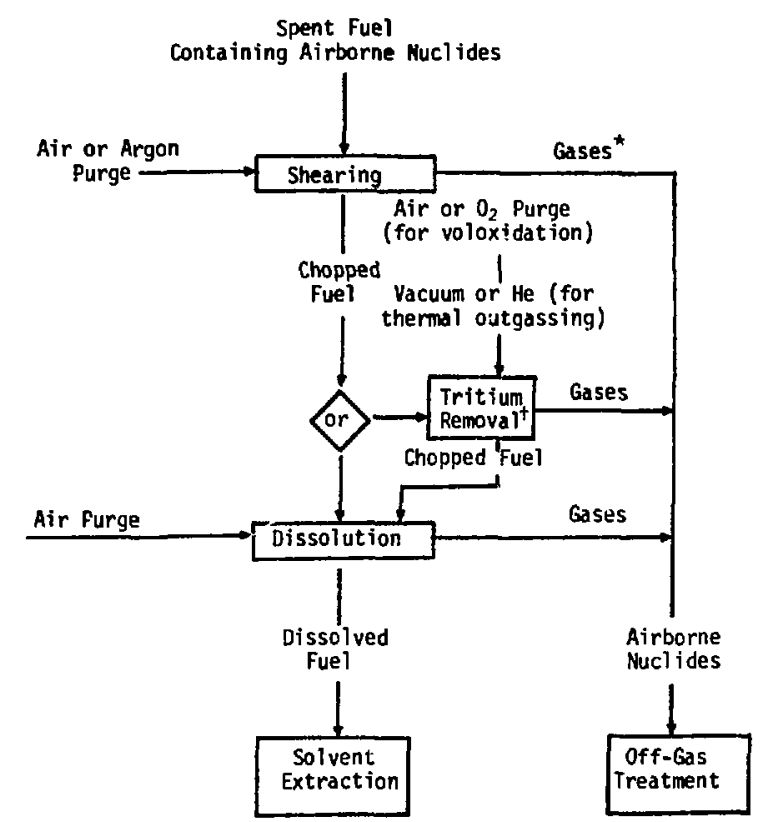

Fig. II : Generic Flow Scheme for Airborne Nuclides in Fuel-Reprocessing Operations

\footnotetext{
* Purge 8as: large fraction of noble gas inventory, amell frection of tritium imventrory.

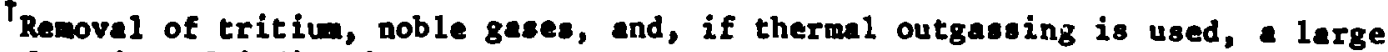
fraction of iodine imventory.
} 


\section{TECHNOLOGIES OF AIRBORNE WASTE FORMS}

In this section, the technologies of waste management for the four nuclides of interest are summarized. This summary includes information on the radioactivities of the four nuclides, methods for their collection from FRP streams and subsequent immobilization, and characteristict of the final waste form. Since many of the final waste forms involve a concrete matrix, a short review of pertinent properties of concrete is included.

\section{A. Technology of Krypton Waste Forms}

\section{Decay Characteristics of Krypton-85}

Krypton-85 has a half-1 ife of radioactive decay of $10.72 \mathrm{y}$. It decays by $R^{-}$emission, with a $514-\mathrm{KeV} Y$ ray associated with the less intense $B^{-}$particles (Table III-1); $\mathrm{Kr}-85$ decay produces a heat output of $1.50 \times 10^{-3}$ $\mathrm{W} / \mathrm{Ci}=5.88 \times 10^{-1} \mathrm{~W} / \mathrm{g} \mathrm{Kr}-85$. Because $\mathrm{Kr}-85$ wil! be only about $6 \mathrm{z}$ of the $\mathrm{Kr}$ collected frow a reprocessing plant's air streams, its specific activity of $393 \mathrm{Ci} / \mathrm{g} \mathrm{Kr}-85$ will be diluted to $24 \mathrm{Ci} / \mathrm{g} \mathrm{Kr}$.

Table III-1. Characteristics of the Radioactive Decay of Kr-85 [MARTIN]

\begin{tabular}{|c|c|c|c|}
\hline $\begin{array}{l}\text { Radiation } \\
\text { Type }\end{array}$ & $\begin{array}{c}\text { Energy, } \\
\text { keV }\end{array}$ & Intensity & $\Delta(g-r a d / \mu C i-h)^{a}$ \\
\hline${ }_{1}^{B_{1}^{-}} \underset{\max }{\max }$ & $\begin{aligned} 173 & \pm 2 \\
47.5 & \pm 0.6\end{aligned}$ & $0.43 \pm 0.01$ & 0.0004 \\
\hline$B_{2}^{-\max }$ & $\begin{array}{c}687 \pm 2 \\
251.4 \pm 0.8\end{array}$ & $99.57 \pm 0.01$ & 0.533 \\
\hline Total $\beta^{-}$avg & $250.5 \pm 0.8$ & $100.000 \pm 0.015$ & 0.534 \\
\hline$r_{1}$ & $513.99 \pm 0.01$ & $0.43 \pm 0.01$ & 0.0047 \\
\hline Total $\underset{i}{\sum\left(\Delta_{i}\right)}$ & $-\infty$ & -- & 0.538 \\
\hline
\end{tabular}

ane $\mathrm{g}-\mathrm{rad} / \mathrm{uCi}-\mathrm{h}$ is equivalent to $2.78 \times 10^{-3} \mathrm{w} / \mathrm{Ci}$. For an infinite, homogeneous medium in which a source is uniformly dispersed with a concentration of $1 \mu \mathrm{Ci}-\mathrm{h} / \mathrm{g}, \Delta$ gives the absorbed dose in rads. For each radiation type $i$,

$$
\Delta_{i}=0.00213 I_{i} \times E_{i}
$$

where $I_{i}=$ intensity of $i$ and $E_{i}=$ energy of $i$. The factor 0.00213 is the conversion factor for $\mathrm{keV} / \mathrm{disintegration} \mathrm{to} \mathrm{grad} / \mu \mathrm{Ci}-\mathrm{h}$. The equilibrium absorbed dose, Deq, in rads equals $C_{85} 5_{K r} \times \Sigma \Delta_{i}$, where $\mathrm{C}_{85} \mathrm{Kr}$ is concentration in units of $\mu \mathrm{Ci}-\mathrm{h} / \mathrm{g}$. 


\section{Collection of Krypton}

For collection of krypton-85, two processes are currently receiving most attention [PENCE-1981A]: fluorocarbon absorption and cryogenic distillation. Collection of noble gases by adsorption on inorganic solids has been investigated on a laboratory scale, but is not developed to the extent of the collection processes named above. It has received serious attention for application to cleanup of fuel-reprocessing off-gases only relatively recently [PENCE-1981B, MONSON, RUTHVEN]. Cryogenic distillation has been judged the most advanced collection technology [PENCE-1981A, MONSON, BENEDICT-1979] . Absorption by fluorocarbon has surcessfully passed pilot-scale tests in the U.S. for scrubbing krypton from a gas atream [MERRIMAN-1982]. Purification of the stripper product, however, inas not been developed. Cryogenic distillation has been in use at the Idaho Chemical Processing Plant since the mid-1960s, although in a system that was not designed for quantitative removal of krypton. This process has been the subject of considerable development work in Eurcpean laboratories [VON AMMON-1978, -1980, -1981, -1983], particularly in Gerriany and Belgium, and it will be demonstrated on a small plant for the first time at the Tokai Mura reprocessing plant in Japan [PENCE-1981A]. Al though the Tokai Mura Plant and U.S. studies [BROWN-1978, DOE/EIS-0046D, MELLINGER] have selected cryogenic distillation as the reference process for noble gas collection, a substantial amount of large-scale development on noble gas collection in the U.S. has involved the process of absorption in liquid fluorocarbons. The cryogenic distillation technologies in the Federal Republic of Germany and Belgium can be obtained in the U.S. through international waste management exchange agreements [CHRISTIAN].

Noble gas collection technology is judged to be ready for testing in a large-scale plant in long-term, fully-simulated conditions.

\section{a. Pretreatment of Primary Gas Stream}

A11 three collection processes are said [PENCE-1981A] to require thorough pretreatment of the off-gas stream in preparation for application of krypton collection processes. The pretreatment is applied to remove particulate solids, a major part of the $\mathrm{NO}_{x}$ [VON AMON-1983], semivolatile fission products (ruthenium), water, iodine, $\mathrm{CO}_{2}$, and methane. All the noble gas collection processes require reduction of water vapor in the gas stream to about $1 \mathrm{ppm}$ [PENCE-1981A]. The major part of the water can be removed by a condenser and the residual can be cleaned up by solid inorganic desiccents, e.g., molecular sieves. The major portion of $\mathrm{NO}_{\mathbf{X}}$ is expected [PENCE-1981A] to be removed by an aqueous absorption column and the remaining 10-20\% in the DOG stream would be removed by (1) reaction with ammonia on a synthetic mordenite catalyst or (2) by reaction with hydrogen on a noble metal catalyst. The choice between these two pretreatment processes will depend on which collection process is to be used. For example, if cryogenic distillation is to be used, the destruction of $\mathrm{NO}_{\mathbf{x}}$ by hydrogen is preferred because a slight excess of hydrogen removes oxygen frim the system, thus avoiding the formation and collection of ozone and its accoupanying explosion hazard. Studies have been aimed at determining the optimal. hydrogen concentration and catalyst [VON AMMON-1980]. On the other hand, if krypton is to be collected by liquid absorption or by adsorption on inorganic solids, then there is no reason to 
enploy hydrogen for its secondary benefit of oxygen remova?; instead, the reaction involving ammonia and mordenite can be used for $\mathrm{NO}_{\mathbf{x}}$ destruction. Recent reports [BRUGGEMAN-1979] on the effectiveness of the ammonia reaction, however, seem to indicate that it is not completeiy without uncertainties. For example, some reduction in performance of the catalyst attributed to high catalyst bed temperatures was observed in pilot-scale studies. Furthermore, catalyst efficiency seems to be affectec by excessive moisture concentration in the gas stream, making control of moisture content critical.

The order of pretreatment operations is important and depends on which collection process is to be used [PENCE-1981A] for the various gas streams. It is suggested [PENCE-1981A] that, if the platinum-catalyzed hydrogen reaction is used to remove residual $\mathrm{NO}_{\mathbf{x}}$, then iodine removal should precede $\mathrm{NO}_{x}$ removal to prevent iodine poisoning of the platinum catalyst. Furthermore, if alkaline-earth hydroxide hydrates are used to remove ${ }^{14} \mathrm{CO}_{2}$, then this operation should precedse the water removal by adsorbents. If $\mathrm{No}_{\mathbf{x}}$ destruction is done by the mordenite-catalyzed reaction with ammonia, the iodine-removal reaction would be placed downstream of the $\mathrm{NO}_{\mathbf{x}}$ destructor, which removes ruthenium before the iodine is collected and avoids interference of ruthenium with iodine removal.

\section{b. Cryogenic Distillation}

In a typical flow scheme (Fig. III-1) for the cryogenic distillation process, a three-component system of krypton, xenon, and nitrogen is compressed to $500-800 \mathrm{kPa}$ and cooled to about -140 to $-150^{\circ} \mathrm{C}$ before injection at the midpoint of a column packed with sieve plates or other appropriate surface [PENCE-1981A]. Some of the nitrogen is cooled to condensation at the top of the column by a liquid-nitrogen-cooled heat exchanger, causing a downflow of liquid nitrogen inside the column. Krypton and xenon are absor bed in the condensed nitrogen and are collected in the bottom of the column. The condensed 1 iquid at the bottom of the column is heated to create a reflux. The temperature profile in the column must be controlled to prevent freezing of xenon and resultant plugging. Krypton and xenon are separated in a subsequent rectification column, operated at a pressure of $300 \mathrm{kPa}$; separation would be carried out as a batch operation. It has been suggested [KLETT-1981] that, if krypton is to be stored as a compressed gas in cylinders, then separation of xenon may not be worthwhile. To avoid problems following from the freezing of xenon, one scheme [PENCE-1981A] removes the xenon by freezing it on a chilled surface $\left(\mathrm{fp},-112^{\circ} \mathrm{C}\right)$, before it enters the primary column. In the Tokai Mura Plant, xenon will be removed with a silica gel bed at $-168^{\circ} \mathrm{C}$.

A cryogenic process using liquid argon as the solvent for krypton and xenon absorption is planned for study at Fontenay-aty-Roses. This process has the same pretreatment requirements as the nitrogen solvent process, but problems caused by freezing of xenon are eliminated, 0zone explosion limits in argon, however, may be too low for safety [PENZHORN-1981].

In pilot-plant studies, the DF for krypton removal from simulated off-gas streams was $10^{2}-10^{3}$, which is greater than the anticipated need for regulatory compliance. The Karlsruhe facility has supported a major effort on development of cryogenic distillation for removal of krypton from 


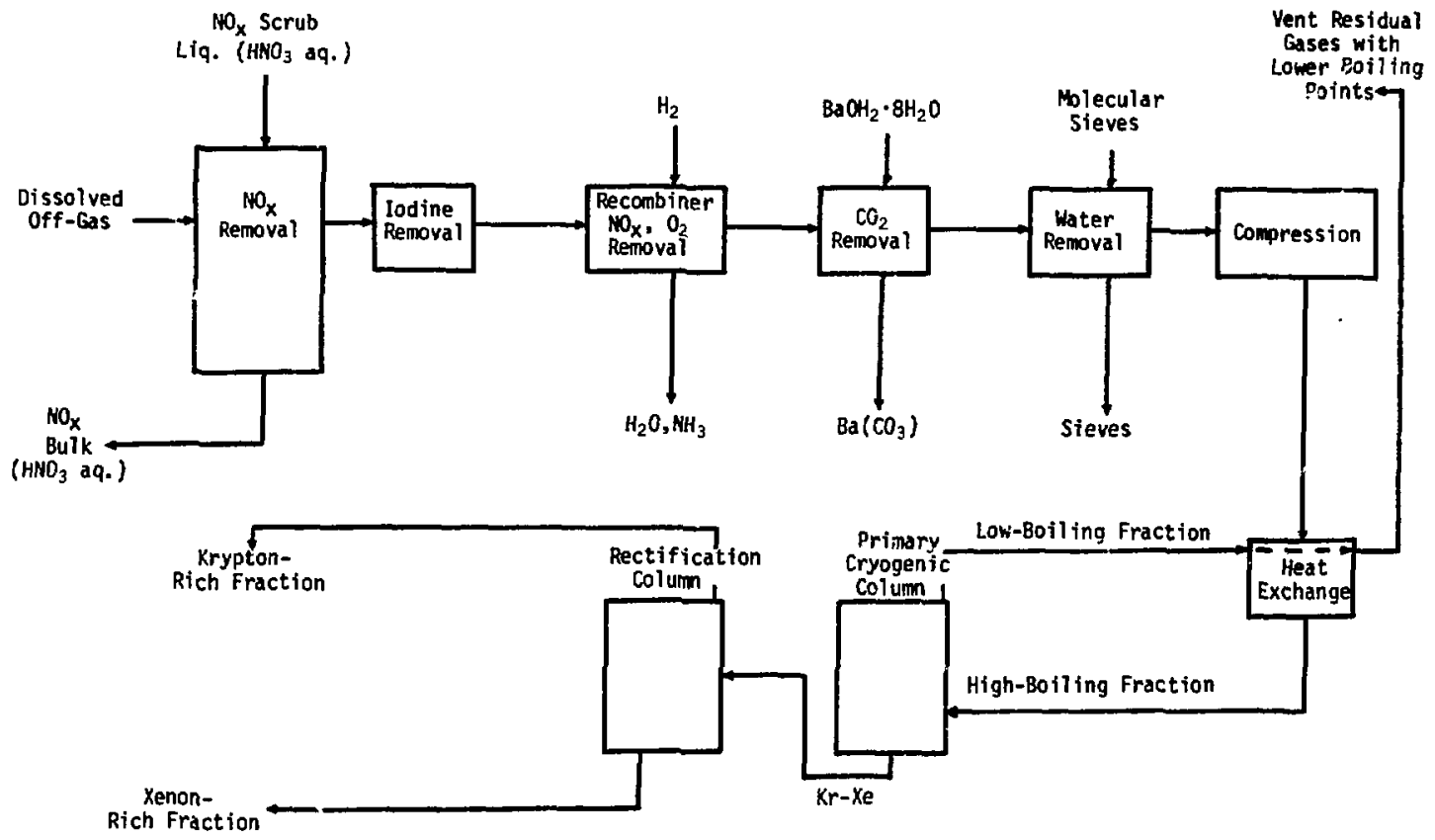

Fig. III-1. Flow Scheme for Collection of $\mathrm{Kr}$ by Cryogenic Distillation (derived from [PENCE-1981A])

fue1-reprocessing gases [VON AMON-1978, -1981]. None of the development projects has been operated for long periods of time in a highly radioactive environment; thus, specifications for actual service have not been well defined [PENCE-1981A]. The Belgian pilot planti has been operated for $10,000 \mathrm{~h}$ [CHRISTIAN].

\section{c. Liquid Absorption}

Experimental investigation of liquid absorption for collection of fission-product noble gases began at the Oak Ridge Gaseous Diffusion Plant in 1967. Pilot-scale testing of the effects of various parameters, including tests with radioactive isotopes $(\mathrm{Kr}-85, \mathrm{Xe}-133$, and $\mathrm{I}-131), \mathrm{CO}_{2}, \mathrm{NO}_{2}, \mathrm{~N}_{2} \mathrm{O}$, $\mathrm{NO}$, and $\mathrm{H}_{2} \mathrm{O}$, have been completed. The liquid absorption method is based on exploiting differences in solubility between the noble gases and other constituents of the off-gas streams in fluorocarbon solvents. The reference solvent is dichlorodifluoromethane, $\mathrm{CCl}_{2} \mathrm{~F}_{2}$. Demonstrated efficiencies [MERRIMAN1980] for removal of $\mathrm{Kr}$ and $\mathrm{Xe}$ from various carrier streams such as $\mathrm{N}_{2}, \mathrm{Ar}$, He, and $\mathrm{H}_{2}$ are said to be $99.9 \%$. It is also claimed that liquid absorption could not only remove $14 \mathrm{CO}_{2}$ from off-gas streams, but also serve as a "backup" syatem for iodine collection [STEPHENSON-1976].

Initial pilot-scale work [STEPHENSON-1976] involved three

coluwn: (1) an absorber column for the main separation of noble gases from bulk gea carrier, (2) a fractional stripper column for removal of the 
lower-boiling carrier gas from the solvent, and (3) a final stripper for removal of all remaining gas from the solvent, which is to be recycled to tiue absorber column. Depending on the carrier gas composition, the recycled solvent may have to be purified in a plant by removing the less volatile constituents such as $\mathrm{NO}_{\mathrm{x}}$ and $\mathrm{I}_{2}$; solvent purification has not been developed [CHRISTIAN]. In later work, a single column was designed, built, and tested; this column is intended to carry out, through control of local temperatures and pressures, all three functions of the original three columns (Fig. III-2). The combination column, requiring less equipment and instrumentation than the single one, is expected to offer operational simplicity and economic advantages. The feasibility of the column is reported to have been established in testing [MERRIMAN-1980].

The purity of the krypton produced by the liquid absorption process can be adjusted to values $>90 \%$, depending on the use of subsequent steps involving cryogenic trapping and solid sorbents to remove fluorocarbon, $\mathrm{CO}_{2}$, and xenon [LITTLE, MERRIMAN-1980].

\section{d. Adsorption on Solids}

The order of pretreatment operations for removal of $\mathrm{NO}_{\mathrm{x}}$, iodine, water, and $\mathrm{CO}_{2}$ before krypton adsorption (Fig. III-3) is similar to that recomended for pretreatment preceding the liquid absorption process. After the pretreatment operations, xenon would be removed from the mixture of krypton, kenon, and air at ambient temperature and pressure by adsorption onto a bed of synthetic mordenite, probably silver mordenite [MONSON]. The gas stream that passes through this bed would be cooled to about $-80^{\circ} \mathrm{C}$ and passed through a cooled bed of another type of zeolite, probably hydrogen mordenite [MONSON], which wouid adsorb most of the krypton. Other constituents of the

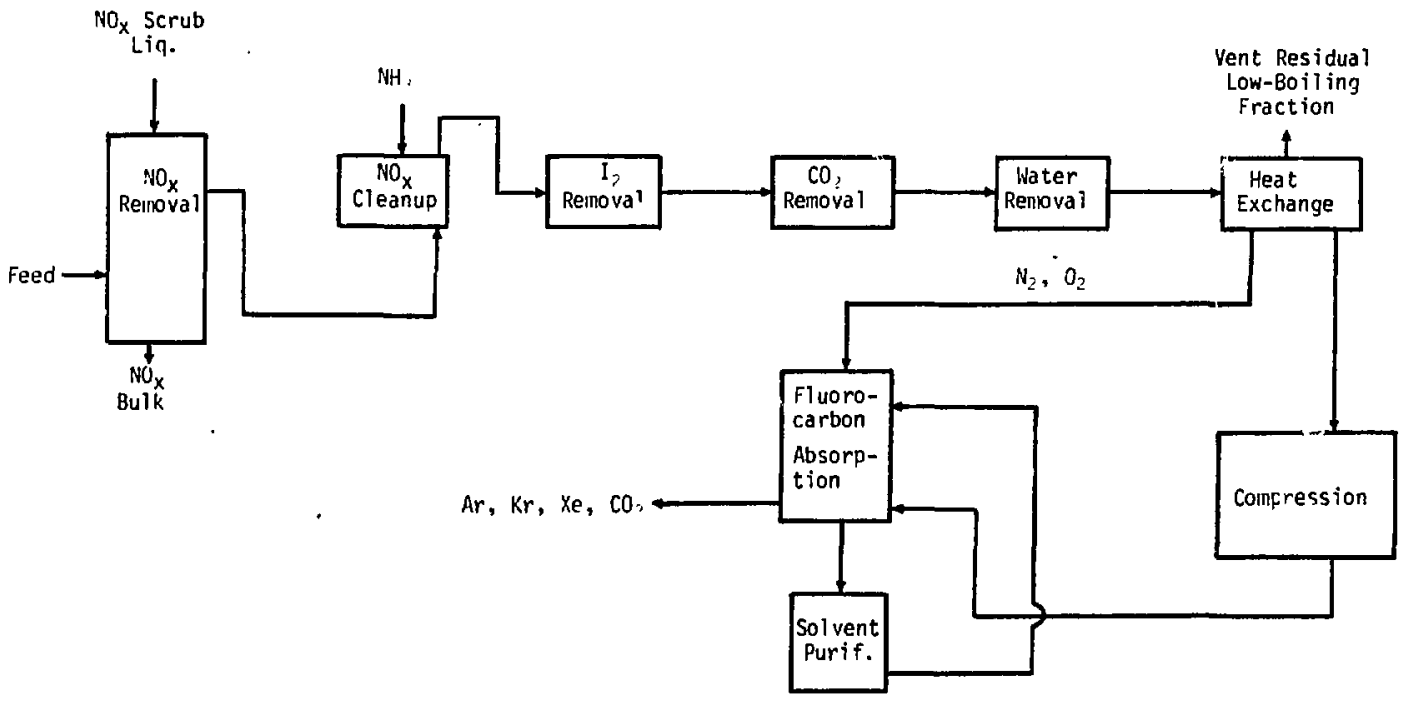

Fig. III-2. Flow Scheme for Collection of $\mathrm{Rr}$ by Liquid Absorption (derived from [PENCE-1981A, MERRIMAN-1980]) 


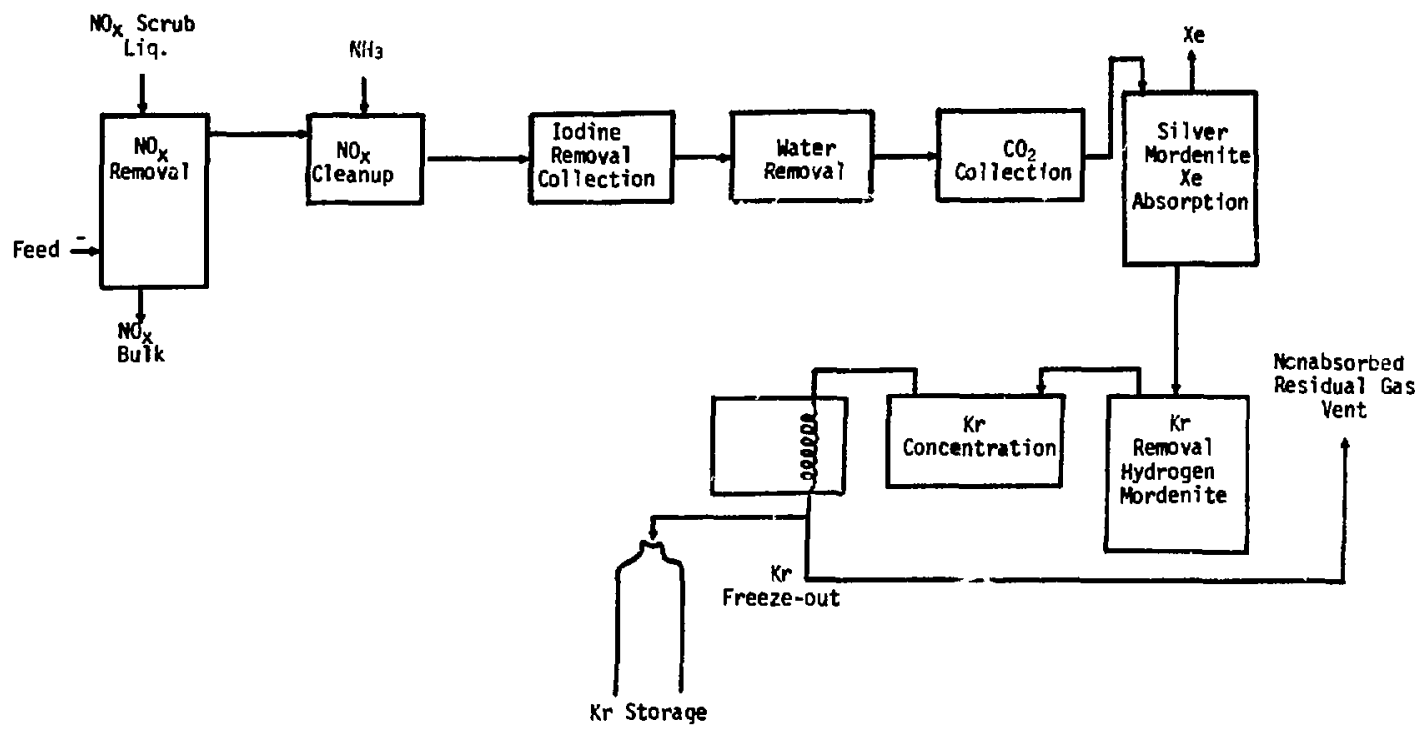

Fig. III-3. Flow Scheme for Collection of $\mathrm{Kr}$ by Adsorption on Solids (from description by [FENCE-1981A])

gas stream would pass through this second column to be vented as decontaminated effluent. The krypton is desorbed from this second column at $60^{\circ} \mathrm{C}$ and rechilled to $-80^{\circ} \mathrm{C}$ before it is passed into a third column for concentration (additional purification) by adsorption onto the same type of zeolite used in the second column. Finally, the krypton would be desorbed from the third column at $60^{\circ} \mathrm{C}$, condensed into a cold trap, and then expanded into cylinders for interim or final storage. Laboratory-scale tests of the adsorption method have shown DF's of at least $4 \times 10^{2}$ for krypton and $4 \times 10^{3}$ for xenon [PENCE1981A]. In a plant, beds of large diameter would be needed; the transfer of heat in large beds has not been addressed. Also, the treatment of krypton that is absorbed onto the xenon bed should be considered [CHRISTIAN].

\section{Immobilization of Krypton}

Although extensive R\&D programs have investigated the production of zeolite and sputtered-metal waste forms, the compressed-gas form is considered by evaluators [MELLINGER] to be the only method that has been demonstrated and is available for immobilization of krypton. The solidification technologies, however, have been sufficiently developed to indicate success may be achieved after additional refinements [CHRISTIAN].

\section{a. Preparation of Compressed-Gas Storage Form}

The operation used to place krypton gas in cylinders for final storuge will depend on the collection process employed. Since cryogenic equipment is involved in the collection operations of both cryogenic distillation and adsorption on solids, the krypton may be condensed by cryogenic methods 
and allowed to expand into cylinders to the desired pressure. If, on the other hand, collection is done by 1 iquid absorption, cryogenic equipment may not be a part of the facility--in which case purified, collected krypton gas will be placed into cylinders by a mechanical compressor [PENCE-1981A, BROWN1978, MERRIMAN-1982]. The cylinders might also be filled without mechanical compression by condensing a measured amount of gas with liquid nitrogen coolant [YAMAYTOT.

\section{b. Characteristics of Compressed Gas Storage Form}

4: : ough $\mathrm{Kr}-85$ has been routinely collected, stored, and shipped in cyli-ders * par* of the operation of the Idaho Chemical Processing Plant

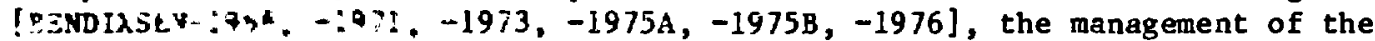

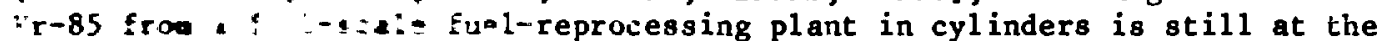
conc- -us. - A 4 yet, there is no generally accepted reference design. In the abs-..et. * " a reference, a thorough description of this mode of

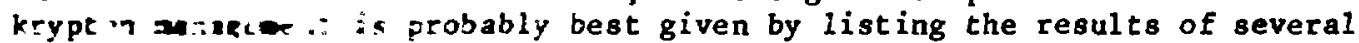
studie, with s drae in :sble III-2. The question of whether the xenon concentracion r'."ld be reduced substantially, to decrease the volume and, therefure, the cost of storage, has been explored in economic analyses. Rlett [XLETT-1981] has concluded that for storage as compressed gas the cost of cryogenic distillation to remove the xenon would justify the economic benefit realized from storage of smaller volumes.

Only certain alloys, Type 316 stainless steel and Nitronic 50, have been found to be suitable for resistance to corrosion by the rubidium produced in decay of Kr-85 [PINCHBACK-1979B, NAGATA]. Experience at the Tokai Mura plant on cylinder storage of $\mathrm{Kr}-85$ will be valuable. Valves have historically been sources of corrosion and leaking problems with storage of even smal1 quantities of $\mathrm{Kr}-85$ [McCLANAHAN].

\section{c. Preparation of Zeolite Waste Form}

In the zeolite waste form, krypton is sorbed into microcavities in the structure of zeolites (crystalline aluminosilicates that contain cavities joined by pores of a characteristic size). The gas is emplaced within cavities, and the zeolite structure is sintered to an amorphous material at high temperature and pressure to seal the krypton in the solid. The rate of leakage of sases from these solids is quite low at room temperature and at temperatures expected for terminal disposal of radioactive krypton (200-350 $\mathrm{C}$ ). Early work in the U.S. involved sodalite, but Penzhorn [PENZHORN-1980A], in the Federal Republic of Germany, found that zeolite $5 \mathrm{~A}$ offers the highest storage capacities and lowest leak rates. Subsequent development in the U.S. has involved zeolite 5A [CHRISTENSEN].

In the process developed in the U.S., dried zeolite $5 \mathrm{~A}$, in the form of small spheres and a powdered-glass binder, is loaded into a capsule, which is then evacuated and heated to $400-700^{\circ} \mathrm{C}$. Contrcl of the moisture content is important and is correlated with the temperature and pressure of encapsulation. Rrypton is introduced into the capsule to pressures of up to $1000 \mathrm{~atm}$, depending on the loading required. This pressure is balanced by a helium pressure on the outside surfaces of the capsule. After a soak time of $0.5-1.0 \mathrm{~h}$, the krypton that has not been incorporated into the solid (about 
Table III-2. Summary of Several Chacacterizations of Storage of Rr as Compressed Gas

\begin{tabular}{|c|c|c|c|c|c|c|c|c|}
\hline & \multirow{3}{*}{\multicolumn{2}{|c|}{ [ ROSTER-1975A] }} & \multirow[b]{3}{*}{ [WARHECKE] } & \multirow[b]{3}{*}{$\begin{array}{l}\text { [BRONA } \\
-1978 \text { ] }\end{array}$} & \multicolumn{4}{|c|}{ [KLETI-1981, ,-1982] } \\
\hline & & & & & \multicolumn{2}{|c|}{ Centrel Repository } & \multicolumn{2}{|c|}{ On-site Repository } \\
\hline & & & & & $\begin{array}{c}\text { RT } \\
\text { Only }\end{array}$ & $\begin{array}{l}1 \mathrm{Kr} / 11 \mathrm{Xe} \\
\text { Hixture }\end{array}$ & $\underset{\text { Only }}{\mathbf{K r}}$ & $\begin{array}{l}1 \mathrm{Kr} / ? 1 \mathrm{xe} \\
\text { Mixture }\end{array}$ \\
\hline $\begin{array}{l}\text { Cylinder } \\
\text { Vol., L }\end{array}$ & 50 & 50 & 50 & 50 & 310 & 310 & 50 & 50 \\
\hline $\begin{array}{l}\text { Peak Pressure, } \\
\text { kFak }\end{array}$ & $3.45 \times 10^{3}$ & $1.38 \times 10^{4}$ & $2.0 \times 10^{4}$ & $3.44 \times 10^{3}$ & $5.2 \times 10^{3}$ & $6.5 \times 10^{3}$ & $1.2 \times 10^{4}$ & $1.5 \times 10^{4}$ \\
\hline $\mathrm{kCi} / \mathrm{cyl} \mathbf{b}$ & 128 & 419 & 340 & 128 & 740 & 123 & 246 & 38.5 \\
\hline Peak temp., "C & 60 & 127 & 200 & 60 & 251 & 58.5 & 220 & 51.5 \\
\hline $\begin{array}{l}\text { Heat generation/ } \\
\text { cy1, }\end{array}$ & 186 & 611 & 534 & 186 & 1060 & 177 & 581 & 92.9 \\
\hline$C y 1 / G N(e)^{-y c}$ & 2.5 & 0.76 & 0.9 & & 0.359 & 2.16 & 1.08 & 6.89 \\
\hline $\begin{array}{l}\text { Dose Rate, } \\
\text { rem/h }\end{array}$ & & & $\begin{array}{l}1.44 \times 10^{4} \\
\text { (nurface) }\end{array}$ & $\begin{array}{l}4.3 \times 10^{2} \\
\text { (at } 3 \mathrm{ft})\end{array}$ & & & & \\
\hline Leak Rate, $\mathbf{z / 5}$ & & & $3.2 \times 10^{-6}$ & & & & & \\
\hline $\mathbf{x}, \mathbf{z}$ & 100 & & 90 & & 100 & 8.3 & 100 & 8.3 \\
\hline $\begin{array}{c}\mathrm{Kr}-85, \mathbf{z} \text { of } \\
\text { totai } \mathrm{xr}\end{array}$ & 6 & & 6.8 & 6 & & 6 & . & 6 \\
\hline$x e, z$ & & & 10 & & & 91.7 & & 91.7 \\
\hline$x_{2}, z$ & & & 0.4 & & & & & \\
\hline$A=, Z$ & & & 0.08 & & & & & \\
\hline $\mathrm{O}_{2}, \mathrm{Pp}$ & & & $\mathbf{1}$ & & & & & \\
\hline $\mathrm{H}_{2} \mathrm{O}, \mathrm{PFa}$ & & & 1 & & & & & \\
\hline $\mathrm{CO}_{2}, \mathrm{PPa}$ & & & 1 & & & & & \\
\hline Cylindex ID, in. & & & & 9 & 11.25 & 11.2 .5 & 9 & \\
\hline $\begin{array}{l}\text { Cslinder } \\
\text { length, in. }\end{array}$ & & & & 52 & 170.4 & 170.4 & 65.5 & \\
\hline $\begin{array}{l}\text { Shieldins } \\
\text { thicknes, in. Pb }\end{array}$ & & & & 3 & & & & \\
\hline Cyl Material & & & & & $3165 s$ & $3168 s$ & $316 s s$ & \\
\hline
\end{tabular}

$1 \mathrm{kPa}=0.00988$ ate (approx. 0.01 ata).

${ }^{b}$ cyl = cylinder.

${ }^{C} \mathrm{GH}(\mathrm{e})-\mathrm{y}=$ Gigawatt (electric) - year. 
65\% of that introduced to the capsule) is recycled. During the process, the zeolite sinters to an amorphous, glassy state. Hot isostatic pressing (HIP) is employed to compact the zeolite and glass powder to a monolithic shape. The capsule containing the molith is sealed into a canister for terminal storage [CHRISTENSEN]. At Exxon-Nuclear Idaho Co., the process has been demonstrated with nonradioactive krypton on a full scale. Also, several hundred Curies of $\mathrm{Kr}-85$ have been encapsulated in a small-scale HIP unit. The samples will be observed for a deiade to determine any long-term effects from rubidium formation or krypton leak rates and waste-form properties [CHRISTIAN].

\section{d. Characteristics of Zeolite Waste Form}

Characteristics of the zeolite $5 \mathrm{~A}$ waste form for storage of krypton-85 are listed in Table III-3. Although earlier work was based on storage of krypton on sotalite and similar solids, it seems to be generally agreed, on the basis of the most recent work, that zeolite $5 \mathrm{~A}$ is the best choice for storage of $\mathrm{Kr}-85$ in this type of solid. It has been concluded [PLUNG] that, for storage in zeolite, prior removal of xenon from the gas seems to be justified by the increased krypton loading that is possible with high krypton concentrations.

A brief test on the effect of irradiation on krypton-loaded zeolites was made. A zeolite sample was irradiated with a $10^{6} \mathrm{~kJ} / \mathrm{kg}$ dose of gamma energy, simulating a 2.7-month storage of $\mathrm{Kr}-85$. The sample contained $37 \mathrm{~cm}^{3}$ (STP)/g of zeolite 5A. In this test, about 0.0097 of the krypton was released [PENZHORN-1980B].

In a test of the effect of water on krypton-loaded zeolites, Penzhorn et al. [PENZHORN-1980B] found "no significant gas desorption" from a $s$ ample containing $37 \mathrm{~cm}^{3}$ (STP) $\mathrm{Kr} / \mathrm{g}$ zeolite $5 \mathrm{~A}$ that was "stored under water for weeks." In a test of the effect of water on krypton-loaded zeolites by Knecht [KNECHT-1981], no release of krypton was observed from samples immersed in water.

\section{e. Preparation of Sputtered-Metal Waste Form}

In the preparation of sputtered-metal waste form, krypton is implanted into a metal surface by electrostatic acceleration of positively charged krypton ions. The surface is also coated with sputtered metal, covering the implanted krypton atoms. This ion implantation and film covering is rapidly alternated until a thick layer $(u l \mathrm{~cm})$ of sputtered metal containing implanted krypton is produced.

This operation is carried out in a vacuum chamber. Krypton is admitted to a previously evacuated chamber and subjected to bombardment by electrons that are accelerated by a potential difference between a heated filament and an anode. This bombardment produces positively charged krypton ions, which are accelerated to a target, negatively charged with respect to the anode, of the metal to be sputtered, In striking the target, the $\mathrm{Kr}^{+}$ ions eject atoms of the target metal, which travel to the substrate surface and deposit there. The substrate, like the target, is negatively charged with respect to the anode in order to attract the $\mathrm{Kr}^{+}$ions, and the ratio of substrate charge to anode charg 3 is selected to maximize the krypton content and to produce net deposit on the substrate. 
Table III-3. Characteristics of Zeolite Waste Form for istorage of Rrypton

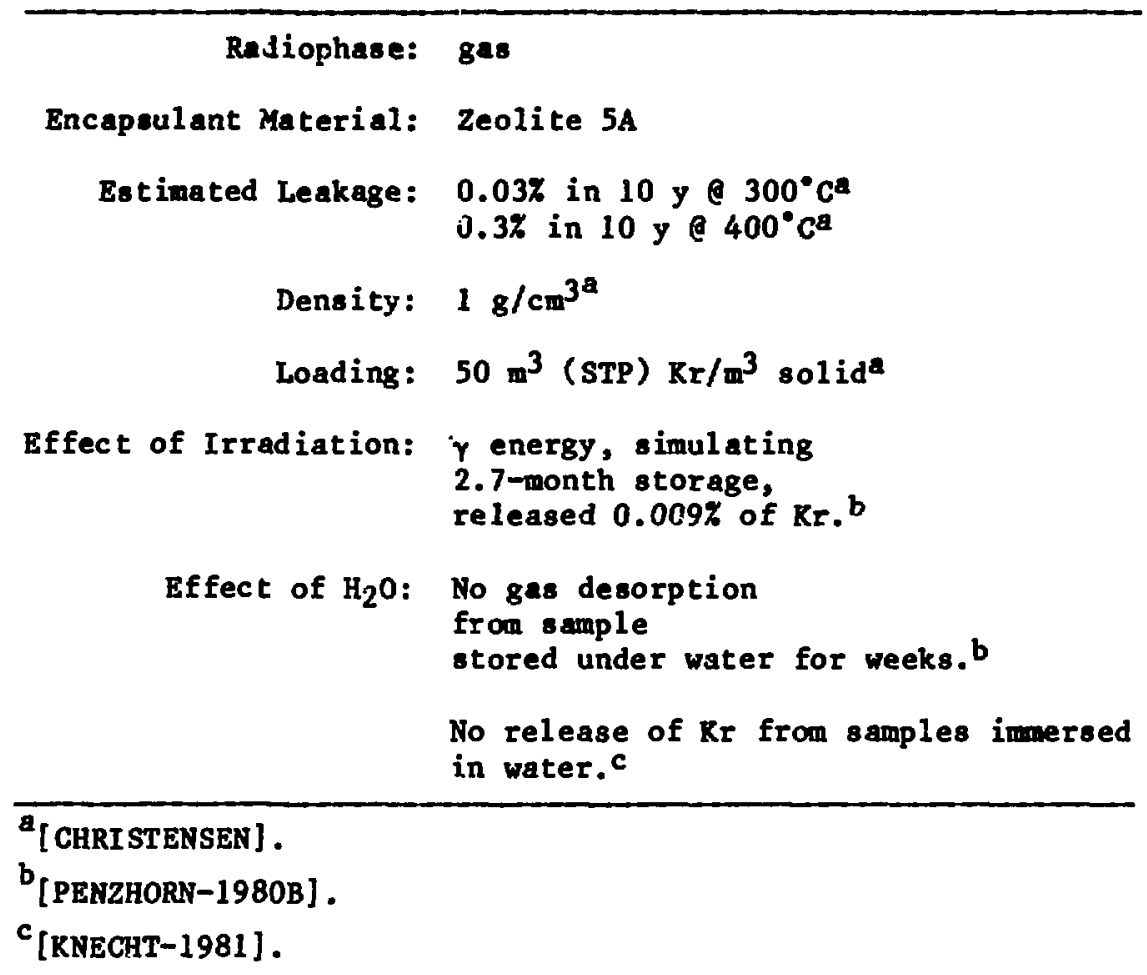

Since a cylindrical chamber, target, and substrate are used in this operation, the waste form will also be cylindrical, i.e., a layer of sputtered metal containing entrapped krypton on the inner surface of a metallic cylinder with a hemispherical, closed bottom. When the sputtered metal layer reaches the desired thickness, the vacuum chamber is detached from the vacuum system, sealed, and treated as the disposal canister.

In a plant-scale concept [PARSONS] of the sputtering method, the substrate is a standard 10-in. SS pipe and pipe cap that is seal-welded to provide encapsulation after deposition is complete. The target is a standard 6-in. steel pipe and pipe cap, with the outer surface initially coated with $1.3 \mathrm{~cm}$ of 79 wt $\bar{z}$ nickel and 21 wt $\%$ lanthanum, a sufficient quantity to result in a $1-\mathrm{cm}$ thick deposit of $\mathrm{Ni}-\mathrm{La}$ on the inner wall of the substrate pipe. The 6-in. target pipe is centered inside the substrate pipe. The annulus between the two pipes contains the appropriate gas phase and a tungsten filament. The substrate, target, and filament are all electrically insulated from one another. A disposal sputtering chamber, wich serves as the primary disposal canister and is not opened after the sputtering process, has been designed and tested on a laboratory scale. It must be tested on the full scale. Romote operations must also be developed. Two 10-Ci samples of Rr-85 have been prepared and three 200-Ci amples will be prepared in FY 1983. These will be observed for a decade to determine long-term storage characteristics [CHRISTIAN]. 


\section{f. Charecteristics of Sputtered-Metal Waste Forn}

Some of the physical characteristics of the sputtered-metal waste form are liated in Table III-4.

Investigations of the behavior of krypton-loaded sputtered metal have shown that, for nickel-lanthanum alloys, atructure change from a glassy to cryataliine state occurs at $350-400^{\circ} \mathrm{C}$ and that higher temperatures $\left(550-800^{\circ} \mathrm{C}\right)$ produce a significant krypton release rate [TINGEY-1982A]. "No major increases in release rates were observed" on exposure of the sputtered material to liquid-phase water at 25 and $90^{\circ} \mathrm{C}$; the results of long-term exposure are expected to become available in the future [LYTLE]. An alloy of nickel, lanthanum, and molybdenum was stable to a temperature of $740^{\circ} \mathrm{C}$, but the molybdenum-containing al loy was considered less desirable because of ito lower trapping rate for krypton. Exposure of the Ni-La-Kr material to oxygen at $320^{\circ} \mathrm{C}$ resulted in a temporary, small increase in krypton release rate; but, after the initial exposure or on removal of the oxygen, the krypton release rate was lower than normal. Evidently, a protective and diffusion-resistant oxide layer forms.

Table III-4. Characteristics of Sputtered Metal Waste Form for Storage of Krypton

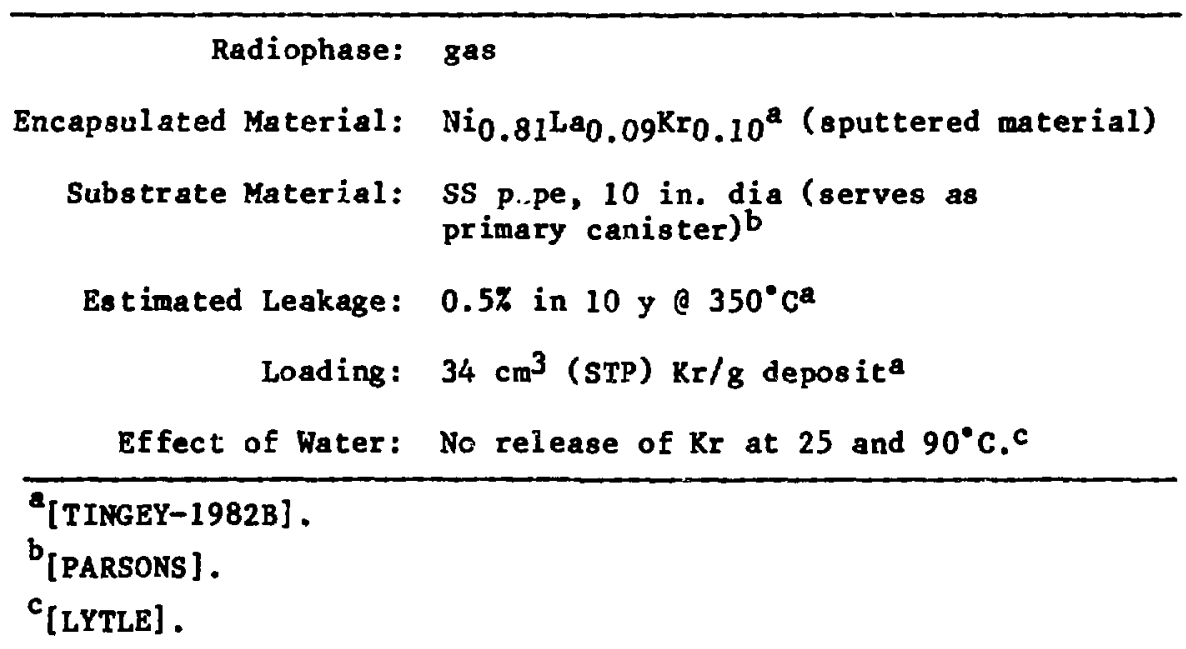

\section{Alternative Rrypton Storage Forms}

In addition to the storage forms described above, a large number of othera have been suggested and have been evaluated according to technical and economic feasibility to varying extents [THAMER-1978,-1979; FOSTER-1975B; KNECHT-1977]. These alternatives are not described in detail here because, at this time, they are considered much less likely to be applied than the three preferred storage forms. They would be seriously reconsidered only in the event that all three torage forms described above prove infeasible. These alternatives include (1) entrapment of krypton in clathrates [STAPLES-1974, CHLECK, MOCK]; (2) storage in porous, underground media as a gas [REIST, TADMOR, KING, 
JACOBS, MUDRA, WINAR]; (3) incorporation of krypton into a grout that is forced underground into horizontal fractures (hydrofracture) created in shale beds [PERETZ] ; (4) storage at subatmospheric pressures in tanks [DUNSTER]; (5) storage of $\mathrm{Kr}-85$ a: a solution in organic liquids [WINAR] or in glass [GRAY$1978,-1979]$. Several other alternatives have been suggested that are judged [THAMER-1978, -1979]-because of cost, lack of development, lack of data, high release rate, or other unfavorable properties of the storage form-to be less attractive than those listed above.

\section{h. Accumulation of Rubidium in Stored $\mathrm{Kr}-85$}

The corrosive effect of the product of $\mathrm{kr}-85$ decay, rubidiun, on the primary container has been a major concern in planning and development for $\mathrm{kr}-85$ storage. Because of this concern, the rubidium corrosion of alloys and possible coatings has been investigated [PINCHBACK-1979A, 1979B; NAGATA; KLETT-1981], which resulted in recommendations for the materials to be used in primary containers for storing $\mathrm{Kr}-85$. The conclusions from corrosion and stress-corrosion tests on several alloys were that 316 SS and Nitronic 50 provide containment for 50-100 y [NAGATA]. The tests also showed that oxygen and. water greatly increased the corrosion rates and should be held to concentrations of $<100 \mathrm{ppm}$. Penzhorn [PENZHORN-1982] suggests that 316 ss will satisfactorily withstand corrosion by rubidium.

The possibility of using corrosion-resistant costings on the interior surface of the primary container is rejected in one report [NAGATA] Investigations of the possibility of using glass coatings were not carried tu conclusion in other work [KLETT-1981]. Data available do not seem to permit definite conclusions on the containment life of packages of $\mathrm{Kr}-85$ stored either as the zeolite or as the sputtered-metal waste form. If the critical factor is the corrosion of the container by rubidium, the corrosion data seem to promise that the integrity of the container is assured for a satisfactory time period. A container lifetime of 50 y (followed by slow release) might accomplish the same result as the proposals of interim storage for $50 \mathrm{y}$ (followed by slow release). Perhaps valve integrity, more than container integrity, will be of greater concern for high-pressure cylinders.

\section{B. Cements as Immobilization Media}

A matrix often proposed for the immobilization of radioactive wastes is concrete prepared from portland cement [LOKKEN]. A brief review of the properties of concrete [HELMUTH] is, therefore, appropriate. As a matter of definition, concrete is a mixture of two components: hydraulic cement, which reacts with water to form a paste that eventually sets and hardens; and aggre-gate, which, when the concrete is used for construction, is mixture of sand and gravel and, when used for the disposal of radioactive waste, is the solid containing the radionuclide [e.g., for encapsulation of I-129, the aggregate

A suggested variation of this alternative involves mixing a zeolite powder containing the $\mathrm{Kr}-85$ with the grout to provide additional entrapment [THAMER-1978]. 
would be $\mathrm{Ba}\left(\mathrm{IO}_{3}\right)_{2}$ or $\mathrm{AgXI}$ ]. Dry cement mixes obtain their cementitious properties by hydration of the constituents. The reaction of water and the major constituents of portland cement are shown below:

$$
\begin{aligned}
& 2(\mathrm{CaO})_{3}\left(\mathrm{SiO}_{2}\right)+6 \mathrm{H}_{2} \mathrm{O} \rightleftharpoons(\mathrm{CaO})_{3}\left(\mathrm{SiO}_{2}\right)_{2} \cdot 3 \mathrm{H}_{2} \mathrm{O}+3 \mathrm{Ca}(\mathrm{OH})_{2} \\
& 2(\mathrm{CaO})_{2}\left(\mathrm{SiO}_{2}\right)+4 \mathrm{H}_{2} \mathrm{O} \rightleftharpoons(\mathrm{CaO})_{3}\left(\mathrm{SiO}_{2}\right)_{2} \cdot 3 \mathrm{H}_{2} \mathrm{O}+\mathrm{Ca}(\mathrm{OH})_{2}
\end{aligned}
$$

Figure III-4 shows a simplied representation of the setting and hardening of portland cement.

Portland (i.e., hydraulic) cements have been specifically designed for construction of underground, marine, and hydraulic structures and consist mostly of mixtures of tri- and dicalcium silicates, with lesser amounts of tricalcium aluminate and ferrite. Calcium chloride is sometimes used to retard or accelerate setting times, depending on its concentration; calcium sulfate also controls setting times and enhances strength. Fly ash, when added to portland cement, enhances its cementitious properties by reacting with the calciun hydroxide formed during hydration. [The compound $\mathrm{Ca}(\mathrm{OH})_{2}$ is non-cementitious and can contribute to long-term instability of the concrete.] Standard portland pozzolanic cement, type I-P, is prepared from $80 \%$ type I portland cement and $20 \% \mathrm{fly}$ ash. High-alumina cements, as the name implies, have higher than typical concentrations of $\mathrm{Al}_{2} \mathrm{O}_{3}$. Al though the hydration product of the high-alumina cements, aluminum hydroxide [1ike $\mathrm{Ca}(\mathrm{OH})_{2}$ ] is non-cementitious, its presence [unlike $\mathrm{Ca}(\mathrm{OH})_{2}$ ] appears to have no effect on the overall, long-term stability of concrete.

The choice of which portland cement to use is based on the special properties of each type of cement, which are as follows:

Type I: when special properties are not required.

Type II: for general use, especially when moderate sulfate resistance or moderate heat of hydration is required.

Type III: for high early strength.

Type IV: for low heat of hydration.

Type V: for high sulfate resistance.

Table III-5 shows the chemical composition of some typical portland and highalumina cements expressed as percentages of various metallic oxides. Table III-6 provides the same basic information in terms of potential compound composition of these cements.

Concretes exposed to seawater, sulfate-containing groundwater, or sewage require sulfate resistance; 80 , it would seem, would concretes designed for long-term storage of radioactive wastes, especially for ocean disposal.

\footnotetext{
*Where AgX is a notocion for silver-exchanged faujasite.
} 

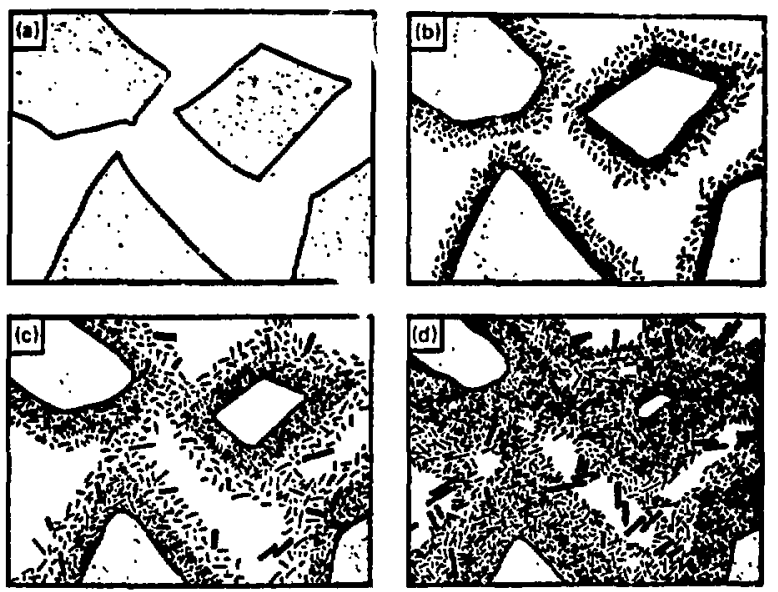

Fig. III-4. Four Stages in the Setting and Hardening of Portland Cement (simplied representation of the sequence of changes): (a) Unreacted clinker grains disperse in water; (b) after a few minutes, hydration products eat into and grow out from the surface of each grain; (c) after a few hours, the coatings of different clinker grains have begun to join up, the gel thus becoming continuous (setting); (d) after a few days, further development of the gel has occurred (hardening). Courtesy of Academic Press Inc. (London) Ltd. [HELMUTH]. 
Table III-5. Chen.cal Composition of Some Typical Cements (expressed as percentages of metallic oxides) [HELMUTH]

\begin{tabular}{|c|c|c|c|c|c|c|c|c|}
\hline & \multicolumn{6}{|c|}{ Composition, wt $x$} & \multirow{2}{*}{$\begin{array}{l}\text { Loss, } \\
\text { wt } z\end{array}$} & \multirow{2}{*}{$\begin{array}{l}\text { Insoluble } \\
\text { residue, wt }\end{array}$} \\
\hline & $\mathrm{SiO}_{2}$ & $\mathrm{Al}_{2} \mathrm{O}_{3}$ & $\mathrm{Fe}_{2} \mathrm{O}_{3}$ & $\mathrm{CaO}$ & $\mathrm{MgO}$ & $\mathrm{SO}_{3}$ & & \\
\hline Type I & 20.9 & 5.2 & 2.3 & 64.0 & 2.8 & 2.9 & 1.0 & 0.2 \\
\hline Type II & 21.7 & 4.7 & 3.6 & 63.6 & 2.9 & 2.4 & 0.8 & 0.4 \\
\hline Type III & 21.3 & 5.1 & 2.3 & 64.9 & 3.0 & 3.1 & 0.8 & 0.2 \\
\hline Type IV & 24.3 & 4.3 & 4.1 & 62.3 & 1.8 & 1.9 & 0.9 & 0.2 \\
\hline Type $v$ & 25.0 & 3.4 & 2.8 & 64.4 & 1.9 & 1.6 & 0.9 & 0.2 \\
\hline $\begin{array}{l}\text { High } \\
\text { alumina }\end{array}$ & 5.3 & 39.8 & 14.6 & 33.5 & 1.3 & 0.4 & 0 & 4.8 \\
\hline
\end{tabular}

Table III-6. Composition of Some Typical Cements ${ }^{a}$ in Terms of the Potential Compounds Formed in the Mix [HELMUTH]

\begin{tabular}{lllrr}
\hline & \multicolumn{4}{c}{ Compound, b wt \% } \\
\cline { 2 - 5 } & $\mathrm{C}_{3} \mathrm{~S}$ & \multicolumn{1}{c}{$\mathrm{C}_{2} \mathrm{~S}$} & \multicolumn{1}{c}{$\mathrm{C}_{3} \mathrm{~A}$} & $\mathrm{C}_{4} \mathrm{AF}$ \\
\hline Type I & 55 & 19 & 10 & 7 \\
Type II & 51 & 24 & 6 & 11 \\
Type III & 56 & 19 & 10 & 7 \\
Type IV & 28 & 49 & 4 & 12 \\
Type V & 38 & 43 & 4 & 9 \\
\hline
\end{tabular}

${ }^{a}$ Calculated by the American Society for Testing and Materials.

${ }^{b} \mathrm{C}_{3} \mathrm{~S}=(\mathrm{CaO})_{3}\left(\mathrm{SiO}_{2}\right) ;$
$\mathrm{C}_{2} \mathrm{~S}=(\mathrm{CaO})_{2}\left(\mathrm{SiO}_{2}\right) ;$
$\mathrm{C}_{3} \mathrm{~A}=(\mathrm{CaO})_{3}\left(\mathrm{Al}_{2} \mathrm{O}_{3}\right) ;$
$\mathrm{C}_{4} \mathrm{AF}=(\mathrm{CaO})_{4}\left(\mathrm{Al}_{2} \mathrm{O}_{3}\right)\left(\mathrm{Fe}_{2} \mathrm{O}_{3}\right)$. 
The density of cured port land cements is $2 \mathrm{~g} / \mathrm{cm}^{3}$ [BAUMEISTER]. Since there should be very little interaction between the cement and the aggregate of the concrete used for waste diaposal, the density of the concrete can be arrived at by use of weight percent concentration of each constituent and its density. For example, for concrete containing $\mathrm{Ba}\left(\mathrm{IO}_{3}\right)_{2} \cdot \mathrm{H}_{2} \mathrm{O}$ with 9.05 wt $\% \mathrm{I}$ $\left[17.7 \mathrm{Ba}\left(\mathrm{IO}_{3}\right)_{2} \cdot \mathrm{H}_{2} \mathrm{O}\right.$, density $\left.=4.66 \mathrm{~g} / \mathrm{cm}^{3}\right]$, the density of the concrete (weight/volume) would be:

density concrete $=\frac{1 \mathrm{~g} \text { concrete }}{\sum(\text { wt fraction constit./density constit. })} \quad$ (III-3)

18 concrete

$=\frac{\left.1 \mathrm{ga} \text { ( } \mathrm{IO}_{3}\right)_{2} \cdot \mathrm{H}_{2} \mathrm{O}}{\left(0.177 \mathrm{~g} \mathrm{Ba}\left(\mathrm{IO}_{3}\right)_{2} \cdot \mathrm{H}_{2} \mathrm{O}\right) \frac{1 \mathrm{~cm}^{3} \mathrm{Ba}}{4.66 \mathrm{Ba}\left(\mathrm{IO}_{3}\right) 2 \cdot \mathrm{H}_{2} \mathrm{O}}+(0.823 \mathrm{~g} \text { cement }) \frac{1 \mathrm{~cm}^{3} \text { cement }}{2.0 \mathrm{~g} \text { cement }}}$ (III-4)

$=2.2 \mathrm{~g} / \mathrm{cm}^{3}$

(III-5)

The addition of an aggregate that has little physical integrity of its own tends to weaken a concrete. This effect is illustrated by the drop in compressive strength of concretes with the addition of increasing amounts of three sludges $(10-40$ wt $Z$ ) that were made to simulate the high-level waste of SRP. These data are presented in Table III-7. It is important to note

Table III-7. Compressive Strength of Concrete Waste Forms [LOKKEN]

\begin{tabular}{|c|c|c|c|c|c|c|c|c|}
\hline \multirow{2}{*}{$\begin{array}{l}\text { Sludge } \\
\text { Type }\end{array}$} & \multirow[b]{2}{*}{ Wt $x$} & \multicolumn{7}{|c|}{ Compressive Strength, $\mathrm{psi}^{a}$} \\
\hline & & & I & II & III & $\mathbf{v}$ & $I-P$ & HAC \\
\hline & 0 & 108 & 824 & 11284 & 13478 & 11898 & 11: 916 & 9311 \\
\hline $\boldsymbol{A}$ & $\begin{array}{l}10 \\
25 \\
40\end{array}$ & & $\begin{array}{l}402 \\
588 \\
464\end{array}$ & $\begin{array}{ll}8 & 243 \\
4 & 630 \\
1 & 259\end{array}$ & $\begin{array}{ll}8 & 694 \\
6 & 180 \\
3 & 054\end{array}$ & $\begin{array}{ll}8 & 829 \\
5 & 620 \\
3 & 054\end{array}$ & $\begin{array}{ll}8 & 296 \\
4 & 472 \\
2 & 380\end{array}$ & $\begin{array}{ll}9 & 574 \\
5 & 792 \\
4 & 363\end{array}$ \\
\hline B & $\begin{array}{l}10 \\
25 \\
40\end{array}$ & & $\begin{array}{l}973 \\
779 \\
932\end{array}$ & $\begin{array}{ll}9 & 045 \\
6 & 412 \\
3 & 352\end{array}$ & $\begin{array}{ll}9 & 321 \\
7 & 230 \\
4 & 736\end{array}$ & $\begin{array}{rr}11 & 159 \\
7 & 158 \\
4 & 234\end{array}$ & $\begin{array}{ll}7 & 692 \\
5 & 855 \\
3 & 311\end{array}$ & $\begin{array}{ll}9 & 624 \\
7 & 158 \\
5 & 884\end{array}$ \\
\hline C & $\begin{array}{l}10 \\
25 \\
40\end{array}$ & $\begin{array}{l}9 \\
5 \\
2\end{array}$ & $\begin{array}{l}313 \\
171 \\
388\end{array}$ & $\begin{array}{ll}7 & 557 \\
4 & 627 \\
2 & 884\end{array}$ & $\begin{array}{ll}7 & 603 \\
5 & 817 \\
3 & 317\end{array}$ & $\begin{array}{ll}8 & 490 \\
4 & 732 \\
2 & 700\end{array}$ & $\begin{array}{ll}7 & 761 \\
4 & 930 \\
3 & 088\end{array}$ & $\begin{array}{ll}8 & 465 \\
6 & 658 \\
3 & 371\end{array}$ \\
\hline
\end{tabular}

$a_{\mathrm{pai}}=6.9 \mathrm{kPa}$.

$b_{\text {Type } A}=50 \mathrm{~mol} \times \mathrm{Fe}(\mathrm{OH})_{3}$ and $50 \mathrm{~mol} \times \mathrm{Al}(\mathrm{OH})_{3}$;

Type $B=40 \mathrm{~mol} \times \mathrm{Fe}(\mathrm{OH})_{3}, 40 \mathrm{~mol} \times \mathrm{Al}(\mathrm{OH})_{3}$, and $20 \mathrm{~mol} \times \mathrm{HgO}$;

Type $\mathrm{C}=50 \mathrm{~mol} \times \mathrm{Fe}(\mathrm{OH})_{3}$ and $50 \mathrm{~mol} \% \mathrm{Mno}$.

CHigh-alumina cement. 
that the different sludge compositions affected each concrete differently; this finding is an indication that the sludge components reacted chemically with the cement components. Thus, the application of these data to a $\mathrm{Ba}\left(\mathrm{IO}_{3}\right)_{2}$ waste form is risky.

The mobility and permeability of water and ionic species are extremely low in concrete. The reasons for this are explainable by the hydration reaction that forms concrete. As concrete begins to gel, the originally continuous pore space becomes a system of discrete capillary cavities surrounded by a continuous gel. Inside the gel formation are extremely small pores ( $\sim 3 \mathrm{~nm}$ ) in which water is trapped. The water trapped inside these pores is greatly affected by the matrix and is, therefore, extremely viscous and tightly bound to the pore walls. The special state of this water is the cause of the extremely low permeability of concrete.

Cements have been studied by many sites as an immobilization medium for low-level wastes. In a survey report, Lokken [LOKKEN] reviews the effects of various parameters on physical properties related to the use of concrete for high-level wastes. The conclusions underline the attributes which make cement a candidate for low-level waste, i.e., low cost, low processing temperatures, processing simplicity, and the requirement for low levels of decay heat and radioactivity to preserve the chemical properties and structual integrity of the monolith. A good general review for understanding the properties of portland cements is provided by Helmuth et al. [HELMUTH].

\section{Technology of Tritium Waste Forms} below.

Methods for the collection and immobilization of tritium are discussed

\section{Decay Characteristics of Tritium}

The radioactive half-1ife of H-3 is $12.35 \mathrm{y}$, and decay ocriurs strictly by $\beta^{-}$emission. These $\beta^{-}$particles have an average energ; of $5.71 \mathrm{keV}$ and maximum energy of $18.6 \mathrm{keV}$. This decay produces a thermal output of $3.39 \times 10^{-5} \mathrm{~W} / \mathrm{Ci}=3.26 \times 10^{-1} \mathrm{~W} / \mathrm{g} \mathrm{H}-3$. Tritium's specific activity of $9.60 \times 10^{3} \mathrm{Ci} / \mathrm{g}$ will be substantially diluted (by a factor of $10^{-6}$ to $10^{-10}$ ) in the water collected from a reprocessing plant's off-gas streams.

\section{Collection of Tritium}

Before discussion of the collection of tritium, it must be mentioned that tritium arising from activities related to fission may never be collected. Several assessments of the environmental significance of the tritium produced in fission-related activities have been made, sone implying that collection may not be economically justified [BRONN-1976, COHEN]. This report does not at tempt to resolve that question; it is concerned only with characterizing 
two tritiun waste forms and a few alternatives that would be used if future regulations make collection and disposal of fission-produced tritium necessary.

The EPA has proposed no ruling specifically addressed to tritium produced in the fission fuel cycle that would be analogous to the rulings on krypton and iodine [40 CFR 190].

If tritium is to be collected fron fission fuels, the forn in which it is available for collection will depend on the type of reactor. In an LMFBR fuel cycle, it will be available mainly as sodium tritide (NaT) in the cold traps used to continually purify the coolant [RENNER]. In an HTGR fuel cycle, a major fraction is expected to appear as water vapor in the off-gas, which is generated fron burning of carbon that is part of the carbide fuels; a smaller fraction will appear in the LLAW from solvent extraction. In conventional Purex processing of LWR fuel, most of the tritium is expected to be available in two forms: tritiated water and discarded cladding hulls. Small fractions of the total amount may be available in elemental form in the offgas fron fuel shearing and dissolution. If recent observations are correct [HENRICi], the mounts of elemental tritium may be so small that installation of a process that would convert the element to water vapor by catalyzed oxidation and combine this vapor with the tritiated water from subsequent operations may not be justified.

Characterization of the distribution of forms and quantities of tritiun in a plant that is reprocessing LWR fuel have varied widely [ALTOMARE, PHILLIPS]. Early observations suggested that most of the tritium in LWR fuel would appear in low-level aqueous waste of FRP [KULLEN]. A recent obsesvation [HENRICH] of the distribution of tritium in irradiated PWR fuel, however, suggests that about $60 \%$ is associated with the zircaloy cladding and most of the remaining 407 is associated with the fuel matrix. Only the latter portion would appear in the LLAH.

Tritium bound in zircaloy cladding hulls is considered to be a form suitable for disposal (see Section III.C.3.c.1.). There are several options for collecting tritium from the fuel matrix: voioxidation or thermal outgassing as a part of the head-end of the processing flowsheet, water recycle to reduce the volume of tritiated aqueous waste, tritium scrub of solvent, or hydrogen isotope separation.

The tritiur removal head-end operations most seriously considered are voloxidation and thermal outgassing. The voloxidation nperation, extenaively investigated by ORNL, involves roasting chopped fuel in the presence of air or oxygen at $450^{\circ} \mathrm{C}$ to drive the airborne waste out of the fuel. If this operatical is used, the tritium in the fuel matrix would be collected as tritiated water on a desiccant. Although voloxidation has been investigated extensiveiy, it cannot be regarded as availeble technology; in fact, there are doubts that it will prove to be technoiogically feasible [MCKAY]. 
Thermal outgassing involves heating chopped fuel at $1100-1500^{\circ} \mathrm{C}$ in a vacuum or helium stream to drive off the airborne wastes. The collection of tritium by this process has not been thoroughly characterized, but experimental demonstrations are now in progress [BURGER-1982A, BRAY]. Both processes endeavor to collect the tritium in a small volume so that dispersal is avoided in the large volume of aqueous solution used for fuel dissolution.

If tritium collection is to be practiced without a head-end tritiumremoval operation, it is generally agreed [HALL, HENRICH, BURGER-1978, MCKAY] that the aqueous plant fluids must be recycled to $1 \mathrm{imit}$ the volume of water containing the tritium from the fuel matrix. According to [MCKAY] a ten-fold reduction in volume of tritiated aqueous FRP wastes could be obtained by recycle. It is asserted [MCKAY, BRUGGEMAN-1980], however, that even with recycle, the volume of tritiated LLAW would be too great to solidify directly and package for terminal storage. Accordingly, the volume of recycled aqueous waste would, in some scheres, be reduced by a factor of 10 through a tritium scrub of solvent [MCKAY, HENRICH] or by a factor of $10^{4}$ or more through separation of hydrogen isotopes. Although several isotope-separation processes have been suggested for this purpose, the process that is currently favored by several organizations is the catalyzed exchange of hydrogen isotopes between hydrogen gas and liquid water. This process is being developed in laboratories in the U.S. [ELLIS], Canada [BUTLER], and Belgium [BRUGGEMAN-1980]. The same reaction, although involving hydrogen gas and steam to prepare water enriched in deuteriun [BENEDICT-1955], was employed on a large scale at the Trail plant in British Columbia in the early 1940s. The technology of this early work has been greatly improved by recent introduction of a hydrophobic cataiyst that permits direct contact of 1 iquid water with the catalyst. Demonstrations have involved a stream of elemental, gaseous H-T mixtures flowing counter-current to a water stream running down through a packed bed of solids bearing the catalyst. An electrolytic cell at the bottom of the column generates the elemental form. Some concepts for large-scale application have proposed that a catalytic recombiner at the top of the column would regenerate the aqueous form [BUTLER, BRUGGEMAN-1980], but experimental setups have not included such a device [ELLIS]. In application to the tritiated liquid waste from FRP, water enriched in tritium could be bled off from the bottom of the electrolysis cell for disposal as tritiated concrete. One conceptual application to FRP [ELLIS] involved bleeding off tritium-enriched hydrogen from the electrolysis cell for disposal as a metallic hydride.

A diagram relating these process options is shown in Fig. III-5. Even though voloxidation and the isotope separation by hydrogen-water exchange over a hydrophobic catalyst cannot be considered proven and available technology, they are at an advanced stage of development compared to thermal outgassing. It seems likely, at any rate, that most of the tritium in irradiated fuels of the LWR type will be collected in cladding hulls and in tritiated water. Disposal of the tritium collected in water is the object of the following review of tritium-immobilization technology. 


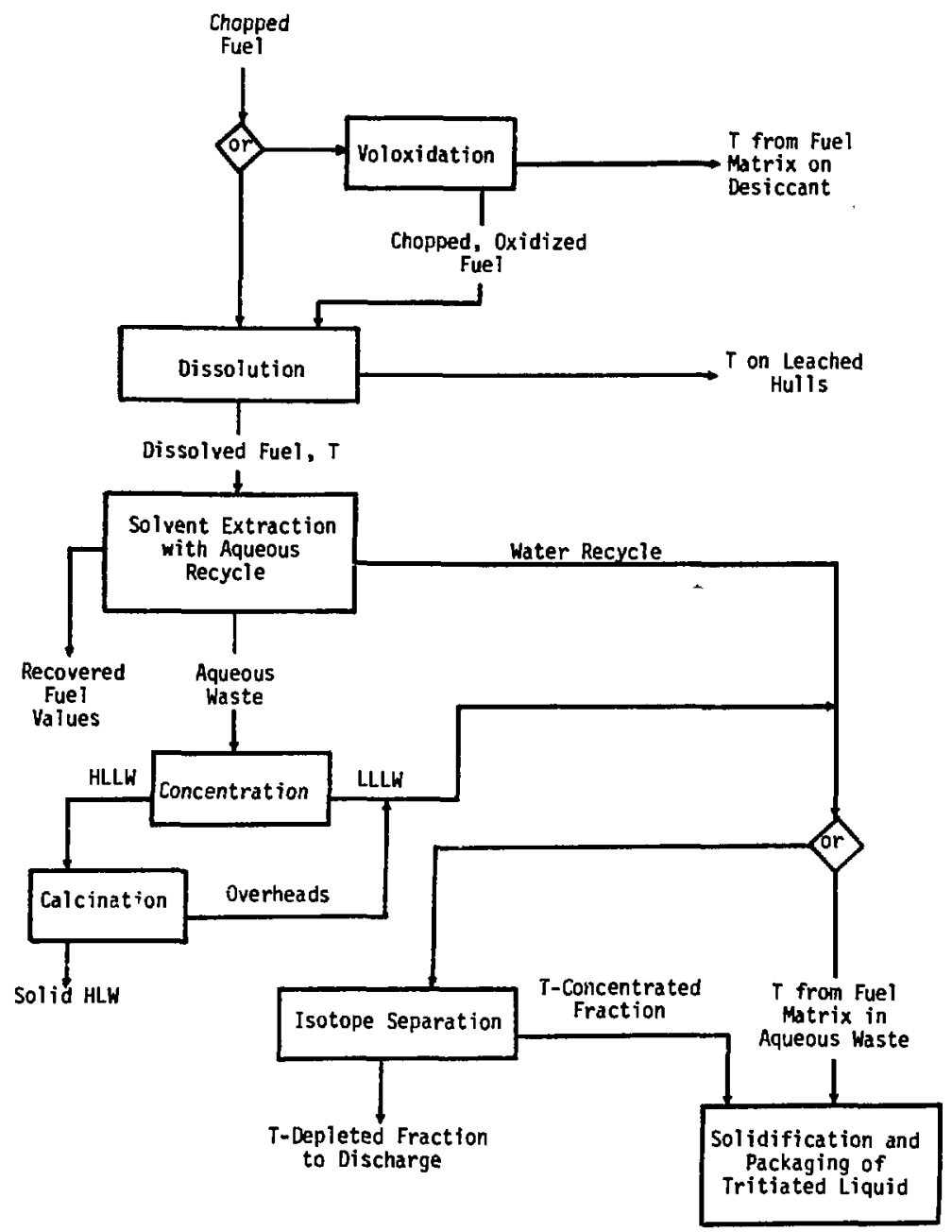

Fig. III-5. Proposed Tritium Collection Operations in Aqueous Fuel Reprocessing

\section{Immobilization of Tritium}

\section{a. Imobilization of Tritium in Concrete}

The incorporation of tritiated water into concrete has been inveatigated by several laboratories during the past decade. Observations of the characteristics of this waste form have been concerned mainly with release of tritium by vaporization and by leaching. Another property of tritiumcontaining concrete that has been studied is the rate of gas formation from radiolyøis [WIENEKE-1979, BIBLER] . 
Leach tests have been made on samples in which variations were made in coating type, cement type, volume/surface ratio, packaging, cement additives, water/cement ratio, ${ }^{7}$ and curing technique. Several additives to increase water loadings have been tried also, including silica gel, vermiculite, and plaster of paris. The comparison of results from different investigators is difficult because of differences in test conditions and expression of results. Nevertheless, the effect of some parameters is so great that general conclusions are obvious. It has been concluded [EMELITY, MCKAY, MATSUZURU] that cement alone is an unsatisfactory matrix for tritium retention. Satisfactory performance of cement forms in leach tests seems to have been obtained only by the aid of a combination of coating and packaging [MERSHAD1977A, -19773 .

The difficulty of retaining tritiated water in solid waste forms is indicated by some observations on water exchange rates. Water exchange rates for aqueous metal ions are extremely dependent on the metal ion, varying over 16 orders of magnitude at $25^{\circ} \mathrm{C}$. The highest rate of water exchange has been measured for alkali metals $\left(410^{9} \mathrm{~s}^{-1}\right)$ and the lowest rate measured for $\mathrm{Rh}^{3+}\left(4 \times 10^{-8} 8^{-1}\right)$. The rates for other metal ions for example $\mathrm{Cr}^{3+}\left(3 \times 10^{-6} \mathrm{~s}^{-1}\right), \mathrm{Co}^{3+}\left(\sim 10^{-1} \mathrm{~s}^{-1}\right), \mathrm{Al}^{3+}\left(\sim 10^{1} \mathrm{~s}^{-1}\right), \mathrm{Fe}^{3+}\left(\sim 10^{2} \mathrm{~s}^{-1}\right), \mathrm{V}^{3+}$ and $\mathrm{VO}^{2+}\left(\sim 10^{3} \mathrm{~s}^{-1}\right), \mathrm{Ni}^{2+}\left(\sim 10^{4} \mathrm{~s}^{-1}\right), \mathrm{Mg}^{2+}\left(\sim 10^{5} \mathrm{~s}^{-1}\right), \mathrm{Mn}^{3+}\left(\sim 10^{6} \mathrm{~s}^{-1}\right)$, and the lanthanides $\left(10^{7}-10^{8} \mathrm{~s}^{-1}\right)$, fall in between these extremes [BASOLO]. The: exchange rate of tritiated water (HTO), however, is not affected by highly variable and relatively low substitution rates. Substitution of tritiated and natural waters occurs by a much faster path--hydrogen-ion-substitution reactions through the making and breaking of hydrogen-bonded water polymers.

The rate constants of the two reactions

$$
\begin{aligned}
& \mathrm{H}_{2} \mathrm{O}+\mathrm{H}_{3} \mathrm{O}^{+} \stackrel{\mathrm{k}_{1}}{\rightleftharpoons} \mathrm{H}_{3} \mathrm{O}^{+}+\mathrm{H}_{2} \mathrm{O} \\
& \mathrm{H}_{2} \mathrm{O}+\mathrm{OH}^{-} \stackrel{\mathrm{O}_{2}}{\rightleftharpoons} \mathrm{OH}^{-}+\mathrm{H}_{2} \mathrm{O}
\end{aligned}
$$

have been estimated by nuclear magnetic resonance (NMR) techniques to be: $k_{1}=8.2 \times 10^{9} \mathrm{M}^{-1} \mathrm{~s}^{-1}$ and $\mathrm{k}_{2}=4.6 \times 10^{9} \mathrm{M}^{-1} \mathrm{~s}^{-1}$. Averaging these two secondoriter rate constants and assuming unit activity for water gives an estimeted first-order rate constant for the reaction

$$
\mathrm{HTO}+\mathrm{H}_{2} \mathrm{O} \stackrel{\mathrm{k}_{3}}{\rightleftharpoons} \mathrm{H}_{2} \mathrm{O}+\mathrm{HTO}
$$

of $k_{3}=6 \times 10^{9} \mathrm{M}^{-1} \mathrm{~s}^{-1}$. Th is rate is higher than can be achieved by any water substitution reaction [GLASEL].

The point of the above discussion is that no chemical mechanism can successfully protect against natural-water/tritiated-water substitution. Tightly binding tritiated water to a chemical matrix will be completely ineffective because of the hydrogen ion transfer mechanism. If a ready diffusion path exists for the transfer of water in and out of the matrix, tritium ion transfer will occur.

\footnotetext{
* The water/cement ratio must be in the range 0.3-0.8 (weight). Below this range, the solid has insufficient strength, and above this ratio a layer of unincorporated water will exiat on the solid.
} 
Cement retains water by mechanisms that are complex and not well understood. Furthermore, the rates of exchange between water contained in cement and water in contact with the cement do not seem to be very well understood [MCKAY]. In portland cenent, water seems to be held in several different physical and chemical forms that are not easily distinguished.

Some of the hydration reactions seem to take place over a long period of time, perhaps years. For practical purposes, the water associated with portland cement can be roughly classified into evaporable and nonevaporable fractions. A block of cement has a characteristic water vapor pressure, which diminishes with curing. At relative humidities that provide a partial pressure higher than this characteristic pressure, the block will absorb water; at relative humidities that provide a lower partial pressure, it will give up water.

The development of a tritiated concrete waste form has included measurements of leach rates on (1) simple tritiated cement with and without several types of coatings [EMELITY, MATSUZURU], (2) polymer impregnateá tritiated concrete (PITC) [COLUMBO-TSDPR], (3) PITC with and without a polyethylene container [WIENEKE-1979], and (4) a cement-plaster combination contained in a multi-walled package [MERSHAD-1977A, -1977B]. Only the last waste form, which will be referred to as the Mound Package, has been shown to have an acceptably low leach rate and has been accepted at a waste-disposal facility (the Nevada Test Site).

The coatings investigated for their ability to aid the retention of tritium in concrete [EMELITY] included asphalt, paints, greases, plastics and waxes. Such coatings reduced the amount or tritium leached in the first year from about $60 \%$ for uncoated concrete to at best about $5 \%$; nevertheless, this simple waste form (blocks of coated concrete) was judged to have an unacceptably high leach rate. A suggested coating [MCKAY] is a layer of cement formed by pouring tritiated cement into a pre-formed cement box; it is asserted that the evaporable water could not be removed from such a package, but this concept has apparently never been tested.

The retention of tritium by FITC has been investigated rather extensively at BNL [COLUMBO-TSDPR], including collaborative observations with workers at Mound and Savannah River Laboratories. The polymer, usually polystyrene, fills the pores in cement, thereby reducing diffusion of water. The final report of the tests at Mound Laboratory [WIENEKE-1979] whowed that the amount of tritium leached by water in the first year was about $1 \%$ for PITC samples contained in polyethylene jackets, but was much higher, 20-50\%, for non-jacketed samples. All of the leach rates of polymer-impregnated cements, with and without polyethylene jackets, were considered to be unacceptably high. *

The waste corm that is currently considered acceptable is the Mound Package--a combinaition of cement, nested containers, and sealants. The Mound Package was developed specificalily to provide disposal for the tritiated wastes arising at the hound Laboratory, some occurring as tritiated water. There seems to be no obvious reason why this package can not be applied to

* Details of the criteria for acceptability are not given; presumably they were determined by negotiations between Mound Laboratory and the disposal facility to which Mound proposed to ship the waste. 
disposing of tritiated water from a fuel reprocessing plant, reduced in volune by one or wore of the processes described in section III.C.2.

The procedure for preparation of the Mound Package is as follows: the polyethylene primary container is loaded with $81 \mathrm{~kg}$ of a $1 / 3$ (volume) mixture of cenent/plaster. The polyethylene prinary container has a capacity of $27 \mathrm{gal}(100 \mathrm{~L})$. About $27 \mathrm{~L}$ of the aqueous waste is then added to the cement-plaster mix. The lid of the polyethylene primary container is sealed with RTV sealant. The polyethylene container, after being placed in an asphalt-coated 30-gal steel drum, is completely covered with non-hardening asphalt. The lid of the 30-gal drum is then sealed with RTV sealant and a bolted ring. The sealed 30-gal drum is centered on a layer of about 4 gal of asphalt in a 55-gal steel drum. The annulus between the two drums is then filled with vermiculite to within a level of about 2 in. below the top of the 30-gal drum. The remaining void is then filled with asphalt, and the 1 id is placed on the 55-gal drum and sealed with RTV sealant and a bolted ring. Details related to this concept are sumirized in Table III-8. A simple cross-sectional diagram of the Hound Package is shown in Fig. III-6.

Table III-8. Characterization of the Mound Package for Disposal of Tritium in Cement

\begin{tabular}{|c|c|c|}
\hline \multicolumn{3}{|l|}{ Packagea } \\
\hline $\begin{array}{l}\text { Primary: } \\
\text { Secondary: } \\
\text { Tertiary: }\end{array}$ & \multicolumn{2}{|c|}{$\begin{array}{l}\text { Polyethylen } \\
\text { Asphalt-cos } \\
55-g a l \text { stee }\end{array}$} \\
\hline Waste Form: a & \multicolumn{2}{|c|}{ Cement/plas } \\
\hline \multicolumn{3}{|l|}{ Weightsa } \\
\hline $\begin{array}{l}\text { Cement-plas } \\
\text { Water: } \\
\text { Vermiculite }\end{array}$ & & $\begin{array}{ll}81 & \mathrm{~kg} \\
27 & \mathrm{~kg} \\
10 & \mathrm{~kg}\end{array}$ \\
\hline
\end{tabular}

Tritium Release Rate: $0.002 \%$ in 87 y (7 half-lives, extrapolated from experimental observations) ${ }^{a}$; $10^{-3}$ after 400 weeks $b$

a[MERSHAD-1977A, -1977B].

b [ LAMBERGER].

Since this Mound Package is the only currently practical technology for disposal of tritiated water in cement, it is considered here as the reference concept. To obtain an even lower release rate, the Mound Laboratory had proposed using PITC rather than the cement-plaster mixture in the Mound Package, but at present nothing other than the cement-plaster form has been used in the actual disposal of wastes [WIENEKE-1982]. Equipment has been assenbled at the Mound Facility to in mbilize their tritiated wastes [CHRISTIAN]. The drume containing solidified Hound wastes are overpacked by piacing 13 or 14 


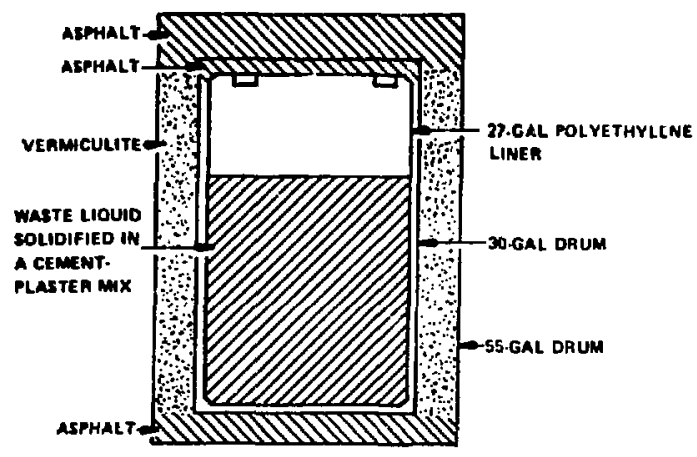

Fig. III-6. Cross Section of the Mound Package for Disposal of Tritiated Waste in a CementPlaster Matrix [MERSHAD1977A]

of them in a container that had been previously used to ship a jet engine in an inert atmosphere. The container is welded shut and sent for SLB [BLAUVELT].

\section{b. Immobilization of Tritium on Molecular Sieves}

Several proposals have been described for trapping tritium, either as the element [LAKNER, TURI] or as tritiated water [BROOTHAERTS, HOLLAND, MCKAY], on molecular sieves. Molecular sieves are comnerically available in the forms of large particles, cylindrical pellets, and sperical beads. It has been suggested that a desiccant for tritiated water storage should have the following properties [MCKAY]: (1) low water vapor pressure, (2) high water content, (3) low solubility, (4) high thermal and radiolytic stability, and (5) low cost. Much of the reported experimental work on reaction of tritium with molecular sieves is concerned not with retention, release, or leakage from the solid to the environment, but with demonstrations of cleanup of gas streams [DELDEBBIO] or with the capacity of the solid for incorporating tritium, hydrogen, or water. The capacity of Type A zeolite for water is 22 wt $z$ when fully saturated as $\mathrm{Na}_{2} \mathrm{O} \cdot \mathrm{Al}_{2} \mathrm{O}_{3} \cdot 2 \mathrm{SiO}_{2} \cdot 4.5 \mathrm{H}_{2} \mathrm{O}$ [MCKAY]

There is much evidence that adsorption by molecular sieves offers an effective collection process for tritium, either as the element or as water. Unanswered, however, is the question of whether molecular sieves also offer a matrix that holds tritium without rapid leakage to the environment. The rate of exchange of hydrogen between water in the adsorbed state and water in the environment is thought to be the primary determinant of the technological feasibility of retention of tritium by desiccant [MCRAY]. A low vapor pressure of water seems to be a necessary, but not sufficient, condition for tritium retention. It is suggested that for tritium retention the 
vapor pressure of water held by the desiccant must be no greater than $10^{-4}$ bar (10 $\mathrm{Pa})$ [MCKAY]. Exchange is thought to be only "loosely related to the vapor pressure," i.e., a low vapor pressure may not indicate a low exchange rate. Equilibrium constants for partitioning of tritium between water on molecular sieves and water in the environment have been measured [ONO]. The results showed that at equilibrium the thermodynamic (i.e., equilibrium) tendencies in this system favor the location of tritiated water on the molecular sieves rather than in the environment surrounding the sieves. The results of this study, however, do not indicate the rate of release of tritiated water adsorbed on molecular sieves. An observation of the rate of appearance of tritium in the environment of a sample of tritiated water held on molecular sieves is needed. Even if they do not provide retention, molecular sieves could be used as a medium for collection and localization of tritium, and some efficient means of packaging, perhaps similar to the Mound Package, would bear the burden of isolating the tritium from the environment.

In the preparation of a tritiated molecular-sieve waste form, Mckay [MCKAY] has recommended that water vapor be contacted with the solid, rather than the solid being immersed in liquid water. One of the possible hazards of manipulation of molecular sieves loaded with tritium is the inhalation of tritium-bearing dust. For this reason, tritium-loaded molecular sieves might best be compressed into monolithic forms, by a process similar to the one proposed for dealing with krypton-loaded molecular sieves [BENEDICT1979, CHRISTENSEN]. Several schemes involve conversion, by catalyzed oxidation, of elemental tritium to H'TO for subsequent adsorption on molecular sieves [BROOTHAERTS, BRUGGEMAN-1980, WITTENBERG, MULLER, BIXEL, SHERWOOD] •

Elemental tritium has a toxicity of about $1 / 30,000$ that of aqueous tritium. Once released to the environment, it converts to aqueous tritium with a conversion time of 6 to $10 \mathrm{y}$ [MASON-1977, -1979].

Encapsulation of the elemental form of tritium by zeolites requires elevated temperatures $\left(350-450^{\circ} \mathrm{c}\right)$ and rather high pressures $(7-14 \times$ $10^{4} \mathrm{kPa}$ ) [LAKNER, FRAENKEL, TURI]. These requirements are disadvantages compared to adsorption of tritiated water vapor onto sieves at ambient conditions. Encapsulation of the elemental form at these high temperatures and pressures would be advantageous if it produces a tritium-encapsulated solid with a much lower leak or exchange rate than that for encapsulated tritiated water. It would have the additional advantage of containing tritium in a less hazardous form. Considering the relative toxicities of elemental and aqueous tritium (given above), a much higher leak rate of elemental tritium encapsulated by zeolites could be tolerated. Some hydrogen molecular-sieve systems may have acceptable thermal stability for applications such as short-term hydrogen fuel storage, but they lack promise for long-term retention of tritium without the aid of secondary containment. For example, at $25^{\circ} \mathrm{C}$, potassium A-type zeolite lost $46 \%$ of its hydrogen load in $45 \mathrm{~h}$, and cesium A-type zeol ite lost $7 \%$ of its hydrogen load in 5 d [FRAENKEL]. In another test [TURI], about 3\% of the hydrogen that had been loaded onto a cesilm zeolite was released in 18 at room temperature. As a test of the retention of hydrogen, this observation [TURI] was flawed because the gas released included 
not only the hydrogen encapsulated in microcavities of the zeolite, but also the hydrogen adsorbed onto surface sites. A thorough assessment of the retention of elemental tritium of hydrogen by zeolites requires more detailed experimentation, but the general trend does not seem favorable for disposal appl icat ion.

Many of the reported schemes involving molecular sieves do not include disposal of them. Rather, the sieves are used only for collection of tritium and are then regenerated for further tritium collection [MULLER, WITTENBERG]; the tritium is removed by heating the sieves and disposed of in some other, unspecified way. If, at saturation, the tritiated water held on molecular sieves is 20-22 wt $\%$, storage of the entire dilute LLAW strean of a Purex reprocessing plant in this manner would involve unacceptably large volumes. Therefore, tritiated water stored on molecular sieves would have to be the product of one or more of the volume-reduction processes discussed in Section III. C.2, i.e., recycle, tritium scrubbing, voloxidation, or isotopic exchange.

Thus, a good deal of attention has been given to use of molecular sieves for their properties in cleanup of gas streams, i.e., their performance as getter for either hydrogen or water and also for their capacity, i.e., the quantity of $\mathrm{H}_{2}$ or $\mathrm{H}_{2} \mathrm{O}$ held by the sieves. Few observations, however, seem to indicate whether they would also perform well as a long-term retainer of tritium. Only experimental work on exchange of tritium between molecular sieves and environmental water will answer that question. A review [MCKAY] of the storage of tritium on solids suggests the following order of merit for the various candidates for matrix materials: (1) inorganic hydrates, * (2) metal hydrides, (3) organic polymers, and (4) cement.

\section{c. Alternative Tritium Immobilization Technologies}

\section{(1) Zirconium Hydride}

The capability of several transition wetals for reacting readily with hydrogen to form stable hydride compounds [MUELLER] and the availability of waste zirconium metal in the LWR fuel cycle ${ }^{\dagger}$ have led to the suggestion that zirconium hydride be used as a waste form for tritium. Investigations of the feasibility of this concept have included experimental observations of suitable conditions for the reaction of zircaloy tubing with hydrogen [SCHEELE-1976] and also of the leaching behavior of zirconium hydride [COLOMBO1977].

Reaction conditions consisting of a temperature of $630^{\circ} \mathrm{C}$ and 1 atm pressure were found capable of producing a high loading of hydrogen in solid zirconium (approaching $\mathrm{Zr} / \mathrm{H}=2$ ) at a practicable rate [SCHEELE-1976].

\footnotetext{
\# category in which molecular sieves is included in this author's discussion. tzircaloy hul ls contain 2987 zirconium.
} 
The quantities of zirconium required to store the tritium from fuel reprocessing will depend on the amount of associated hydrogen and oxygen. As in the case of most other tritium-storage schemes, the airconium hydride concept is feasible only if the volume of tritiated waste water is minimized. Thus, it would best be applied to the product of one of the volune reduction schemes des.ribed in Section III.C.2. For a product with H/Zr ratio of 2 , the quantities of zirconium necessary to hold the hydrogen-tritium mixtures from fuel reprocessing have been estimated, as shown in Table III-9. Comparison of the required quantities of zirconium in this table with the estimated quantities of cladding hulls $\left(3.7 \times 10^{5} \mathrm{~kg} / 1500 \mathrm{MTHM}\right.$, see Table III-9) suggests that, if cladding hulls are to be the sole source of zirconium, then the volume reductions obtainable through voloxidation or through recycle plus isotope separation are necessary.

The results of a limited series of leach tests on zirconium hydride samples are briefly summarized in Table III-10. These results indicate roughly that the leach rate of zirconium hydride is small; however, the reports upon which these results are based lack sufficient details concerning the effects of several parameters that generally affect leach rates.

Several considerations have to be taken into account in an evaluation of the feasibility of storage of tritium as the zirconium hydride. One advantage suggested for this mode of storage is the relatively small space required [SCHEELE-1976]. In addition, it is believed that this waste form would satisfy requirements of noncombustibility [ALTOMARE], although details of its behavior as a function of temperature and gaseous environment have yet to be investigated at realistic conditions. One of the disadvantages of metallic hydrides as a tritium waste form is the necessity for converting all trit$i$ und associated hydrogen to the elemental form. To make this scheme practicable, the tritium would have to be isolated before dispersion in dissolver solution. Another disadvantage is the need to have a hydrogen-tritium mixture free of other contaminants [SCHEELE-1976], e.g., oxygen. If zircaloy hulls are used to fix the tritium, the radioactive properties of the neutronactivation products associated with the hul ls are likely to determine the packaging necessary to meet transportation regulations and acceptance criteria at a disposal facility, e.g., SLB facility.

\section{(2) Organic Compounds}

The incorporation of tritium into organic compounds has been investigated experimentally [FRANZ-1975, -1976; COLOMBO-1974], and evaluated at some length [MCKAY]. Several candidate compounds have been suggested [MCKAY], and experimental work has been done on $s i x$. These compounds included polyacetylene [COLOMBO-1974], tritiated Bakelite, polyacrylonitrile, polystyrene, polyureylene-polymethane copolymer [FRANZ-1975, -1976], and polyvinyl chloride [DIAMOND]. The preparation of polystyrene would require the conversion of tritiated aqueous waste to hydrogen, which would be reacted with polystyrene in a solvent in the presence of a catalyst but in the absence of oxygen; the latter step is taken to discriminate against formation of $\mathrm{T}_{2} 0$. The preparation of the other compounds, however, could be carried out by direct reaction of tritiated water. Results of tests of the thermal stability of several of these polymers, summarized by [MCKAY] in Table III-11, showed that 
Table III-9. Quantities of Zirconium Required to Fix Tritiated Aqueous Waste from Fuel Reprocessing as $\mathrm{ZrH}_{2}$

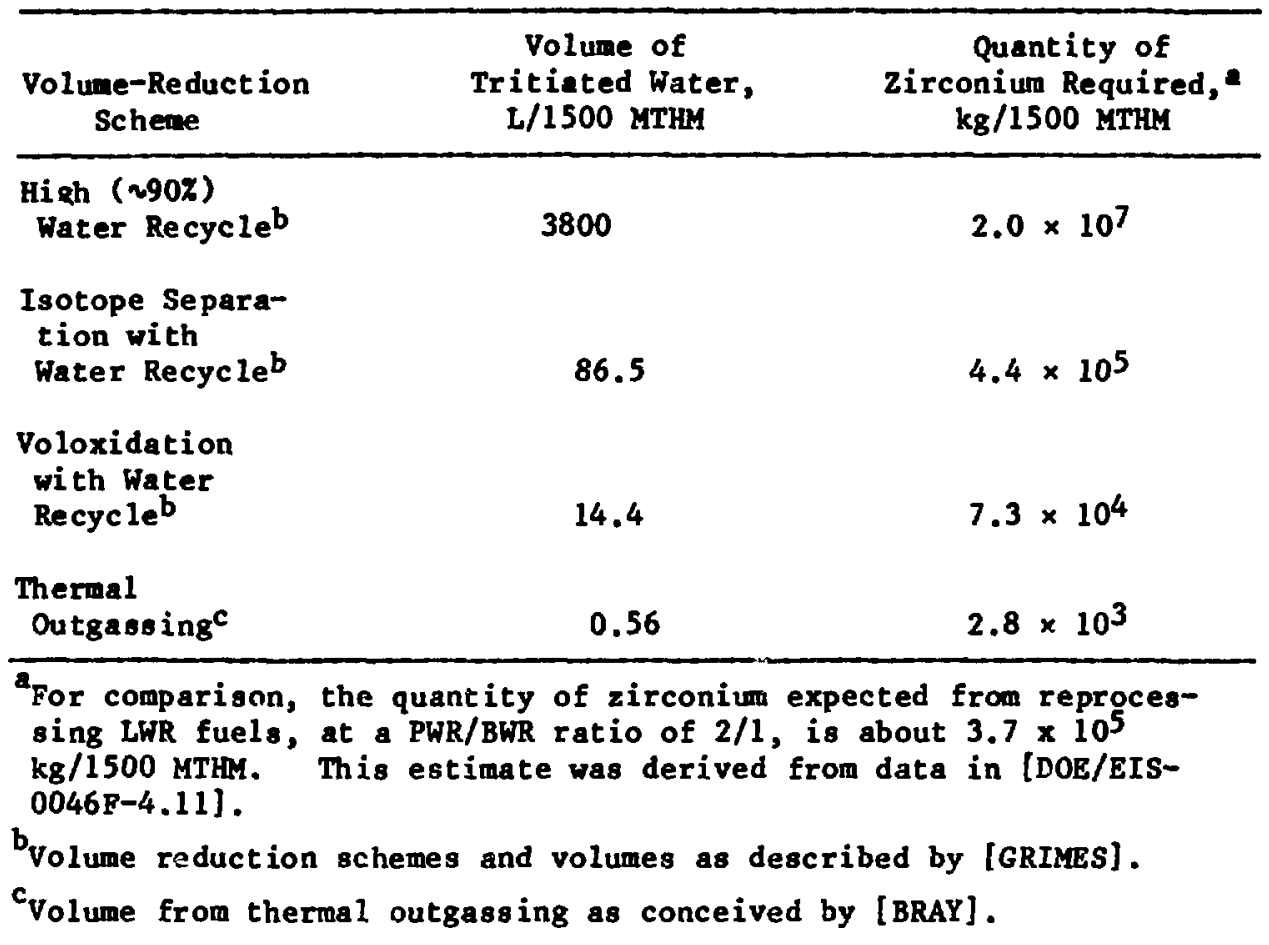

Table III-10. Results of Leach Tests on Tritiated Zirconium Hydride

\begin{tabular}{lcc}
\hline $\begin{array}{c}\text { Leach } \\
\text { Solution }\end{array}$ & Fraction of Tritium Released During Perioda \\
\cline { 2 - 3 } Distil. $\mathrm{H}_{2} \mathrm{O}$ & None detected & $(2.3-6) \times 10^{-5}$ \\
$\mathrm{HCl}(\mathrm{pH}=4)$ & None detected & $1.6 \times 10^{-4}$ \\
$\mathrm{NaOH}(\mathrm{pH}=10)$ & Not measured & $5.5 \times 10^{-4}$ \\
\hline
\end{tabular}

summarized by [MCKAY] from observations reported in [COLOMBO-TSDPR]. 
Table III-11. Thermal Stability of Tritiated Organic Compounds

\begin{tabular}{lc}
\hline \multicolumn{1}{c}{ Compound } & $\begin{array}{c}\text { Thermal } \\
\text { Degradation } \\
\text { Threshold, } \\
\text { c }\end{array}$ \\
\hline Bakelite-type & 130 \\
Polyacrylonitrile & 200 \\
Polyvinylacetate & 150 \\
Polyureylene/polyurethane & 180 \\
Hydrogenated polystyrene & 280 \\
\hline From compilation in [MCKAY].
\end{tabular}

they are generally stable up to about $200^{\circ} \mathrm{C}$, with varying stages of decomposition beginning at temperatures of about $130^{\circ}-300^{\circ} \mathrm{C}$. The thermal stability of these polymers is probably the main point to be considered in assessing their capability for complying with technical criteria in regulations for transport or for terminal storage. Simple leach tests have shown that the leachability of tritium from these solids is slight [MCKAY]. After an initial exposure to water in which 0 to $5 \%$ of the tritium was leached out, the quantity of tritium lost in additional exposure was undetectable in most cases.

Results of leach tests on tritiated polyvinyl chloride [DIAMOND] are not easily compared with the results on the other compounds reported [FRANZ-1975,-1976] and [COLOMBO-1974], but it is clear that leach rates for this compound were quite low; the surface penetration derived from the observations was $70 \AA$ per day. From data in the description of this work [DIAMOND], it is possible to express the leach rate, for a surface/volume ratio of $2-3 \mathrm{~cm}^{-1}$, as a fraction of about $2 \times 10^{-4} / \mathrm{d}$.

Information on the radiation stability of several of these compounds were compiled by McKay [MCKAY] as shown in Table III-12. The G values listed in Table III-12 suggest that radiolytic gas formation rates in these compounds are not likely to be great enough to prohibit their use as storage media.

\section{(3) Other Tritium-Management Options}

Among the many other tritium-management options that have been suggested [BURGER-1974, -1976], two seem to be regarded as feasible. One is the tank storage of tritiated aqueous waste. This concept has not been developed much beyond enumeration of the probable parameters [BROWN-1980] and preliminary cost estimates [ARNOLD, NEA, GRIMES]. The other option, suggested both in U.S. studies [TREVORRON, PERKINS] and in German planning [HARTMANN], is deep-well injection of tritiated aqueous waste. Neither of these options afford the degree of immobilization obtainable by incorporation of tritium 
Table III-12. Radiation Stability of Organic Compounds Proposed as TritiumStorage Forms

\begin{tabular}{lc}
\hline \multicolumn{1}{c}{ Compound } & G Value, a ion/lo0eV \\
\hline Polyacetylene & $0.15\left(\mathrm{H}_{2}\right.$ only) \\
Polyethylene & $2.1-3.9$ \\
Phenol-formaldehyde resins & 0.1 \\
Polyacrylontrile & 0.4 \\
Polyvinylacetate & 1.4 \\
Polystyrene & $0.08,0.03$ \\
\hline
\end{tabular}

arom compilation in [MCKAY].

into chemical compounds, but promise to be capable of delaying the dispersal of tritium to the environment until the radioactivity associated with the waste has been greatly reduced by decay.

D. Technologies of Iodine Waste Forms

\section{Decay Characteristics of I-129-Containing Waste Forms}

Iodine-129 has a half-life of radioactive decay of $1.57 \times 10^{7} \mathrm{y}$ by $B^{-}$and $\gamma$ decay of the energies shown in Table III-13. Data, also presented in this table, show that the thermal output of 129 I is almost equally divided between $B^{-}$and a series of low energy $x$-rays. Table III-14 gives the composition of iodine isotopes expected to be present in the blended fuel of an LMFBR from time of discharge to $10 \mathrm{y}$ after discharge. One year after discharge,

there are significant concentrations of only two iodine isotopes--stable I-127 (24.6 wt $z)$ and I-129 (75.4 wt $z$ ). Table III-15 shows the differences in the amount of these two iodine isotopes produced in different reactor fuels.

Because of its long half-1ife of radioactive decay, I-129 has a low specific activity, $1.77 \times 10^{-4} \mathrm{Ci} / \mathrm{g} \mathrm{I}$. Since the material for disposal is not 100\% I-129, but rather $275 \%$ (based on data presented in Table III-14), the specific activity of iodine as the waste form will be only $1.3 \times 10^{-4} \mathrm{ci} / \mathrm{g} \mathrm{I}$.

Based on the specific activity of I-129 and the energies and intenities of its decay modes (Table III-13), the thermal output of I-129 equals $4.62 \times 10^{-4} \mathrm{~W} / \mathrm{Ci}$ or $8.18 \times 10^{-8} \mathrm{~W} / \mathrm{g}$. Based on the fact that reprocessing waste iodine is only $75 \% \mathrm{I}-129$, the heat release of the iodine would be $6.1 \times$ $10^{-8} \mathrm{~W} / \mathrm{g} \mathrm{I}$. 
Table III-13. Radioactive Decay of I-129, Radiation Types with Their Corresponding Energy, Int unsity, and Energy Emitted per Disintegration [MARTIN].

\begin{tabular}{|c|c|c|c|}
\hline Radiation Type & $\begin{array}{c}\text { Energy, } \\
\text { keV }\end{array}$ & $\underset{\%}{\text { Intensity, }}$ & $\Delta(g-r a d / \mu C i-h) a$ \\
\hline Auger-L & 3.43 & $74 \pm 4$ & 0.0054 \\
\hline $\begin{array}{l}\text { Conversion } \\
\text { Electron-R-1 }\end{array}$ & $5.02 \pm 0.03$ & $79.10 \pm 20$ & 0.0085 \\
\hline Auger $-K$ & 24.6 & $8.8 \pm 1.6$ & 0.0046 \\
\hline $\begin{array}{l}\text { Conversion } \\
\text { Electron-L-1 }\end{array}$ & $34.13 \pm 0.03$ & $10.6 \pm 0.3$ & 0.0077 \\
\hline $\begin{array}{l}\text { Conversion } \\
\text { Electron-M-1 }\end{array}$ & $38.44 \pm 0.03$ & $2.10 \pm 0.10$ & 0.0017 \\
\hline $\begin{array}{l}\text { Conversion } \\
\quad \text { Electron-NOP-1 }\end{array}$ & $39.37 \pm 0.03$ & $0.70 \pm 0.10$ & 0.0006 \\
\hline $\begin{array}{r}\text { B- } \max \\
\text { avg }\end{array}$ & $\begin{array}{r}150 \pm 5 \\
40 \pm 5\end{array}$ & 100 & 0.0852 \\
\hline X-ray $L$ & 4.1 & $8.2 \pm 2.5$ & 0.0007 \\
\hline $\mathrm{X}$-ray Ka2 & $29.4580 \pm 0.0010$ & $20.0 \pm 0.6$ & 0.0126 \\
\hline $\mathrm{X}$-ray Kal & $29.7790 \pm 0.0010$ & $37.1 \pm 0.9$ & 0.0235 \\
\hline $\mathrm{X}$-ray $\mathrm{KB}$ & $\begin{array}{c}33.6 \\
39.58 \pm 0.03\end{array}$ & $\begin{array}{l}13.2 \pm 0.4 \\
7.50 \pm 0.20\end{array}$ & $\begin{array}{l}0.0094 \\
0.0063 \\
\end{array}$ \\
\hline$\underset{\mathbf{i}}{\operatorname{Total}} \underset{\mathbf{i}}{\left(\Sigma \Delta_{i}\right)}$ & - & - & 0.1662 \\
\hline
\end{tabular}

anergy emitted per disintegration in units of $\mathrm{g}-\mathrm{rad} / \mu \mathrm{Ci}-\mathrm{h}$. For an infinite, homogeneous medium in which a source is uniformly dispersed with a concentration of $1 \mu \mathrm{Ci}-\mathrm{h} / \mathrm{g}, \Delta$ gives the absorbed dose in rads. For each radiation type $i$

$$
\Delta_{i}=0.00213 I_{i} \times E_{i}
$$

where $I_{i}=$ intensity of $i$ and $E_{i}=$ energy of $i$. The factor 0.00213 is the conversion factor for $\mathrm{keV} / \mathrm{dis}$ integration to $\mathrm{g}-\mathrm{rad} / \mu \mathrm{Ci}-\mathrm{h}$. The equilibrium absorbed dose, Deq, in rads equals $C_{129} \times \underset{i}{i} i$, where concentration is given in units of $\mu \mathrm{Ci}-\mathrm{h} / \mathrm{g}$. One $\mathrm{g}-\mathrm{rad} / \mu \mathrm{Ci}-\mathrm{h}=2.78 \times 10^{-3} \mathrm{H} / \mathrm{Ci}$. 
Table III-14. Fission Product Iodine from Spent LMFBR Fuel and Its Decay. (Basis: 1 metric ton of fuel. Calculated by ORIGEN Code [CLARK-1975].)

\begin{tabular}{|c|c|c|c|c|c|c|c|c|c|c|}
\hline \multirow[b]{3}{*}{ Is otope } & \multicolumn{10}{|c|}{ Time after Discharge from Reactor } \\
\hline & \multicolumn{2}{|c|}{ od } & \multicolumn{2}{|c|}{$90 \mathrm{~d}$} & \multicolumn{2}{|c|}{$150 \mathrm{~d}$} & \multicolumn{2}{|c|}{$365 d$} & \multicolumn{2}{|l|}{$10 y$} \\
\hline & ci & 8 & ci & 8 & Gi & 8 & $\mathbf{c i}$ & 8 & ci & 8 \\
\hline I-127 & 0 & 74.6 & o & 76.8 & $\mathbf{0}$ & 77.5 & o & 78.6 & $\mathbf{0}$ & 78.9 \\
\hline$I-129$ & $3.90 \times 10^{-2}$ & 239 & $3.94 \times 10^{-2}$ & 241 & $3.94 \times 10^{-2}$ & 242 & $3.94 \times 10^{-2}$ & 242 & $3.94 \times 10^{-2}$ & 242 \\
\hline$x-131$ & $1.40 \times 10^{6}$ & 11.3 & $6.16 \times 10^{2}$ & $4.97 \times 10^{-3}$ & 3.51 & $2.84 \times 10^{-5}$ & $3.15 \times 10^{-8}$ & $2.54 \times 10^{-15}$ & o & 0 \\
\hline I-132 & $1.62 \times 10^{6}$ & • & $7.40 \times 10^{-3}$ & • & $2.14 \times 10^{-8}$ & - & $2.50 \times 10^{-28}$ & - & 0 & 0 \\
\hline
\end{tabular}


Table III-15. Amounts of Iodine Isotopes Found in 1 MTHM of Different Reactor Fuels One Year After Discharge [CROFF-1980, CLARK-1975].

\begin{tabular}{|c|c|c|c|c|c|}
\hline \multirow{2}{*}{$\begin{array}{l}\text { Reactor } \\
\text { Type }\end{array}$} & \multirow{2}{*}{$\begin{array}{l}\text { Fuel } \\
\text { Burnup, } \\
\text { MWd/MT }\end{array}$} & \multirow{2}{*}{$\begin{array}{l}\text { Mass } \\
\mathrm{I}-127 \\
\mathrm{~g}\end{array}$} & \multicolumn{2}{|c|}{$I-129$} & \multirow{2}{*}{$\frac{I-129}{I \text { Tota1 }} \times 100$} \\
\hline & & & $\mathbf{g}$ & $\mathrm{Ci}$ & \\
\hline PWR & 33,000 & 55 & 179 & 0.0316 & 76.5 \\
\hline BWR & 27,500 & 45.6 & 149.7 & 0.02644 & 76.6 \\
\hline $\begin{array}{c}\text { LMFBR } \\
\text { Core }+ \text { axial } \\
\text { blanket }\end{array}$ & 64,770 & 201.8 & 510.2 & 0.09011 & 71.7 \\
\hline $\begin{array}{l}\text { LMFBR } \\
\text { Blended fuel }\end{array}$ & -- & 78.6 & 242 & 0.0399 & 75.4 \\
\hline
\end{tabular}

\section{Collection of Iodine}

Collection processes must be capable of removing several iodine species from process $s$ treams, including elemental iodine, inorganic iodine compounds, and organic iodine compounds. The latter are formed from interactions of iodine, nitric acid, solvent, and carbon contained in fuel materials [BURGER-1979A]. Methyl iodide, $\mathrm{CH}_{3} \mathrm{I}$, is the species usually mentioned in discussions of the problem, but the general term, organic iodides, is commonly employed, inplying that more than one organic species, unidentified, may be present.

According to Burger et al. [BURGER-1981A], there are three currenty favored techniques for removal of iodine from off-gas streams of fuel reprocessing plants: Mercurex, Iodox, and solid sorbents. A fourth process, caustic scrubbing, which has fallen into disfavor chiefly because of its inability to remove organic iodine compounds from the off-gas stream, is still considered by them to be a viable process. These methods are discussed in detail by several reviewers [BOND, BROWN-1980, BURGER-1979A, -1981A, HOLLADAY-1979, and MAILEN]. A description of each process based on these reviews follows.

\section{a. Mercurex}

The mercury nitrate-nitric acid scrubbing process has been demonstrated in both packed and busble-cap columns and is capable of removing both inorganic and organic iodides from LWR-LMFBR fuel reprocessing of $f-g a s e s$. Adequate residence time must be provided to decompose organic iodide species; improved organic iodides removal is associsted with higher nitric acid concentrations [BURGER-1979B]. Organic iodjdes react to form $\mathrm{HgI}_{2}$ and organic nitrates or alcohols. The overall efficiency of the process is controlled by 
the extent of bleed-cff of the accumulated $\mathrm{I}^{-}$and $\mathrm{IO}_{3}^{-}$from the recycle solution.

The chemical reactions that are operative in this

$$
6 \mathrm{I}_{2}+6 \mathrm{Hg}\left(\mathrm{NO}_{3}\right)_{2}+6 \mathrm{H}_{2} \mathrm{O} \rightleftharpoons 5 \mathrm{HgI}_{2}+\mathrm{Hg}\left(\mathrm{IO}_{3}\right)_{2}+12 \mathrm{HNO}_{3}
$$

and

$$
\mathrm{CH}_{3} \mathrm{I}+1 / 2 \mathrm{Hg}\left(\mathrm{NO}_{3}\right)_{2} \rightleftharpoons 1 / 2 \mathrm{HgI}_{2}+\mathrm{CH}_{3} \mathrm{NO}_{3}
$$

or

$$
\mathrm{CH}_{3} \mathrm{I}+1 / 2 \mathrm{Hg}\left(\mathrm{NO}_{3}\right)_{2}+\mathrm{H}_{2} \mathrm{O} \rightleftharpoons 1 / 2 \mathrm{HgI}_{2}+\mathrm{CH}_{3} \mathrm{OH}+\mathrm{HNO}_{3}
$$

The sorption of $\mathrm{NO}_{x}$ from the off-gas stream, which forms nitrous acid, inhibits formation of $\mathrm{Hg}_{(}\left(\mathrm{IO}_{3}\right)_{2}$. Because of the low solubility of mercuric iodate in nitric acid solution, this sorption is advantageous to the process.

Some work has been performed to study the conversion of the aqueous $\mathrm{HgI}_{2}$ product of the Mercurex process to $\mathrm{Ba}\left(\mathrm{IO}_{3}\right)_{2}$, a compound that is a currently acceptable chemical form for disposal in concrete [ROGERS]. This conversion also fulfills three other important requirements: (1) separating the iodine species from the scrubbing process, (2) reducing the mercury requirements of the process, and (3) eliminating the disposal of large quantities of mercury with the radioactive iodine. The conceptual plan, not yet fully developed, is (1) electrolytic [BURGER-1979B] or nitric acid [PARTRIDGE] oxidation of mercuric iodide to produce insoluble nercuric iodate, (2) contact of the mercuric iodate with sodium hydroxide to produce mercuric oxide and sodium iodate, and (3) precipitation of barium iodate from the reaction of aqueous sodium iodate with barium hydroxide. The nitric acid oxidation is effectual only at selected conditions [PARTRIDGE]. (The HgO product of the reaction of $\mathrm{Hg}\left(\mathrm{IO}_{3}\right)_{2}$ and $\mathrm{NaOH}$ would be reacted with nitric acid to produce $\mathrm{Hg}\left(\mathrm{NO}_{3}\right)_{2}$ for reuse in the scrubbing process.) These steps, which most likely would be carried out in a batch mode, are slow, and the separation of the solid products would be difficult. Another disadvantage of this process is that aromatics in the feed gas greatly diminish the iodine DF [HOLIADAY-1979]. An alternative, in development at the Mol, Belgium plant, is electrolytic reduction to metallic mercury and precipitation of CuI, requiring a reductant for the $I_{2}$ that is formed [BURGER-1982B].

Advantages for this process are that $\mathrm{I}_{2}$ and $\mathrm{CH}_{3} \mathrm{I}$ can be removed simultaneously with appreciable DF's, and this removal is relatively unaffected by the presence of water vapor or trace amounts of dodecane or octane. Also, the presence of $\mathrm{NO}_{\mathrm{X}}$ in the off-gas stream actually benefits the process by preventing the formation of the insoluble $\mathrm{Hg}\left(\mathrm{IO}_{3}\right)_{2}$. Because the concentration of nitric acid is subazeotropic $(2-14 \mathrm{M})$, the scrubber equipment can be constructed of stainless steel, and no special in-plant equipment to produce hyperazeotropic $\mathrm{HNO}_{3}$ is necessary. (Both of these points are advantages over the Iodox process, discussed next.) Retention factors of $>10^{3}$ have been 
obtained in laboratory tests of the Mercurex process, but the full-scale process designed for the Allied-General Nuclear Services reprocessing plant claims retention factors of on $1 y$ 10-75; this process alone is therefore probably not adequate for process application, but may be sufficient if backed up by solid sorbents [BURGER-1979A].

\section{b. Iodox}

The Iodox process is a wet scrubbing system in which the offgas stream of a fuel reprocessing plant is contacted by 20-22 $\mathrm{M} \mathrm{HNO}_{3}$ (hyperazeotropic nitric acid) in a bubble-cap scrubber. The reaction scheme for iodine removal is the sequence:

$$
\begin{gathered}
\mathrm{I}_{2}+4 \mathrm{HNO}_{3} \rightleftharpoons 2 \mathrm{I}^{+}+2 \mathrm{NO}_{3}^{-}+\mathrm{N}_{2} \mathrm{O}_{4}+2 \mathrm{H}_{2} \mathrm{O} \\
\mathrm{I}^{+}+3 \mathrm{HNO}_{3}+\mathrm{NO}_{3}^{-} \rightleftharpoons \mathrm{IO}_{3}^{-}+\mathrm{H}^{+}+2 \mathrm{~N}_{2} \mathrm{O}_{4}+\mathrm{H}_{2} \mathrm{O}
\end{gathered}
$$

Reaction ILI-12 is fast and reaction III-13 is rate-determining. For aliphatic iodide compounds, there is an initial fast nitration reaction:

$$
\mathrm{CH}_{3} \mathrm{I}+2 \mathrm{HNO}_{3} \rightleftharpoons \mathrm{CH}_{3} \mathrm{NO}_{3}+1 / 2 \mathrm{I}_{2}+1 / 2 \mathrm{~N}_{2} \mathrm{O}_{4}+\mathrm{H}_{2} \mathrm{O}
$$

The oxidation of $\mathrm{I}_{2}$ then follows reactions $I I I-12$ and -13 . The acidic iodate can be concentrated to form $\mathrm{HI}_{3} \mathrm{O}_{8}$ or precipitated as the slightly soluble $\mathrm{Ba}\left(\mathrm{IO}_{3}\right)_{2}$, although this step is untested.

Iodox is capable of retention factors of $>10^{4}$ and is probably adequate to meet the requirements of 40 CFR $190^{*}$ [BURGER-1979A]. The major disadvantage to the Iodox process is the high capital cost associated with building its equipment from acid-resistant materials such as zirconium or titanium; the hyperazeotropic nitric acid would also need to be produced inplant. If fluorides are introduced in the reprocessing flowsheet (e.g., in processing denatured thorium-uranium fuel in the Zirflex process), corrosion problems would be more severe. Another disadvantage is the potential for accumulating explosive organic nitrates in the Iodox scrubber.

There are two major advantages to the Iodox process: (1) no new chemicals are added to the reprocessing plant operation, and (2) the product of the process, $\mathrm{HI}_{3} \mathrm{O}_{8}$, is easily converted to $\mathrm{Ba}\left(\mathrm{IO}_{3}\right)_{2}$, a preferred disposal form.

\section{c. Solid Sorbents}

Silver-coated alumina and alumina-silica combinations yield iodine-retention factors of $>10^{3}$, but there are occasional, unexplained reductions in iodine-retention factors in process conditions [BURGER-1979A].

\footnotetext{
Fertinent sections of the Code of Federal Regulations are referenced at end of this report.
} 
Silver-exchanged zeolites and Bilver-nitrate-impregnated amorphous materials, on the other hand, are becoming wore highly regarded as means for collecting radioactive iodine from a fuel reprocessing plant's dissolver off-gas. Com mercially available mater faujasite (AgX), silver-exchanged mordenite (AgZ), and silver-nitrateimpregnated amorphous silicic acid (AC-6120). Silver-exchanged zeolites appear to trap iodine by at least two mechanisms: physical sorption and chemical reaction to form silver iodide. A simplified chemical equation for the reaction would be:

$$
\mathrm{Ag}_{2} \mathrm{O}_{(\mathrm{s})}+\mathrm{I}_{2(\mathrm{~g})} \gtrless 2 \mathrm{AgI}(\mathrm{s})+1 / 2 \mathrm{O}_{2(\mathrm{~g})}
$$

It is speculated that the reaction of aliphatic iodides is:

$$
\mathrm{Ag}_{2} \mathrm{O}(\mathrm{g})+\mathrm{H}_{2} \mathrm{O}+2 \mathrm{CH}_{3} \mathrm{I}_{(\mathrm{g})} \rightleftharpoons 2 \mathrm{AgI}_{(\mathrm{g})}+2 \mathrm{CH}_{3} \mathrm{OH}_{(\mathrm{g})}
$$

The reason for suspecting at least two mechanisms for the retention of iodine is that there appear to be two types of iodine species-one tightly bound and therefore difficult to remove, the other easily displaced. Accozding to [JUBIN], a typical loading for $\mathrm{AgX}$ at $150^{\circ} \mathrm{C}$ would be $349 \mathrm{mg} \mathrm{I} / \mathrm{g} \mathrm{AgX;} 214 \mathrm{mg} / \mathrm{g}$ AgX is chemisorbed and $135 \mathrm{mg} / \mathrm{g} \mathrm{AgX}$ is physisorbed. The large chemisorption of AgX compared to other metal zeolites is explained by the casacity of $\mathrm{Ag}^{+}$ to bond by the following mechanism:

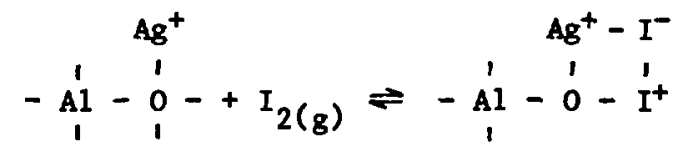

Studies have shown that silver sorbents can be regenerated with hydrogen $8 a 8$ at $400-500^{\circ} \mathrm{C}$ with the liberation of hydrogen iodide gas:

$$
2 \mathrm{AgI}_{(\mathrm{s})}+\mathrm{H}_{2(\mathrm{~g})} \rightleftharpoons 2 \mathrm{Ag}(\mathrm{g})+2 \mathrm{HI}(\mathrm{g})
$$

Lead-exchanged zeolites ( $\mathrm{PbX}$ ) $\mathrm{c}$ an be used to chenisorb the HI produced by this reaction. Because of the substantially lower cost of lead than $s$ ilver, $\mathrm{PbX}$ is a potentially more favorable waste form. Early indications, however, are that PbXI is noc a stable material and may rot be a satisfactory disposal form imbedaed in concrete.

When silver-nitrate-impregnated amorphous silica is the sorbent, the reaction sequence has been shown to be:

$$
\begin{gathered}
\mathrm{AgNO}_{3(\mathrm{~s})}+\mathrm{I}_{2(\mathrm{~g})} \rightleftharpoons \mathrm{AgI}(\mathrm{s})+\mathrm{INO}_{3} \\
2 \mathrm{INO}_{3}+\mathrm{AgNO}_{3} \Rightarrow \mathrm{AgIO}_{3}+3 \mathrm{NO}_{2}+1 / 2 \mathrm{~L}_{2} \\
\mathrm{INO}_{3} \rightleftharpoons \mathrm{NO}_{2}+1 / 2 \mathrm{O}_{2}+1 / 2 \mathrm{I}_{2}
\end{gathered}
$$

By analogy, the speculated mechaniam for the reaction of methyl iodide would be: 


$$
\mathrm{AgNO}_{3(8)}+\mathrm{CH}_{3} \mathrm{I} \rightleftharpoons \mathrm{ABI}(\mathrm{s})+\mathrm{CH}_{3} \mathrm{NO}_{3(8)}
$$

Regeneration of the silver-nitrate-1upregnated slliclc actd, although untested, should also be possible.

The jor disadvantage of silver sorbents is their high cost, which 18 very inportant if they are considered as a terainal waste form. It $1 s$, however, possible to convert the lodine to $\mathrm{PbXI}$ or even to $\mathrm{Ba}\left(\mathrm{IO}_{3}\right)_{2}$ in subsequent chentcal steps. Silver sorbent collection has major advantages of being inherently less complicated than wet scrubbing methods and less expensive to operate.

\section{d. Caustic Scrubbing}

In theory, caugtic scrubbers should be able to remove elemental $I_{2}$ from the off-gas atream by the well-known disproportionation reaction:

$$
3 \mathrm{I}_{2}+6 \mathrm{OH}^{-} \rightleftharpoons 5 \mathrm{I}^{-}+\mathrm{IO}_{3}^{-}+3 \mathrm{H}_{2} \mathrm{O}
$$

In practice, they have never been more than $90 \%$ efficlent, partially because of their inability to remove orgenic lodides from the off-gas stream. They also trap $\mathrm{CO}_{2}$ and $\mathrm{NO}_{\mathrm{x}}$; the radioactive lodine and carbon could be separated fron these mixtures as precipitated barium compounds, $\mathrm{Ba}\left(\mathrm{CO}_{3}\right)_{2}$ and $\mathrm{Ba}\left(\mathrm{IC}_{3}\right)_{2}$.

\section{e. Conclusion}

All four processes are capable of producing $\mathrm{Ba}\left(\mathrm{IO}_{3}\right)_{2}$ that can be incorporated in concrete for terminal disposal; the Iodox process does this most effectively. If sorption by silver sorbents is the preferred collection method, an alternative to disposal of lodine as $\mathrm{Ba}\left(\mathrm{IO}_{3}\right)_{2}$ in concrete would be disposal of AgZI, ABXI, and PBXI either as-received or encapsulated in concrete.

\section{Imobilization of Iodine}

Given below are the results of our investigation of the chemical and physical paraneters important to methods for immobilizing lodine. The two primary methods are (1) incorporating $\mathrm{Ba}\left(\mathrm{IO}_{3}\right)_{2}$ into concrete and (2) collecti:18 I-129 with silver sorbents and then disposing of them. Other lodine inmobilization methods are also discussed.

$$
\text { a. } \mathrm{Ba}\left(\mathrm{IO}_{3}\right)_{2} \text { in Concrete }
$$

\section{(1) Solubility Data}

Although barfum lodate is spoken of as an insoluble compound, it does have a measurable solubility in water. The solubility daca presented In F1g. III-7 are complled from several souxces and were measured with an Ionic trength of $O$ (no other anions or cations present). These 


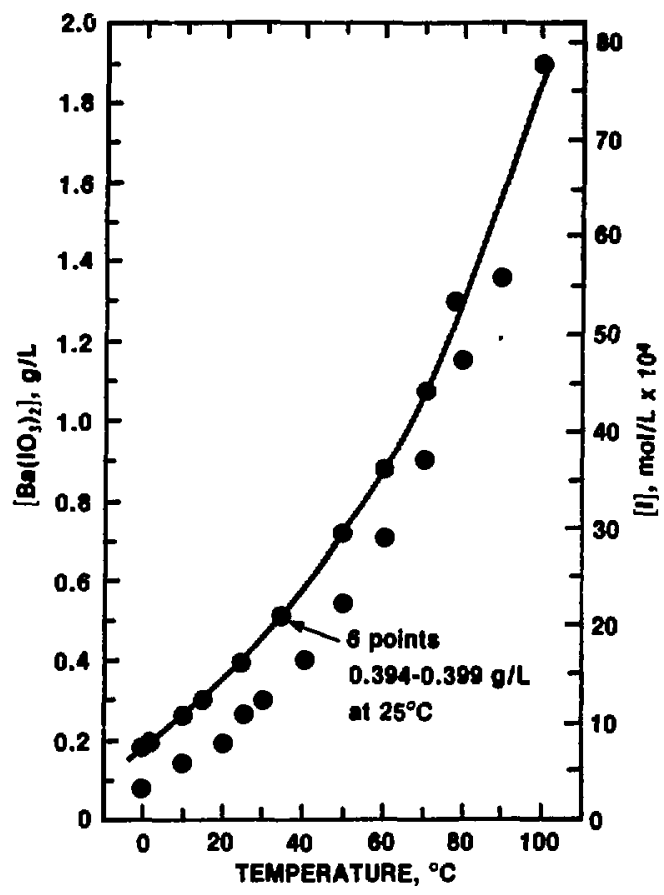

Fig. III-7. Solubility of $\mathrm{Ba}\left(\mathrm{IO}_{3}\right)_{2}$ vs.

Temperature [BOUSQUET-1 $\overline{969} \mathrm{~A}$, GMELIN-1960 LINKE, FEPOROV, JONES-1973B, and STEPHEN] . (The data points below the line were ignored. They all cane from the same experimenters, whose measurement at $25^{\circ} \mathrm{C}$ did not agree with the consensus of six independent measurements.)

data show a significant temperature dependence for the solubility of $\mathrm{Ba}\left(\mathrm{IO}_{3}\right)_{2}$ in water; there is a tenfold increase in the solubility over the temperature range $0-100^{\circ} \mathrm{C}$.

Data on the solubility of barium iodate in pure water is not enough to degcribe the behavior of $\mathrm{Ba}\left(\mathrm{IO}_{3}\right)_{2}$ under practical conditions. Conplexing of $\mathrm{Ba}^{2+}$ by other, anions can increase the solubility of $\mathrm{Ba}\left(\mathrm{IO}_{3}\right)_{2}$ ubstantially, as can changes in the ionic strength of the aqueous environment. Fedorov et al. have shown this effect by varying the ionic strength with mixt ures of $\mathrm{LiClO}_{4} / \mathrm{LiNO}_{3}$ between 0.5 and $4.0 \mathrm{M}$ [FEDOROV]. The solubility of $\mathrm{Ba}\left(\mathrm{IO}_{3}\right)_{2}$ was increased by both increases in the ionic atrength and the nitrate concentration. Formation constants for $\mathrm{Ba}\left(\mathrm{NO}_{3}\right)^{+}$and $\mathrm{Ba}\left(\mathrm{NO}_{3}\right)_{2}$ were both mesurable. Figure III-8 shows the effect of nitrate concentration on the solubility of $\mathrm{Ba}\left(\mathrm{IO}_{3}\right)_{2} ; \mathrm{ClO}_{4}^{-}$was used to maintain constant ionic strength and was assumed not to complex $\mathrm{Ba}^{2+}$. 


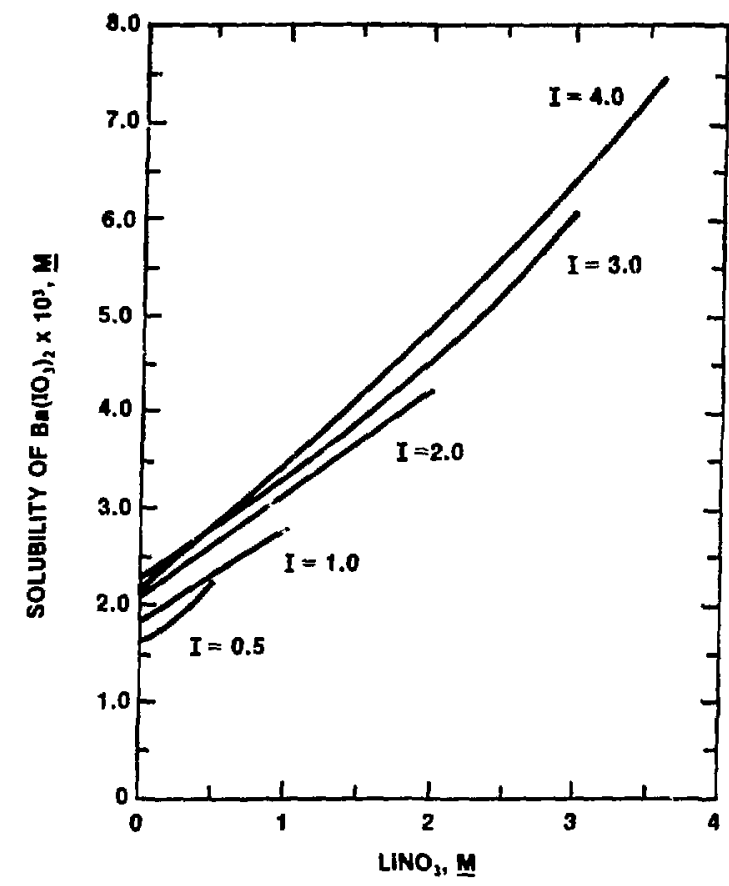

Fig. III-8. The Effect of $\mathrm{NO}_{3}^{-}$and ionic Strength $(I)$ on the Solubility of $\mathrm{Ba}\left(\mathrm{IO}_{3}\right)_{2}$ at $25^{\circ} \mathrm{C}$ [FEDOROV].

The rate of dissolution of $\mathrm{Ba}\left(\mathrm{IO}_{3}\right)_{2} \cdot \mathrm{H}_{2} \mathrm{O}$ was measured by Jones et a1. [JONES-1973A]. In relating their data by a model that considered both slow chemical processes at the surface of the crystal and diffusion through the water layer near the surface, Jones et al. determined that the dissolution rate was basically controlled by diffusion; there was no great chemical resistance to dissolution.

\section{(2) Thermal Stability}

It is known that $\mathrm{Ba}\left(\mathrm{IO}_{3}\right)_{2} \cdot \mathrm{H}_{2} \mathrm{O}$ is the stable form at ambient temperatures and humidities. According to [DUVAL], as $\mathrm{Ba}\left(\mathrm{IO}_{3}\right)_{2} \cdot \mathrm{H}_{2} \mathrm{O}$ is heated, dehydration begins at $43^{\circ} \mathrm{C}$, is barely discernible at $60^{\circ} \mathrm{C}$, and accelerates near $79^{\circ} \mathrm{C}$. A decrease in the rate of water weight loss with increasing tenperature is observed when $75 \%$ of the water of hydration is removed and the 1083 of the last $25 \%$ proceeds more and more slowly. Complete 10ss is not obtained until $320^{\circ} \mathrm{c}$. (On the other hand, [BISWAS] reports water $10 s 8$ of $\mathrm{Ba}\left(\mathrm{IO}_{3}\right)_{2} \cdot \mathrm{H}_{2} \mathrm{O}$ is messurable in the range of 80 to $180^{\circ} \mathrm{C}$. The watez of hydration returns spontaneously as the $\mathrm{Ba}\left(\mathrm{IO}_{3}\right)_{2}$ is left to stand in the atmosphere.) There is no change in weight; $108 s$ or in the differential thermal 
analygis curve of pure $\mathrm{Ba}\left(\mathrm{IO}_{3}\right)_{2}$ between $320^{\circ}$ and $476^{\circ} \mathrm{C}$, until the Rammelsberg reaction begins:

$$
5 \mathrm{Ba}\left(\mathrm{IO}_{3}\right)_{2} \rightleftharpoons \mathrm{Ba}_{5}\left(\mathrm{IO}_{6}\right)_{2}+9 \mathrm{O}_{2}+4 \mathrm{I}_{2}
$$

Reaction III-24 becomes violent when the temperature $610^{\circ} \mathrm{C}$ is reached. This reaction was complete by $666^{\circ} \mathrm{C}$, and no further reaction was seen before Duval et al. stopped their scan at $950^{\circ} \mathrm{C}$.

The presence of a purely acidic substance, $\mathrm{CO}_{2}$, does not greatly change the decomposition temperature for $\mathrm{Ba}\left(\mathrm{IO}_{3}\right)_{2}$, but does change the decomposition product yields [GONTARZ-1974, -1980]. $\mathrm{As} \mathrm{Ba}\left(\mathrm{IO}_{3}\right)_{2}$ decomposes in the presence of $\mathrm{CO}_{2}$, the reaction becomes:

$$
\mathrm{Ba}\left(\mathrm{IO}_{3}\right)_{2}+\mathrm{CO}_{2} \Rightarrow \mathrm{I}_{2}+\mathrm{BaCO}_{3}+2.5 \mathrm{O}_{2}
$$

These same authors studied the effect of $\mathrm{BaO}$ and $\mathrm{I}^{-}$on the thermal decomposi$t$ ion of iodate. When the ratio of $\mathrm{Ba}\left(\mathrm{IO}_{3}\right)_{2} / \mathrm{BaO}$ was $1 / 4$, the onset of decomposition was measured at $330^{\circ} \mathrm{C}$ by differential thermal analysis; there was no weight loss during decomposition. The decomposition was determined to be one of disproportionation of iodate:

$$
4 \mathrm{IO}_{3}^{-}+6 \mathrm{O}^{2-} \Rightarrow 3 \mathrm{IO}_{6}^{5-}+\mathrm{I}^{-}
$$

They also found that the addition of iodide to iodate salts substantially reduced the decomposition temperature. For example, a mixture of $\mathrm{Ca}\left(\mathrm{IO}_{3}\right)_{2}$ and $5 \mathrm{CaI}_{2}$ began to decompose at $330^{\circ} \mathrm{C} ; \mathrm{Ca}\left(\mathrm{IO}_{3}\right)_{2}$ alone showed no signs of decomposition until $480^{\circ} \mathrm{C}$. The decomposition reaction is believed to be:

$$
2 \mathrm{IO}_{3}^{-}+3 \mathrm{I}^{-} \rightleftharpoons \mathrm{IO}_{6}^{5-}+2 \mathrm{I}_{2}
$$

In conclusion, the thermal decomposition of $\mathrm{Ba}\left(\mathrm{IO}_{3}\right)_{2}$ does not appear to be of great concern. The low amounts of heat generated by the radioactive decay of I-129 is not enough to significantly raise the waste form above its ambient temperature. It has been shown that the chemical environment affects both the minimum temperature of decomposition and the decomposition product. Unless there are extraordinary curing procedures for the concrete before storage, the stability of $\mathrm{Ba}\left(\mathrm{IO}_{3}\right)_{2}$ under thermal conditions likely to be encountered in a disposal site is assured. In a basic environment like concrete, reaction III-26 would likely occur on heating the waste form above $330^{\circ} \mathrm{C}$. Since the iodine species produced in reaction III-26 are not volatile as $\mathrm{Ba}^{2+}$ or $\mathrm{Ca}^{2+}$ alts, there would be no immediate iodine release in a heat-producing transportation accident. The fraction of $\mathrm{I}^{-}$, however, would decrease the leach resistance of the waste form because of the much greater water olubility of $\mathrm{BaI}_{2}$ vs. that of $\mathrm{Ba}\left(\mathrm{IO}_{3}\right)_{2}$. 


\section{(3) Heat Capecity}

The molar heat capacity of $\mathrm{Ba}\left(\mathrm{IO}_{3}\right)_{2}$ was measured by Bousquet et al. [BOUSQUET-1969B] between 10 and $650 \mathrm{~K}$. In the range 300-650 $\mathrm{K}$ the molar heat capacity, $c_{p}$, in units of cal degree mol $^{-1}$ can be calculated by the relationship

$$
C_{p}=59.64-1.48 \times 10^{6} \mathrm{~T}^{-2}
$$

\section{(4) Point of Zero Charge}

The point of zero charge (PZC) is the concentration of the cation $\mathrm{M}^{\mathbf{2}}$ or anion $A^{\mathrm{X}-}$ at which point the net charge of the precipitate, $M_{x} A_{z}$, is neither positive nor negative. As pointed out by [HONIG], for $\mathrm{Ba}\left(\mathrm{IO}_{3}\right)_{2}$, if there are equal equivalents of $\mathrm{Ba}^{2+}$ and $\mathrm{IO}_{3}^{-}$in solution ( $\left[\mathrm{IO}_{3}^{-}\right]=2\left[\mathrm{Ba}^{2+}\right]$ ), the precipitate has a positive charge. The surface charge of precipitated barium iodate does not become neutral until the concentration of iodate in the aqueous phase is equal to or larger than $0.11 \mathrm{M}$. (The concentration of $\mathrm{Ba}^{2+}$ is set by the solubility product.) other anions in solution would of course also, to some extent, modify the positive charge of the precipitate.

The charge of a precipitate is very much a function of the cations and anions in the salt. Silver iodide, for example, has a negative charge at its equivalence point. A high surface charge of a precipitate is the major contribution to (1) the formation of the colloidal precipitate and (2) the stability of the colloidal suspension. The sorption of ions on a solid or one solid on another is a function of a materials surface charge.

\section{(5) Redox Behavior of Iodine Species}

Table III-16 is a compilation of relevant oxidationreduction couples in acid solution. In a basic environment like portland cement, $\mathrm{IO}_{3}{ }^{-}$would appear to be stable to reduction to iodide by water or hydroxide. Once it is leached out of the concrete into an anoxic groundwater at $\mathrm{pH} 7-9$, it would be reduced by $\mathrm{Fe}$ (II) to iodide [ALLARD-1980]. Allard et al. give the redox potential of deep anoxic groundwaters to be less than $\overline{0.12 \mathrm{~V}}$ at $\mathrm{pH}=8$. The redox potentials for iodine species are also given by the following relationships:

$$
\begin{aligned}
& \mathrm{I}^{-} / \mathrm{IO}_{3}{ }^{-} \quad \mathrm{E}=1.09-0.0592 \mathrm{pH} \\
& \mathrm{I}^{-} / \mathrm{IO}^{-} \quad \mathrm{E}=1.32-0.0592 \mathrm{pH} \\
& \mathrm{I}^{-} / \mathrm{I}_{2(\mathrm{~s})} \mathrm{E}=0.536+0.0592 \mathrm{pI}^{-}
\end{aligned}
$$

Accoraing to Clark and Howerton [CLARK-1980], the presence of sulfite in portland cement reduces some of the $\mathrm{Ba}\left(\mathrm{IO}_{3}\right)_{2}$ encapsulated in the concrete to $\mathrm{BaI}_{2}$. 
Table III-16. Redox Potentials Pertinent to $\mathrm{Ba}\left(\mathrm{IO}_{3}\right)_{2}$ in Concrete [DEAN, MCMANUS, PLATT-1978]

\begin{tabular}{|c|c|c|}
\hline \multicolumn{2}{|c|}{ Half Reaction } & \multirow{2}{*}{$\begin{array}{l}\begin{array}{l}\text { Standard Potential } \\
\text { at } 25^{\circ} \mathrm{C} \text { in Volts }\end{array} \\
-2.91\end{array}$} \\
\hline $\mathrm{Ba}^{2+}+2 \mathrm{e}^{-}$ & $\Rightarrow \mathrm{Ba}$ & \\
\hline $\mathrm{H}_{5} \mathrm{IO}_{6}+\mathrm{H}^{+}+2 \mathrm{e}^{-}$ & $\Rightarrow \mathrm{IO}_{3}-+3 \mathrm{H}_{2} \mathrm{O}$ & +1.6 \\
\hline $\mathrm{IO}_{3}^{-}+5 \mathrm{H}^{+}+4 \mathrm{e}^{-}$ & $\Rightarrow \mathrm{HIO}+2 \mathrm{H}_{2} \mathrm{O}$ & +1.14 \\
\hline $\mathrm{IO}_{3}^{-}+6 \mathrm{H}^{+}+5 \mathrm{e}^{-}$ & $\rightleftharpoons 1 / 2 \mathrm{I}_{2}+3 \mathrm{H}_{2} \mathrm{O}$ & +1.19 \\
\hline$I_{2(a q)}+2 e^{-}$ & $\rightleftharpoons 2 \mathrm{I}^{-}$ & +0.621 \\
\hline $\mathrm{IO}_{3}^{-}+3 \mathrm{H}_{2} \mathrm{O}+6 \mathrm{e}^{-}$ & $\neq I^{-}+60 \mathrm{H}^{-}$ & +0.26 \\
\hline $\mathrm{SO}_{4}^{2-}+\mathrm{H}_{2} \mathrm{O}+2 \mathrm{e}^{-}$ & $\Rightarrow \mathrm{SO}_{3}{ }^{2-}+2 \mathrm{OH}^{-}$ & -0.93 \\
\hline $\mathrm{O}_{2}+2 \mathrm{H}_{2} \mathrm{O}+4 \mathrm{e}^{-}$ & $\Rightarrow 40 \mathrm{H}^{-}$ & +0.41 ( $1 \underline{M} \mathrm{NaOH})$ \\
\hline $\mathrm{O}_{2}+4 \mathrm{H}^{+}+4 \mathrm{e}^{-}$ & $\Rightarrow 2 \mathrm{H}_{2} \mathrm{O}$ & +1.229 \\
\hline $\operatorname{Fe}(I I I)+e^{-}$ & $\neq \operatorname{Fe}(I I)$ & +0.771 \\
\hline $\mathrm{Fe}(\mathrm{OH})_{3}+3 \mathrm{H}^{+}+\mathrm{e}^{-}$ & $\Rightarrow \mathrm{Fe}^{2+}+3 \mathrm{H}_{2} \mathrm{O}$ & +0.93 \\
\hline
\end{tabular}

(6) Density of $\mathrm{Ba}\left(\mathrm{IO}_{3}\right)$ and $\mathrm{Ba}\left(\mathrm{IO}_{3}\right)_{2} \cdot \mathrm{H}_{2} \mathrm{O}$

According to [DEAN], the density of $\mathrm{Ba}\left(\mathrm{IO}_{3}\right)_{2}$ (molecular welght $=487.15 \mathrm{~g} / \mathrm{mol}$ ) $1 \mathrm{~s} 5.23 \mathrm{~g} / \mathrm{cm}^{3}$ at $20^{\circ} \mathrm{C}$. The density of 1 ts monohydrate, $\mathrm{Ba}\left(\mathrm{IO}_{3}\right)_{2} \cdot \mathrm{H}_{2} \mathrm{O}$ (molecular weight $=505.16 \mathrm{~g} / \mathrm{mol}$ ), is $4.657 \mathrm{~g} / \mathrm{cm}^{3}$ at $18^{\circ} \mathrm{C}$.

(7) Leaching Behavior of $\mathrm{Ba}\left(\mathrm{IO}_{3}\right)_{2}$ in Concrete

According to [ALTOMARE], the Incorporation of $\mathrm{Ba}\left(\mathrm{IO}_{3}\right)_{2}$ in concrete $1 \mathrm{~s}$ a prime candidate for disposal of 129 I because:

- The encapsulation 18 a low temperature process. Iodine compounds are not stable at the high temperatures of glass formation; encapsulation of 129 I in borosilfcate glass 18 therefore not practical.

- Barlum lodate has low aqueous solubtlity.

- Barlun lodate can be prepared directly from partially soluble barfum hydroxide and the product of the Iodox process without the addition of superfluous lonic species. All the resulting slurry of $\mathrm{Ba}\left(\mathrm{IO}_{3}\right)_{2}$ can be Incorporated in the concrete to there is no secondary liquid waste. 
The incorporation of $\mathrm{Ba}\left(\mathrm{IO}_{3}\right)_{2}$ in concrete has been tested with a very strong emphasis on leaching characteristics by researchers at ORNL [CLARK-1976, -1977A, -1977B, -1978, -1980; MOORE; MORGAN-1979] and at PNL [BURGER-1981A, -1981B; CHIKALLA-1981A, -1981B, -1981C].

Researchers at ORNL have reported that concrete can be prepared in the laboratory, incorporating as much as 21 wt $\%$ iodine in the form of $\mathrm{Ba}\left(\mathrm{IO}_{3}\right)_{2}$. Because of mixing difficulties with high $\mathrm{Ba}\left(\mathrm{IO}_{3}\right)_{2}$ compositions, however, they recommend a practical maximum of 15 wt $z$. The standard technique for preparation of leach samples was to mix $\mathrm{HIO}_{3}$ with a slight excess of barium hydroxide, with enough water in the resulting barium iodate slurry to make up the concrete aggregate. The type I portland cement and the $\mathrm{Ba}\left(\mathrm{IO}_{3}\right)_{2}$ slurry were mixed in a Waring-type blender, and the concrete mix poured into ( $5-\mathrm{cm}$ diameter by $5-\mathrm{cm}$ high) cylindrical polyethylene containers. After casting, the samples were allowed to 8 tand for $28 \mathrm{~d}$ or longer in a watersaturated atmosphere at room tempezature. Typical conditions were 5 wt $\%$ excess barium hydroxide and a 0.72 weight ratio of water/cement.

The leach teats at ORNL were done atatically, but the leach solution was changed to sample periodically (once a day, once a week, or, sometimes, once a month). The data collected from these tests tended to fit the pattern of a conventional leach experiment whose mechanism was controlled by diffusion. The theoretical equation for diffusion-controlled leaching is:

$$
\left(\frac{\Sigma a_{n}}{A_{0}}\right)\left(\frac{v}{s}\right)=2\left(\frac{D_{e}}{\pi}\right)^{1 / 2}(t)^{1 / 2}
$$

where $a_{n}$ is the weight of iodine per leaching period;

$A_{0}$ is the initial iodine content of the specimen in the same units as $a_{n}$;

$V$ is the leachate volume in $\mathrm{cm}^{3}$;

3 is the apparent specimen surface area in $\mathrm{cm}^{2}$;

$D_{e}$ is the modified effective diffusivity in $\mathrm{cm}^{2} / \mathrm{s}$; and

$t$ is the leaching time in 8 .

Figure III-9 shows some of the leaching data, plotted as the normalized fractional loss $\left(\Sigma a_{n} / A_{0}\right)(V / s)$ vs. the square root of $t$ ime. There appears to be a slowdown of leaching at long leach times; this slowdown, the experimenters feel, is a consequence of their changing the sampling period from daily, to weekly, and to monthly as the experiments progressed. The inflection points seen on the curves correspond to these changes in sampling procedure. The data suggest that, at least between 5 and 12 wt $z$ iodine, there is little deterioration of concrete' ability to resist leaching by the addition of $\mathrm{Ba}\left(\mathrm{IO}_{3}\right)_{2}$. As shown in $\mathrm{Fig}$. III-9, the leach resistance of concrete containing 2.9 wt $\%$ iodine is slightly higher than the other concretes. 


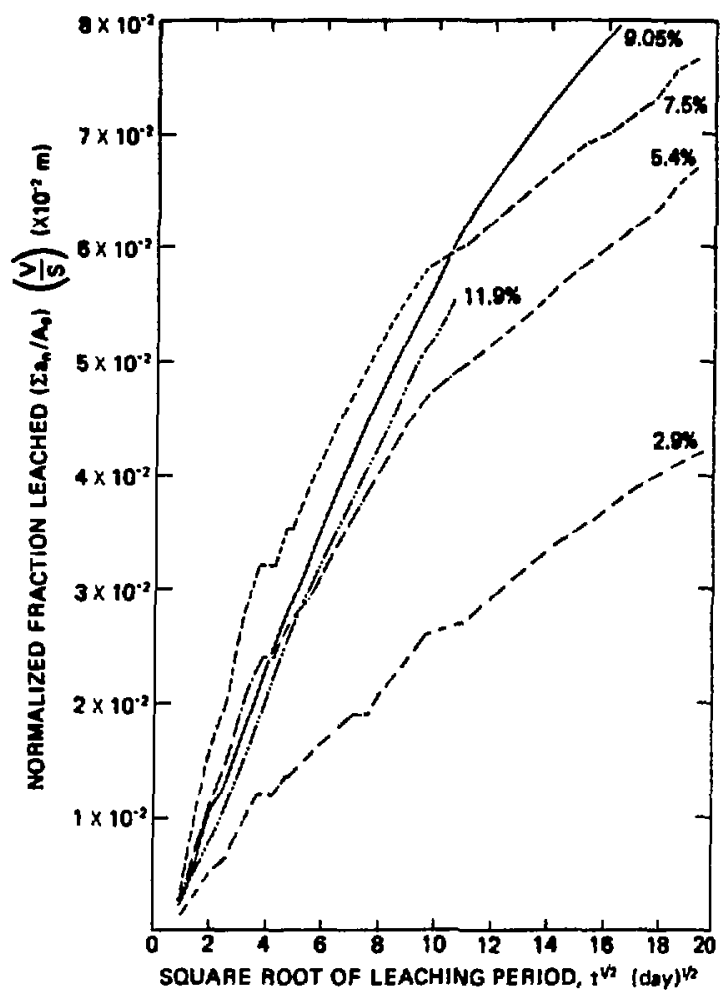

Fig. III-9. The Effect of Iodine Content on the Leach Rate of Barium Iodate Concrete, No Additives [CLARR-1977B].

Table III-17 is a summary of the results of these studies in distilled water. The influence of iodine concentration in the concrete, curing time of the concrete, excess barium hydroxide, and radiation was nil to sl ight. The maximum radiation dose produced from a Co-60 source, $2 \times 10^{7}$ rad, was equivalent to 660 y of self-irradiation but at a rate one million tines higher. The water/cement ratio and cement type had a slight effect on the leach rate. leach rates determined for iodine in type I cement concrete, used for the majority of these leach tests, were qualitatively determined to be as low or lower than those measured for iodine in the type II, III, IP, IS, and high-alumina cement concretes. The addition of fly ash to the concrete and use of low temperatures were two effective means of lowering the leach rate.

The parmeter that was determined to be the most important to the leach rate of iodine from barium iodate incorporated in concrete was the composition of the leachant. The diffusivity of iodine into various leachants is shown in Table III-18. The explanation for the much lower leach rates than in distilled water for the water that contains salts is the formation of an insoluble barrier on the face of the concrete. Scanning electron 
Table III-17. Summary of Iodine Leach Study Results from $\mathrm{Ba}\left(\mathrm{IO}_{3}\right)$ in Concrete [MOORE]

\begin{tabular}{|c|c|c|c|}
\hline Parameter & Range & $\begin{array}{l}\text { Effect on } \\
\text { Leachability }\end{array}$ & $\begin{array}{c}\text { Minimum } \\
\text { Order of } \\
\text { Magnitude of } \\
\text { Diffusivity, } \\
\mathrm{cm}^{2} / \mathrm{s}\end{array}$ \\
\hline $\begin{array}{l}\text { Iodine Concen- } \\
\text { tration }\end{array}$ & $9-21$ wt $x$ & none & $10^{-10}$ \\
\hline Curing time & $7-112 d$ & none & $10^{-10}$ \\
\hline Excess $\mathrm{Ba}(\mathrm{OH})_{2}$ & $5-25$ wt $x$ & none & $10^{-10}$ \\
\hline Radiation & $0-2 \times 10^{7}$ rads & none & $10^{-10}$ \\
\hline Fly Ash & $0-12 \%$ & inverse & $10^{-11}$ \\
\hline $\begin{array}{l}\text { Water/Cement } \\
\text { Weight Ratio }\end{array}$ & $0.5-0.9$ & slight direct & $10^{-10}$ \\
\hline Cement Type & $\begin{array}{l}\text { type I, II, } \\
\text { III, IS, IP, } \\
\text { high-alumina }\end{array}$ & slight & $10^{-10}$ \\
\hline Temperature & $3-50^{\circ} \mathrm{C}$ & slight direct & $10^{-11}$ \\
\hline
\end{tabular}

microscopy on a concrete sample leached in simulated sea water revealed a 0.5-1.0 mm surface film composed primarily of magnesium hydroxide. The surface of concretes leached by tap and groundwaters showed high concentrations of calcium and zinc, with low concentrations of strontium, iron, and titanium. (Only $\mathrm{CaCO}_{3}$ was formed on the surface of concrete leached by distilled water.)

Although it seems clear that these films are responsible for retarding the leaching of iodine from concrete, the mechanism of retardation is not at all clear. Morgan et al. 1 isted three possibilities [MORGAN]; the films

(1) act to stop erosion of the concrete,

(2) form an adsorption layer for the iodine, and

(3) form a layer of very low diffusivity between the concrete and the leachant.

They then discussed reasons why none of these mechanisms was possible. They felt that mechaniam (1) could not be important because the accumulated release of iodine was measured to be clearly proportional to the square root of time 
Table III-18. Effect of Different Leachants on the Iodine Diffusivity $\left(\mathrm{De}_{\mathrm{e}}\right)$ from $\mathrm{Ba}\left(\mathrm{IO}_{3}\right)_{2}$ in Concrete [MOORE].

\begin{tabular}{ll}
\hline \multicolumn{1}{c}{ Leachant } & $\mathrm{D}_{e}, \mathrm{~cm}^{2} / \mathrm{s}$ \\
\hline Distilled $\mathrm{H}_{2} \mathrm{O}$ & $1.3 \times 10^{-10}$ \\
Simulated Sandia Brine & $2.4 \times 10^{-11}$ \\
Simulated Sea Water & $1.5 \times 10^{-14}$ \\
0.03 M MgCl 2 & $1.7 \times 10^{-14}$ \\
ORNL Tap Water & $5.9 \times 10^{-14}$ \\
Oak Ridge Groundwater & $7.9 \times 10^{-15}$ \\
0.01 M $\mathrm{ZnCl}_{2}$ & $5.7 \times 10^{-14}$ \\
\hline
\end{tabular}

for all the leachants studied. If destruction of the concrete were the mechanism of iodine release, the accumulated loss would be linearly proportional to time. Mechanisms (2) and (3) were negated by $x$-ray fluorescence analysis data. While iodine was clearly visible in the concrete matrix, none was visible in the films; if the films were acting as either an adsorption or diffusion barrier, iodine would have been found in higher concentrations than in the concrete.

Morgan et al. conclude that their measured iodine leach rates should be considered to be an upper limit to what could be expected for the release of radioiodine from barium iodate incorporated in concrete. Leaching experiments in which the leachant is changed daily, with a zero concentration of iodine at the surface of the specimen, is not a likely condition for waste buried in a deep geologic formation or beneath the ocean floor, where flow rates are measured in the order of meters per year. Diffusion and dissolution should be greatly at tenuated under these conditions.

Al tomare et al. [ALTOMARE] also addressed this issue and made sone additional strong arguments against extrapolating these data. They argue that these data were collected by measuring the leaching of relatively amall saples for a few hundred days and, therefore, that it is dangerous to apply them to full-size waste canisters over several hundred or thousand years. Because the penetration of water into concrete is extremely slow (Section III.B), once the iodine close to the surface is depleted, the leaching will - low down. It has been shown by [HATTA] that it takes sea water 1 y to penetrate $1 \mathrm{~cm}$ into a concrete block. As the readily accessible iodine near the surface is depleted, the inverse dependency of volume to surface area given in Eq. III-32 would be expected to break down due to the depth-of-penetration effects. 
In spite of this criticism, Altomare et al. [AlTOMARE]

used these ORNL data for distilled water:

$$
D_{e}=1.9 \times 10^{-4} e^{-4163 / T} \mathrm{~cm}^{2} / \mathrm{s}
$$

(T 18 in K) to project to a full-acale waste-disposal situation. This diffusivity translates into a penetration rate of $1 \times 10^{-2} \mathrm{~cm} / \mathrm{y}$ based on the specimen size tested. The projected time of complete lodine leaching from a cubic waste container $2.3 \mathrm{~m}$ on a side filled with $6000 \mathrm{~kg}$ of concrete containIng 10\% lodine was calculated to be $1.7 \times 10^{4} \mathrm{y}$. Even with all these approximations, it is obvious that this time is insignificant compared to $1.7 \times 10^{8} y$, the ten half-lives of decay necessary to reduce the amount of 129 I to less than $0.1 \%$ of 1 ts initial quantity.

Researchers at ORNL also studied, to a limited extent, the effect of concrete additives on the leaching of lodine $\mathrm{Ba}\left(\mathrm{IO}_{3}\right)_{2}$ in concrete ( 9.05 wt $z$ lodine). The additives tested were:

- $0.5 \% \mathrm{Na}_{2} \mathrm{StO}_{3}$

- $0.5 \% \mathrm{H}_{2} \mathrm{SIF}_{6}$

- 0.97 butyl stearate

- $1.2 \%$ polybutene 24 plus $0.5 \%$ aerosol or

- polybutene 20 coating of specimen

- 1.4\% PDO

All the additives tested but lead oxide caused some improvement in leach resistance for the concrete; the greatest improvement was found for butyl stearate, which lowered the leach rate by $n 3$ fold. Fluosilicic acid showed a great discrepancy for the leaching behavior of the two samples tested, which were prepared with an attenpt to formulate them identically. The average leach rate retardation was close to that of butyl stearate and, therefore, Clark et al. considered fluosilicic acid worthy of further study.

In leach tests (both static and dynamic) perforned at PNL on lodates and lodides in portland type III concrete, Burger et al. [BURGER$1981 \mathrm{~A}$ ] reached many of the same conclusions mentioned above. Their results can be summarlzed as follows:

(1) Approach to dynamic leach conditions increased the measured leach rates.

(2) H1gh temperatures increased leach rates.

(3) HIgh carbonate leachate concentrations decreased leach rates.

(4) Iodine loading In cement of more than 5 wt $\%$ Increased leach rates. 
(5) Low iodine compound solubility decreased leach rates (ABI, Ksp $=8.3 \times 10^{-17} \mathrm{vs}$. $\left.\mathrm{Ba}\left(\mathrm{IO}_{3}\right)_{2}, \mathrm{Ksp}=1.5 \times 10^{-9}\right)$.

(6) No additives or coatings had a significant effect on leach rates.

It is gignificant that the leach rate for iodine was measured to be within a factor of four for $\mathrm{Ba}\left(\mathrm{IO}_{3}\right)_{2}, \mathrm{Sr}\left(\mathrm{IO}_{3}\right)_{2}$, and $\mathrm{Ca}\left(\mathrm{IO}_{3}\right)_{2}$, while their solubility products increase in the order given above as $1.5 \times 10^{-9}, 3.3 \times 10^{-7}$, and $7.1 \times 10^{-7}$. Based on its lower solubility, $\mathrm{Ba}\left(\mathrm{IO}_{3}\right)_{2}$ would be predicted to leach at a much lower rate than $\mathrm{Ca}\left(\mathrm{IO}_{3}\right)_{2}$. A probable reason for the essentially equivalent leach rates of barium and calcium iodates is the sizable amount of sulfate ion in portland I.II cement (3.1 wt $\bar{z}--$ see section III. B for details). Because of the lower solubility of $\mathrm{BaSO}_{4}\left(n 2 \times 10^{-5} \mathrm{~g} / \mathrm{L}\right)$ than $\mathrm{Ba}\left(\mathrm{IO}_{3}\right)_{2}\left(\mathrm{n}_{3} \times 10^{-3} \mathrm{~g} / \mathrm{L}\right)$, at least some of the barium should be converted to $\mathrm{BaSO}_{4}$ during the preparation of the cement; the iodate becomes incorporated in the cement as the more soluble $\mathrm{Ca}\left(\mathrm{IO}_{3}\right)_{2}$.

In conclusion, studies of the leaching behavior of $\mathrm{Ba}\left(\mathrm{IO}_{3}\right)_{2}$ in concrete indicate that the rates of iodine leaching are much too high to contain ${ }^{129} I$ for the times necessary for its decay. No additives studied thus far have effectively altered this conclusion. The only significant parameter for reducing the leaching of iodine from barium iodate incorporated in concrete was the leachant. The use of waters containing various salts and minerals was determined to lower the diffusivity constant of iodine by 4-5 orders of magnitude from that measured in distilled water.

\section{(8) Radiation Studies of Barium Iodate in Concrete}

Based on the data presented in Section III.D.1, a concrete waste form containing 9.05 wt $z$ iodine $(757 \mathrm{I}-129)$ would receive a dose rate of $2.00 \mathrm{rad} / \mathrm{h}$. This dose rate corresponds to $5.6 \times 10^{-9} \mathrm{~J} / \mathrm{s}-\mathrm{g}$ concrete or $3.5 \times 10^{10} \mathrm{eV} / \mathrm{s} \cdot \mathrm{g}$ concrete.

Clark and Howerton studied how this self-irradiation would influence the radiolytic reduction of $\mathrm{Ba}\left(\mathrm{IO}_{3}\right)_{2}$ in concrete to the more soluble $\mathrm{BaI}_{2}$ [CLARK-1978,-1980]. To do this, they subjected concrete cylinders $\left(2.4-\mathrm{cm}\right.$ diameter by $2.5-\mathrm{cm}$ high) in a $60 \mathrm{Co}$ y flux of $4.4-5.3 \times 10^{15} \mathrm{eV} / \mathrm{s}-\mathrm{g}$ for a period of up to one week. The concrete specimens contained 9.05 wt $\approx$ iodine as $\mathrm{Ba}\left(\mathrm{IO}_{3}\right)_{2}$ and were cured for $28 \mathrm{~d}$ before use. The amount of $\mathrm{I}^{-}$present in the concrete specimens after various irradiation times was detected by conventional analytical techniques. No elemental $I_{2}$ was ever detected in any specimen.

The data obtained from analyses of irradiated and unirradiated concrete specimens are shown in Fig. III-10 as a plot of mg $\mathrm{I}^{-/ g}$ concrete va. irradiation time in days. The slope through the data corresponds to an iodide production of $7.22 \times 10^{-10} \mathrm{~g} \mathrm{I} \mathrm{I}^{-}$produced/s-g concrete. The non-zero intercept of the iodide content of the barium-iodate-incorporated 
concrete can be explained by the presence of reductants, primarily sulfite, in the portland cement. During the concrete-mixing process, the reaction

$$
3 \mathrm{So}_{3}{ }^{2-}+\mathrm{IO}_{3}^{-} \rightleftharpoons \mathrm{I}^{-}+3 \mathrm{So}_{4}^{2-}
$$

was taking place. Analysis of the cement confirmed the existence of enough $\mathrm{SO}_{3}{ }^{2-}$ to produce the iodide found in the unirradiated concrete specimen.

The Iinearity of the data of Fig. III-10 implies that any back reaction is negligible. The slope of this line predicts a $G$ value for the radiolytic reduction of iodate to iodide of $0.083 \mathrm{I}^{-}$ions $/ 100 \mathrm{eV}$. Based on the self-irradiation of $\mathrm{I}-129$ as $\mathrm{Ba}\left(\mathrm{IO}_{3}\right)_{2}$ in concrete of $3.47 \times 10^{10} \mathrm{eV} / \mathrm{s}-\mathrm{g}$ concrete, $2.1 \times 10^{-4 \%}$ of the $\mathrm{IO}_{3}^{-}$would be converted to $\mathrm{I}^{-}$per year. In 1000 $y$, only $0.21 \%$ of the iodate would be converted to iodide--a trivial amount compared to the $\mathrm{IO}_{3}{ }^{-}$that would be leached from the concrete.

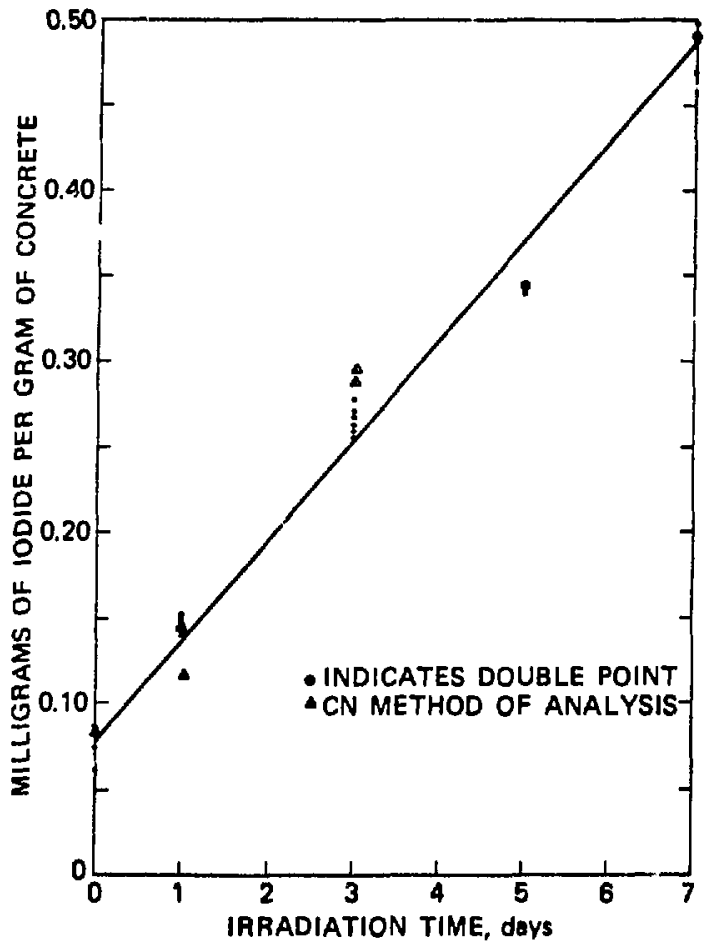

Fig. III-10. Radiolytic Reduction of Iocate to Iodide in a Barium Iodate Concrete Containing 9.05 wt 7 Iodine [CLARK-1980]. 


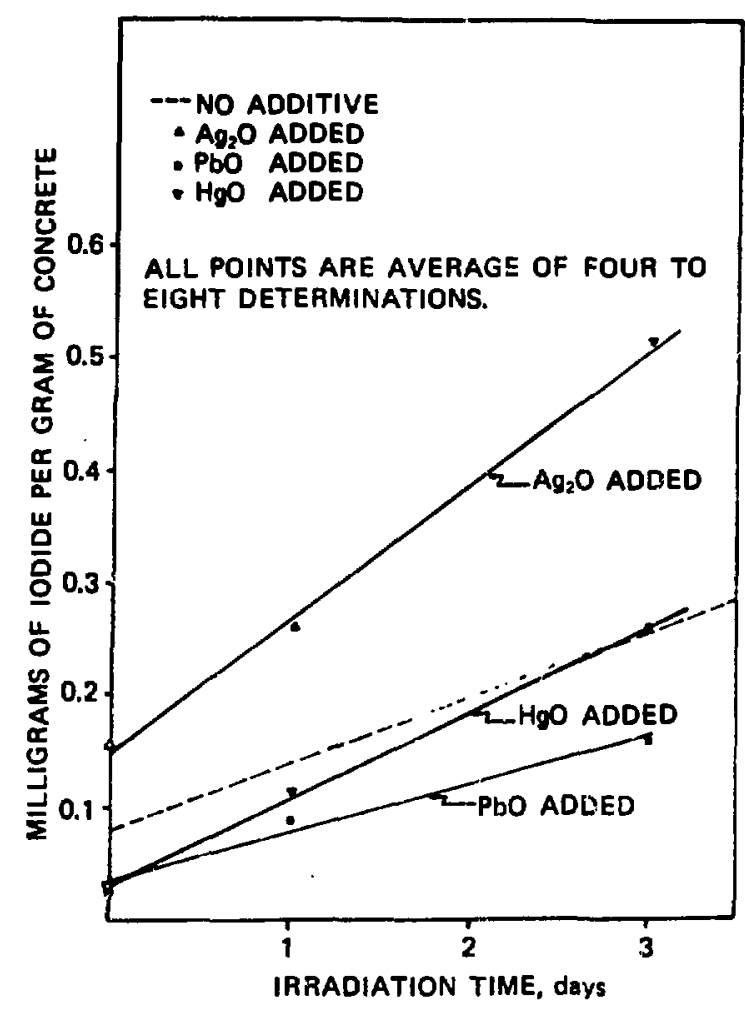

Fig. III-11. Ef fect of the Addition of 1.8 wt $Z$ of $\mathrm{Ag}_{2} \mathrm{O}$, $\mathrm{HgO}$, or $\mathrm{PbC}$ on the Radiolytic Reduction of Iodate to Iodide in Barium-Iodate Concrete Containing 9.05 wt $\%$ Iodine [CLARR-1980].

These same researchers also measured the effect of adding three oxides of metals that form low-solubility iodide salts ( $\mathrm{Ag}_{2} \mathrm{O}$, $\mathrm{HgO}_{\mathrm{O}}$, and $\mathrm{PbO})$. The data for those studies are presented in Fig. III-11. The G values caiculated from the data of Fig. III-11 are presented in Table III-19. Both $\mathrm{Ag}_{2} \mathrm{O}$ and $\mathrm{HgO}$ appear to increase the $\mathrm{G}$ value for the formation of $\mathrm{I}^{-}$from $\mathrm{IO}_{3}{ }^{-}$, while $\mathrm{PbO}$ decreases it slightly. The acceleration of iodide formation due to the presence of $\mathrm{Ag}_{2} \mathrm{O}$ seems certain, but the modest decrease and increase in iodine formation shown for $\mathrm{PbO}$ and $\mathrm{HgO}$, respectively, are uncertain within the analytical limits of the iodide measurement.

In conclusion, the effects of self-irradiation on the reduction of ${ }^{129} \mathrm{IO}_{3}-$ ion to $129 \mathrm{I}^{-}$is negligible when compared to predicted leaching of iodine from $\mathrm{Ba}\left(\mathrm{IO}_{3}\right)_{2}$ incorporated in concrete. Moreover, the addition of $\mathrm{Ag}_{2} \mathrm{O}$, $\mathrm{HgO}$, and $\mathrm{PbO}$ to the concrete will have a negligible effect on the already negligible radiolysis reaction. 
Table III-19. Ef fect of Additive on the $G$ Values for the Production of $\mathrm{I}^{-}$ Ion from $\mathrm{Ba}\left(\mathrm{IO}_{3}\right)_{2}$ in Concrete (additive concentration in concrete $=1.4$ wt $\%$ )

\begin{tabular}{cc}
\hline Additive & G Value, $I^{-}$io: $/ 100 \mathrm{eV}$ \\
\hline none & 0.083 \\
$\mathrm{Ag}_{2} \mathrm{O}$ & 0.151 \\
$\mathrm{HgO}$ & 0.105 \\
$\mathrm{PbO}$ & 0.060 \\
\hline
\end{tabular}

b. Silver Sorbents

\section{(1) General Considerations}

(a) Properties of Silver-Exchanged or Silver-NitrateImpregnated Sorbents

The use of: silver sorbents to collect I-129 has been given much study over the last ten years and has been reviewed by [JUBIN, HOLLADAY-1979, and BURGER-1979A]. Once these sorbents are loaded with $129 \mathrm{I}$, there are three options for disposal of the collected iodine:

Option (1). Regeneration of the silver sorbents for reusa by removal of the : Sioiodine. The radioactive iodine can be either loaded on lead-exchanged zeolite for disposal by options (2) or (3) below, or can be chemically converted to $\mathrm{AgI}$ or $\mathrm{Ba}\left(\mathrm{IO}_{3}\right)_{2}$ for disposal in concrete [ CHIKAILA-1982, ALTOMARE, THOMAS, JUBIN, HOLLADAY-1979, MURPHY-1977].

Option (2). Direct disposal of the iodine-loaded solid sorbent in metal canisters for long term disposal [BURGER-1979A, -1981A, -1981B; PENCE-1974; CHIKALLA-1980; and WOOD].

Option (3). Encapsulation of the solid sorbent into concrete for long-term disposal [BURGER-1979A, -1981A, -1981B; CHIKALLA-1980, $-1981 A$, -1981B, -1981C; PLATT-1980; BEONE].

Each of these options will be discussed in detail in the following sections. Before these disposal options are discussed, it seems appropriate to discuss pertinent chemical and physical characteristics of the silver sorbents being considered for the collection and disposal of iodine-129. The three most studied types are two silver-exchanged zeolites, silverexchanged faujasite ( $A g X$ ) and silver-exchanged mordenite ( $A g Z$ ), and a silver nitrate-impregnated amorphous silicic acid (AC-6120, commercially available, is the most researched of this type). 
The silver-exchanged faujasite most studied is one prepared fron Linde-type $13 \mathrm{X}$ molecular sieve. This material is conmercially available from Linde as the sodium exchanged form and can be easily converted to the silver form. This zeolite is a high-porosity material with three types of channels running through it. The faujasite unit cell is described by [BRECK] as $\left\{\left(\mathrm{Na}_{2}, \mathrm{~K}_{2}, \mathrm{Ca}, \mathrm{Mg}\right)_{29.5}\left[\left(\mathrm{AlO}_{2}\right)_{59}\left(\mathrm{SiO}_{2}\right)_{133}\right] \cdot 235 \mathrm{H}_{2} \mathrm{O}\right\}$. The unit cell of the zeolite $X$ is designated as $\left(\mathrm{Na}_{86}\left[\left(\mathrm{AlO}_{2}\right)_{86}\left(\mathrm{SiO}_{2}\right)_{106}\right] \cdot 264 \mathrm{H}_{2} \mathrm{O}\right)$. Linde's synthetic zeolite-X has the formulation $\left[(0.83 \pm 0.05) \mathrm{Na}_{2} \mathrm{O} \cdot \mathrm{Al}_{2} \mathrm{O}_{3} \cdot(2.48 \pm 0.03)\right.$ $\mathrm{SiO}_{2} \cdot \mathrm{nH}_{2} \mathrm{O}$ ? [JUBIN].

Mordenite has only about one third of the ion-exchange capacity of faujasite because of the much higher silica-to-alumina ratio of its structure. This higher $\mathrm{SiO}_{2} / \mathrm{Al}_{2} \mathrm{O}_{3}$ ratio has the beneficial effect, however, of increasing its hardness and resistance to acid decomposition [JUBIN]. These attributes appear to be important factors in the much greater capacity for regeneration of iodine fixation of $\mathrm{AgZ}$ Vs. that of $\mathrm{AgX}$. The unit cell of natural mordenite has the chemical composition $\mathrm{Na}_{8}\left[\left(\mathrm{AlO}_{2}\right)_{8}\left(\mathrm{SiO}_{2}\right)_{40}\right] \cdot 24 \mathrm{H}_{2} \mathrm{O}$ [BRECK]. Zeolon-900, sold by the Norton Company, is a self-bonded synthetic mordenite with the chemical formulation $\left(\mathrm{Na}_{2} \mathrm{O}\right)_{4} \cdot\left(\mathrm{Al}_{2} \mathrm{O}_{3}\right)_{4} \cdot\left(\mathrm{SiO}_{2}\right)_{40} \cdot 24 \mathrm{H}_{2} \mathrm{O}$. The silver ions that are exchanged into these mordenites can be converted to a metallic form by pretreating the $\mathrm{Agz}$ with $\mathrm{H}_{2}$ gas at $500^{\circ} \mathrm{C}$ for $216 \mathrm{~h}$ [BURGER1981B]. Experiments have shown that the metalic silver mordenite $\mathrm{Ag}^{\circ} \mathrm{Z}$ has a higher capacity for iodine chemisorpition than AgZ [JUBIN].

Table III-20 1ists several physical parameters of Linde $13 \mathrm{X}$ and Zeolon 900 molecular sieves important to their use in the fixation of iodine-129. Table III-21 shows the volume distribution (in units of voime percent) in terms of a single zeolite particle and in terms of a bed (or canister) of zeolite particles. Breck [BRECK] makes the important point that the interpellet void in Table III-21 is an equilibrium value. At initial packing the particles tend not to be as densely packed, and the void volume is closer to 38 vol $z$.

For long-term storage of ${ }^{129} \mathrm{I}$, silver-nitrateimpregnated materials offer the advantage that silver iodide is clearly the product of their fixation reaction; the iodine is, therefore, held very tightly to the waste form as insoluble silver iodide (the solubility of AgI vs. temperature is shown in Fig. III-12). Another important factor is that these materials cost only $w / 10$ as much as the molecular sieve materials [HOLLADAY1979]. According to [JUBIN], there have been three commercial types of this material tested:

GX-135 (North American Carbon Company). This silver nitrate containing aluminum silicate was highly effective at fixing iodine from both $\mathrm{I}_{2}$ and $\mathrm{CH}_{3} \mathrm{I}$ in tests at ORNL, but was discontinued because of the handling problems caused by its fine mesh size $(8 \times 16$ mesh) [JUBIN].

H-151 (Aluminum Company of America). There is a limited mount of work on the use of this high-alumina-content (90\%) material impregnated by $\mathrm{AgNO}_{3}$ and other nitrate salts: only silver nitrate was found to bind iodine irreversibly. Table III-22 gives the physical specification of this material [JUBIN]. 
Table III-20. Propertles of Comerclally Avallable Molecular Sieves, Linde $13 \mathrm{X}$ and Zeolon 900 [BRECK]

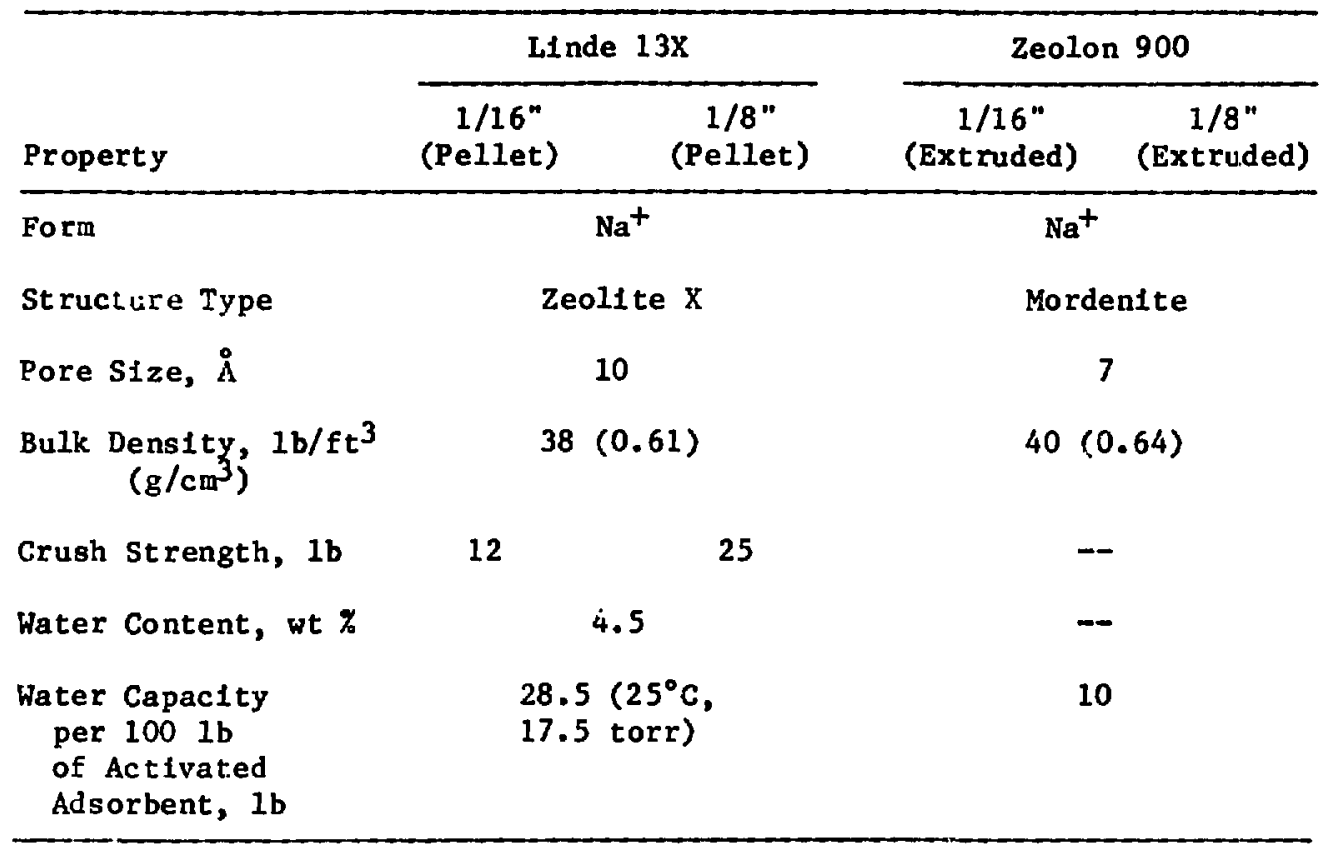

Table III-21. Volume Distribution in a Single Molecular Sieve Pellet and In a Bed of Molecular Sieve Pellets [BRECK]

\begin{tabular}{|c|c|c|c|c|}
\hline \multirow[b]{2}{*}{ Constituent } & \multicolumn{2}{|c|}{ Pellet, vol $\pi$} & \multicolumn{2}{|c|}{ Bed, vol \% } \\
\hline & $\begin{array}{l}1 / 16^{\prime \prime} \\
\text { s1ze }\end{array}$ & $\begin{array}{l}1 / 8 " \\
\text { size }\end{array}$ & $\begin{array}{c}\text { 1/16" } \\
\text { pellets }\end{array}$ & $\begin{array}{c}1 / 8^{\prime \prime} \\
\text { pe1lets }\end{array}$ \\
\hline Intraciystal Vold & 28.1 & 28.8 & 19.1 & 19.6 \\
\hline Intercrystal Void & 33.4 & 31.5 & 22.7 & 21.4 \\
\hline $\begin{array}{l}\text { Solid Portion of } \\
\text { Crystal }\end{array}$ & 29.2 & 30.1 & 19.9 & 20.5 \\
\hline $\begin{array}{l}\text { Solid Portion of } \\
\text { Binder }\end{array}$ & 9.3 & 9.6 & 6.3 & 6.5 \\
\hline Interpellet Vold & - & $-\infty$ & 32.0 & 32.0 \\
\hline
\end{tabular}




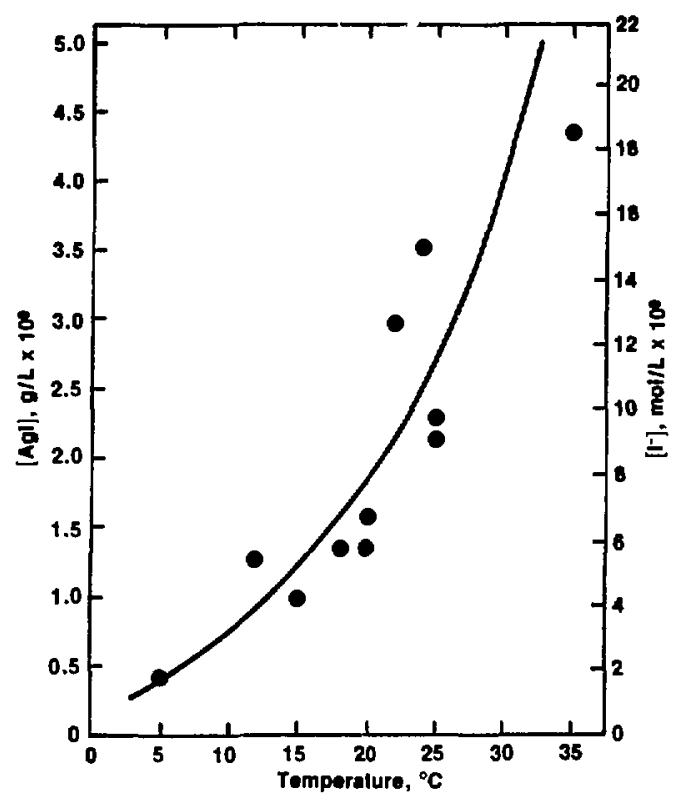

F1g. III-12. Solubility of AgI v8. Temperature [MEYER].

Table III-22. Spectfication of Alumina-Base Adsorbent: Alcoa Alumina H-151 [JUBIN]

\begin{tabular}{|c|c|}
\hline \multicolumn{2}{|l|}{ Composition, $\%$} \\
\hline $\mathrm{Al}_{2} \mathrm{O}_{3}$ & 90.0 \\
\hline $\mathrm{Na}_{2} \mathrm{O}$ & 1.4 \\
\hline $\mathrm{Fe}_{2} \mathrm{O}_{3}$ & 0.1 \\
\hline $\mathrm{SHO}_{2}$ & 1.7 \\
\hline Loss on Ignition $\left(1100^{\circ} \mathrm{C}\right), \pi$ & 6.0 \\
\hline Surface area, $\mathrm{m}^{2} / \mathrm{g}$ & 390 \\
\hline Bulk density (packed), $1 \mathrm{~b} / \mathrm{ft}^{3}$ & 53 \\
\hline Spectfic gravity & 3.: \\
\hline Particle sizes, cm & 0.34 and 0.12 \\
\hline
\end{tabular}


AC-6120 (United Catalysts, Inc.). Silver-nitrateimpregnated silicic acid has been developed by the Federal Republic of Germany as a non-regenerable solid sorbent for iodine-129 collection and disposal. This material, which has a silver content of 7-12 wt $\%$, has been used successfully to remove iodine from DOG at the Reprocessing Plants in Karlsruhe, Germany, and Centre de Marcoule, France [BURGER-1979A].

\section{(b) The Stability of Silver Sorbents to Loss of Iodine}

Maximum and practical loading limits of iodine per gram of sorbent are important for the collection process. Another equally important parameter for disposal of iodine is the amount of iodine that is chemically and physically bound to the sorbent. Chemically bound iodine will have an expected chemical stability and insolubility as good as or better than those of silver iodide. Physically bound iodine is expected (1) to have much inferior properties to those of $\mathrm{AgI}$ and (2) to be much more susceptible to leaching from the waste form. Table III-23 tabulates the iodine loading capacities of several sorbents in terms of their theoretical capacities and in terms of the practical concern of keeping collection efficiency of iodine from the DOG above $99.9 \%$.

The higher loading capacity of $\mathrm{AgX}$ makes it appear much more attractive than AgZ or AC-6120. Unfortunately, collection of iodine is only the short-term problem. When one considers the long-term problem of protecting the biosphere from high concentrations of I-129, the virtues of $\mathrm{AgZ}$ and $\mathrm{AC}-6120$ become apparent. Workers [BURGER-1981A, -1981B; SCHEELE-1981] have determined that much of the iodine (>50\%) sorbed on AgX was removable by Soxhlet extraction using carbon tetrachloride, tetrachloroethylene, toluene, or hexane; in contrast, no iodine could be stripped from AgZI by this same technique. This finding suggests a wore stable fixation of iodine by AgZ than AgX. However, both AgXI and AgZI release iodine when heated [BURGER1982B]. Because the chemical form of iodine in the structure of AC-6120 is certainly $\mathrm{AgI}$, it would also be expected to not release iodine by Soxhlet extraction.

Thermal measurements (TGA and DSC) on AgX, AgZ, $\mathrm{Ag}^{\bullet} \mathrm{Z}$, and $\mathrm{AC}-6120$ loaded with iodine show that the sorption of iodine by those sorbents is very complex, and there are many furms of iodine in their structures that cannot be identified as simple silver compounds. Even AC-6120 does not correspond exactly in its thermal behavior to $\mathrm{AgNO}_{3}$ and $\mathrm{AgI}$. Figure III-13 shows the results of the thermogravimetric analyses up to $1000^{\circ} \mathrm{C}$ of $A g Z, A g^{\circ} \mathrm{Z}, \mathrm{AgX}$, and $\mathrm{AC}-6120$ loaded with iodine to $50 \%$ of their maximum capacities. All the weight $108 \mathrm{~s}$ is not $I_{2}$; much of the low-temperature weight loss is water, and some volatilization of AgI along with iodine may have been seen at higher temperatures. It appears that no iodine is lost from AC-6120; rather, the measured weight loss is due to the decomposition of nitrate ion [BURGER-1981A, -1981B; CHIRALLA-1981A; SCHEELE-1981].

Thermogravimetric anaiyses of several samples of AgZ with varying loadings of iodine have shown that the final iodine content for all loadings tends toward $45 \mathrm{mg} \mathrm{I/g} \mathrm{AgZ}$ at $1000^{\circ} \mathrm{C}$. When the equilibration of the sorbent was reached slowly, this stable fraction appeared to be constant whether the iodine was loaded from a continuous stream of $\mathrm{I}_{2}$ or $\mathrm{CH}_{3} \mathrm{I}$. Figure III-14 shows the comparable thermal behavior of two samples of AgZ loaded to different degrees by a continuous feed over three weeks of either $\mathrm{I}_{2}$ or $\mathrm{CH}_{3} \mathrm{I}$. 
Table III-23. Maximun and Practical Iodine Loading Capacities of SIlver and Lead Sorbents [JUBIN]

\begin{tabular}{lcc}
\hline Sorbent & $\begin{array}{c}\text { Maximum (Theoretical) } \\
\text { Sorption, mg I/g }\end{array}$ & $\begin{array}{c}\text { Practicala Sorption } \\
\text { for Collection, mg I/g }\end{array}$ \\
\hline $\mathrm{AgX}$ & 429 & 220 \\
$\mathrm{PbX}$ & 437 & 390 \\
$\mathrm{AgZ}$ & 237 & 190 \\
$\mathrm{PbZ}$ & 247 & $398 \mathrm{~b}$ \\
$\mathrm{AC}-6120$ & & \\
$(7 \mathrm{wt} \times \mathrm{Ag})$ & 73 & 10 \\
$\mathrm{AC}-6120 / \mathrm{H}_{1}$ & & \\
$(12 \mathrm{wt} \mathrm{Ag})$ & 143 & 10 \\
$\mathrm{H}-151$ & 88.2 & 5 \\
$\mathrm{GX}-135$ & - & 2 \\
\hline
\end{tabular}

To keep collection efficlencies above $99.9 \%$.

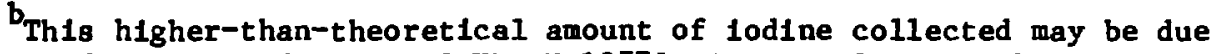
to formation of $\mathrm{H}_{2} \mathrm{PbI}_{4}$ [MURPHY-1977]; $1 \mathrm{t}$ may also just be wrong (discussed later in this section).

In that same figure is the thermal analysis curve of a sample of Agz loaded In a batch mode over $24 \mathrm{~h}$. The sample for this curve begins 1ts loss of lodine at the same temperature, but has less lodine at $1000^{\circ} \mathrm{C}$ than the other two samples shown and the many others tested [SCHEELE-1981].

The relative stability to lodine loss of leadexchanged zeolites was reported by [MURPHY-1977], who measured the vapor pressure of lodine over lead-exchanged zeolites loaded with lodine to 38 wt $\%$ for $\mathrm{Pb}{ }^{\circ} \mathrm{XI}$, to 40 wt $\mathrm{Z}$ for $\mathrm{PbXI}$, and to $38 \mathrm{wt} \mathrm{Z}$ for $\mathrm{PbZI}$ v8. temperature. These lodine-loaded lead zeolites were prepared from the reaction of the leadexchanged zeolites with $\mathrm{HI}$. The effects of hydrogen, nitrogen, and alr atmospheres on the $I_{2}$ vapor pressures were also studled. The results of this study, presented in Table III-24, are somewhat in doubt because of conflicting reporting of these data in this report. It is also not clear how they achleved 38 wt $\%$ loading of lodine on $\mathrm{Pb}^{\circ} \mathrm{X}$ when other data in this same report show a maximum loading of only $192 \mathrm{mg} \mathrm{HI} / \mathrm{g}$ zeolite $\left(19\right.$ wt $\mathrm{z}$ ) of lodine on $\mathrm{Pb}^{\circ} \mathrm{X}$. Their reporting of over $100 \%(161 \%)$ of the theoretical loading of lodine onto $\mathrm{PbZ}$ is disturbing.

It has been mentioned by several sources that the solubilfty of lodide in sllver-exchanged and silver-nitrate-1npregnated sorbents should be even lower than that of silver lodide [JUBIN, ALTOMARE], but no data have been found to verify th1s. From the Soxhlet extraction and 
a.

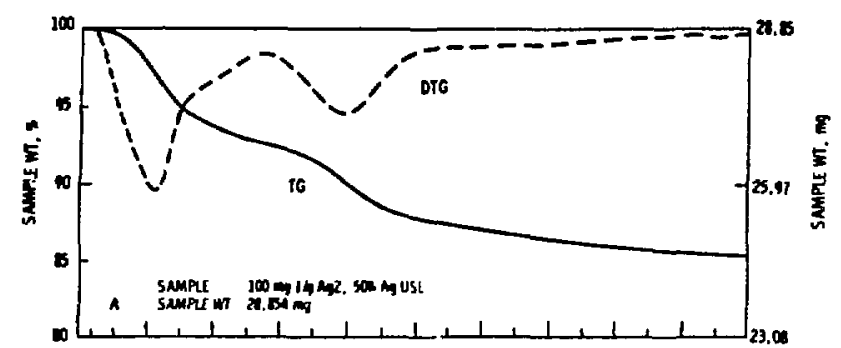

b.

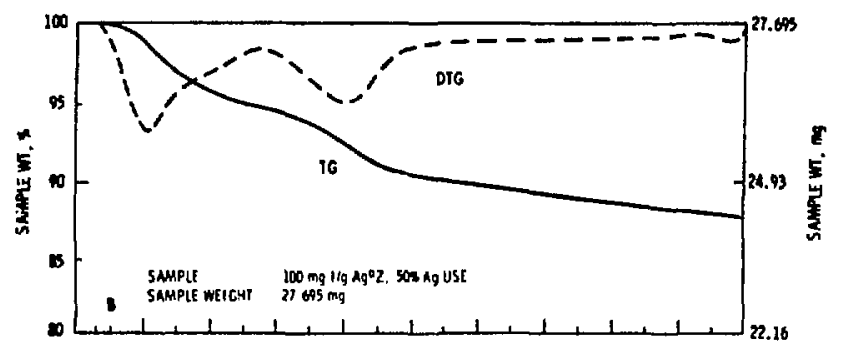

c.

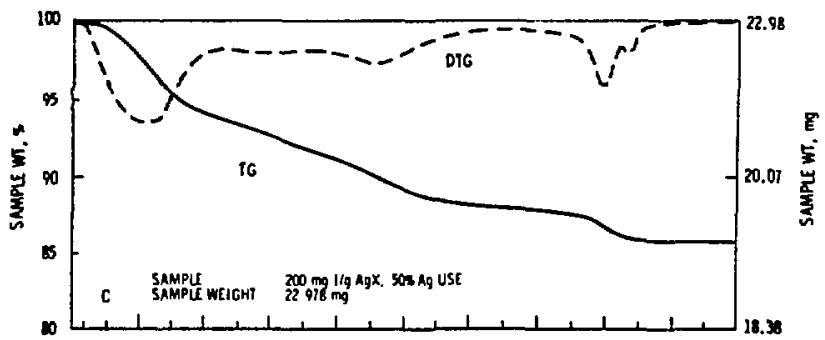

d.

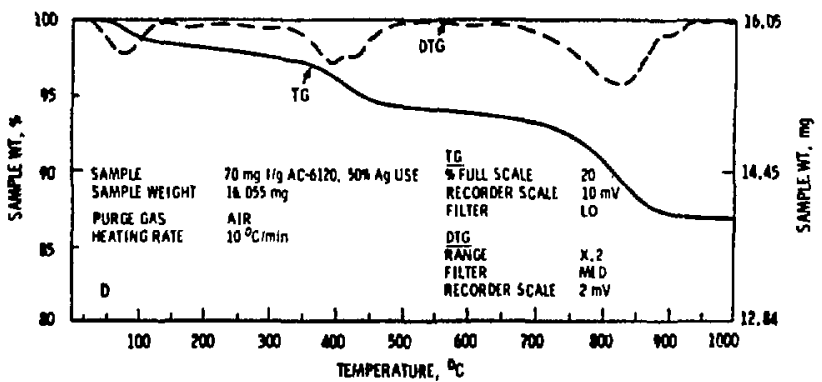

Fig. III-13. Thermogravimetric Analyoes for

(a) $\mathrm{AgZ}$, (b) $\mathrm{Ag}^{\circ} \mathrm{Z}$, (c) $\mathrm{AgX}$, and (d) AC-6120 (all with $50 \%$ capacity loadings of lodine; TG = welght loss; DTG = differential weight loss $\Delta W / \Delta T$ ) [BURGER-1981B] 


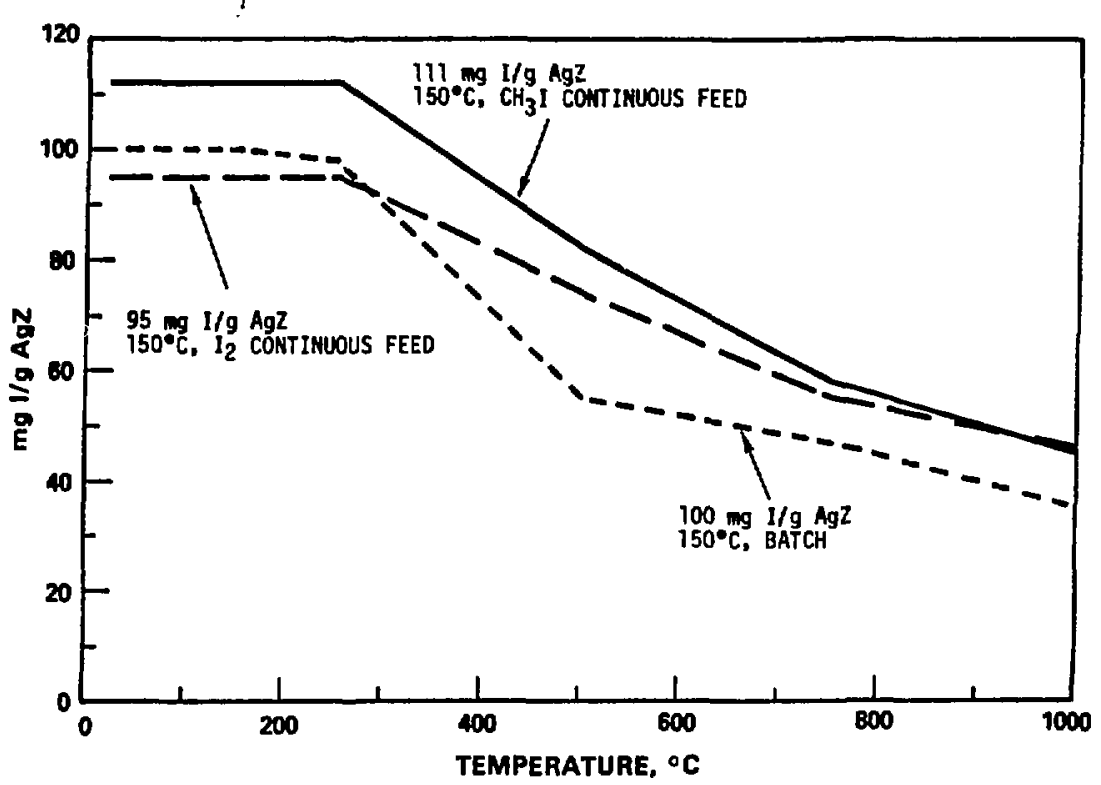

Fig. IiI-14. Effect of Iodine Loading Rate and Species on the Thermal Release of Iodine from AgzI [SCHEELE-1981]. 
Table III-24. Extrapolated Vapor Pressure of $I_{2}$ above $\mathrm{PbXI}, \mathrm{PbZI}$, and $\mathrm{Pb}^{\bullet}$ in $\mathrm{H}_{2}, \mathrm{~N}_{2}$, and $\mathrm{Air}$ Atmosphere at $20^{\circ} \mathrm{C}$ [MURPHY-1977]

\begin{tabular}{lccc}
\hline & \multicolumn{3}{c}{ Vapor Pressure, atm } \\
\cline { 2 - 4 } Sorbent & in air & in $\mathrm{H}_{2}$ & in $\mathrm{N}_{2}$ \\
\hline $\mathrm{PbZI}$ & $4.7 \times 10^{-6}$ & $4.5 \times 10^{-6}$ & $1.9 \times 10^{-6}$ \\
$\mathrm{~Pb}^{\circ} \mathrm{XI}$ & $9 \times 10^{-19}$ & $8.7 \times 10^{-19}$ & $2.5 \times 10^{-12}$ \\
$\mathrm{PbXI}$ & $4.0 \times 10^{-8}$ & $4.0 \times 10^{-11}$ & $4 \times 10^{-13}$
\end{tabular}

thermal studies discussed previously and from the leach data yet to be discussed, it seems this observation is certainly not true, at ieast for the majority of iodine fixed in these sorbents. A measurement of the solubility of $\mathrm{PbI}_{2}$ from $\mathrm{PbXI}$, however, does show that the solubility of iodide is less than expected from the solubility of $\mathrm{PbI}_{2}$ in water [THOMAS]. These researchers measured a solubility of $26 \mathrm{mg} I / 100 \mathrm{~mL}$ water at room temperature. The solubility of iodide in water as $\mathrm{PbI}_{2}$ at $20^{\circ} \mathrm{C}$ is $35 \mathrm{mg} \mathrm{I} / 100 \mathrm{~g} \mathrm{H} \mathrm{H}_{2} \mathrm{O}$ [DEAN]. This finding is an indication that the solubility of $\mathrm{PbI}_{2}$ is a factor in the case of lead-exchanged zeolites.

\section{(2) Disposal Options}

\section{(a) Regeneration of the Silver Sorbent}

of the silver sorbents mentioned in this text, only silver-exchanged mordenite appears to be regenerable without great $108 \mathrm{~s}$ of capacity [JUBIN, BURGER-1979A, and THOMAS]. According to [THOMAS], after five regeneration cycles at 400 to $500^{\circ} \mathrm{C}$, the iodine loading capacity of AgX dropped by two fold. At $600^{\circ} \mathrm{C}$, its capacity dropped three fold after 3 cycles. No decline was seen at all for $\mathrm{AgZ}$ after the same tests. After 13 recycles the capacity of $\mathrm{AgZ}$ was down by $20 \%$. The apparent reason for the loss of capacity for iodine by these zeolites is a collapse in pore structure caused by the recycle. The higher silica content of mordenite leads to a harder structure, more resistant to pore collapse.

If the sorbent is regenerated with the silverexchanged mordenite, there is still a choice to be made: should the radioactive hydrogen iodide gas be trapped on a lead-exchanged zeolite or should it be scrubbed into an aqueous solution to be converted to an insoluble form, preamably $\mathrm{Ba}\left(\mathrm{IO}_{3}\right)_{2}$ ? Some experimental work has been performed on the scrubb ing of HI by various aqueous phases and such a procedure is possible [PLATT1979A, $-1979 \mathrm{~B},-1979 \mathrm{C}]$. The other option, collection by lead-exchanged zeolites has had a great deal móre study and also seems quite possible. Figure III-15 is a block diagram for this process. If this option is selected, the disposal form for long-term storage is (1) PbXI or PbZI with no matrix or (2) encapsulation in a concrete matrix. These alternatives will be discussed in the following sections. 


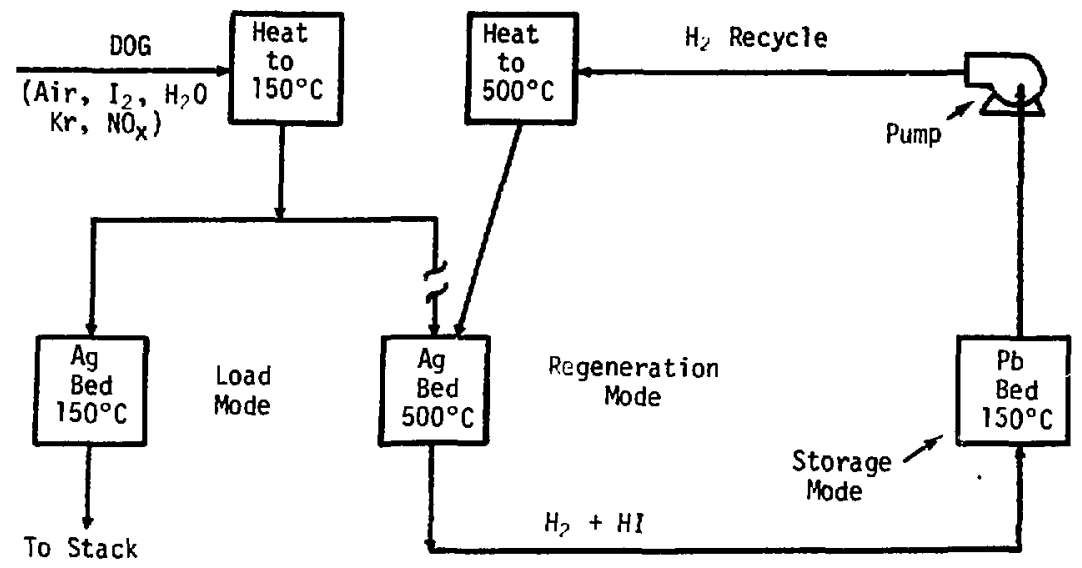

$$
\begin{array}{ll}
\text { Load Mode Reaction: } & 2 \mathrm{Ag}^{\circ}+\mathrm{I}_{2} \rightleftharpoons 2 \mathrm{AgI} \\
\text { Regeneration Mode Reaction: } & 2 \mathrm{AgI}+\mathrm{H}_{2} \rightleftharpoons 2 \mathrm{Ag}^{\circ}+2 \mathrm{HI} \\
\begin{array}{l}
\text { Storage Made Reaction } \\
\text { Approximated by: }
\end{array} & \mathrm{PbO}+2 \mathrm{HI} \rightleftharpoons \mathrm{PbI}_{7}+\mathrm{H}_{2} \mathrm{O}
\end{array}
$$

Fig. III-15. Block Diagram of Iodine Recovery Process (derived from [THOMAS])

(b) Ag-Exchanged, AgNO 3 -Impregnated, or Pb-Exchanged

According t.o Pence and Staples [PENCE-1974], "Processing of the iodine-laden adsorbent from the primary system to obtain a more concentrated form would not appear to be necessary or desirable." They go on to say: "The product should be ideally suited for long-term storage, provided excess $\mathrm{NO}_{2}$ and moisture are purged from the adsorbent prior to packaging. Because the decay energy of I-129 is 80 low, a negligible amount of decay heat will be generated." Wood and Richardson [WOOD] also consider disposal of iodine-loaded sorbents in a container to be an option.

To calculate the specific activity of I-129 in this waste form, one must assume that the excharige of silver ion for sodium ion and the subsequent sorption of iodine does not increase the bulk volume of the material, only its density; this assumption is clearly compatible with what is known about these materials. The maximum and practical loadings of each sorbent are listed in Table III-23. The bulk denaity of zeolytic sorbents was calculated by correcting for (1) the higher mass of silver and lead ions vs. that of sodium ion and (2) the additional mass increase caused by iodine sorption. The silver-nitrate-impregnated sorbents were corrected for the greater ans of the iodide ion ve. that of the nitrate ion. Tabulated for each potential wate form in Table III-25 are the calculated bulk densities, amount of sorbent necessary to store the iodine produced in a model reprasessing plant of $1500 \mathrm{MTHM} / \mathrm{y}$, and the specific activity of the waste form. 
Table III-25. A Comparison of the Waste Disposal Forms for Various Solid Sorbents Alone or Encapsulated In Concrete

\begin{tabular}{|c|c|c|c|c|c|c|c|c|c|c|}
\hline \multirow[b]{2}{*}{ Sorbent } & \multicolumn{2}{|c|}{$\begin{array}{c}\text { Bulk Density of } \\
\text { Iodime-Loaded Sorbent, } \\
\mathrm{mT} / \mathrm{m}^{3}\left(\mathrm{Ib} / \mathrm{ft}^{3}\right)\end{array}$} & \multicolumn{2}{|c|}{$\begin{array}{l}\text { Mess to Contain } \\
625 \mathrm{~kg} \text { of lodine, " } \\
\end{array}$} & \multicolumn{2}{|c|}{$\begin{array}{l}\text { Volume to Contain } \\
625 \mathrm{~kg} \text { of lodine, }=\mathrm{m}^{3}\end{array}$} & \multicolumn{2}{|c|}{$\begin{array}{c}\text { Specific } \\
\text { setivity, } \mathrm{Ci} / \mathrm{MT}\end{array}$} & \multicolumn{2}{|c|}{$\begin{array}{c}\text { Specific } \\
\text { Activity, }{ }^{b} \mathrm{Ci} / \mathrm{m}^{3}\end{array}$} \\
\hline & Maxieunc & Praeticald & Maxinumc & Practicald & Maximume & Practicald & Maximunc & Prseticald & Maximunc & Practicald \\
\hline $\operatorname{Ag} x$ & $1.12(70)$ & $0.99(62)$ & 1.54 & 3.00 & 1.38 & 3.03 & 52.8 & 27.1 & 58.9 & 26.8 \\
\hline $\mathbf{P b x}$ & $1.12(70)$ & $1.02(64)$ & 1.51 & 1.69 & 1.35 & 1.66 & 53.8 & 48.1 & 60.2 & 48.9 \\
\hline 482 & $1.02(64)$ & $0.99(62)$ & 2.78 & 3.47 & 2.73 & 3.50 & 29.2 & 23.4 & 29.8 & 24.4 \\
\hline $\mathbf{P b z}$ & $1.02(64)$ & $0.99(62) e$ & 2.67 & $3.30^{e}$ & 2.62 & $3.33^{e}$ & 30.4 & $24.6 e$ & 31.0 & $49.0^{e}$ \\
\hline$A C-6120^{E}$ & $0.88(55)$ & $0.85(53)$ & 9.04 & 66.0 & 10.3 & 77.6 & 9.0 & 1.2 & 7.9 & 1.0 \\
\hline 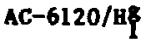 & $0.98(61)$ & $0.91(57)$ & 4.62 & 66.0 & 4.71 & 72.5 & 17.6 & 1.2 & 17.2 & 1.1 \\
\hline H-151 & $0.90(56)$ & $0.85(53)$ & 7.48 & 132.0 & 8.31 & 155.0 & 10.9 & 0.6 & 9.8 & 0.5 \\
\hline$G x-135 f$ & - & $0.85(53)$ & - & 330.0 & - & 388.0 & - & 0.02 & -- & 0.02 \\
\hline $\begin{array}{l}34 \text { wt } z \\
\text { AgzI in } \\
\text { concrete }\end{array}$ & 一 & $2.1(131)$ & -- & 11.5 & -- & 5.48 & - & 7.09 & -- & 14.8 \\
\hline $\begin{array}{l}20 \text { ut } z \\
\text { PbxI in } \\
\text { concrete } i\end{array}$ & -- & $2.1(131)$ & -- & 8.45 & - & 4.02 & -- & 9.62 & -- & 20.2 \\
\hline
\end{tabular}

The mount of iodine release projected from a $1500 \mathrm{MTHH} / \mathrm{y}$ reprocessing plant in one year [ALTOMARE].

byesed on $625 \mathrm{~kg}$ radioactive iodine $(75 \% 129 \mathrm{I})$ or $81.2 \mathrm{ci}$.

Asaming the aximu theoretical loading of iodine was loaded on the sorbent as $75 \%$ I-129 and $25 \%$ I-127.

dAsuming the practical loading lizit of iodine (Table III-22) was loaded on the sorbent as $75 \%$ I-129 and $25 \%$ I-:27.

Because there is uncertainty for the value of the practical loading of $\mathrm{HI}$ on $\mathrm{PbZ}, 200 \mathrm{mg}$ iodine/g was used based on the behavior of AsZ or $\mathrm{PbX}$.

The bulk density of $\mathrm{k}-15 \mathrm{l}\left(53 \mathrm{lb} / \mathrm{ft}^{3}\right)$ was used for this calculation.

${ }^{8}$ The greater concentration of the high-density silver nitrate was used to calculate a bulk density (hased on that of $11-151$ ) of 57 lb/ft ${ }^{3}$.

hThe AgzI is looded with 190 ag I/g AgZ, which is comparable to 160 wg I/g AgZI.

$i_{\text {The }} \mathrm{PbXx}$ is louded with $370 \mathrm{mg} \mathrm{I} / \mathrm{g} \mathrm{PbX}$. 
Another criterion that has been used in picking a disposal form for I-129 is its resistance to leaching of I-129 into the biosphere. There has been very little information discovered in the literature as a basis for comparing the leach resistance of the solid sorbents listed in Table III-23, these same waste forms in concrete, and $\mathrm{Ba}\left(\mathrm{IO}_{3}\right)_{2}$ encapsulated in concrete. Preliminary static leach studies by Scheele and Wiemers [CHIKALLA-1980] determined that after 28 d the silver sorbents studied (70\% loaded AgZI, AgXI, and AC-6120 and $95 \%$ loaded $\mathrm{Ag}^{\circ} \mathrm{ZI}$ ) had leached two to four orders of magnitude less of their iodine than comparable materials encapsulated in concrete. The fraction of iodine leached from these materials after $28 \mathrm{~d}$ varied from $<2.0 \times 10^{-7}$ to $2.0 \times 10^{-5}$. In later reports of this work [BURGER-1981A, -1981B, SCHEELE-1981], no additional data were presented; it was merely stated that there was "no improvement when placed in cement." However, [BURGER-1981A] states: "The solid sorbents considered are potentiai disposal forms as ised. However, granular or powder forms present handling problems in addicion to much lower resistance to leaching or volatilization. We believe immobilization in a monolithic form is desirable."

The statement on leach resistance does not seem to follow directly from the data presented in [CHIKALLA-1980], but the statement on handling problems of granular or powder forms is an important consideration.

No reports of the leach resistance of the lead zeolites were discovered in reviewing the literature, but, based on the ordersof-magnitude higher solubility of $\mathrm{PbI}_{2}$ compared to AgI, the lead zeolites would be expected to have orders-of-magnitude higher leach rates than the silver zeolites.

\section{(c) Disposal of Ag-Exchanged, $\mathrm{AgNO}_{3}$-Impregnated or Pb-Exchanged Sorbents in Concrete Matrix}

The loading levels of AgZI and $\mathrm{PbXI}$ in concrete reported by Burger et al. [BURGER-1981A] are $0.8 \mathrm{mmol} \mathrm{I} / 8$ dry concrete and $u 1$ mmol I/g dry concrete, respectively. These levels correspond to 234 wt $\%$ AgZI and 220 wt $\% \mathrm{PbXI}$ in cured concrete. The estimated density of the concrete is $2.1 \mathrm{MT} / \mathrm{m}^{3}$. The calculated waste volumes and specific activities of these potential waste forms found in Table III-25 are based on these values. Because of the 327 void volume of packed zeolites, the specific activity of zeolites in terms of $\mathrm{ci} / \mathrm{m}^{3}$ in concrete is not much lower than that of zeolites without the presence of concrete. The higher density of cement vs. that of air makes for large differences in specific activities between zeolite alone and zeolite in concrete when expressed in terms of $\mathrm{Ci} / \mathrm{MT}$.

The leach resistance of AgZI in concrete was measured to be about an order of magnitude greater than that for a comparable amount of $\mathrm{Ba}\left(\mathrm{IO}_{3}\right)_{2}$ in concrete in a dynamic leach test; in static leach tests, the leach rates of these two potential disposal forms were experimentally equivalent [BURGER-1981A]. The dynamic leach rate of pure AgI in concrete is a factor of 10 lower than that for AgZI. The higher leach rate for AgZI vs. that of AgI can be explained on the basis of the thermal analysis of Agz ohown that only $45 \mathrm{mg} \mathrm{I} / \mathrm{g} \mathrm{AgZ}$ is held as AgI; the rest of the $150 \mathrm{mg} \mathrm{I} / \mathrm{g} \mathrm{AgZ}$ is held in more labile forms. At the measured leach rate of $4 \times 10^{-6} \mathrm{~cm} / \mathrm{d}$, it would take $100 \mathrm{y}$ to leach $1 \%$ of the iodine from a typical 208-L monolith of AgZI encapoulated in concrete. 
When PbXI was added to cement, the mixture turned purple, indicating the hydrolysis of the lead-zeolite-iodide material with release of elemental iodine [BURGER-1981A]. Static leach tests for two samples showed how poor the leach resistance for this form is; after $5 \mathrm{~d}$ the normalized fraction of iodine released was $0.07-0.2 \mathrm{~cm}$ (a rate of $1-4 \times 10^{-2} \mathrm{~cm} / \mathrm{d}$ ).

Beone and Di stefano [BEONE] studied the physical characteristics of concrete containing several concentrations of AgX sorbents. The cement they studied was pozzolanic (approximate composition would be $80 \%$ portland I cement/20\% fly ash), which is more expensive than regular portland cements but has the advantages of high chemical resistance and a very high encapsulation capacity. The silver-exchanged zeolite they tested was LMX-13X (Union Carbide Europe). The concrete samples were cured in a $100 \%$ humidity environment and then allowed to air dry to a constant weight. Figure III-16 shows the rate of water loss during this drying period for several samples of differing composition; these various compositions are listed in Table III-26. The amount of water loss as well as the rate of water loss increase as the zeolite loadings are increased.

Figure III-17 shows the density of concretes at various loading levels of silver-exchanged zeolites. These densities are lower than the ones used for previous assumptions in this section because pozzolanic is a lower-than-average-density cement and the silver-exchanged zeolite was not loaded with iodine.

Beone and Di stefano [BEONE] also reported results of crush-strength studies of concrete-encapsulated, silver-exchanged zeolites. Their results, shown in Fig. III-18, show that crush strength decreases with increasing zeolite concentration. The decline in crush strength drops almost Iinearly with zeolite loadings of less than 35 wt \%; above this loading level, decline in crush stength with zeolite content becomes far more drastic.

These same researchers also tested the thermal resistance of zeolite-containing concretes with 31.8 wt \% zeolite (sample 5, Table III-26) by two methods. The first was a modified IAEA test for thermal resistance of radioactive material. The normal test called for heat ing the material at $800^{\circ} \mathrm{C}$ in air for $10 \mathrm{~min}$, but the researchers increased that time to $30 \mathrm{~min}$. The samples tested lost between 18 and $25 \%$ weight by water and/or $\mathrm{CO}_{2}$ and their surfaces were completely fissured. Carbon dioxide was fonned from the thermal decomposition of $\mathrm{CaCO}_{3}\left(\mathrm{CaCO}_{3}+\mathrm{CaO}+\mathrm{CO}_{2}\right)$. In the second test, the effect of localized thermal expansion was measured by placing the tip of a Bunsen flame to the concrete specimen for one minute. Two samples were tested. The first, a $65 \mathrm{~g}$ cylinder (sample 5), aged for 7 months prior to the test, lost 0.4 w 7 during the test. The second, $190 \mathrm{~g}$ (sample 5), aged for 2 months before the test, lost 1.3 wt $\%$ during the test. Both samples showed fissuring near the area of contact with the Bunsen flame.

Beone and $\mathrm{Di}$ Stefano [BEONE] conclude from their results that loading 1 imits for zeolite in concrete should not exceed 35 wt $\%$. In addition, they feel that the usc of additives to increase the concrete's strength and thermal resistance are necessary and should be studied. 


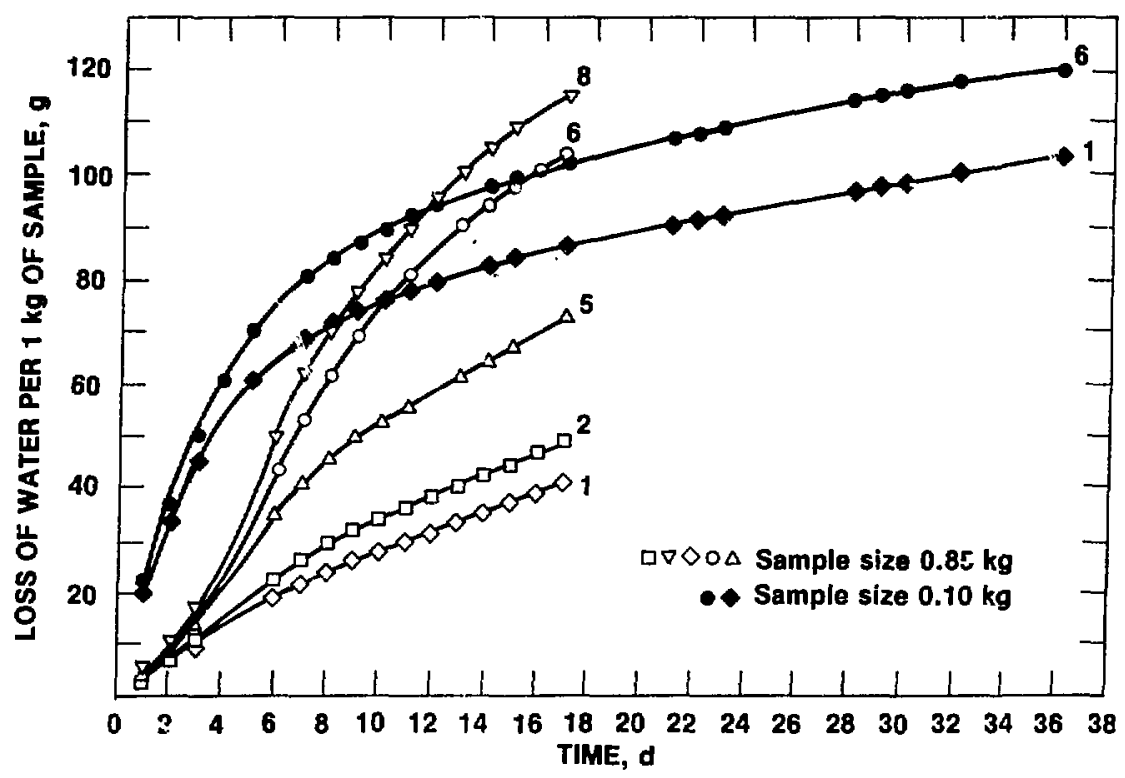

Fig. III-16. Water Loss vs. Time for Various Loadings of AgX in Concrete [BEONE]. (The sample numbers correspond to those in Table III-26.) 
Table III-26. Composition of Concrete Sampies Prepared from Pozzolanic Cement and AgX Zeolite [groNE]

\begin{tabular}{cccccc}
\hline Sample & $\begin{array}{c}\text { Weight } \\
\text { of Dry } \\
\text { No. }\end{array}$ & $\begin{array}{c}\text { Weight } \\
\text { of Dry } \\
\text { Cement, } 8\end{array}$ & \multicolumn{2}{c}{$\begin{array}{c}\text { Weight of Water } \\
\text { Zssociated, }\end{array}$} & $\begin{array}{c}\text { Zeolite } \\
\text { Content } \\
\text { in Cured } \\
\text { Concrete, } \\
\text { wt } \%\end{array}$ \\
\hline 1 & 900 & 150 & 450 & 45 & 10.1 \\
2 & 900 & 300 & 450 & 90 & 18.1 \\
3 & 1062 & 400 & 532 & 120 & 19.8 \\
4 & 699 & 450 & 350 & 135 & 30.0 \\
5 & 900 & 600 & 450 & 180 & 31.9 \\
6 & 900 & 815 & 450 & 245 & 37.7 \\
7 & 600 & 600 & 300 & 180 & 40.5 \\
8 & 900 & 1100 & 450 & 330 & 44.8 \\
9 & 450 & 750 & 225 & 225 & 49.5 \\
\hline
\end{tabular}

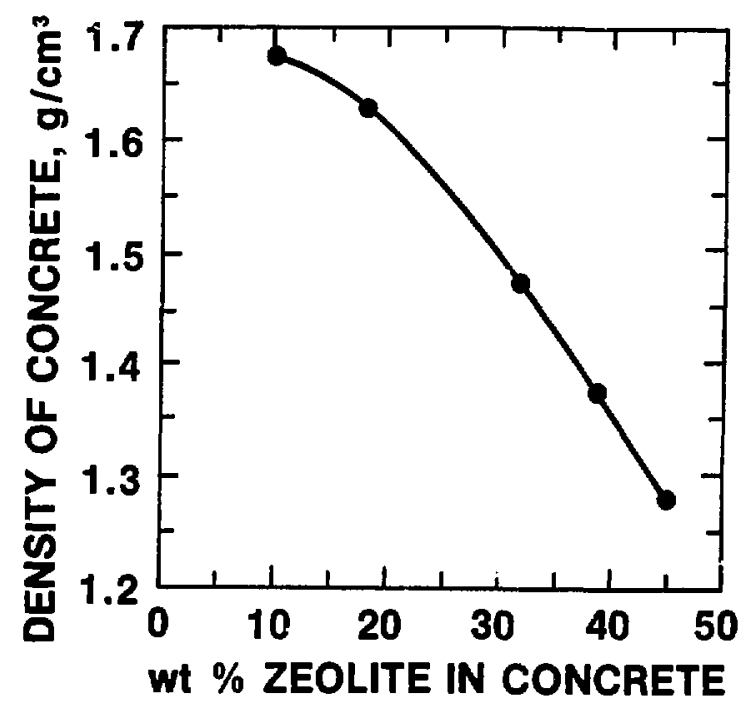

Fig. III-17. Density of Concret A Prepared from Pozzolanic Cement and Silver-Exchanged Zeolite of Different Compositions [BEONE]. 


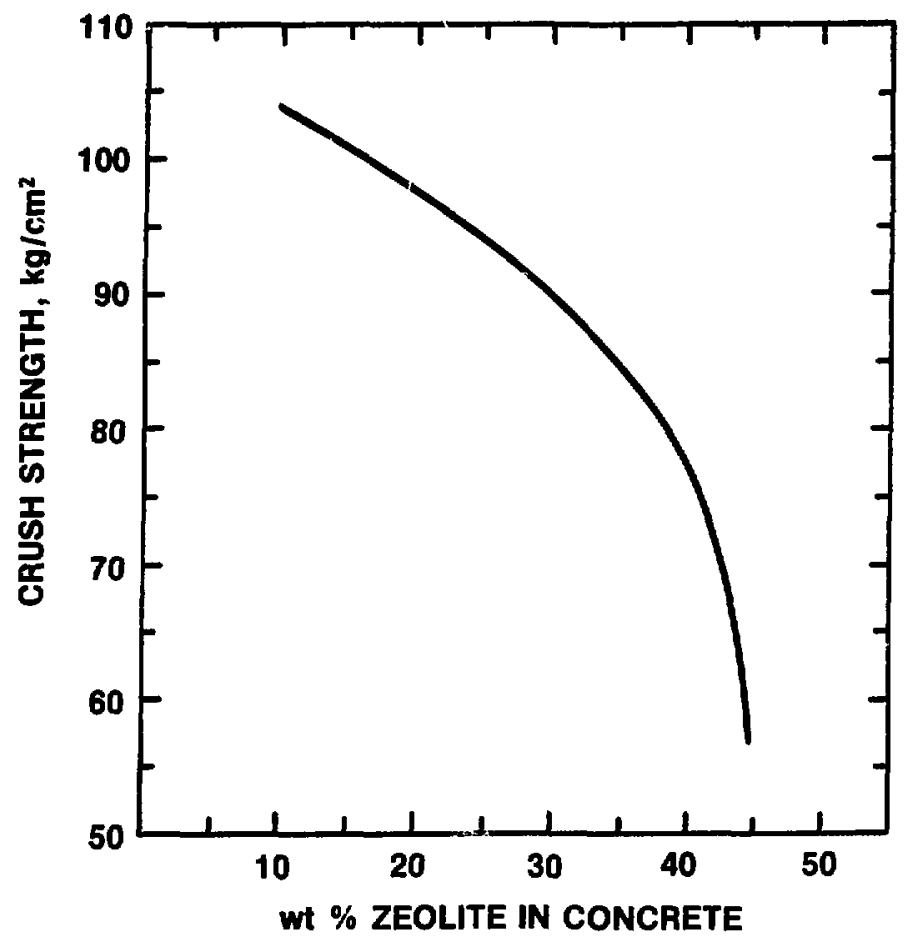

Fig. III-18. Crush Strength of Concrete Sample vs. the Zeolite Content [BEONE].

\section{c. Alternative Iodine Waste Forms}

Iodide sodalite has been the most studied alternative waste form for iodine and has been stated to be most promising [BURGER-1981A; CHIKALLA-1980, -1981B, -1981C; PLATT-1980 ; S'L'RACHAN; VANCE; WINTERS; BARNES]. The chemical formula of sodalite is $\mathrm{NagAl}_{6} \mathrm{SiO}_{24} \mathrm{X}_{2}$. The anions $\left(\mathrm{X}=\mathrm{Cl}^{-}, \mathrm{Br}^{-}\right.$, $\mathrm{I}^{-}$, $\mathrm{OH}^{-}$, etc.) reside in cages in the structure and are tetrahedrally coordinated to four $\mathrm{Na}^{+}$ions, thich, in turn, are incorporated in the aluminosilicate network. The theoretical maximum loading of iodide ion is 22 wt $\%$, and iodide sodalite has a theoretical maximum dengity of $2.6 \mathrm{~g} / \mathrm{cm}^{3}$.

Iodide sodalite has been prepared by mixing, in the proper proportions, solutions of either (1) $\mathrm{NaI}$ and $\mathrm{NaAlO} \mathrm{O}_{2}$ with an $\mathrm{SiO}_{2} \mathrm{sol}$ in aqueous ammonia or (2) $\mathrm{NaOH}, \mathrm{NaI}$, and kaol inite clay in an aqueous suspension. The gel product of this reactinn must then be dried, ground into a fine powder, and hot pressed at $a 1000^{\circ} \mathrm{O}$ and $34.5 \mathrm{MPa}(5000 \mathrm{psi})$ for $\mathrm{n} . \mathrm{h}$. Products of near theoretical density $\left(2.4 \mathrm{~g} / \mathrm{cm}^{3}\right)$ and iodide content $(\sim 19 w t z)$ have been prepared that show good thermal and radiation stability [BURGER-1981A, VANCE] .

The leach resistance of iodide sodalite was reportec to be 100 tiaes higher than that of $\mathrm{Ba}\left(\mathrm{IO}_{3}\right)_{2}$ in concrete and equivalent to that of AgI in concrete. Silver iodide was determined to be the most leach-resistant material encapoulated in concrete tested [BURGER-1981A]. 
There are two severe disadvantages to iodide sodalite production. The first is that sodium iodide is neither a conventional nor convenient product of any of the promising collection methods for volatile iodine. Some preliminary work has been done on mixing HI into a pot with excess $\mathrm{NaOH}$ to form NaI during sodalite production, but this process proved to be difficult to implement [CHIKALLA-1981C]; hydrogen iodide gas is the product of the regeneration of silver zeolite by hydrogen gas. Therefore, a great deal of initial research would be needed on the production of NaI from the collected radioiodine; this NaI production would later lead to a more complex operation for immobilization of radioiodine. Another disadvantage is the complexity of the iodide sodalite process itself when compared to the mixing of a solid with cement at ambient conditions. There are several steps to this process, one requiring high temperature and high pressure. This disadvantage is compounded because a loss of a few percent of iodine from the sodalite occurs during the hot-pressing step. The trapping and recycling of this iodine add even more complexity to the imobilization process.

\section{d. Sorption of Iodide and Iodate by Minerals and Soil Components}

Because the leach rates of I-129 from concrete are higher by several orfers of magnitude than its decay rate, the migration rate of I- 129 from the waste container to the environment is an important property of the disposal system. If geological burial is chosen for iodine, migration to an aquifer must be slow enough that dilution of I-129 in the groundwater makes it innocuous. If deep sea burial is the disposal option of choice, the migration rate must be low enough that isotopic dilution with natural iodine in the ocean makes I-129 innocuous. The requirement for isotopic dilution by seawater is a far less demanding criterion than that for dilution by groundwater. The following section is a literature survey of the retention properties of natural materials for iodine species, with emphasis on potential backfill-barrier materials that would inhibit the movement of iodine species from the waste canister.

In general, the anion-exchange capacity of minerals and soils is far less than their cation-exchange capacity. Table III-27 shows the anionexchange capacity of some common minerals [ALLARD-1980]; in that same table, for comparison, are the cation-exchange capacities of some of the minerals [GARRELS]. Anionic I-131 has been tested and used as a means to trace water flow through the ground [KAUFMAN, HAMID]. The major criterion for picking a tracer for these types of studies is the low sorption of the tracer by the solid matrix. It was determined that sorption of I-131 could be a prublem when used without a carrier, but that sorption could be eliminated as a problem if nonradioactive iodide was used with the tracer in the range of $10^{-4}$ to $10^{-3} \mathrm{M}$ as NaI.

A great deal of work has been done in studying what constituents of soil are responsible for its retention of iodine [BOYARINOVA-1973; DE; RAJA; REINIGER; SUGAWARA; WHITEHEAD-1973A, -1973B, -1974A, -1974B, -1978; WILDING?. These studies of soils throughout the world all came to the same general conclusion: there are three variables in soil. content that are primarily responsible for sorption of $\mathrm{I}^{-}$and $\mathrm{IO}_{3}--\mathrm{Al}_{2} \mathrm{O}_{3}, \mathrm{Fe}_{2} \mathrm{O}_{3}$, and organic matter. The importance of each constituent is primarily dependent on the pH of the groundwater 
Table III-27. Anion- and Cation-Exchange Capacities of Some Common Minerals [ALLARD-1980, GARRELS]

\begin{tabular}{|c|c|c|c|c|}
\hline & \multirow[b]{2}{*}{$\mathrm{Cl} \mathbf{a s}$} & \multirow[b]{2}{*}{ Mineral } & \multicolumn{2}{|c|}{$\begin{array}{c}\text { Exchange Capacities, } \\
\text { meq/kg }\end{array}$} \\
\hline & & & Anion ${ }^{2}$ & Cationb \\
\hline 1 . & Sulfide & $\begin{array}{l}\text { Chalcopyrite } \\
\text { Pyrite }\end{array}$ & $\begin{array}{r}0.5 \\
<0.3\end{array}$ & \\
\hline 2. & Oxides, hydroxides & $\begin{array}{l}\text { Magnetite } \\
\text { Limonite } \\
\text { Gibbsite } \\
\text { Hematite, corundum }\end{array}$ & $\begin{array}{r}0.4 \\
0.6 \\
0.5 \\
<0.3\end{array}$ & \\
\hline 3. & $\begin{array}{l}\text { Halides, } \\
\text { Carbonates, } \\
\text { Sulfates, } \\
\text { Phos phates }\end{array}$ & $\begin{array}{l}\text { Fluorite } \\
\text { Calcite, dolomite } \\
\text { Anhydrite } \\
\text { Apatite }\end{array}$ & $\begin{array}{l}0.2 \\
<0.3 \\
<0.1 \\
<0.1\end{array}$ & \\
\hline \multirow[t]{7}{*}{4.} & Silicates & & & \\
\hline & a. Nesosilicates & $\begin{array}{l}\text { Olivine } \\
\text { Zircon } \\
\text { Sphene } \\
\text { Garnet (almandine) }\end{array}$ & $\begin{array}{l}1.8 \\
0.7 \\
0.8 \\
0.4\end{array}$ & \\
\hline & b. Sorosilicates & Epidote & 0.5 & \\
\hline & c. Cyclosilicates & Beryl & 1.4 & \\
\hline & d. Inosilicates & $\begin{array}{l}\text { Augite, hornblende, } \\
\text { At tapulgite }\end{array}$ & $\begin{array}{r}<0.2 \\
0.7\end{array}$ & \\
\hline & e. Phyl losilicates & $\begin{array}{l}\text { Kaolinite } \\
\text { Serpentine } \\
\text { Montomorillonite } \\
\text { Halloysite } \\
\text { Muscovite } \\
\text { Biotite, chlorite }\end{array}$ & $\begin{array}{r}0.5 \\
6.9 \\
0.9 \\
1.5 \\
0.6 \\
<0.3\end{array}$ & $\begin{array}{c}30-150 \\
700-1000 \\
50-500\end{array}$ \\
\hline & f. Tectosilicates & $\begin{array}{l}\text { Anorthite } \\
\text { Microcline, albite, } \\
\text { bytownite, quartz }\end{array}$ & $\begin{array}{r}0.7 \\
<0.3\end{array}$ & \\
\hline
\end{tabular}

Anion exchange capacity for $\mathrm{Br}^{-}$at $\mathrm{pH}$.

${ }^{b}$ Cation exchange capacity at $\mathrm{pH} 7$. 
and on the contact time of the iodine-containing water and the soil. Figure III-19 shows a pH profile of the sorption of iodide by a typical British soil, $\mathrm{Al}_{2} \mathrm{O}_{3}, \mathrm{Fe}_{2} \mathrm{O}_{3}$, and organic matter. The general trend of the data aggests that sorption by organic matter is less pH-dependent than sorption by inorganic material. The soil exhibits a behavior expected from a weighted combination of all three of the soil constituents. Figure III-20 shows the capacity for sorption of $\mathrm{I}^{-}$by two soils under the same conditions and the rate for that sorption.

Iodates were determined by [WHITEHEAD-1974A] to be, in general, sorbed 1 ess by soils, $\mathrm{Fe}_{2} \mathrm{O}_{3}$, and $\mathrm{Al}_{2} \mathrm{O}_{3}$ than iodide or iodine was sorbed from $0.1 \mathrm{M}$ calcium chloride or $1.0 \mathrm{M}$ ammonium scetate solutions. The addition of composted crganic matter slowly decreased the solubility of $\mathrm{IO}_{3}^{-}$to that of $\mathrm{I}^{-}$ or $\mathrm{I}_{2}$; this, the author speculated, was due to the reduction of $\mathrm{IO}_{3}^{-}$by the organic matter to these species.

The differing sorption of iodine species was also witnessed by Wolfsberg [WOLFSBERG-1978] on studies of the sorption of iodine by Nevada Test Site aluvium from aluviun groundwater. The distribution ratio, $K_{d}$, for sorption from solution was measured to be $24.5 \mathrm{~mL} / \mathrm{g}$, while desorption produced a $K_{d}$ of 400-900 mu/g. He actributed this difference to there being more than one iodine species in the groundwater; the use of paper cliromatography showed the presence of three iodine species: $\mathrm{IO}_{4}-/ \mathrm{IO}_{3}{ }^{-} / \mathrm{I}^{-1}$ in the ratio of 10\%/40\%/50\%. This same author measured the sorption of iodine species by Nevada tuff minerals to be zero [WOLFSBERG-1980].

The high capacity for iodine retention of some organic matter has led researchers to test the use of charcoal and charcoal/clay mixes as backfill materials for disposal of I-129 [IKEDA, NOWAK]. The distribution ratios of iodide between a brine solution and three types of activated charcoals are listed in Table III-28. Based on the data of Table III-28 and assuming a backfill of three feet around the waste container, Nowak has calculated that a backfill of $30 \%$ bentonite and $70 \%$ activated charcoal (bulk density $=n 2 \mathrm{~g} / \mathrm{cm}^{3}$ and effective porosity $=$ w.1) would have a time before "breakthrough" of $1000 \mathrm{y}$. "Breakthrough" is defined by the author as being the point when the concentration of $\mathrm{I}^{-}$leaving the backfill barrier is 17 of that entering it from the waste form. Bentonite has no 8 ignificant retention capacity for iodide. The mixture suggested by Nowak was made to sorb cationic species as well as anionic iodine and technetium species, based on the questionable assumption that all fission products would be disposed of together.

Ikeda and Tamaka [IKEDA] measured the distribution of iodide and iodate between aqueous phases of various $\mathrm{pH}$ values ana activated charcoal. Both $\mathrm{I}^{-}$and $\mathrm{IO}_{3}^{-}$sorb on charcoal at $\mathrm{pH}$ values lower than 10 for iodide and 9 for iodate. Distribution ratios for this system are presented in Table III-29. The author speculated that the iodate distribution becomes much like that of iodide at low pH values because iodate is being reduced to form iodide in this pH region. 


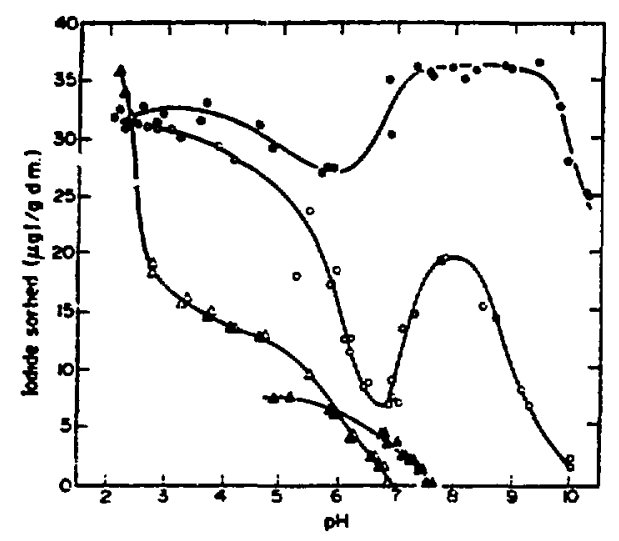

Fig. III-19

The Effect of pH on the Sorption of Iodide by Soil (0), Root Compost (0), Ferric Oxide $(\Delta)$, and Aluminum Oxide (A) from Solutions Containing Initially $40 \mathrm{\mu g}$ I/100 mL [WHITEHEAD-1974B]

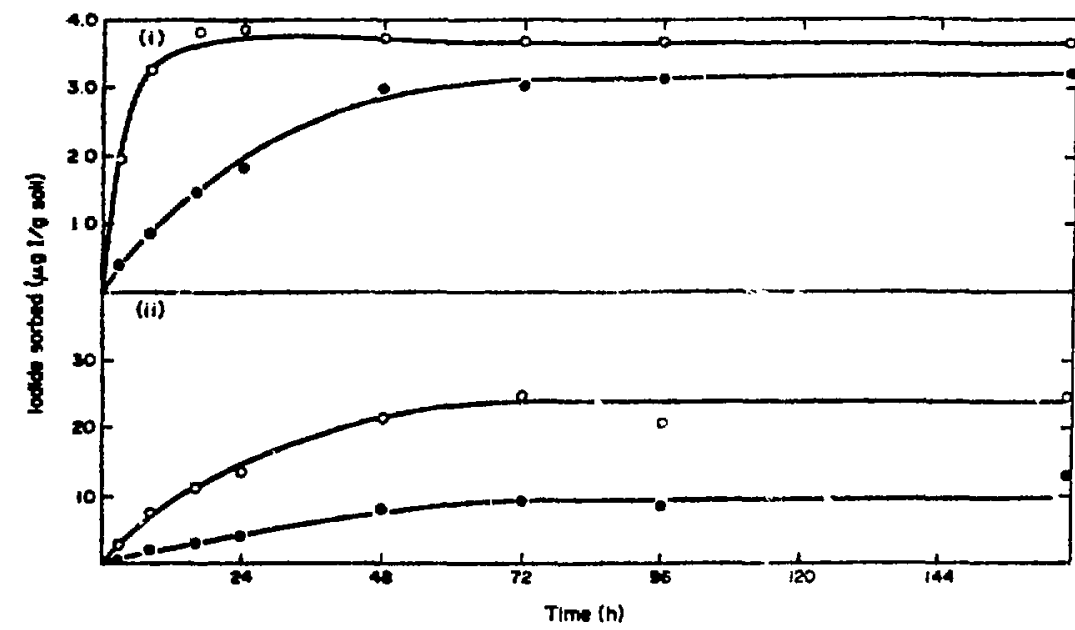

Fig. III-20. The Effect of Time on the Sorption of Iodide by

Two Soils from Initial Iodide Concentrationa of

(i) $40 \mu \mathrm{g} / / 100 \mathrm{~mL}$ and (ii) $400 \mu \mathrm{g} \mathrm{I} / 100 \mathrm{~mL}$ :

(o) soil 1A; (o) soil 2A; pH * 5.5 [HHITEHEAD1973A] 
Table III-28. Distribution Ratio of Iodide between Activated Charcoal and Brinea [NOWAK]

\begin{tabular}{|c|c|c|}
\hline Solid Sorbent & $\mathrm{K}_{\mathrm{d}}, \mathrm{mL} / \mathrm{g}$ & $\mathrm{pH}$ \\
\hline Activated "Nuchar" & 35 & 6.6 \\
\hline Activated Coconut Charcoal & 53 & 6.7 \\
\hline Activated "Darco" G-60 & 18 & 6.5 \\
\hline
\end{tabular}

Table III-29. Distribution of Iodide and Iodate between Water of Differing pH Values and Activited Charcoal [IKEDA]

\begin{tabular}{ccc}
\hline Lodine Species & $\mathrm{pH}$ & Distribution Ratio, $\mathrm{mL} / \mathrm{g}$ \\
\hline $\mathrm{I}^{-}$ & 8.5 & $10^{2}$ \\
& 5 & $10^{3}$ \\
$\mathrm{IO}_{3}{ }^{-}$ & 3.5 & $10^{4}$ \\
& 9 & 0.6 \\
& 6 & 10 \\
& 4 & $10^{2}$ \\
& 3 & $10^{3}$ \\
\hline
\end{tabular}

In addition to charcoal, several minerals are possible sorbents for iodide and iodate [ALLARD; BIRD; BOYARINOVA-1972; COUTURE; HAQ; NEAL; STE INDLER-1978, -1979A, -1979B, -1979C; STRICKERT-1978, -1980]. The mechanism for these sorbents is not ion exchange but rather chemical reaction. In general, minerals that sorb iodine species are oxides and sulfides of heavy metals that have low solubilities of iodide and iodate salts.

Allard et al. [ALLARD-1980] tested several minerals of this type. In general, in the pli range studied (3-11), sorption of iodide was highest at low $\mathrm{pH}$ values and decreased at higher $\mathrm{pH}$ values; the exception was lead hydroxide, which showed increased sorption with pH. Bird and Lapata [BZRD] found PbO and Cu metal to be excellent sorbents for iodide. Lead oxide sorbed $\mathrm{I}^{-}$ion at greater than $95 \%$ efficiency from mole ratios of $4.5 \times 10^{-10}$ to $0.2 \mathrm{I} / \mathrm{PbO}$; at mole ratios between 0.2 and 3 , the percent of $\mathrm{I}$ sorbed dropped draratically. As $\mathrm{I}^{-}$was removed from solution, the $\mathrm{pH}$ of the solution increased. The observed increase in $\mathrm{pH}$ is explainable by the following reuctions: 


$$
\begin{gathered}
x P B O+y_{2} \mathrm{O}+2 \mathrm{yI}^{-} \rightleftharpoons(x-y) \mathrm{PbO}^{-} \mathrm{yPbI}_{2}+2 \mathrm{yOH} \\
(x+y) \mathrm{PbO}+2 \mathrm{xI}^{-}+(x+y) \mathrm{H}_{2} \mathrm{O} \rightleftharpoons \mathrm{xPbI}_{2} \cdot \mathrm{yPb}(\mathrm{OH})_{2}+2 \mathrm{xOH}^{-}
\end{gathered}
$$

$X$-ray diffraction confimed that $\mathrm{PbIOH}$ exists on the surface of the solid when $\mathrm{I}^{-} / \mathrm{PbO}$ mole ratio $=3$. At lower ratios, $\mathrm{Pb}(\mathrm{OH}) \mathrm{I}$ was not found; instead, other unidentified species of variable composition were seen.

Haq et al. [HAQ] measured the kinetics and thermodynamics of the sorption of iodide by copper metal, $\mathrm{Cu}_{2} \mathrm{O}$ and $\mathrm{CuO}$. Both copper metal and cuprous oxide sorb $\mathrm{I}^{-}$rapidly from solution of $\geq 10^{-6} \mathrm{M} \mathrm{I}^{-}$(50 $\mathrm{mL}$ of solution to 58 of solid sorbent). The mechanism of sorption for both $\mathrm{Cu}$ metal and $\mathrm{Cu}_{2} \mathrm{O}$ is the formation of $\mathrm{Cu}^{+}\left(\mathrm{I}^{-}\right)\left(\mathrm{OH}^{-}\right)$, followed by crystallization of CuI and loss of hydroxide to the solution. Thus, the amount of iodide removed from solution is controlled by the solubility product of cuprous iodide $\left(K_{8 p}=1.1 \times 10^{-12}\right)$. There is no significant sorption of iodide by CuO. Based on the results of this study, the authors recomend that the waste containers for disposal of 129 I be fabricated from copper; if the container is breached, the container material will still continue to limit the migration of iodine species into the environment.

Boyarinova et al. [BOYARINOVA-1972] have studied the coprecipitation of iodate ion with hydroxides. They have found that coprecipitation decreases the iodate concentration more substantially than sorption on previously precipitated hydroxides. The order of effectiveness of the removal of iodate from solution by the hydroxides studied was: $\mathrm{Mn}^{4+}<\mathrm{Sn}^{4+}<\mathrm{Fe}^{3+}<$ $\mathrm{Al}^{3+}<\mathrm{Sn}^{2+}<\mathrm{Ni}^{2+}$. For example, at $\mathrm{pH}=8.5,96 \%$ of the $\mathrm{IO}_{3}{ }^{-}$present in soluticn coprecipitated with $\mathrm{Ni}(\mathrm{OH})_{2}$; at this same $\mathrm{pH}, 75 \%$ coprecipitated with $\mathrm{Sn}(\mathrm{OH})_{2}$ - Coprecipitation only occurred below this pH for tetravalent cations.

Work performed by Couture and Seitz [COUTURE; STEINDLER-1978, $-1979 \mathrm{~A},-1979 \mathrm{~B},-1979 \mathrm{C}$ ] showed that hematite $\left(\mathrm{Fe}_{2} \mathrm{O}_{3}\right)$ was an effective sorbent for $\mathrm{IO}_{4}^{-}, \mathrm{IO}_{3}^{-}$, and $\mathrm{I}^{-}$; the effectiveness of sorption is in the order given. At any given $\mathrm{pH}$, the sorption of periodate was determined to be $w_{4}$ times higher than that of iodate, and iodide retention was orders of magnitude lower. The data presented in Fig. III-21 show (1) the inverse relationship between soiution $\mathrm{pH}$ and the degree of sorption of iodate on hematite and (2) the linear logarithmic relationship between the amount: of iodate sorbed on the hematite and the aqueous phase concentration of iodate for a concentration range of almost eight orders of magnitude. The linear logarithmic relationship begins to level off when the surface concentration of iodate approaches a saturation value $\left(10^{-4} \mathrm{~mol}^{-1 O_{3}}-/ 8 \quad \mathrm{Fe}_{2} \mathrm{O}_{3}\right)$. The sorption of iodate on hematite was found to be reveraible by approaching the equilibrium condition from both high and low pH. This was accomplished by allowing the system to equilibrate at one $\mathrm{pH}$ before the $\mathrm{pH}$ was lowered by the consecutive additions of acids. These measurenents were repeated by raising the pH again by consecutive additions of base. This experiment is depicted graphically in Fig. III-22.

These researchers also examined the sorption characteristics of two Pacific pelagic red cluye that each contained 25 wt $7 \mathrm{Fe}_{2} \mathrm{O}_{3}$. On the basis of their $\mathrm{Fe}_{2} \mathrm{O}_{3}$ content and the sorption behavior of henatite, these clays were 
Fig. III-21.

Sorption of Iodate by Hematite $\left(\mathrm{Fe}_{2} \mathrm{O}_{3}\right)$. ( $\mathrm{r}$ is amount sorbed, nol/s $\mathrm{Fe}_{2} \mathrm{O}_{3}$. $\left[\mathrm{IO}_{3}{ }^{-}\right]$is in units of molarity. Squares indicate titrations, and circles indicate radiometric measurement. [STEINDLER-1979B].)
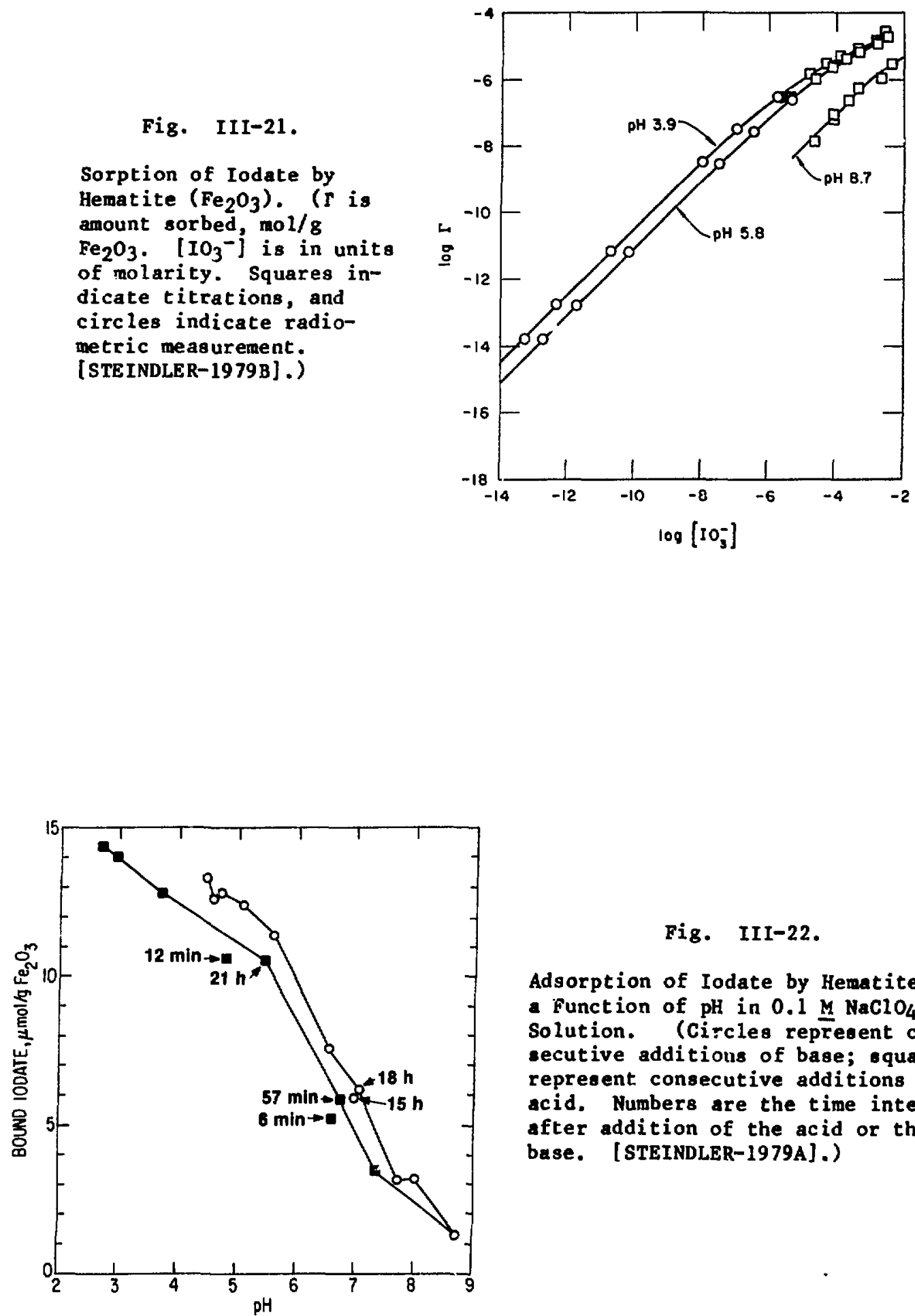

Fig. III-22.

Adsorption of Iodate by Hematite as a Function of pH in $0.1 \mathrm{MaClO} \mathrm{Na}_{4}$ Solution. (Circles represent consecutive additions of base; squares represent consecutive additions of acid. Numbers are the time intervals after addition of the acid or the base. [STEINDLER-1979A] .) 
expected to sorb only about one half of the amount of iodate they actually did. This higher retention of iodate was attributed to the probable smaller particle size of $\mathrm{Fe}_{2} \mathrm{O}_{3}$ in the clays, hence, higher surface area-to-weight ratio of the sorbing species.

Neal and Truesdale [NEAL] studied the sorption of iodide and iodate from fresh and salt water by ferric hydroxide, peat, and kaolinite. Ferric hydroxide was determined to be the best of the three for sorbing iodide from salt water, followed by peat and then kaolinite. Peat differed from ferric hydroxide and kaolinite in that the amount of sorption did not vary between fresh and salt waters.

Strickert et al. [STICKERT-1978, -1980] studied the sorption of $\mathrm{I}^{-}$and $\mathrm{IO}_{3}{ }^{-}$by a long list of minerals and laboratory-grade chemicals. Some of their results are presented in Tables III-30 and III-31. The aqueous phases in these experiments were pre-equilibrated in most cases with the minerals studied. In a few experiments, solutions other than pre-equilibrated aqueous phases were tested. This procedure made little impact on sorption except when simulated WIPP brine was ved; as can be seen from the data in Table III-32, the saturated NaCl solution did significantly lower the sorption of $\mathrm{IO}_{3}{ }^{-}$on all the minerals tested.

Figure III-23 shows that sorption of iodide ion by sulfide minerals, as for soils, is not an instantaneous process. The difference between soil and cuprous sulfide is the much higher retention of iodide by $\mathrm{Cu}_{2} \mathrm{~S}$. These authors found, as did others, that a mineral's anion-exchange capacity is not the important criterion for effective sorption of $\mathrm{I}^{-}$and $\mathrm{IO}_{3}^{-}$; rather, this capacity was due to coprecipitation or to incorporation of iodide or iodate into the mineral lattice.

above are:

The conclusions to be drawn from the literature survey presented

- I-129 will migrate freely in most soils and groundwater once it is leached from the waste form unless special precautions are taken.

- Because the ion-exchange capacity of most materials is very poor, conventional backfill materials such as clay minerals are nearly useless.

- Effective backfill materials for secention of I-129 species can be of two types: (1) organic materials such as activated charcoal or composted organic matter and (2) heavy metals and heavy metal oxides and sulfides that sorb iodide by chemical reaction. The effectiveness of the second type of materials is primarily based on the low solubility products of their iodide and iodate salts.

\section{e. Burial Options for I-129}

Some authors [ALTOMARE] do not favor a geological repository because the extremely long half-1ife of decay for I-129 makes it impossible to predict that the disposal site will remain water free for even a small fraction of the time needed for extensive decay of I-129. This fact, the relatively high predicted leach rates of iodine from concrete, and the low retention of iodine species in most minerals and soils (see above) makes the certainty of 
Table III-30. Distribution Ratio $\left(K_{d}\right)$ Values for Various Rocks and Minerals

\begin{tabular}{|c|c|c|c|}
\hline \multirow[b]{2}{*}{ Material } & \multirow[b]{2}{*}{ Major Constituents } & \multicolumn{2}{|c|}{$\mathrm{K}_{\mathrm{d}}, \mathrm{ml} / \mathrm{s}$} \\
\hline & & $I^{-}$ & $\mathrm{IO}_{3}^{-}$ \\
\hline $\begin{array}{l}\text { Apatite } \\
\text { Anhydrite } \\
\text { Witherite } \\
\text { Columbia river } \\
\text { basalt }\end{array}$ & $\begin{array}{l}\mathrm{Ca}_{5}(\mathrm{Cl}, \mathrm{F})\left(\mathrm{PO}_{4}\right)_{3} \\
\mathrm{CaSO}_{4} \cdot 2 \mathrm{H}_{2} \mathrm{O} \\
\mathrm{BaCO}_{3} \\
\text { Feldspar, diopside }\end{array}$ & $\begin{array}{l}<1 \\
-\end{array}$ & $\begin{array}{l}- \\
4 \\
1\end{array}$ \\
\hline $\begin{array}{l}\text { PNL basalt } \\
\text { Chalk } \\
\text { NTS dolomite } \\
\text { Granite }\end{array}$ & $\begin{array}{l}\text { Feldspar, diopside } \\
\mathrm{CaCO}_{3}, \text { clay } \\
\mathrm{CaMg}\left(\mathrm{CO}_{3}\right)_{2}, \mathrm{SiO}_{2} \\
\text { Feldspar, } \mathrm{KAlSi} \mathrm{S}_{3}\end{array}$ & $\begin{array}{l}- \\
<1 \\
<1 \\
<1\end{array}$ & $\begin{array}{r}<1 \\
5 \\
<1 \\
<1\end{array}$ \\
\hline $\begin{array}{l}\text { PNL granite } \\
\text { Low temperature } \\
\text { metamorphic } \\
\text { Pierre shale } \\
\text { PNL shale }\end{array}$ & $\begin{array}{l}\text { Feldspar, } \mathrm{SiO}_{2} \\
\text { Chlorite, felds par } \\
\mathrm{SiO}_{2} \text {, feldspar } \\
\mathrm{SiO}_{2} \text {, feldspar }\end{array}$ & <i & $\begin{array}{l}3 \\
1 \\
9\end{array}$ \\
\hline $\begin{array}{l}\text { Mottled siltstone } \\
\text { LASL cuff } \\
\text { NTS tuff } \\
\text { PNL limestone }\end{array}$ & $\begin{array}{l}\text { Montmorillonite } \\
\mathrm{SiO}_{2} \\
\mathrm{SiO}_{2} \\
\mathrm{CaCO}_{3}, \mathrm{SiO}_{2}\end{array}$ & $\begin{array}{l}<1 \\
<1 \\
<1 \\
-\end{array}$ & $\begin{array}{r}5 \\
<1 \\
<1 \\
16\end{array}$ \\
\hline $\begin{array}{l}\text { Bornite } \\
\text { (with molybdenite) } \\
\text { Bournonite } \\
\text { Chalcopyrite } \\
\text { Chrysocolla }\end{array}$ & $\begin{array}{l}\mathrm{Cu}_{5} \mathrm{FeS}_{4} \\
\left(\mathrm{MoS}_{2}\right) \\
\mathrm{CuPbSbS}_{3} \\
\mathrm{CuFeS}_{2} \\
\mathrm{CuSiO}_{3} \cdot 2 \mathrm{H}_{2} \mathrm{O}\end{array}$ & $\begin{array}{l}30-790 \\
200-1000 \\
190 \\
3-12\end{array}$ & $\begin{array}{c}10,1000 \\
960 \\
400-1300 \\
40-75\end{array}$ \\
\hline $\begin{array}{l}\text { Enargite } \\
\text { Galena } \\
\text { Pyrite } \\
\text { Tennantite }\end{array}$ & $\begin{array}{l}\mathrm{Cu}_{3 \mathrm{AsS}_{4}} \\
\mathrm{PbS} \\
\mathrm{FeS}_{2} \\
(\mathrm{Cu}, \mathrm{Fe})_{12} \mathrm{As}_{4} \mathrm{~S}_{13}\end{array}$ & $\begin{array}{c}130,150 \\
26 \\
300-3000 \\
100-350\end{array}$ & $\begin{array}{l}70,120 \\
3,30,45 \\
>1000 \\
10-20\end{array}$ \\
\hline $\begin{array}{l}\text { Tetrahedrite } \\
\text { Tetrahedrite } \\
\text { (argent iferous) }\end{array}$ & $\begin{array}{l}(\mathrm{Cu}, \mathrm{Fe})_{12} \mathrm{As}_{4} \mathrm{~S}_{13} \\
(\mathrm{Cu}, \mathrm{Ag}, \mathrm{Fe})_{12} \mathrm{Sb}_{4} \mathrm{~s}_{13}\end{array}$ & $\begin{array}{c}1100,1500 \\
t-20,150-680\end{array}$ & $\begin{array}{c}1000-3000 \\
32\end{array}$ \\
\hline \multicolumn{4}{|c|}{$\begin{array}{l}\text { The distribution ratio, } K_{d} \text {, is defined by the following equation } \\
\qquad K_{d}=\frac{F_{R}}{1-F_{R}} \cdot \frac{V_{T}}{M_{R}} \\
\text { where } V_{T} \text { is the total volume of the solution in ml, and } M_{R} \text { is msss of } \\
\text { the rock in } g \text {; } F_{R} \text {, the fraction of activity sorbed by the rock, is } \\
\text { defined by the relationship: }\end{array}$} \\
\hline \multicolumn{4}{|c|}{$\begin{array}{l}A_{a} \text { and } V_{a} \text { are the activity and the volume of the aliquot removed from } \\
\text { the solution, and } A_{T} \text { is the total activity put into the solution. } \\
\text { For the conditions used in these experiments, a } K_{d} \text { of } v 1 \text { indicates that } \\
25 \% \text { was sorbed from the solution: a } K_{d} \text { of } 10 \text { indicate } w 50 \% \text { and a } K_{d} \\
\text { of } 100 \text { indicates that } 79 \% \text { of the tracer was sorbed from the solution. }\end{array}$} \\
\hline
\end{tabular}


Table III-31. Fraction of Radiotracers Sorbed on Various Chemical Reagents

\begin{tabular}{|c|c|c|}
\hline \multirow[b]{2}{*}{ Chemical } & \multicolumn{2}{|c|}{$F_{R} a^{a}$} \\
\hline & $\mathrm{I}^{-}$ & $\mathrm{IO}_{3}^{-}$ \\
\hline CdS & 0.97 & - \\
\hline $\begin{array}{l}\mathrm{Cu}_{2} \mathrm{~S} \\
\mathrm{CuS}\end{array}$ & $\begin{array}{l}0.99+ \\
0.99+\end{array}$ & $\begin{array}{l}0.99+ \\
0.99+\end{array}$ \\
\hline Fes & - & 0.14 \\
\hline $\mathrm{HgS}$ & 0.70 & - \\
\hline Pbs & $0.94 \pm 0.05$ & $0.95 \pm 0.04$ \\
\hline ZnS & 0.10 & - \\
\hline CuCl & 0.56 & 0.59 \\
\hline $\mathrm{CuCO}_{3} \cdot \mathrm{Cu}(\mathrm{OH})_{2} \mathrm{~b}$ & 0.56 & 0.59 \\
\hline CuO & 0.07 & $0.7 \pm 0.2$ \\
\hline $\mathrm{Fe}$ & $0.01,0.4$ & 0.09 \\
\hline $\mathrm{FeCl}_{2} \cdot 4 \mathrm{H}_{2} \mathrm{O}$ & 0.18 & - \\
\hline $\mathrm{Fe}_{2} \mathrm{O}_{3}$ & 0.61 & - \\
\hline $\mathrm{FeSO}_{4}$ & 0.09 & - \\
\hline $\mathrm{Pb}$ & 0.97 & - \\
\hline $\mathrm{PbO}_{2}$ & 0.01 & - \\
\hline Ag powder & $0.99+$ & - \\
\hline
\end{tabular}

asee foot note on Table III-30.

$b_{\text {For runs of shorter duration (few hours), greater }}$ sorption for iodide $(0.97)$ was observed.

Table III-32. Sorption of Iodate by Several Materials from Groundwater and Simulated WIPP Brine

\begin{tabular}{llcr}
\hline Material & $\begin{array}{c}\text { Equilibrated } \\
\text { Solution }\end{array}$ & $\begin{array}{c}\text { Rock } \\
\text { Mass, },\end{array}$ & $\begin{array}{c}\mathrm{F}_{\mathrm{R}} \mathrm{I}^{\mathrm{a}} \\
\mathrm{OO}_{3}\end{array}$ \\
\hline Bornite & Groundwater & 0.717 & 0.98 \\
WIPP solution & 0.712 & 0.53 \\
& Groundwater & 0.370 & 0.97 \\
& WIPP solution & 0.454 & 0.28 \\
Enargite & Groundwater & 0.522 & 0.99 \\
& WIPP solution & 0.647 & 0.41 \\
Galena & Groundwater & 0.873 & 0.97 \\
& WIPP solution & 1.283 & 0.79 \\
Tetrahedrite & Groundwater & 0.813 & 0.50 \\
& WIPP solution & 0.819 & 0.04 \\
& Groundwater & 1.062 & $>0.99$ \\
& WIPP solution & 1.268 & 0.82 \\
\hline
\end{tabular}

asee footnote on Table III-30. 


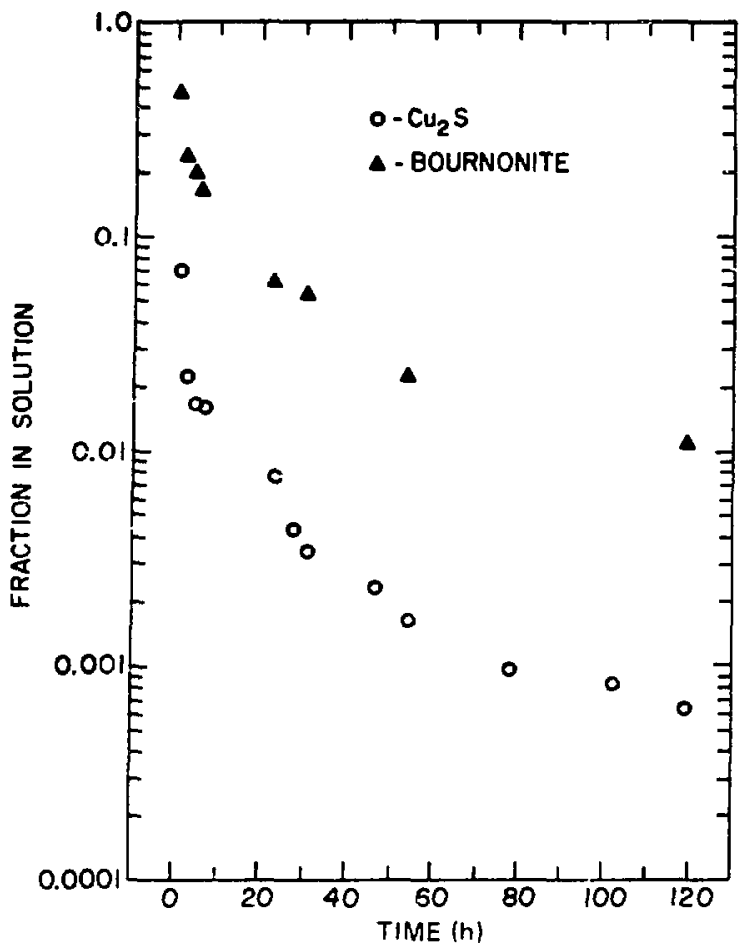

Fig. III-23. Sorption of Iodide Tracer Activity on $\mathrm{C}^{\prime \prime}{ }_{2} \mathrm{~S}$ and Bournonite as a Function of Time [STRICKERT-1980].

isolating I-129 frow the natural environment very low. The impact of I-129 entering the biosphere is, of course, dependent on the rate of its release. If the rate of release can be assured to be low enough that equilibration with a large body of water is assured, the impact will be small.

Wood and Richardson have done a calculation for deep geologic disposal, based on ( 1 ) a "typical" concrete waste-form cylinder ( $3 \mathrm{~m}$ long by $0.3 \mathrm{~m}$ in diameter) containing $6 \mathrm{wt} \% \mathrm{I}-129$ and (2) the oRNL leaching rate [WOOD]. If the total radioiodine waste for $20 \mathrm{y}$ of operation from a 1500 MTHM/y reprocessing plant $(600 \mathrm{~kg}$ of iodine/y) were buried in a repository in such concrete cylinders, the amount of iodine leached the first year would be $4.9 \times 10^{5} \mathrm{~g}(88 \mathrm{Ci})$. If this raterial finds its way into an aquifer with a typical flow rate of $200 \mathrm{cfs}$ (or $16 \times 10^{13} \mathrm{cc} / \mathrm{y}$ ), the concentration of I-129 would be $5 \times 10^{-7} \mathrm{inCi} / \mathrm{L}$. This concentration is somewhat greater than the maximum permissible concentration (MPC) of soluble I-129 set by 10 CFR 20 of $6 \times 10^{-8} \mathrm{mCi} / \mathrm{L}[\mathrm{BROWN}-1980]$.

Seabed disposal is an attractive alternative to continental disposal, primarily because of the effect of isotope dilution of I-129 with natural iodine I-127 in sea water [MORGAN, BURGER-1980]. The concentration of natural iodine in the ocean, $4.9 \times 10^{-5} \mathrm{~g} / \mathrm{L}$, is 145 times greater than 
the MPC of I-129 $\left(6 \times 10^{-8} \mathrm{mCi} / \mathrm{L}=3.4 \times 10^{-7} \mathrm{~g} / \mathrm{L}\right)$ and, therefore, would reduce the specific activity of I-129 even at a concentration as large as the MPC by a factor of 145. The importance of lowering the specific activity of I-129 can be seen by looking at the distribution of iodine in the body and the maximum permissible body burden of I-129. The major collection point of iodine in the body is the thyroid gland, which contains $27 \mathrm{mg}$ of iodine. The maximum permissible burden of $\mathrm{I}-129$ is $0.6 \mu \mathrm{Ci}$ or $3.4 \mathrm{mg}$ of iodine. Thus, for a person to receive a maximum perinissible burden of I-129, approximately $50 \%$ of the iodine content in his body, which for all practical purposes is $50 \%$ of his thyroid iodine content, would need to be I-129. Diluting I-129 with natural iodine, even as little as by a factor of two, makes it impossible to exceed the maximum permissible burden. Dilution by a factor of 145 would make the maximum possible burden only $1.4 \%$ of the maximum permissible burden. lsotopic dilution of al.1 the I-129 collected from nuclear fuel reprocessing through the year 2020 by all the natural iodiae in the oceans (dilution by seven to eight orders of magnitude) would make the specific activity of iodine so low as to be inconsequential.

To as sure mixing of I-129 with natural iodine, low leaching rates of iodine into the sea must be assured. The principal barriers to transport of iodine from the waste form would be about the same as with dry land hurial [WOOD]:

(1.) the waste matrix,

(2) the container,

(3) the geological isolation (basement rock or sediment),

(4) soil adsorption.

Because of the possibility of isotopic dilution by natural iodine in sea water, however, the criteria for leaching retardation ..re not as stringent.

E. Technologies of Carbon Waste Forms

1. Decay Characteristics of C-14-Containing Material

Carbon- 14 has a half-life of $5730 \pm 40 \mathrm{y}$ by $\mathrm{B}^{-}$decay. The maximum

$B^{-}$decay energy is $156.08 \pm 0.24 \mathrm{keV}$; the average $B^{-}$decay energy is $49.30 \pm 0.10 \mathrm{keV}$ [MARTIN]. Table III-33 shows the specific activities and thermal outputs of various chemical forms of $\mathrm{C}-14$. As shown, the thermal output of $\mathrm{C}-14$ is $13 \times 10^{4} \mathrm{~W} / \mathrm{g}\left(2.91 \times 10^{-4} \mathrm{~W} / \mathrm{Ci}\right)$.

Because the collection systam for ${ }^{14} \mathrm{CO}_{2}$ in the LWR-reprocessing plant also collects natural $\mathrm{CO}_{2}$ in the plant atmosphere, there will be a great deal more natural, unradioactive $\mathrm{CO}_{2}$ than radioactive ${ }^{14} \mathrm{CO}_{2}$ collected. The ratio of ${ }^{12} \mathrm{CO}_{2} /{ }^{14} \mathrm{CO}_{2}$ coilected was estimated by [ALTOMARE] to be in the range of 10 to 100. Brown et al. [BROWN-1980] estimated that a caustic scrubber would produce $1.6 \mathrm{MT}$ of total calcium carbonate to trap the $1.8 \mathrm{~kg}$ of $\mathrm{Ca}^{14} \mathrm{CO}_{3}$ produced in a typical reprocessing plant (C-12/C-14, 2900). Once the slurry from the scrubber is mixed with cement and formed into concrete, the initial $200 \mathrm{~g}$ of C-14 is diluted to $65 \mathrm{MT}$ of concrete, a dilution factor of $\mathbf{3 2}, 000$ times. The specific activity of the final waste form would be $n 13 \mathrm{Ci} / \mathrm{MT}$ or $22 \mathrm{ci} / \mathrm{m}^{3}$. 
Table III-33. Specific Activities and Thermal Ouiputs of ${ }^{14} \mathrm{C}$ Chemical species

\begin{tabular}{|c|c|c|c|c|c|c|c|c|c|}
\hline \multirow[b]{2}{*}{$\begin{array}{l}\text { Chemical } \\
\text { Species }\end{array}$} & \multirow[b]{2}{*}{ wt? } & \multirow[b]{2}{*}{$\% \mathrm{c}-14$} & \multirow[b]{2}{*}{$\begin{array}{l}\text { Density, } \\
\text { g/ } / \mathrm{cm}^{3}\end{array}$} & \multicolumn{2}{|c|}{ Specific Activity } & \multicolumn{2}{|c|}{ Thermal Output ${ }^{a}$} & \multicolumn{2}{|c|}{$\begin{array}{l}\text { Amount to } \\
\text { Contain } 850 \mathrm{Ci}\end{array}$} \\
\hline & & & & $\mathrm{Ci} / \mathrm{g}$ & $\mathrm{Ci} / \mathrm{cm}^{3}$ & $\begin{array}{r}W / g \\
\times 10^{4}\end{array}$ & $\begin{array}{l}W / \mathrm{cm}^{3} \\
\times 10^{4}\end{array}$ & $\mathrm{~kg}$ & $\mathrm{dm}^{3}$ \\
\hline$c-14$ & & 100 & -- & 4.46 & -- & 13.0 & - & 0.191 & -- \\
\hline $\mathrm{Ca}^{14} \mathrm{CO}_{3}$ & & 14 & $2.74^{b}$ & 0.624 & 1.72 & 1.82 & 4.99 & 1.82 & 0.494 \\
\hline $\mathrm{Ba}^{14} \mathrm{CO}_{3}$ & & 7.0 & $4.33^{c}$ & 0.312 & 1.35 & 0.91 & 3,94 & 2.72 & 0.644 \\
\hline${ }^{14} \mathrm{CO}_{2}$ & & 30.4 & -- & 1.36 & - & 3.96 & -- & 0.62 & - \\
\hline
\end{tabular}

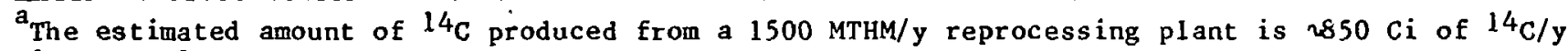
[ALTOMARE].

${ }^{b}$ Based on the density of the more stable form, calcite ( $\left.d=2.711 \mathrm{~g} / \mathrm{cm}^{3}\right)$ [DEAN], and the higher molecular weight of $\mathrm{Ca}^{14} \mathrm{CO}_{3}$. (The less stable form, aragonite, has a density of $2.93 \mathrm{~g} / \mathrm{cm}^{3}$.)

${ }^{c}$ Based on the density of witherite $\left(\mathrm{d}=4.29 \mathrm{~g} / \mathrm{cm}^{3}\right)$ [DEAN] and the higher molecular weight of $\mathrm{Ba} 14 \mathrm{CO}_{3}$. 


\section{Collection of Carbon}

A cricical review of collection sethods has been presented by Brown et a1. [BROWN-1931]. These methods are also discussed by Altomare et al. [ALTOMARE]. They will be briefly discussed below, with an emphasis on the amount and form of the collection product. Other references pertinent to each collection method are listed after the subsection headings below.

$$
\text { a. Caustic Scrubbing [CROFF-1976; BRAUN-1980, -1983; }
$$

Absorption of $\mathrm{CO}_{2}$ by a sodium hydroxide solution in a packed scrubbing column is a common industrial process. Although this process is untested as a means to trap ${ }^{14} \mathrm{CO}_{2}$, there is no obvious reason why it should not work effectively. Braun describes this process ia detail in a recent publication [BRAUN-1983]. Figure III-24 is a schematic of this process. As the sodium hydroxide is converted to soluble sodium carbonate, the scrubbing solution is removed to a mixing tank where it is contacted with calcium hydroxide. Precipitation of the insoluble calciun carbonate regenerates the sodium hydroxide, which is returned to the scrubbing column. The carbonate cake is incorporated in cement for long-term disposal.

The potential difficulties of this method are as follows:

multiple and difficult steps would be required from collection to packaging; (2) decontamination from the scrubber solution or filter cake of other airborne radioactive wastes would be difficult; (3) $\mathrm{NO}_{x}$ species would deplete the caustic solution; and (4) approximately $200 \mathrm{~g}$ of C-14 would be disposed of in 265 tons of concrete (a great deal of waste generation for $850 \mathrm{ci}$ of radioactive material) [BROWN-1980].

\section{b. Caustic Slurry Scrubbing [CROFF-1976; NOTZ-1980A, -1980B; HOILADAY-1979; CHEW; PATCH; SHEPPARD]}

Caustic slurry scrubbing is similar to the above process in that it involves caustic scrubbing with $\mathrm{CaCO}_{3}$ as its product, but it is different in that ${ }^{14} \mathrm{CO}_{2}$ is contacted directly with an aqueous slurry of calcium hydroxide (or barium hydroxide) in a stirred cell contactor. Moreover, no $\mathrm{NaOH}$ would be present in the $\mathrm{CaCO}_{3}$ cake; $\mathrm{Ca}(\mathrm{OH})_{2}$ would be present instead. Figure III-25 is a schematic of the caustic slurry scrubbing process. Advantages and disadvantages for this process are similar to those of caustic scrubbing. The amount of $\mathrm{CaCO}_{3}$ produced would be essentially identical for both processes.

$$
\text { c. Molecular Sieve Adsorption [NOTZ-1980A, -1980B] }
$$

A molecular sieve bed would collect both $\mathrm{CO}_{2}$ and $\mathrm{Kr}-85$ fros $\mathrm{s}:$ $\mathrm{NO}_{\mathrm{x}}$-depleted, dry off-gas stream. Experiments under way to separate $\mathrm{Kr}-\$ 5 ; \mathrm{i}: \mathrm{im}$ $1{ }^{14} \mathrm{CO}_{2}$ are based on the fact the $\mathrm{CO}_{2}$ is more energetically bound to the $\mathrm{i} i \mathrm{i}=$ type $5 \mathrm{~A}$ molecular sieve used in the sorption bed. Once the $\mathrm{CO}_{2}$ is separsis: from $\mathrm{Kr}-85$, it. will be removed from the gas stream by caustic scrubbinz solidified as $\mathrm{CaCO}_{3}$. Use of a molecular sieve results in the concents: $\mathrm{A}: \mathrm{A}$ $\mathrm{CO}_{2}$ in the off-gas stream being much higher than that of the originsl sts stream; this condition may allow a scaledown of the caustic scrubbing sos.s.s. 


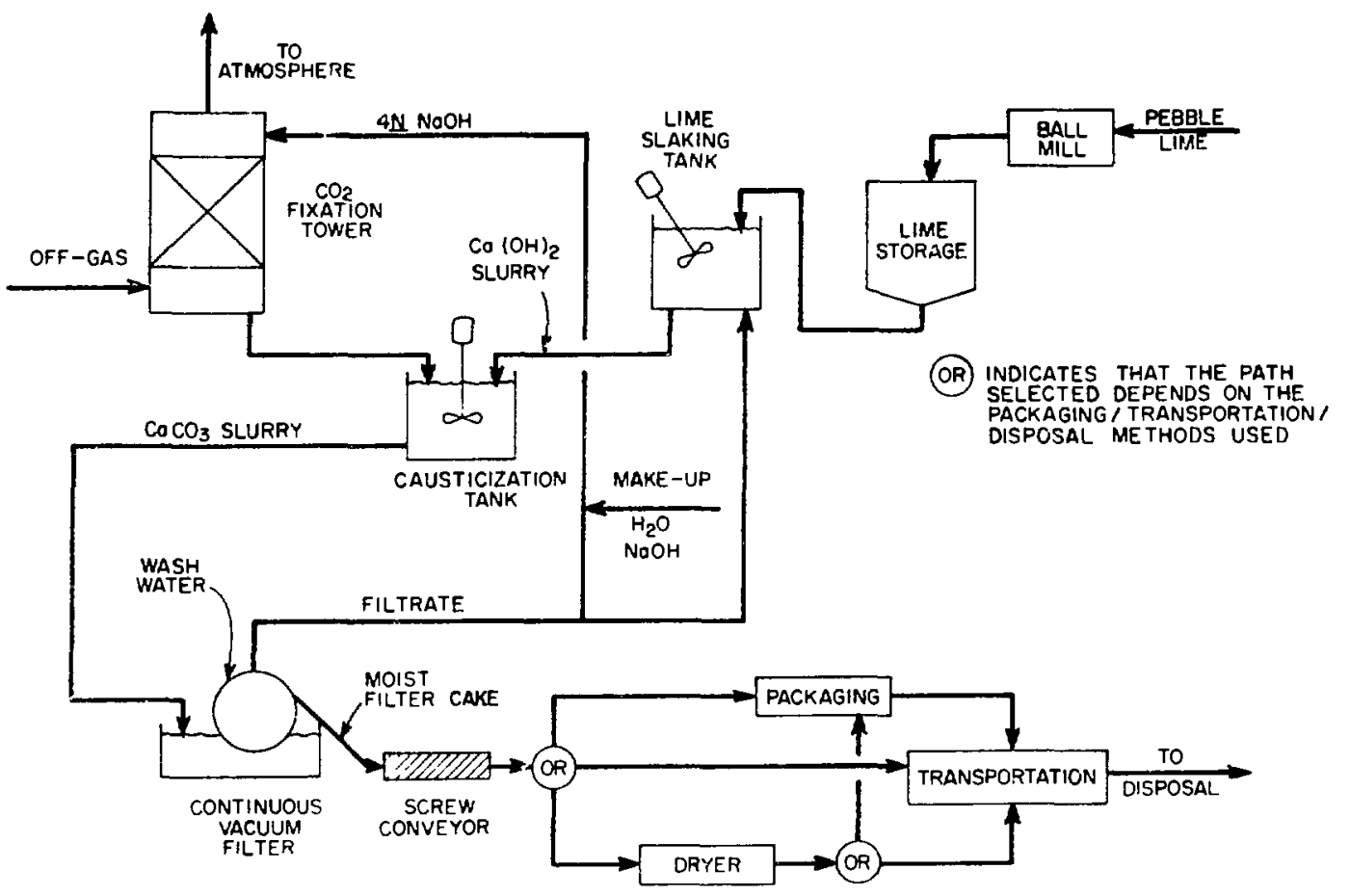

Fig. III-24. Schematic of the Double Alkali $\mathrm{CO}_{2}$ Fixation Process [CROFF-1976].

However, the molecular sieve complicates the collection process further. The amount of $\mathrm{CaCO}_{3}$ waste generated would be the same as for the processes described above. A more detailed deseription of this process can be found in Section III.A.2.d.

\section{d. Fluorocarbon Absorption [STEPHENSON-1976, -1977; LITTLE]}

Fluorocarbon absorption was primarily designed for the capture of $\mathrm{Kr}-85$, but does effectively trap $\mathrm{CO}_{2}$ simultaneously, with lesser amounts of Xe, $\mathrm{Ar}, \mathrm{O}_{2}$, and $\mathrm{N}_{2} \mathrm{O}$ also being collected. These gases are absorbed from the off-gas stream at pressures of 6 to $20 \mathrm{~atm}$. When the pressure is dropped to $1 \mathrm{~atm}$, the desorbed gases are separated into high-boiling fractions $\left(\mathrm{CO}_{2}\right.$ s $\mathrm{Xe}, \mathrm{N}_{2} \mathrm{O}$ ) and low-boiling fractions $\left(\mathrm{Kr}, \mathrm{Ar}, \mathrm{O}_{2}\right)$; the $\mathrm{CO}_{2}$ is collected from the high-boiling fraction by molecular sieves and is subsequently converted to a $\mathrm{CaCO}_{3}$ waste form. The amount of $\mathrm{CaCO}_{3}$ waste collected from the process is similar to that for the collection processes described above. A more detailed description of this process can be found in Section III.A.2.c.

$$
\text { e. Adsorbent Bed Fixation [HAAG-1981A, -1981B, -1983; }
$$

The major advantage to adsorbent bed fixation is its simplicity. As $\mathrm{CO}_{2}$ passes through a bed of $\mathrm{Ba}(\mathrm{OH})_{2} \cdot 8 \mathrm{H}_{2} \mathrm{O}$ chips, it is simultaneously sorbed 
and inmobilized as $\mathrm{BaCO}_{3}$ :

$$
\mathrm{CO}_{2(\mathrm{~g})}+\mathrm{Ba}(\mathrm{OH})_{2} \cdot 8 \mathrm{H}_{2} \mathrm{O}_{(\mathrm{s})} \rightleftharpoons \mathrm{BaCO}_{3}(\mathrm{~s})+\mathrm{H}_{2}{ }_{(\mathrm{g})}
$$

The process is capable of decontamination factors $>1000$ and $>99 \%$ transformation of $\mathrm{Ba}(\mathrm{OH})_{2} \cdot 8 \mathrm{H}_{2} \mathrm{O}$ to $\mathrm{BaCO}_{3}$.

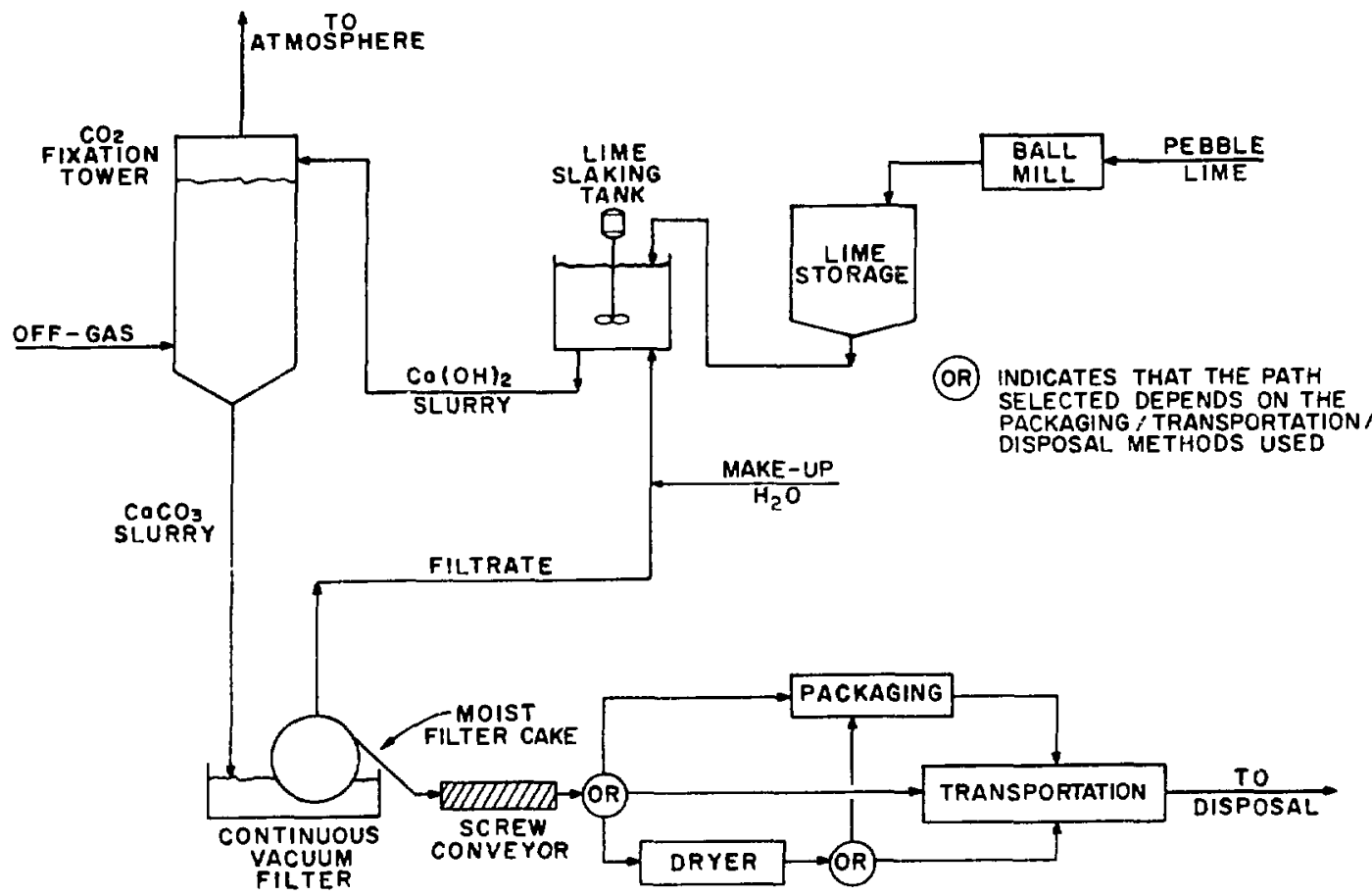

Fig. III-25. Schematic of the Direct $\mathrm{CO}_{2}$ Fixation Process [CROFF-1976].

Because the molecular weight of $\mathrm{BaCO}_{3}$ is twice that of $\mathrm{CaCO}_{3}$, the process will develop twice as much (by weight) solid carbonate waste. However, because the density of $\mathrm{BaCO}_{3}$ is higher than that of $\mathrm{CaCO}_{3}$ and because the re is no aqueous slurry to contend with, the amount of concrete waste produced would be 5-10 times less than that produced by caustic scrubbing; $\mathrm{BaCO}_{3}$ is even more thermally and chemically stable than $\mathrm{CaCO}_{3}$ and has a somewhat lower aqueous solubility.

From laboratory-scale investigations, Haag et al. [HAAG-1983] recommend process conditions that involve a "window" bounded by a maximum relative humidity of $60 \%$ and a minimum relative humidity determined by the dissociation pressure of $\mathrm{Ba}(\mathrm{OH})_{2} \cdot 8 \mathrm{H}_{2} \mathrm{O}$. Perhaps a good choice of conditions, based upon the data presented by [HAAG-1983], is a temperature of about $20^{\circ} \mathrm{C}$ and a relative humidity of about $45 \%$. 
The removal of $\mathrm{CO}_{2}$ from mixtures with gaseous nitrogen has been investigated for possible application to the cleanup of CANDU reactor cooling systems [CHEH]. This process involves reaction of $\mathrm{CO}_{2}$ with a packed bed of solid $\mathrm{Ca}(\mathrm{OH})_{2}$. The results were concluded to be promising for application. Sufficient information to allow comparing $\mathrm{Ca}(\mathrm{OH})_{2}$-adsorbent-bed fixation against the other collection processes described here is not available, however.

\section{Immobilization of Carbon}

\section{a. $\mathrm{CaCO}_{3}$ and $\mathrm{BaCO}_{3}$ in Concrete}

\section{(1) Solubility Data}

The carbonate salts of barium ion and calcium ion have low aqueous solubilities. Solubility data for these two salts measured in ambient atmosphere by several researchers are presented in Fig. III-26; the Iines through the points were drawn by eye to show the unusual retrograde temperature dependence of $\mathrm{CaCO}_{3}$ solubility and the more-typical temperature dependence of $\mathrm{BaCO}_{3}$ solubility. The scatter of data for solubility measurements by different experimenters may be explained by different aqueous concentrations of carbon dioxide. Because of the importance of the reaction

$$
\mathrm{CO}_{3}^{2-}+\mathrm{CO}_{2}+\mathrm{H}_{2} \mathrm{O} \rightleftharpoons 2 \mathrm{HCO}_{3}^{-}
$$

to the solubility of carbonate salts, the atmosphere in which their solubility is measured is very important. The effect of $\mathrm{CO}_{2}$ partial pressure on calcite solubility is demonstrated in Fig. III-27.

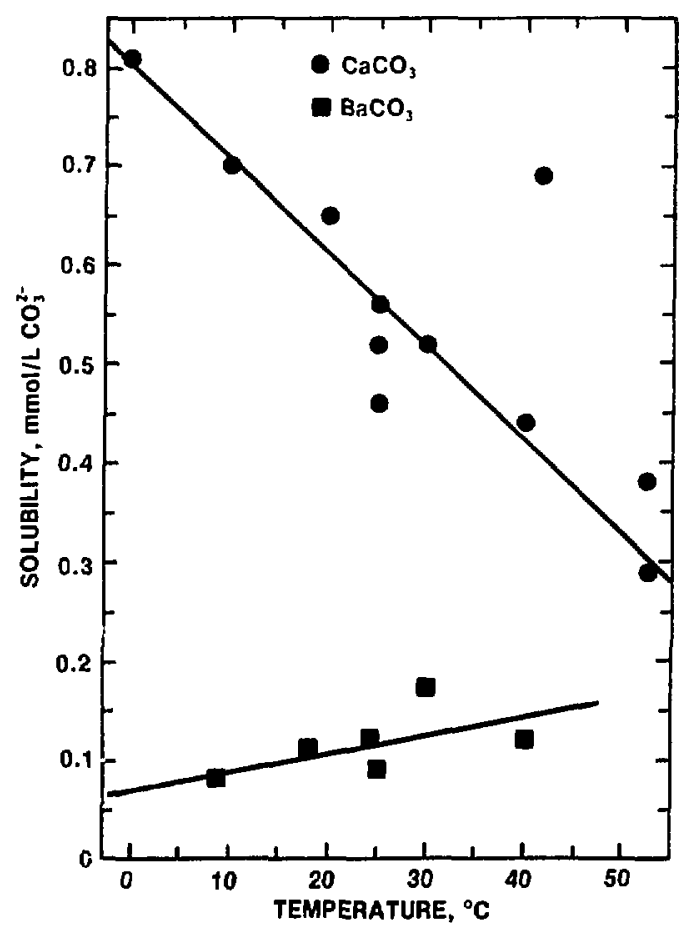

Fig. III-26.

Solubility of $\mathrm{CaCO}_{3}$ and $\mathrm{BaCO}_{3}$ under Ambient Atmosphere vs. Temperature [GMELIN-1960,-1961; LINRE; STEPHEN; SIDGEWICK] . 


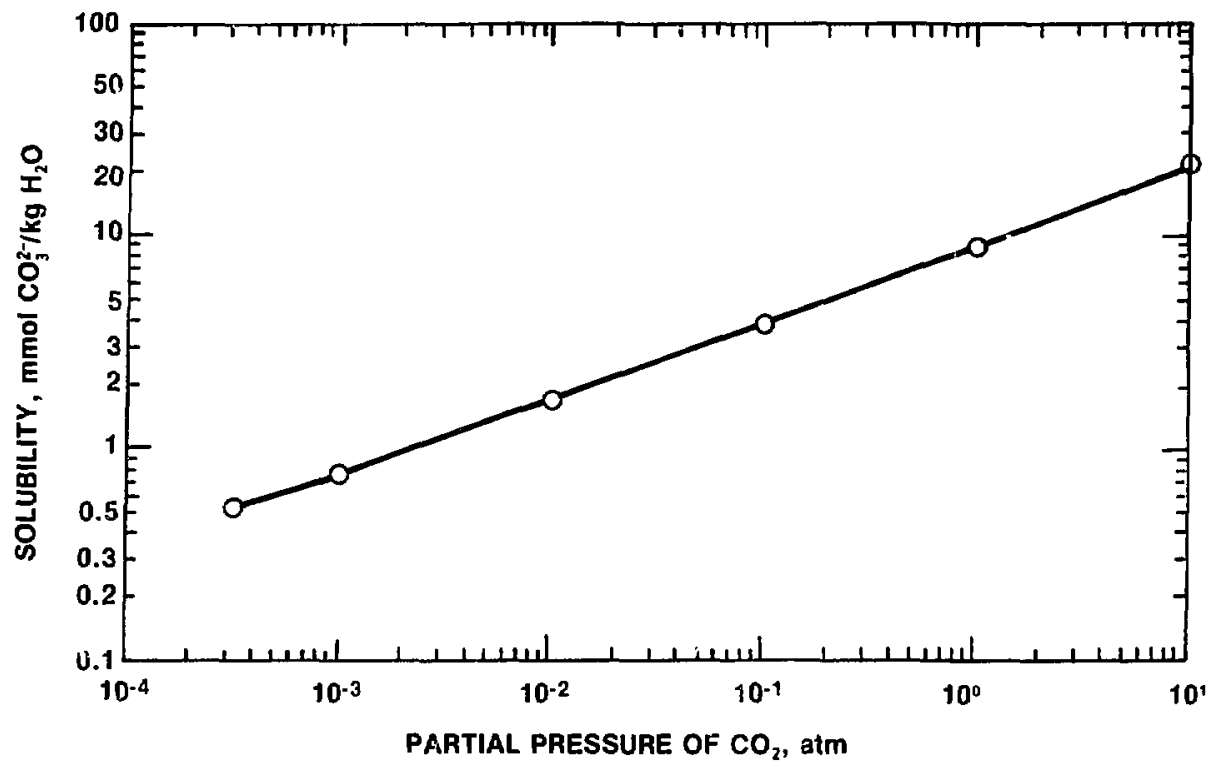

Fig. III-27. The Solubility of Calcite vs. the Partial Pressure of $\mathrm{CO}_{2}$ above the Solution at $25^{\circ} \mathrm{C}$ [iINKE].

\section{(2) Thermal Stability}

The thermal decomposition of both $\mathrm{BaCO}_{3}$ and $\mathrm{CaCO}_{3}$ occurs

by the same process:

$$
\mathrm{MCO}_{3(\mathrm{~s})} \rightleftharpoons \mathrm{MO}(\mathrm{s})+\mathrm{CO}_{2(\mathrm{~g})}
$$

The temperature needed to initiate thermal decomposition to the oxide is, therefore, dependent on the partial pressure of carbon dioxide [DUVAL, SIDGEWICK, LIPTAY]. Dry $\mathrm{CaCO}_{3}$, as calcite, begins to lose $\mathrm{CO}_{2}$ at about $500^{\circ} \mathrm{C}$ and is converted to $100 \% \mathrm{CaO}$ at a temperature between 680 and $810^{\circ} \mathrm{C}$, depending on the rate of heating and the mass of the sample [DUVAL]. In a $\mathrm{CO}_{2}$ gas flow, temperatures at the onset of decomposition can be increased to $2900^{\circ} \mathrm{C}$.

At temperatures up to $1000^{\circ} \mathrm{C}, \mathrm{BaCO}_{3}$ is stable to decomposition. Its natural mi neral form, witherite, began to show signs of $\mathrm{CO}_{2}$ loss at $1075^{\circ} \mathrm{C}$ in air and $975^{\circ} \mathrm{C}$ in a $\mathrm{N}_{2}$ stream [DUVAL]. If the witherite is kept under high $\mathrm{CO}_{2}$ pressure to stof its thermal decomposition, a melting point of $1740^{\circ} \mathrm{C}$ is observed [SIDGEWICK]. According to Duval [DUVAL], $\mathrm{BaCO}_{3}$ formed by precipitation from aqueus solution retains water tenaciously. Although $99.6 \%$ of the water was removed by heating to $400^{\circ} \mathrm{C}$, the remainder was not removed until further heating to $681^{\circ} \mathrm{C}$. There is no weight loss of dry $\mathrm{BaCO}_{3}$ between 20 and $1000^{\circ} \mathrm{C}$. 


\section{(3) Leaching of $\mathrm{C}-14$ from $\mathrm{CaCO}_{3}$ and $\mathrm{BaCO}_{3}$ in Concrete}

Two sets of leach tests have been performed at PNL by Scheele at al. [SCHEELE-1982, PLATT-1979B, -1979C; CHIKALLA-1982]. In the first set of experiments, the objective was to measure, by a Plackett-Burman experimertal design, the effect of various parameters on the leach rate of $14 \mathrm{CO}_{2}{ }^{2-}$ from a concrete monolith. These parameters are 1 isted below in the relative order of importance to $\mathrm{C}-14$ leaching. The numbers in parentheses are "factor effects." The larger the iagnitude of the factor effect, the greater is the influence of that parameter on the leach rate. A positive sign means an increase in this parameter increases the leach rate; a negative sign indicates an inverse relationship between the parameter and the leach rate. The parameters studied were:

(1) initial carbon dioxide concentration in the leachate $\left(+7.45 \times 10^{-3}\right)$,

(2) concentration of the carbonate in the concrete $\left(+1.59 \times 10^{-3}\right)$,

(3) concentration of strontium nitrate added to the concrete $\left(-1.44 \times 10^{-3}\right)$,

(4) concentration of barium nitrate added to the concrete $\left(-1.37 \times 10^{-3}\right)$,

(5) solubility of the carbonate salt added to the concrete ([SCHEELE-1982], $\mathrm{SrCO}_{3}$, solubility $=1.0^{-5} \underline{\mathrm{M}} ; \mathrm{K}_{2} \mathrm{CO}_{3}$, solubility $=8.1 \mathrm{M})\left(+4.19 \times 10^{-4}\right)$, and

(6) addition of sodium resinate--an air entraining agent inat changes the pore structure of the concrete--to the concrete $\left(+5.51<10^{-5}\right)$.

All of the factors above had a measurable effect on the leach rate of the carbonate except for sodium resinate addition, whose effect was considered negligible. The experimental conditions and fraction of carbonate leached after $25 \mathrm{~d}$ are presented in Table III-34.

In a second set of experiments, a static leach test was performed on $\mathrm{CaCO}_{3}$ in portland type III cement ( 2.5 mmol $\mathrm{CaCO}_{3} / \mathrm{s}$ dry cement) in different leachates (distilled water, river water, sea water). These data are shown in Fig. III-28. The drop in $14{ }_{4} \mathrm{CO}_{3}{ }^{2-}$ in solution with time for experiments $\#_{3} 3$ and $\# 4$ is attributed to isotopic dilution of $14 \mathrm{CO}_{3}{ }^{2-}$ by $\mathrm{CO}_{2}$ from the atmosphere in those basic solutions.

In Fig. III-29 are the comparable IAEA leach studies for $\mathrm{BaCO}_{3}$ and $\mathrm{CaCO}_{3}$ in concrete (both at a concentration of $2.5 \mathrm{mmol} \mathrm{CO}_{3}{ }^{2-} / \mathrm{g}$ dry cement). The initial leaching rate of the two barium carbonate samples was much higher than that of the two calcium carbonate samples. After $5 \mathrm{~d}$, the ratio of the leach rate of $\mathrm{BaCO}_{3}$ in concrete to that of $\mathrm{CaCO}_{3}$ in concrete dropped to a factor of 2 ; the leach rates were determined to be $7.2 \times 10^{-6} \mathrm{~cm} / \mathrm{d}$ for $\mathrm{BaCO}_{3}$ and $3.9 \times 10^{-6} \mathrm{~cm} / \mathrm{d}$ for $\mathrm{CaCO}_{3}$. 
Table III-34. Summary of Carbonate Leaching Experiments [PLATT-1979C]

\begin{tabular}{|c|c|c|c|c|c|c|c|}
\hline \multirow[b]{2}{*}{ Trial } & \multirow{2}{*}{$\begin{array}{l}\text { Car- } \\
\text { bonate } \\
\text { Salt } \\
\text { Solu- } \\
\text { tility, } \\
\quad \text { M }\end{array}$} & \multirow[b]{2}{*}{$\begin{array}{l}\mathrm{CO}_{2} \text { in } \\
\text { Leachant }\end{array}$} & \multicolumn{4}{|c|}{ Addition, $\mathrm{g} / \mathrm{g}$ Dry Cement } & \multirow{2}{*}{$\begin{array}{l}\text { Cumulative } \\
\text { Fraction } \\
\text { Carbonate } \\
\text { Isached } \\
\text { After } \\
25 \mathrm{~d}, \mathrm{~cm}\end{array}$} \\
\hline & & & $\begin{array}{c}\text { Car- } \\
\text { bonate }\end{array}$ & $\begin{array}{l}\text { Stron- } \\
\text { tium } \\
\text { Nitrate }\end{array}$ & $\begin{array}{c}\text { Sodium } \\
\text { Resonate }\end{array}$ & $\begin{array}{l}\text { Barium } \\
\text { Nitrate }\end{array}$ & \\
\hline 1 & $10^{-5}$ & Ambient & 0.15 & 0.14 & 0.01 & 0.03 & $2.54 \mathrm{E}-5$ \\
\hline 2 & $10^{-5}$ & Saturated & 0.03 & 0.14 & 0.01 & 0 & $6.70 \mathrm{E}-3$ \\
\hline 3 & 8.1 & Saturated & 0.15 & 0.14 & 0 & 0 & $8.55 E-3$ \\
\hline 4 & $10^{-5}$ & Saturated & 0.15 & 0 & 0 & 0 & $1.19 \mathrm{E}-2$ \\
\hline 5 & $10^{-5}$ & Ambient & 0.15 & 0 & 0 & 0.03 & $2.25 E-4$ \\
\hline 6 & $10^{-5}$ & Ambient & 0.03 & 0 & 0.01 & 0 & ت.09E-4 \\
\hline 7 & 8.1 & Ambient & 0.03 & 0.14 & 0 & 0.03 & $4.19 \mathrm{E}-4$ \\
\hline 8 & 8.1 & Saturated & 0.03 & 0 & 0.01 & 0.03 & $8.86 \mathrm{E}-3$ \\
\hline 9 & 8.1 & Ambient & 0.15 & 0.14 & 0.01 & 0 & $1.41 E-3$ \\
\hline 10 & $10^{-5}$ & Saturated & 0.03 & 0.14 & 0 & 0.03 & $3.69 \mathrm{E}-3$ \\
\hline 11 & 8.1 & Saturated & 0.15 & 0 & 0.01 & 0.03 & $7.79 \mathrm{E}-3$ \\
\hline 12 & 8.1 & Ambient & 0.03 & 0 & 0 & 0 & $1.80 \mathrm{E}-4$ \\
\hline
\end{tabular}




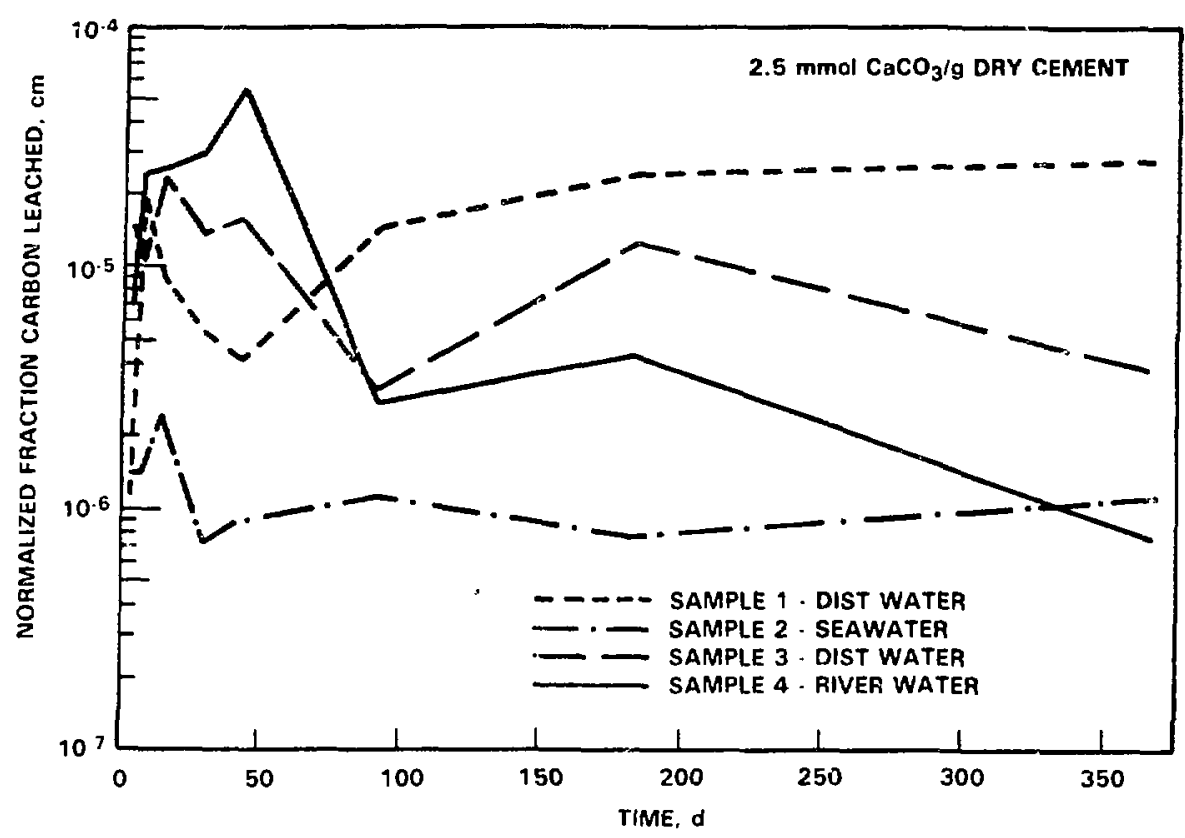

Fig. III-28. C-i4 Static Leach Studies of ConcreteEncapsulated $\mathrm{CaCO}_{3}(2.5 \mathrm{mmol}$ $\mathrm{CaCO}_{3} / \mathrm{g}$ dry portland cement) [SCHEELE-1982].

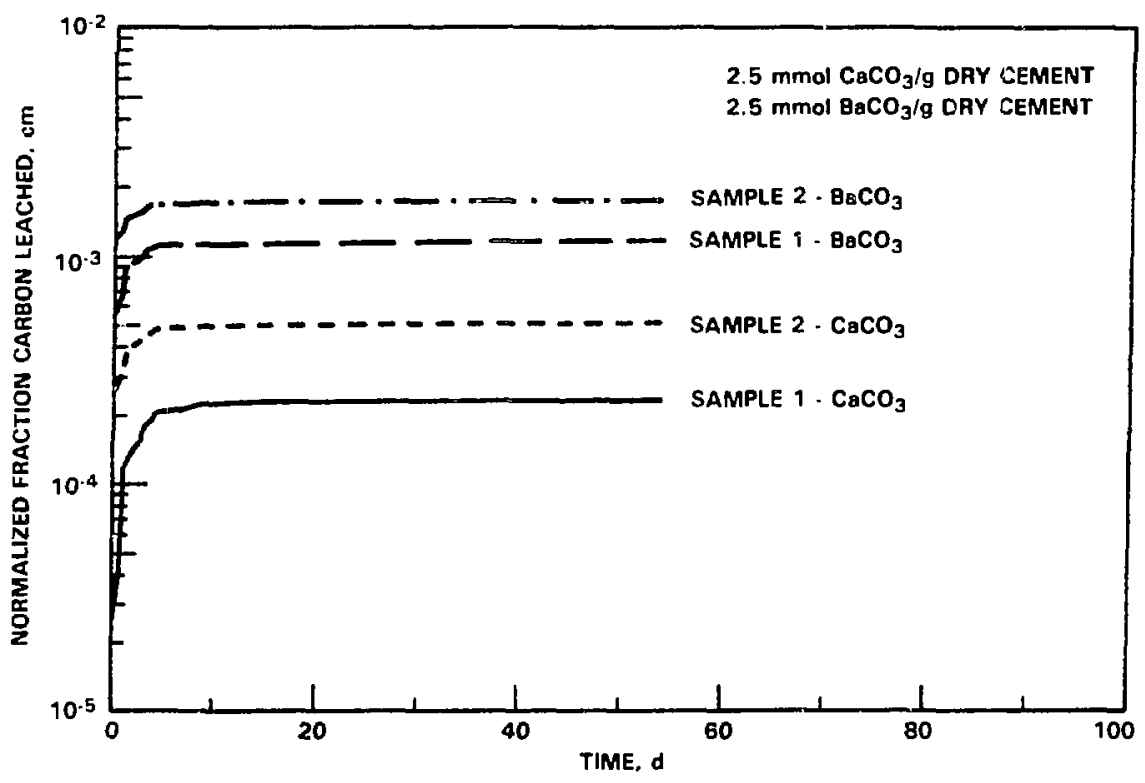

Fig. III-29. C-14 IAEA Leach Studies of ConcreteEncapsulated $\mathrm{BaCO}_{3}$ and $\mathrm{CaCO}_{3}$ (2.5 mmol C/g dry Portland Cement) [SCHEELE-1982]. 


\section{b. Alternative Carbon Waste Forms}

No sat isfactory alternatives to the waste forms described above are presently being considered for C-14 long-term disposii. Croff [CROFF-1976] looked at the possibility of disposal of $\mathrm{CaCO}_{3}$ or $\mathrm{BaCO}_{3}$ with no matrix in 55-gal steel drums or disposal of $\mathrm{Ca}^{14} \mathrm{CO}_{3}$ in grouts without cortainers but rejected these options because of their low resistance to leaching of $14 \mathrm{CO}_{3}{ }^{2-}$.

\section{c. Migration of Carbonate in Geological Fozmations}

Allard et al. [ALLARD-1981] studied the sorption of $\mathrm{H}^{14} \mathrm{CO}_{3}$ from simulated granitic groundwater $(\mathrm{pH}=7.2-8.5)$ by various common minerals and cement. Most groundwaters have concentrations of carbonate plus bicarbonate in the range of $1-6 \mathrm{mM}(60-100 \mathrm{mg} / \mathrm{L})$ and are slightly undersaturated in respect to $\mathrm{MgCO}_{3}(s)$ and $\mathrm{CaCO}_{3}(\mathrm{~s})$. The following equilibria are important to the concentration of carbonate and bicarbonate in groundwaters and to the sorption of $\mathrm{C}-14$ from these groundwaters:

$$
\begin{array}{ll}
\mathrm{Ca}^{2+}+\mathrm{HCO}_{3}{ }^{-} \rightleftharpoons \mathrm{CaHCO}_{3}{ }^{+} & \log \mathrm{K}=1.0 \\
\mathrm{Ca}^{2+}+\mathrm{CO}_{3}^{2-} \rightleftharpoons \mathrm{CaCO}_{3} & \log \mathrm{K}=3.15 \\
\mathrm{Ca}^{2+}+\mathrm{CO}_{3}^{2-} \rightleftharpoons \mathrm{CaCO}_{3(\mathrm{~s})} & \log \mathrm{K}=-8.35 \\
\mathrm{Mg}^{2+}+\mathrm{HCO}_{3}{ }^{2} \rightleftharpoons \mathrm{MgHCO}_{3}{ }^{2} & \log \mathrm{K}=0.95 \\
\mathrm{Mg}^{2+}+\mathrm{CO}_{3}{ }^{2-} \rightleftharpoons \mathrm{MgCO}_{3} & \log \mathrm{K}=2.88 \\
\mathrm{Mg}^{2+}+\mathrm{CO}_{3}{ }^{2-} \rightleftharpoons \mathrm{MgCO}_{3(\mathrm{~s})} & \log \mathrm{K}_{s}=-7.46
\end{array}
$$

where $\mathrm{K}$ is the equilibrium constant for the reaction of the aqueous soluble species, and $\mathrm{K}_{s}$ is the solubility product. The sorption of $\mathrm{HCO}_{3}{ }^{-}$on the materials listed in Table III-35 is explainable by their calcium ion content. The $K_{d}$ values measured for these materials were far smaller than were measured for the cationic sorption of $\mathrm{Cs}^{+}$and actinides. These results can be explained by (1) an increase of $\mathrm{pH}$ as basic materials (e.g., cement) dissolve to precipitate $\mathrm{CaCO}_{3}$ or (2) cationic exchange of $\mathrm{Na}^{+}$ion in solution for $\mathrm{Ca}^{2+}$ ion in minerals (e.g., bentonite), thereby increasing the $\mathrm{Ca}^{2+}$ ion availability and precipitating $\mathrm{CaCO}_{3}$. The results sugges: that a container of concrete around the concrete-encapsulated $\mathrm{CaCO}_{3}$ or $\mathrm{BaCO}_{3}$ would greatly decrease carbonate migration from the waste form. 
Table III-35. Distribution Coefficient $\left(K_{d}\right)$ vs. Contact Time

\begin{tabular}{|c|c|c|c|c|c|c|c|c|}
\hline \multirow[b]{2}{*}{ Solid } & \multicolumn{8}{|c|}{$\mathrm{K}_{\mathrm{d}}, \mathrm{mL} / \mathrm{s}$} \\
\hline & $0.5 \mathrm{~h}$ & $2 \mathrm{~h}$ & $6 \mathrm{~h}$ & $24 \mathrm{~h}$ & $3 d$ & l wk & 5 wk & $6 \mathrm{mo}$ \\
\hline Stripa granite & & & & & 0 & 0 & 0 & 0 \\
\hline Na-montrorillonite & & & & & 0 & 0 & 0 & 0 \\
\hline $\begin{array}{l}\text { Bentonite/quartz } \\
(10 / 90 \text { ve. ratio })\end{array}$ & & & & & 2.8 & 8.6 & 7.6 & 7.8 \\
\hline Sandy moraine & 1.0 & 0.2 & 0.7 & 0.5 & 0.8 & 1.1 & 2.6 & 2.2 \\
\hline Clayish moraine & 1.9 & 0.7 & 1.3 & 1.4 & 1.3 & 2.0 & 3.0 & 2.3 \\
\hline Calcite & 1.0 & 1.0 & 1.5 & 1.7 & 3.7 & 3.5 & 9.0 & 83 \\
\hline Concrete & & & & & 5.3 & 1600 & $>10^{4}$ & \\
\hline Cement paste & & & & & 7.4 & 1600 & $>10^{4}$ & \\
\hline
\end{tabular}




\section{SYSTEMS FOR PACKAGING, TRANSPORTATION, AND DISPOSAL}

In the preceding sections, a review was presented of the processes for collection of $\mathrm{H}-3, \mathrm{I}-129, \mathrm{C}-14$, and $\mathrm{kr}-85$ from stroams of fuel reprocessing clants and the processes for conversion of the collected wastes into forms with physical and chemical properties that promise to be suitable fur final disposal. The following sections review the possibilities for packaging these waste forms to meet the requirements of transport regulations and the technical criteria for final disposal.

\section{A. Shallow-Land Burial (SLB)}

\section{SLB Practices}

Conventional modes of LLW disposal are examined here for later analysis of whethe: iney would be suitable for disposal of the four airborne wastes. The conventiunal moce of disposing of solid LLW in the U.S. is shallow-land burial, which is distinguished from geologic disposal by the proximity of emplaced waste to the surface of the earth. In brief, the method usually con$\varepsilon$ ists of excavating to create a series of trenches and placing the packaged waste into them. When a trench is filled with waste, it is back-filled with soil and capped to enhance water runotf.

Commercial SLB facilities exist at six sites: West Valley, NY; Morehear, KY; Sheffield, IL; Beatty, NY: Barnwe1l, SC; and Richland, WA. Only the last tirree are receiving wastes now [DOE/NE-0015]. In addition to these commercial ficilities, several facilities are operated by DOE to accommodate wastes generated by DOF and its contractors. Information on site, location, and status of each of these sites is listed in Table IV-1 [DOE/NE-9015].

This method of disposal has generally been practiced with no intention of ready retrievability of the waste at a later date. Furthermore, before the drafting of $10 \mathrm{CFR} 61$, the responsibility of containment was assumed to be that of the soil, not the vessel surrounding the waste form [WHEELER]. More recently, a task force has recommended that an evaluation be done of packaging as containnent barriers [NUREG-02:7]. Wastes in shallow-land burial are subject to water infilitation and movement, erosion, plant root uptake, animal penetration, and human intrusion. Of all these potential radionuclidetransport mechanisms, water has been tradicionally considered to be the principal vehicle by wicic radioactivity can migrate away from the trenches. More-recent irvestisations, honaver, indicate that the chief contribution to radioactivity exposure in the niosphare may be from (1) diffusion of radionuclides to the surface and resuspension of lust, which is ultimately inhaled [HUNTER], or (2), at particularly humid and arable sites, plant root uptake and ingestion of the contaminated food [HOOKER]. Both diffusion and plant root uptake are functions of the presenct of water and the degree of saturation in the soil regions surrounding the waste. Good site selection and desiga practices rhould avoid buried wasce standing in contact with underground water and producing a leachate that will later migrate away. It is particu-arly important to avoid the entry of water into the trench and to minimize the possib:; icy of subsurface flow away from the trench, especially along fractures. ( number of criteria or site characteristics are considered in the selection of a site and in the design of an effective disposal facility. 
Table IV-1. DOE Sites for LLW Disposal

\begin{tabular}{|c|c|c|}
\hline Site & Location & Status \\
\hline Los A:amos National Laboratory ${ }^{a}$ & Los Al amos, NM & Active \\
\hline Brookhaven National Laboratory ${ }^{a}$ & Brookhaven, NY & Inactive \\
\hline Sandia National Laboratories ${ }^{a}$ & Albuquerque, $\mathrm{NM}$ & Active \\
\hline Idaho National Engineering Laboratorya & Idaho Fa1ls, ID & Active \\
\hline Nevada Tast Site & Las Vegas, NV & Active \\
\hline Feed Materials P-oduction Center & Fernald, OH & Active \\
\hline National Lead Company of Ohio & Niagara Falls, NY & Inactive \\
\hline Oak Ridge Gaseous Diffusion Plant & Oak Ridge, TN & Active \\
\hline Oak Ridge National Laboratory & Oak Ridge, TN & Active \\
\hline Oak Ridge Y-12 Planta & Dak Ridge, TN & Active \\
\hline Paducah Gaseous Diffusion Plant & Paducah, KY & Active \\
\hline Portsmouth Gaseous Diffusion Plant & Piketon, OH & Active \\
\hline Weldon Springs & St. Charles County, MO & Inactive \\
\hline Richland Site & Richland, WA & Active \\
\hline Savannah River Plant ${ }^{a}$ & Aiken, SC & Active \\
\hline Lawrence Livermore National Laboratorya & Livermore, CA & Active \\
\hline
\end{tabular}

DOE sites with significant national security responsibilities [DOE/NE-0015]. 
A desirable feature of all sites would be a deep water table. Soil regions that have either high, iow, or alternating high and low permeability may be desirable, depending on topography and climatic conditions at a site. Some sites in the humid eastern U.S. may require a low-permeability (e.g., bentonite) cover [HOORER] or may require the trench or pit to be sloped at one end, with water collection facilities at the low end. Thus, SLB water control techniques are important, and site selection relies greatly on information about the hydrogeology of the site.

In a DOE study [DOE/NE-0015], a typical SLB facility is described as consisting of shallow trenches from 30 to $240 \mathrm{~m}$ long, 6 to $12 \mathrm{~m}$ wide, and $6 \mathrm{~m}$ deep. After a trench is filled with waste, it is covered with 1 to $3 \mathrm{~m}$ of earth and topped with a mounded cap to encourage water drainage. Most trenches asso contain a surn to monitor water levels and permit pumping if necessary. After the trench is covered, vegetation is usually planted to control erosion. Permanent markers at each trench indicate its boundaries and record the total volune and radioactivity of buried waste, as well as the date on whinh the trench was closed. The site is ericlosed by a security fence and is usually surrounded by a buffer zone $i_{n}$ which access is controlled and recorded. Records on wastes received, personnel exposure, and disposal operations are maintained at each site. After a site has been filled, stabilized, and closed, an extended-care plan with regard to environmental monitoring and maintenance is put into effect. Environmental monitoring is used to determine whether the site is performing as predicted and is safely containing the radioactivity in the waste. Corrective measures would be applied if necessary. Maintenance includes various measures to ensure that the integrity of trench caps is maintained. Site security is also maintained for the duration of the extended care.

An NRC study [NUREG-0782] also describes a reference SLB facility. The reference facility is sized to accept a relatively large quantity of waste, i.e., $50,000 \mathrm{~m}^{3}$ of waste per year over a 20-year operating life, or a total volume of $10^{6} \mathrm{~m}^{3}$. This volume corresponds to approximately one-quarter of the total volume of LLW projected in the United States to the year 2000 . Disposal of $1 c^{6} \mathrm{~m}^{3}$ of waste in the reference facility will require about 150 acres of land, which corresponds to the approximate upper bound of the 1 and area for current comnercial disposal facilities. The disposal area at the reference facility includes 58 disposal treaches with dimensions of $180 \mathrm{~m}$ $(591 \mathrm{ft})$ long, $30 \mathrm{~m}(100 \mathrm{ft})$ wide, and $8 \mathrm{~m}(26 \mathrm{ft})$ deep. Support facilities and structures at the oite include (1) an administration building, (2) a health physics/security building, (3) a warehouse, (4) a garage, (5) a waste activities building, ${ }^{*}$ and (6) a storage shed. All structures at the site are onestory metallic structures on concrete pad foundations. Shipments of radioactive waste arrive by truck and are processed at the site on a first-come, first-serve basis. Arriving shipments are inspected for compliance with applicable Federal regulations and waste acceplance criteria established as conditions in the disposal facility license. Waste is randomly emplaced in the trerich, sometimes using cranes and forklifts, and the trench backfilled with dirt removed during trench excavation. Random waste emplacement results in a trench-volume-use efficiency of about $50 \%$. Waste is emplaced to within

* Presumably for handling wastes generated at the site and any repackaging that may be necessary. 
one meter of the top of the trench. Dirt is then backfilled into the trench until the trench cover approximately corresponds to the original grade of the site surface. A 1-m-thick earthen cap is then heaped upon the backfill in the shape of a mound. The earthen cap is covered with natural overburden material as neceisary to provide good drainage characteristics and to cumply with the final contours planned for the site surface. The overburden is reseeded to promote growth of a short-rooted grass cover. After a 20-year operating period, closure (decommissioning) of the facility, which is assumed to require approximately one to two years, involves dismantiing anc decontamination of site buildings, disposal of wastes produced during dismantiement and decontamination operations, and final site seeding and contouring. The licensee also makes a final survey of the disposal area to make sure that direct radiation levels are at essentially background levels. Following closure, the disposal license is terminated and control of the site is transferred to the site owner. For this reference facility, the site owner is assumed to be a state agency which carries out an active institutional control program of surveillance, monitoring, and maintenance for $100 \mathrm{y}$.

Costs for shipping and disposal of LLW have been estimated to be [LEVIN-1981] \$200-300 per 55-gal drum $\left(227-40 \$ / \mathrm{ft}^{3}\right)$. Fees for disposal alone are estimated [LEVIN-1982] to be $\$ 425-700 / \mathrm{m}^{3}\left(\sim 12-20 \$ / \mathrm{ft}^{3}\right)$, with additional surcharges for handling and disposal of packages with external radiation levels in excess of $200 \mathrm{mrem} / \mathrm{h}$.

\section{Local Regulatory Authority for LLW Disposal}

In the past, NRC regulated the activities at all LLW disposal sites, except in cases where NRC had relinquished its authority to "agreement states" [ERDA-76-43A]. Among these states, regulations varied greatly. The current DOE philosophy on management of wastes at DOE facilities, expressed in [DOE5820 ], is to provide general guidance for the implementation of the requirement that DOE field organizations develop site-specific guidelines for disposal operations under their control.

\section{Federal Regulation of LLW Disposal}

Probably the most significant recent developments in Federal actions concerning LLW disposal are the Low-Level Radioactive Waste Policy Act [PL-96573] of December 22, 1980, and the addition of part 61 to Title 10 of the Code of Federal Regulations [10 CFR 61].

\section{a. Low-Level Radioactive Waste Policy Act}

The LLRWPA instructed the Secretary of the DOE to carry out four actions: (1) define the capacity of existing facilities; (2) review the adequacy of all commercial Li.W disposal facilities and make any recommendations necessary to ensure public health and safety; (3) estimate regional transport requirements for LLW shipments, make an inventory of expected types and quantities of LLW, and judge the ability of generators, shippers, and carriers to meet requirements; and (4) evaluate the capabilities of DOE LLW disporal sites to provide interím storage for commercial wastes. 
The LLRWPA declares that each state must provide for the disposal of commercial LLW generated within its borders. It suggests that wastes can be most safely and efficiently managed on a regional basis.

The response of the DOE to the instructions of the LLRWFA is as follows [DOE/NE-0015]. Storage of the LLW expected through the year 2000 will require additional disposal capacity. Indeed, within 10 years, there will be a need for 5-7 sites, in addition to the three that are now in operation. The technology for safe disposal by SLB is now available, and lessons learned from practice in SLE since 1962 will enhance its safety. The use of regional sites should reduce distances between waste source and final disposal site, costs of waste management, and =isks of radiation exposure to the public up to $50 \%$. Temporary storage of commercial LLW at DOE LLW disposal facilities is possible, at costs of up to $\$ 2000 / \mathrm{m}^{3}$, depending on measures needed to control environmental impacts and to assure protection of national security. of course, the passage of legislation that would authorize such disposal is required.

Although NRC has issued technical guidelines for SLB in $10 \mathrm{CFR}$ 61 , the task of setting a standard for exposure from SLB falls under the purview of EPA. The progress of EPA in developing a standard for che environmental impact of LLW disposal was reviewed by Galpin [GALPIN]. He acknowledged that a number of Federal and State agencies are anticipating the EPA standards and that the EPA has been given the responsibility for setting them. The EPA sees several issues that must be resolved in the development of the standard: (1) determination of a limit of exposure to the general public; (2) determination of whether to set a de minimus* level, below which disposal does not require isolation from the environment; (3) determination of what form the standard should be expressed in, e.g., annual maximum individual exposure, 1 ifet ime dose commitment, release rate, or total release; and (4) determination of whether the standard should apply to all facilities or only to new facilities. To help EPA make these determinations, ORNL is making a risk assessment for near-surface disposal and TRW Inc. is making a risk assessment, under contract to EPA, of eight methods for disposal of LLW. The EPA plans to investigate the question of how technology can reduce the risk of LLW and what this technology will cost. The agency also plans to determine the economic impact of whatever standard it recommends. All of these analyses are to be presented in a draft EIS to support the proposed standard. Following public hearings on this matter, the EPA will issue a final standard.

\footnotetext{
"Presumably a shortening of the Latin phrase, "de minimus non curat lex," meaning "the law is not concerned with trifles".
} 


\section{b. NRC Regulations [10 CFR 61]}

Wastes addressed by $10 \mathrm{CFR} 61$ are low-level wastes containing source, ${ }^{*}$ special nuclear, ${ }^{\dagger}$ or by-product material ${ }^{\ddagger}$ acceptable for disposal in a land-disposal facility. Furthermore, low-level waste has the same meaning as that described in the Low-Level Radioactive Waste Policy Act [PL 96-573], i.e., material not classified as high-level radioactive waste, TRU waste, spent nuclear fuel, or by-product material as defined in Section 1le(2) of the Atomic Energy Act.

The main items contained in 10 CFR 61 include: (1) procedures, terms, criteria, and conditions upon which NRC will issue a license for a nearsurface disposal facility and also a number of additional rules not directly related to the question of whether airborne wastes would be accepted or appropriately disposed of in this type of facility; (2) performance objectives for a near-surface disposal facility, including protection of operators, protection of general population, and preservation of the stability of the disposal site; (3) technical requirements intended to assure achieving the performance objectives listed below. The information most important to the analysis of the acceptability of airborne wastes is contained in the last two items-performance objectives and technical requirements.

The performance objectives are (1) protection of operators through compliance with the standards for radiation protection set out in [10 CFR 20]; (2) protection of the general population through compliance with the rules that an annual dose, from releases, for any member of the public m:ust not exceed 25 mrem to the whole body, $75 \mathrm{mrem}$ to the thyroid, and $25 \mathrm{mrem}$ to any other organ; and (3) preservation of the long-term stability of the site by eliminating the need for ongoing active maintenance after closure. This last stipulation will have a direct bearing on the choice of packaging for any waste to be disposed of in a near-surface facility.

The important technical requirements are expressed in a waste classification system based on radioactive concentrations and on a listing of acceptable waste characteristics.

The classification of wastes in 10 CFR 61.55 , by radioactivity concentration, is intended to provide criteria for deciding the treatment to

\footnotetext{
* Source material is (1) uranium or thorium, or any combination thereof, in any physical or chemical form or (2) ores that contain by weight one twentieth of one percent $(0.05 \%)$ or more of uranium, thorium, or any combination thereof. Source material does not include special nuclear material.

${ }^{\dagger}$ Special nuclear material is (1) plutonium, uranium-233, iranium enriched in the isotope 233 or in the isotope 235 , and any other material which the NRC, determines to be special nuclear material, or (2) any material artificially enriched by any of the foregoing.

$\ddagger$

By-product material is the tailings or wastes produced by the extraction or concentration of uranium or thorium from any ore processed primarily for its source material content, including discrete surface wastes resulting from uranium solution extraction processes.
} 
be given a waste, namely, its burial depth, location within the facility, waste form, and packaging. For fuel cycle wastes, economic considerations are likely to result in the production of wastes with high specific activity; therefore, the most important items for the present discussion are the speci fications of maximum concentration, reproduced in Table IV-2. Since the regulation states that concentrations can be averaged over the volume of the package, the concentration limit can be multiplied by the volume of the package to determine the allowable total quantity of radioactivity per package. In the case of a 55-gal drum, a package commonly used in near-surface disposal (volume $2: 10^{5} \mathrm{~cm}^{3}$ ), the specific activity values, in units of $\mu \mathrm{Ci} / \mathrm{cm}^{3}$, $\mathrm{can}$ be multiplied by $2 \times 10^{5}$ to estimate the total quantity of an isotope permitted per drum. Furthermore, estimates of the production rate of the isotopes, in units of $\mathrm{Ci} / \mathrm{GW}(e)-y$, can be used with the specific activities in this table to calculate the amount of disposal space, or number of packages of chosen volume, required annual ly if airborne wastes are routed to a nearsurface disposal facility and if all isotopes are available at acceptable concentrations. For $\mathrm{I}-129$ and $\mathrm{C}-14$, however, concentrations in the waste forms developed by $R \& D$ programs may be higher than the acceptable levels set by disposal facilities. Recent information (see footnote a of Table IV-2) indicates that specifications for $\mathrm{Kr}-85$ from fuel reprocessing may be set at some future time.

Table IV-2. Maximum Concentrations of Airborne Wastes in Near-Surface Disposal Specified by 10 CFR 61

\begin{tabular}{|c|c|c|c|}
\hline Isotope & $\begin{array}{c}\text { Concentration Limit } \\
\text { Defining } \mathrm{Class} \mathrm{A} \\
\text { Waste, } \mathrm{Ci} / \mathrm{m}^{3}\end{array}$ & $\begin{array}{l}\text { Concentration Limit } \\
\text { Defining Class B } \\
\text { Waste, } \mathrm{Ci} / \mathrm{m}^{3}\end{array}$ & $\begin{array}{l}\text { Concentration Limit } \\
\text { Defining Class C } \\
\text { Waste, } \mathrm{Ci} / \mathrm{m}^{3}\end{array}$ \\
\hline$K r-85$ & $\mathbf{a}$ & a & $\mathbf{a}$ \\
\hline$I-129$ & $\leq 0.008$ & - & $0.008-0.08$ \\
\hline $\mathrm{H}-3$ & $\leq 40$ & $>40^{b}$ & b \\
\hline$c-14$ & $\leq 0.8$ & - & $0.8-8$ \\
\hline \multicolumn{4}{|c|}{$\begin{array}{l}\text { The limits listed in [ } 10 \text { CFR } 61] \text { are not intended to apply to the mil- } \\
\text { lions of curies of Kr- } 85 \text { that would require management from fuel repro- } \\
\text { cessing; the NRC intends, at some future time, to assess krypton- } \\
\text { disposal technology and establish disposal requirements for this source } \\
\text { of Kr-85. } \\
\text { bo maximum established; the permissible quantity is to be determined by } \\
\text { radiation and heat generation. }\end{array}$} \\
\hline
\end{tabular}

The waste characteristics 1 isted in 10 CFR 61.56, as minimum acceptable requirements, intended to facilitate handling and provide protection of health and safety to personnel at the disposal site, can be summarized as follows:

(1) Waste cannot be packaged in cardboard or fiberboard boxes. 
(2) Packages containing liquids must aiso contain absorbent materials sufficient to absorb twice the volume of contained liquid.

(3) Solid wastes containing liquid must contain as little free-standing and noncorrosive liquid as is reasonably achievable, but in no case must the liquid exceed $1 \%$ of the volume.

(4) Wastes must not be capable of detonation, explosive decomposition, or explosive reactions in exposure either to normal temperatures and pressures or to water.

(5) Waste must not be capable of generating quantities of toxic gases.

(6) Pyrophoric materials must be packaged, treated, or prepared to render them nonflammable.

(7) Wastes in gaseous form cannot exceed pressures of 1.5 atm at $20^{\circ} \mathrm{C}$.

(8) Wastes in gaseous form cannct exceed $100 \mathrm{Ci}$ per container.

(9) Wastes containing biological, pathogenic, or infectious materials must be treated to reduce the hazard as far as practicable.

Additional rules are given to provide stability of the disposal site by requiring stability of the waste forms:

(1) Wastes must have structural stability provided either through stability of waste form or container.*

(2) Where stability is provided by the container, liquids must not exceed $1 \%$ of the volume. Where stability is provided by the waste form, iiquids must not exceed $0.5 \%$ of the volume.

(3) Void space, within the waste and also between the waste and containers, must be minimized.

\section{B. Greater Confinement Disposal (GCD)}

\section{Development of GCD}

\section{a. Need for a Greater Confinement Concept}

The status of the development of the GCD concept was reviewed in recent conferences [LARGE-1981, -1982] on LLW disposal. The GCD concept is being explored for several reasons: (1) near-surface disposal may be inadequate for so.te types of LLW, (2) depth is likely to enhance the safety of storage, and (3) GCD may offer an economic and safe alternative to deep geological

${ }^{*}$ For $\mathrm{Class} B$ and $\mathrm{Cl}$ ass $\mathrm{C}$ wastes, either the waste forms or the containers must naintain gross physical properties and identity for $300 \mathrm{y}$. 
disposal for high specific activity wastes. Low-level wastes not considered suitable for SLB, even though they are non-TRU wastes, include those with specific activities that are too high. These wastes are thought to present significant risks if disposed of by SLB as a result of potential for exposure through erosion, transport by groundwater or vaporization, intrusions by plants and animals, and inadvertent human intrusion [HUNTER]. In the past, deep-geologic repositories have been viewed as the best destination for these types of wastes, but recently, it has been postulated that a more-economic, safe alternative is required.

In the waste classification system proposed by programs devoted to the development of near-surface disposal regulations, a class of waste that requires some sort of confinement greater than SLB was identified [MEZGA] .* of the three classes of wastes considered by NRC to be compatible with SLB, class $A$ wastes are acceptable for routine disposal in conventional SLB facilities wichout additional confinement. Class A wastes have low specific activity and include transuranic wastes having alpha contamination less than $10 \mathrm{nCi} / \mathrm{g}$. Clas $\mathrm{B}$ waste requires confinement in a stable matrix or waste form. Class $\mathrm{C}$ waste, also called "intruder waste," requires the use of at least $5 \mathrm{~m}$ of cover, or the use of engineered barriers, or packaging in highintegrity containers. In addition, the NRC has a category of waste not generally acceptable for SLB at depths less than 15 to $20 \mathrm{~m}$ [MEZGA]. This category, while considered by many to encompass only a small volume of waste, has come to be called GCD wastes. The NRC classification and disposal scheme identifies two broad categories of disposal: (1) near-surface disposal including conventional SLB (depths up to $20 \mathrm{~m}$ ) and greater depth disposal with at least $5 \mathrm{~m}$ of cover (depths of up to $15-20 \mathrm{~m}$ ) and/or the use of engineered barriers to reduce intruder potential and (2) disposal at depths greater than 15 or $20 \mathrm{~m}$. The DOE identifies burial at depths greater than conventional SLB (i.e., $20 \mathrm{~m}$ ) and the use of engineered barriers, containment, and solidification as options for achieving GCD [MEZGA]. Once the waste classification system has been completed, the DOE will be able to identify which technological options are the most appropriate for achieving GCD for specific wastes [MEZGA].

\section{b. Definition of GCD}

The DOE low"level waste management program has defined greater confinement as "the disposal of LLW in such a manner as to provide greater containment of radiation, reduced potential for migration/dispersion of radionuclides, and greater protection from inadvertent human and biological intrusions in order to protect the health and safety of the public [MEZGA]."

Greater confinement disposal is the emplacement of radioactive waste, with no expectation of retrieval, below grade level at sufficient depth that (1) surface effects (i.e., floods, Erosıon, etc.) on waste containment are minimized and (2) the consequence of any penetration of the waste by plant roots, burrowing animals, or normal use of the land by humans is within acceptable limits [CARD].

One study derived a recommended optimum depth for GCD. This optimum depth was about $35 \mathrm{~m}$ and assumed an arid site with an aquifer depth of

*Presumably those that will not fit into any of the classes of 10 CFR 61. 
$170 \mathrm{~m}$ [HUNTER]. Humid sites or sites with more shallow aquifers may be expected to have an optimum burial depth approximately midway between the aquifer and the surface.

\section{c. Comparison of the GCD and SLB Concepts}

From an operational point of view, GCD is quite similar to SLB. The GCD concept involves burying the waste within unconsolidated material near the surface, but at greater depth than practiced in SLB. The advantages and disadvantages of GCD as an alternative to SLB or deep geologic disposal are summarized below [CARD].

\section{Advantages:}

- GCD positions the waste farther from plant roots and animals than does SLB, minimizing the possibility of human intrusion (by definition, GCD is designed to minimize the inadvertent reclaimer scenario ${ }^{*}$ ).

- The increased depth may prevent, or reduce, infiltrating water from reaching the waste, thereby reducing the amount of waste that reaches the surface from upward migration.

- Stable temperatures at greater depths may be an important consideration where the formation of gases containing radionuclides is a concern.

- GCD provides greater protection against uncovering the waste through surface erosion.

- GCD, particularly at arid sites, may be a technically feasible and cost-effective alternative to deep geologic disposal for certain types of high specific activity wastes and wastes having long-lived nuclides, including transuranic wastes in very low concentrations.

\section{Disadvantages:}

- Increased costs are incurred for excavation and handling.

- The greater depth reduces the distance between the waste and the water table, increasing the potential for release to potable water supplies if water reaches the waste. This disadvantage, however, may not be significant, depending on the absorptive characteristics of the underlying strata, if the water table is sufficiently deep $(>100 \mathrm{~m})$.

\footnotetext{
* Presumably the radiation exposure of $\mathbf{z}$ person engaged in some future attempt to reciaim the site for purposes other than radioactive waste disposal.
} 
Other waste disposal considerations for GCD, such as transporting, stacking, and health and safety requirements, are similar to SLB considerations.

\section{d. DOE Program to Develop the GCD Concept}

After a preliminary screening of several alternatives to SLB, the option selected for further study was burial at greater depths (GCD), with or without some combination of solidification, containment, or engineered barriers [MEZGA]. Solidification, contaiment, and engineered barriers were included as aids to cunfinement because in some geological environments depth alone may not provide greater confinement than SLB [MEZGA].

The purpose of the DOE GCD program is to explore whether GCD disposal of LLW provides greater containment, reduces the potential for migra$t$ ion/dispersion of radionuclides, and provides greater protection for inadvertent human and biological intrusions in comparison with SLB [HUNTER]. The main goals of development of the GCD concept are [HUNTER]: (1) the environmental impact of GCD should not exceed that of SLB ani should conform to the guidelines of $10 \mathrm{CFR} 61$ and $10 \mathrm{CFR}$ 20, (2) the increased cost (presumably over that of SLB) should be justified by a cost/benefit index, defined as the product of the facility cost and the maximum individual dose in rem (after release of institutional control) divided by the inventory in total Curies placed into storage. A recent estimate [HUNTER] of this index, for typical sites in the arid West, gave a value of 1.73 for SLB and 0.31 for GCD, a reduction by a factor of nearly six.

Four sets of factors are considered important in the performance of a GCD facility and are to be investigated in the GCD program: (1) the geologic medium, including structural, thermal, mechanical and hydrologic properties, the transport of contaminants, and homogeneity; (2) the facility design, including emplacement depth, waste volume, dedicated land surface, backfill operation, monitoring system, and the waste canister; (3) facility operations, including the sequence of operations, waste-emplacement methods, waste handling and transfer methods, site maintenance requirements, and decommissioning requirements; and (4) waste characteristics, including leachability, radionuclide mobility, radioactivity inventory, thermal characteristics, packaging, and handling [HUNTER] .

\section{e. Plans for Demonstrating the GCD Concept}

Demonstration of one GCD concept at an arid site is being planned for the Nevada Test Site. The first objective 0 ' this demonstration is to evaluate the adequacy of geologic contairment of waste at below nearsurface depths. To accomplish this objective, three types of experiments have been defined: measurements of movement of moisture from the test hole, determination of the thermal response of the geologic medium to heatgenerating waste, and observations of nuclide migration. The second objective is to define equipmen" and procedures required for GCD operations. The third objective is to establish costs. The GCD demonstration will consist of six subtasks: (1) systems analysis and evaluation, (2) design, (3) construction, (4) operation, (5) monitoring, and (6) decommissioning. This demonstration 
was planned for FY 1982. The construction was planned for FY 1982-83, and operation is expected to be carried out duriag FY 1983-84 [MEZGA].

Demonstration of the intermediate-depth concept at a humid site is planned at Savannah River Laboratory [MEZGA], which plans to (1) operate a small-scale facility, (2) develop site-selection methods, (3) develop a reference design and uperaling procedures, and (4) monitor the behavior of the emplaced waste. Three initial designs have been suggested for an intermediate-depth facility at the SRL site: (1) a facility with a clay-lined bottom and a sloped clay cap--a layer of gravel would be positioned on the clay bottom from which any collected water would be periodically Fumped out, requiring preparations for long-term maintenance; (2) a facility with a clay cap but no clay bottom and no provisions for long-term maintenance; and (3) a facility consisting of deeply placed upright sections of concrete culvert that encloses the wastes [HOOKF, . The SRL is looking ahead to the possibility of introducing intermediate-depth waste burial when the need for additional LLW burial facilities arises. This need may be felt in 7-11 y. Preparations for this possibility will include site-selection work, the development of containment criteria, radionuclide-migration studies for selected facility designs, and the estimation of cost estimates [HOOKER].

\section{Criteria Proposed for GCD}

It is expected that criteria for GCD will be developed during 1983 [LEVIN-1982]. At this time, the only available indications of possible criteria for GCD are suggestions given in a report on proposed criteria [CARD], which are sumarized below. Only those criteria that seem likely to be of interest to organizations planning to send wastes to a GCD facility are of interest in the present study and are reported in some detail below. The criteria not discussed here include (1) radiation exposure protection to operating personnel, (2) radiation exposure protection for the general public, (3) documentation, (4) disposal-site waste handling, (5) inspection of waste received, (6) subsurface hydrology, (7) surface hydrology, (8) geology, (9) weather, (10) erosion, (11) tectonic activity, (12) archeological considerations, (13) recreational considerations, (14) natural resources, (15) flora and fauna impacts, (16) monitoring, (17) disposai depth, (18) buffer zone, (19) stratified disposal, (20) engineered barriers, (21) ownership, (22) demography, (23) land use, (24) resource commitment, (25) surface facilities, (26) personnel training, (27) occupational safety, (28) site security, (29) fire protection, (30) personnel and equipment decontamination, (31) equipment and facility maintenance, and (32) access roads.

The criteria and the associated suggested staniards that are 1 ikely to have a bearing on the plans of the organization intending to send its wastes to a GCD facility are summarized as follows.

Waste Description Criterion: Waste accepted for disposal shall be identified as to its source, physical characteristics, and general chemical makeup. 
Standard: The containers of all high-specific-activity or nonlow-specific-aitivity* waste crntaining long-lived isotopes shall be marked with a durable label describing the contained waste, the date it was packaged, the generator of the waste, and any identification number related to accompanying paperwork which describes associated hazards, radirnuclides, etc.

Waste Container Criterion: The waste container shall be adequate (1) to maintain its integrity during transportation, handling, and stacking at the disposal site, and (2) to permit decay of waste to levels that would not impose a public hazard if the container were breached at a reasonable period after disposal (i.e., $100 \mathrm{y}$ ). (The lifetime of the container may be less than $100 \mathrm{y}$ if the integrity of the waste disposal cell is designed to be maintained for $100 \mathrm{y.}$ )

Standard: A waste container shall be capable of supporting five times its own maximum loaded weight applied uniformly in the direction $i_{i 1}$ which it will normally be stacked. For certain types of waste (e.g., tritium), the containers should be designed to be capable of a reasonable period of integrity (e.g., 100 y) to permit decay to nonhazardous levels by the end of the control period.

Volume Refuction Criterion: The volume of the waste material shall be minimized, consistent with contemporary engineering and economic factors.

Standard: Reducible (by volume) or combustible waste shall be reduced in volume to the extent practical through the use of incinerators or compaction equipment.

solid.

Waste Form Criterion: The physical state of the waste shall be

Standard: Waste shall be in a dry solid form containing not more than $0.5 \%$ by volume or $3.8 \mathrm{~L}$ ( 1 gal) of free neutralized liquid per container, whichever is less. Liquids shall be immobilized by absorption in a dry, freestanding, homogeneous, monolithic matrix which is not readily dispersible, friable, or soluble.

Standard: Liquids may be accepted for disposal provided (1) there is no other practical means to immobilize or solidify the liquid, (2) specific DOE permission is granted, and (3) reasonable assurance can be given that the liquid will be completely contained in the disposal facility throughout the time the 1 iquid remains a radiologic hazard (e.g., reasonable assurance may be demonstrated by use of high-integrity containers).

Standard: The waste form shall not be liable to cause fires through friction, absorption of moisture, spontaneous chemical changes, or retained heat from manufacturing or processing, or when ignited, burn so vigorously and persistently as to create a hazard during handling, storage, and disposal operations.

Not quant itatively defined. 
Standard: The waste form shall not contain untreated oxidizing materia?s, including chlorates, permanganates, inorganic peroxides, nitrates, or any other material readily yielding oxygen in sufficient quancity to stimilate combustion.

Standard: Chemically reactive LLb for which there is no practicabie way to reduce the reactivity may be, subject to specific DOF. permission, accepted for GCD if isolated in boreholes. Reactive waste in boreholes ray be considered isolated if the depth of burial and borehole interspacing is greater than ten meters or greater than the distance required to absorb adequately the shock of detonation of twice the material without affecting nearby holes. Such materials may include waste which

- Is normally unstable and easily undergoes rapid chemical change without detonating; reacts rapidly with water or totus potentially explosive mixtures with water; generates or decomposes to form sufficient explosive or toxic gases, vapors, or fumes to be a hazard; or is a cyanide- or sulfidebearing waste which can generate toxic gases, vapors, or fumes when expoued to mild acidic or basic conditions.

- Is readily capable of detonation or of explosive deccmposition or reaction at normal temperatures and pressures, or reacts explosively with water.

- Is an explosive, i.e., any chemical conpound, mixture, or device which explodes with substantrally instantaneous release of gas and heat.

Waste Concentration Criterion: The average concentration of radioactive nuclides in the LLW disposed in a GCD facility at a generic arid site shall be low enough that releases to the biusphere will be within acceptable limits.

Standard: The concentrations of the airborne nuclides shall not exceed the limiting-case area concentration limits shown in column 2 of Table IV-3. The area concertration limit represents the amount or jnventory (Curies) of waste that can be disposed in a GCD facility per unit area (square meters) of site dedicated for disposal. The allowable concentration limits calculated for arid site conditions (expected case) are shown for the nuclides in column 3 of Table IV-3 for comparison. Where isotopic concentration limits are not listed, the concentrations of the isotopes are unrestricted, provided the radiation and thermal emissions of the waste package are within acceptable 1 imits. Nuclide-containing wastes having a concentration below that shown in column 4 of Table IV-3 should be considered for disposal at SLB sites.

Packaging for Transport on Public Road or Railways Criterion:

The waste package, including any overpack container or shielding, shall be capable of maintaining its integrity through any credible transportation accident.*

\footnotetext{
* This criterion would probably require the type of packaging classed as Type $B$ by DOT regulations in 49 CFR 171-179.
} 
Table IV-3. Proposed Area Cuncentration Disposal Limits for GCD of Airborne Wastes [HUNTER]a,b

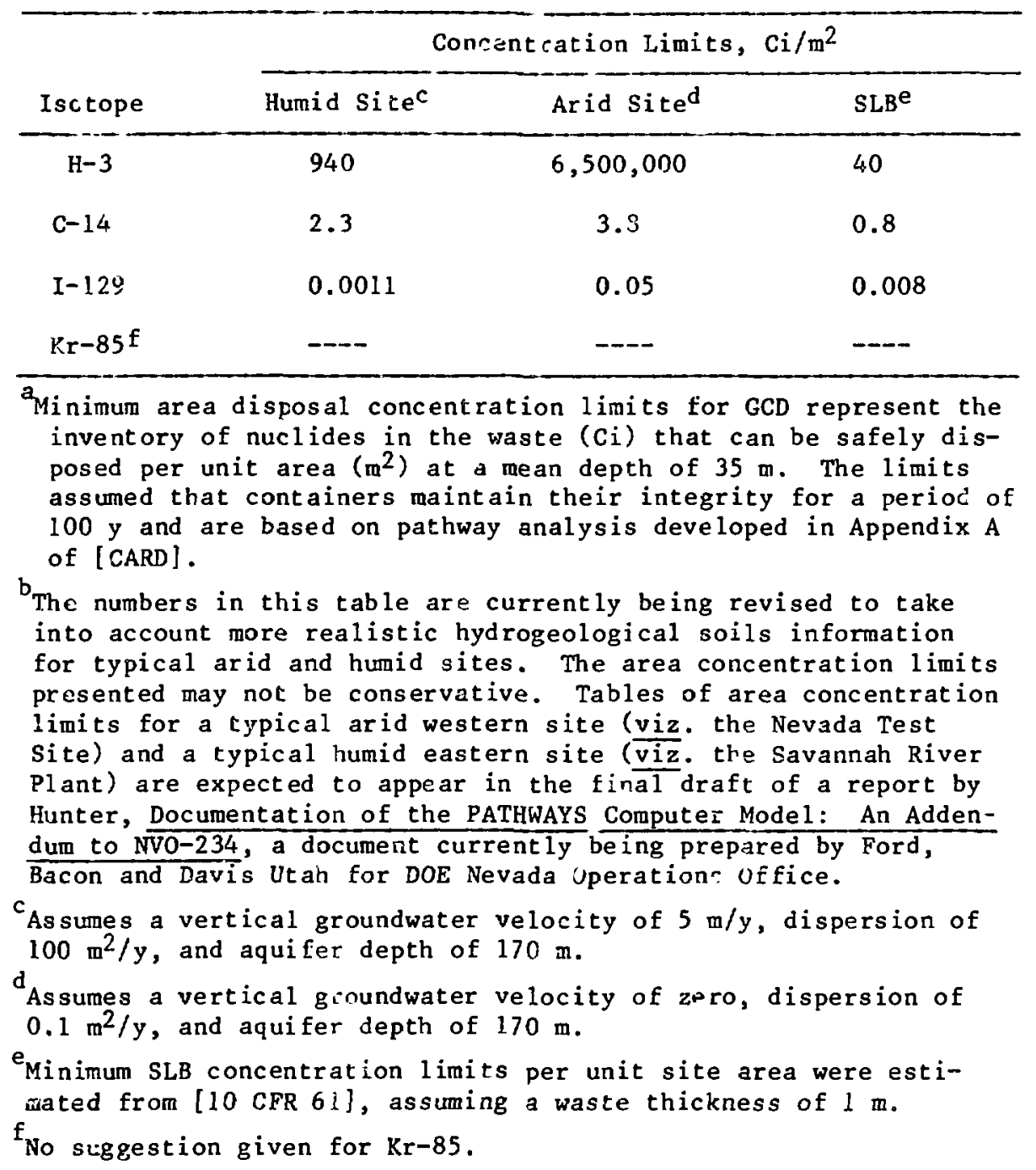

Standard: The waste container shall conform to the pertinent regulations of $\overparen{\mathrm{DOT}, \mathrm{NRC}}$, and any applicable laws of the state through which it may be transported.

Packaging for off-Loading and Stacking Criterion: Waste containars shall be designed with adequate strength to maintain their integrity during normal off-loading and stacking operations.

Standard: A11 packaged LLW ac :epted for disposal shall at a minimum meet the water spray, free drop, compresion, and penetration tests 
of [49 CFR 173.398] for Type A packages without a substanial reduction of the ef fectiveness of the package, loss or dispersal of the contents, or an increase in the maximum radiation levels recorded or calculated at the external surface of the package.

\section{Deep Geologic Disposal}

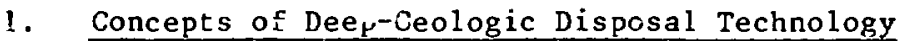

Several descriptions of deep-geologic disposal technology have been published over the past decade [ERUA-7j-43B, DOE/EIS-0046F-5.3, STEARNS, KAISER, BECHTEL]; this technology has evolved to the design stage [DOE/NWTS1 … Although several preliminary concepts for disposal of waste into deep geologic media have been proposed [BNWL, GHOVANLOU], the current national strategy is focused on pincing waste in metal canisters into cavities created by mining and drilling [DUE/NWTS-15].

A brief characterization of deep geologic disposal, suffizient for the present purpose, can be made in terms of three main aspects: the facility, handling operations, and packaging. A generic repository would have the following main characteristics [CRANDALL]: (1) sur face facilities capable of receiving and temporarily storing encapsulated nuclear waste, (2) shafts connecting the surface facilities with the underground storage horizon, (3) a storage horizon located underground in geologically stable strata, (4) a ventilation system providing fresh air underground and particulate filtration, (5) equipment to aid contact-handling * of TRU-contaminated LLW, and (6) specialized facilities and equipment to handle remotely HLW and ILW, including hot cells, casks, and shielded transporters.

Additional details of a repository created in a salt dome are suggested in [STEARNS]. Four types of waste are assumed to be accepted at such a facility: solidified HLW, solitified ILW, cladding hull waste (CHW), and TRU-contaminated LLW. These wastes are assumed to be delivered to the repository by truck or lailcar. The TRU-LLW would be emplaced at a depth of $460 \mathrm{~m}$ ( $1500 \mathrm{fr}$ ), and the HLW, ILW, and CHW would be emplaced at a depth of $610 \mathrm{~m}$ $(2000 \mathrm{fr})$. The HLW, ILW, and CHW are assumed to be delivered in steel canisters that would be placed in holes drilled in the host stratum. To facilitate retrieval, the holes could be fitted with carbon steel liners and concrete shielding plugs. The LLW incorporated into concrete is assumed to be received at the repository in the form of 55-gal drums that would be emplaced by using pallets and stacking operations.

The area occupien by a goneric repository includes an 80 -hertare, central, controlled area containing the surface facilitiss within a 240-hectare fenced area, with access roads and rail spurs. Workers at the surface facilities handle the incoming wastes and prepare them for transfer to the underground storage horizon. Surface operations include: (1) unloading of shipping casks and cargo carriers arriving by rail or truck, (2) transfer of waste packages to inspection stations, (3) decontamination of waste packages that: are

\footnotetext{
* Manual handling parmittea; does not require use of remote-handling apparatus.
} 
conıaminated upon arrival, (4) overpacking of contaminated waste packages as required, (5) transfer of waste packages to underground facilities, (6) radwaste treatment and handling of onsite-generated wastes, and (7) general repository support procedures.

Several buildings are necessary to -arry out the surface operations. (1) A receiving building houses all facilities and equipment to receive, handle, decontaminate, and temporarily store canisters requiring remote handling; both normal and overpacked canisters are prepared for transfer to underground storage. A separace wing of this building is used to receive LLW, packed in 55-gal drums and handled by direct-contact methods. (2) An undergroundoperations building houses (a) the support operations for underground facility personnel, their equipment, and supplies, (b) a maintenance and repair area for servicing all noncontaminated underground equipment, and (c) a warehouse with storage space for equipment and supplies. (3) A compressor-and-chiller building houses the compressors and water chillers for the air conditioning and ventilation systems, potable water, instrument air, compressed air, chilled water, and steam condensate systems. (4) A waste shaft-ventilation building contains the equipment to supply the shaft with conditioned air and houses the intake and exhaust air fans, filter, air conditioning, and electrical equipment. (5) A man-and-materials building houses equipment supplying ventilation to the man-and-material shaft, including fans, filters, air conditioning, and electrical equipment. (6) A ventilation-supply-filter building contains the filters for the conditioned ventilation air flowing to the underground areas. (7) A development-exhaust-filter building contains the filters for the exhaust air from the underground areas during mine development. (8) A repository3xhaust-filter building contains the filters for the ventilation exhaust air from the underground repository operating areas. (9) A radwaste building houses facilities, control room, and monitoring equipment processing the liquid and solid radioactive waste generated on site. All waste generated on site is expected to be LLW. After treatment and encapsulation, the drums are conveyed to the LLW area of the receiving building in preparation for lowering to the underground repository area. (10) An administration building houses all activities necessary to the administration of the site. (11) Storage of the media excavated from the mine may require storage in a structure at the surface for protection from weather elements.

The generic repository has five shafts: (1) waste-handling shaft, (2) man-and-material handling shaft, (3) ventilation-supply shaft, (4) repository-operations ventilation exhaust shaft, and (5) the mine-development ventilation exhaust shaft. Each shaft extends some distance below the storage horizon and is lined with concrete from the surface to about $30 \mathrm{~m}$ into the storage horizon.

The layout of underground areas is based on the following design considerations. (1) All shafts are located in a central area. (2) The underground development area is 800 hectares. (3) The waste is always emplaced in the outermost available areas of the repository. (4) The repository is initially excevated to permit one year of operation before waste emplacement operations are started. (5) The salt pillar between the storage rooms is sized to provide an adequate heat sink. For the generic repository, these pillara 
are $42 \mathrm{~m}$ wide to eccomodate the maximum design heat load of $370 \mathrm{~kW} / \mathrm{hertare}$. The pillars also maintain the physical integrity of the storage rooms. (6) During operation of the facility, continuous mining is carried out to open new slorage roons while waste is emplaced in the existing rooms. (7) High heat-producing wastes (HLW and spent fuel) must be retrievable after the start of operations, for a period of time to be determined by criteria and regulation developments. (8) The ILW and LLW are emplaced without provision for retrievability.

During initial development, five main corridors accommodate mined salt conveyors, mining equipment, fork-lift trucks, personnel, and air supply and exhaust flow while mining operations are in progress. Support facilities for mining operations are located in the central area. This support area includes personnel accommodations, shops, tool room, storage areas, and maintenance areas. Excavated salt is hoisted to the surface fcr stockpiling. No backfilling is scheduled during the retrievability period. ${ }^{*}$ Other concefts [ARBITAL], however, call for backfilling immediately following emplacement with an easily removed media, e.g., washed sand. The mine is laid out with the storage ronms connected at right angles to branch corridors and separated by salt pillars. These rooms may be entered from branch corridors at either end. Main corridors extend in two directions from the central core area and afford access to each branch corridor. The main and branch corridors are about $9 \mathrm{~m}$ wide and $4.5 \mathrm{~m} \mathrm{high}$, and each storage room is about $6 \mathrm{~m}$ wide, 4.5 to $7.5 \mathrm{~m} \mathrm{high}$, and $300 \mathrm{~m}$ long. The height of the room takes into account the movement of the ceiling and floor from salt creep thermally induced by HLW.

Several wells are drilled in each room for storing waste that must be handled remotely. The placement of the storage wells varies with the heat load or sizes of the waste-handling equipment, depending on the type of waste stored. After a retrievability period, the storage room is backfilled with salt from ongoing mining operations or from the surface salt stockpile.

Ventilation is separately provided to the waste storage area and to the continuing mining operation. The ventilation air flow is arranged so that air is always moving towards areas of potentially higher contamination. The air pressure through the mining area is greater than that in the storage area so that flow is always away from mining personnel and toward the waste storage areas.

The specifications for packaging that will be accepted for deep geological disposal have yet to be fixed in the development of criteria, regulations, and design. Preliminary packaging concepts, however, have been described, and preliminary criteria for acceptance of packages at a deep geological repository have been suggested [RHO-CD-568]. It has been assumed that spent fuel and HLW would arrive in specially designed canisters and that ILW and TRU-contaminated LLW would arrive in 55-gal drums. Proposed canister characteristics are sumarized in Table IV-4. Proposed acceptance criteria are summarized by the data of Table IV- 5 .

* time period to be set by disposal regulations, following emplacement of waste, during which the retrieval of wastes in containers is permitted. 
Tabie IV-4. Proposed Waste Canister Characteristics [ARBITAL]

\begin{tabular}{|c|c|c|c|c|c|c|}
\hline \multirow[b]{3}{*}{ Char acter ist ic } & \multicolumn{4}{|c|}{ Conmercial waste } & \multirow{2}{*}{\multicolumn{2}{|c|}{ Defense High-Level Waste }} \\
\hline & \multicolumn{2}{|c|}{ Srenc Fuel } & \multicolumn{2}{|l|}{ HLW } & & \\
\hline & EIS $^{a}$ & Kaiser ${ }^{\mathrm{b}}$ & EIS ${ }^{a}$ & $\begin{array}{l}\text { Stearns- } \\
\text { Roger }^{c}\end{array}$ & \multicolumn{2}{|c|}{ Hanfordd $\quad$ SRpe } \\
\hline Waste Fort & $\begin{array}{l}1 \text { PHR fuel } \\
\text { assembly or } \\
1 \text { BWR fuel } \\
\text { aBsembly }\end{array}$ & $\begin{array}{l}1 \text { PWh fue! } \\
\text { assembly or } \\
2 \text { BWR fuel } \\
\text { assemblies }\end{array}$ & $\begin{array}{l}\text { Glass or } \\
\text { Calcine }\end{array}$ & G1 ass & $\begin{array}{l}\text { Glass or } \\
\text { Calcine }\end{array}$ & $\begin{array}{l}\text { Glass or } \\
\text { Calcine }\end{array}$ \\
\hline Canister Shape & Cylinder & Cylinder & Cylinder & Cylinder & Cyl inder & Syl inder \\
\hline Canister Material & $\begin{array}{l}\text { Stainless or } \\
\text { Carbon steel }\end{array}$ & Carbon Steel & $\begin{array}{l}\text { Stainlegs or } \\
\text { Carbon Steel }\end{array}$ & $\begin{array}{l}\text { Stainless } \\
\text { Steel }\end{array}$ & Carbon stcel & Carbon Steel \\
\hline \multicolumn{7}{|l|}{$\begin{array}{l}\text { Canister Dimensions } \\
\text { and Weight }\end{array}$} \\
\hline Outside Diameter, in. & $\begin{array}{l}14 \text { (PWRR) } \\
10-3 / 4 \text { (BWR.) }\end{array}$ & $14-1 / 2$ & $\begin{array}{l}12-3 / 4(\text { glase }) \\
8-5 / 8 \text { (calcine) }\end{array}$ & $12-3 / 4$ & 24 & 24 \\
\hline Length, ft & $\begin{array}{l}16 \text { (PHR) } \\
16 \text { (BWR) }\end{array}$ & $15-1 / 2$ & $\begin{array}{l}10 \text { (glass) } \\
10 \text { (calcine) }\end{array}$ & 10 & 12 & 10 \\
\hline Weight, lb & $\begin{array}{l}2380(\mathrm{PWR}) \\
1360(\mathrm{BWR})\end{array}$ & 3500 & $\begin{array}{l}1720(\mathrm{glass}) \\
720(\mathrm{calcine})\end{array}$ & 23500 & $\begin{array}{l}24800 \text { (glass) } \\
23200 \text { (calcine) }\end{array}$ & $\begin{array}{l}\text { ¿5000 (glass) } \\
\text { v]500 (calcine) }\end{array}$ \\
\hline Overpack Haterial & $\begin{array}{l}\text { Stcinless or } \\
\text { Carbon Steel }\end{array}$ & Carbon Steel & $\begin{array}{l}\text { Stainless or } \\
\text { Carbon Steel }\end{array}$ & Carbon Steel & $\mathrm{NS}^{\mathrm{f}}$ & Stainleos Steel \\
\hline \multicolumn{7}{|l|}{$\begin{array}{l}\text { Overpack Dimensions } \\
\text { and Weight }\end{array}$} \\
\hline Outside Dimeter, in. & $\begin{array}{l}16 \text { (PWR) } \\
12-3 / 4(B W R)\end{array}$ & 16 & $\begin{array}{l}14 \text { (glasa) } \\
10-3 / 4 \text { (calcine) }\end{array}$ & 14 & NS & 27 \\
\hline Length, ft & $\begin{array}{l}16-1 / 2(\mathrm{PWR}) \\
16-1 / 2(\mathrm{omin})\end{array}$ & Variable & $\begin{array}{l}11 \quad(g 1 a g \theta) \\
11 \text { (calcine) }\end{array}$ & $10-1 / 3$ & NS & $10-5 / 16$ \\
\hline $\begin{array}{l}\text { Weight (Canister + } \\
\text { Overpack), 1b }\end{array}$ & $\begin{array}{l}3120(\mathrm{PWR}) \\
1950(\mathrm{BWR})\end{array}$ & Variable & $\begin{array}{l}2150 \text { (glass) } \\
990 \text { (calcine) }\end{array}$ & $\pi 4000$ & NS & $\begin{array}{l}5500(\text { glass }) \\
2000 \text { (calcine) }\end{array}$ \\
\hline Canister Fill & $\begin{array}{l}\text { Helium } \\
\text { (5 psig) }\end{array}$ & Sand & $\begin{array}{l}\text { Helium } \\
\text { (5 psig) }\end{array}$ & $A \mathrm{i}=$ & Air & Air \\
\hline $\begin{array}{l}\text { Canister Heat Generation } \\
\text { Rate, kw/Canister }\end{array}$ & $\begin{array}{l}0.55 \text { (PWR) } \\
0.18 \text { (BWR) }\end{array}$ & $\begin{array}{l}1.75(\mathrm{PHR})^{\mathrm{f}} \\
1.12(\mathrm{BWR})\end{array}$ & $\begin{array}{l}2.8(\mathrm{glass}) \\
2.5(\mathrm{calcine})\end{array}$ & 4.35 & 0.26 & $\begin{array}{l}0.34 \quad(\mathrm{~g} 1 \mathrm{ass}) \\
0.21 \text { (calcine) }\end{array}$ \\
\hline $\begin{array}{l}\text { Canister Radionuclide } \\
\text { Content, Ci/Canister }\end{array}$ & $\begin{array}{l}1.9 \times 10^{5}(\mathrm{PWR}) \\
6.2 \times 10^{4}(\mathrm{BWR}) \\
\end{array}$ & $3.9 \times 10^{5}(\mathrm{PWR})$ & $\begin{array}{l}6.7 \times 10^{5}(\text { (glass) } \\
1.3 \times 10^{5} \text { (calcine) }\end{array}$ & $8.0 \times 10^{5}$ & $\begin{array}{l}4.3 \times 10^{3}(\mathrm{~g} 1 \mathrm{ag} \theta) \\
7.5 \times 10^{3} \text { (calcine) }\end{array}$ & $\begin{array}{l}5.9 \times 10^{4} \quad(\mathrm{glass}) \\
3.7 \times 10^{4} \quad(\text { colcine }) \\
\end{array}$ \\
\hline 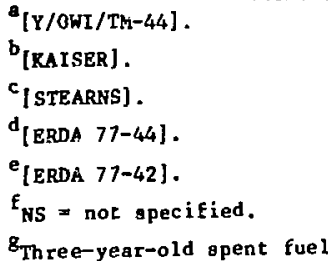 & & & & & & \\
\hline
\end{tabular}


Table IV-5. Proposed Canister Acceptance Criteria

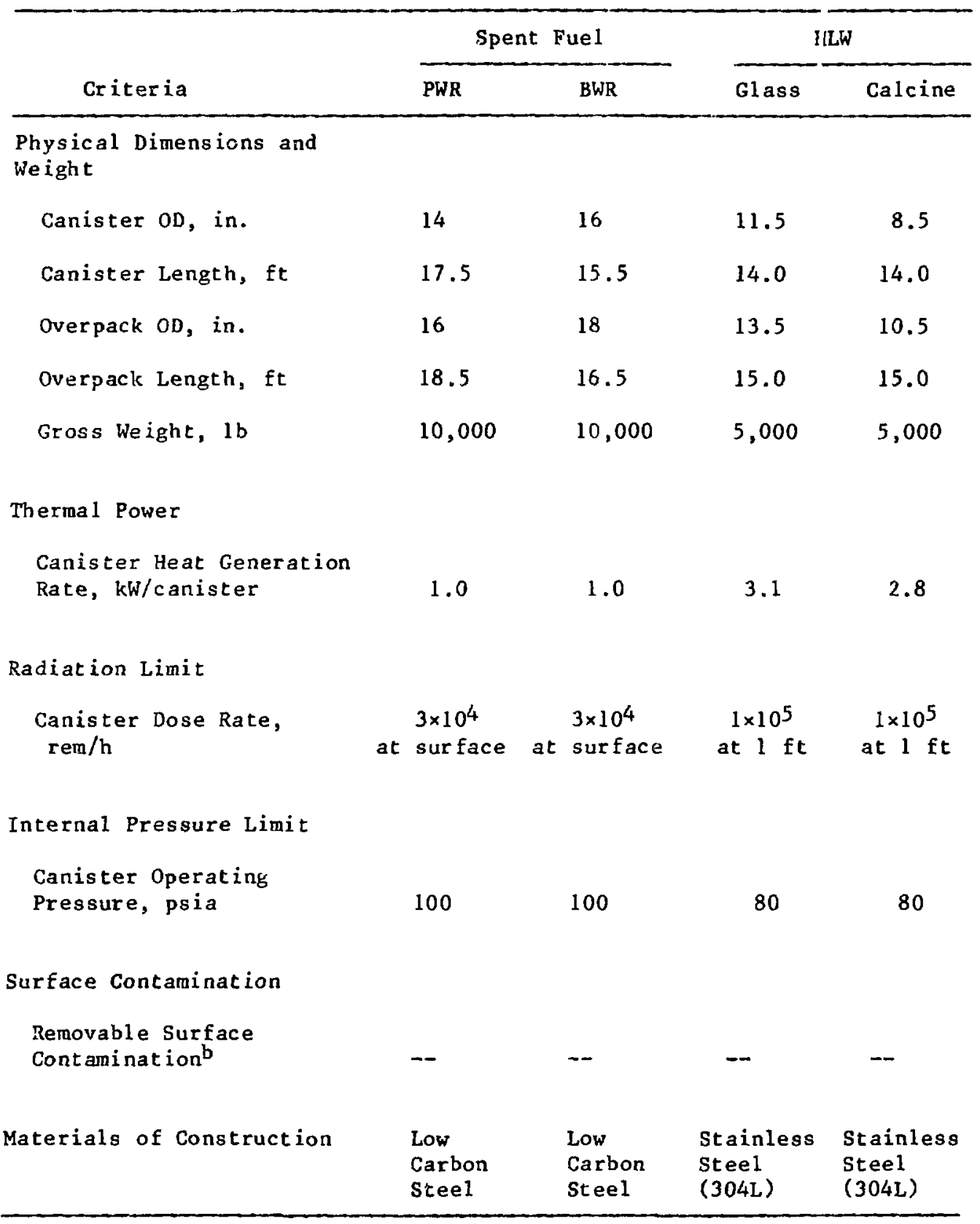

a [ARBITAL], abstracted from [RHO-CD-568].

${ }^{b}$ see $[49$ CFR 173.397]. 
The packaging concepts have varied in several conceptual studies done for the NWTS project through the Office of Nuclear Waste Isolation (ONWI). A study by the Bechtal National Corp. [CRANDALL] contains suggestions on construction of packaging to be received at a deep geological repository. In particular, this study assumed that a mixture of off-gases--krypton, carbon dioxide, and xenon--would be stored as compressed gas in cylinders at the repository. This off-gas storage, however, would seum not to conform to the proposals on materials acceptable for geologic disposal that are in 40 CFR 191. These packaging concepts are summarized in the following paragraphs and in Table IV-6.

The HLW is put into a canister fabricated from carbon steel pipes ( $32.4 \mathrm{~cm}$ OD by $3 \mathrm{~m}$ long, with a wall thickness of $0.95 \mathrm{~cm}$ ). A carbon steel pipe ( $3.4 \mathrm{~m}$ long, $35.6 \mathrm{~cm}$ OD) encases the canister as the overpack. Each canister contains approximately $0.18 \mathrm{~m}^{3}$ of vicrified waste and generates $22 \mathrm{~kW}$ of heat one year after discharge from the reactor. At ten years after discharge from the reactor, the heat generarion rate is about $2.6 \mathrm{~kW} / \mathrm{canister}$.

Hulls, end fittings, nr failed equipment are contained in a canister fabricated from carbon steel pipe $30-\mathrm{cm}$ dia, $1-\mathrm{cm}$ wall thickness, $3-\mathrm{m}$ long). An overpack capability is provided is case the canister is damaged before it is stored in the repository. The overpack is also fabr:cated from carbon steel pipe (56-cm dia, $1-\mathrm{cm}$ wall thickness, $3.3-\mathrm{m}$ long).

The end-fittings canisters are identical to the hulls canisters and hold the severed end fittings of either three PWR or six BWR assemblies. The overpack is a carbon steel container identical to the hulls canister overpack.

Failed equipment, which is disassembled and reduced in size at the facility, is also packaged in hulls canisters.

The TRU wastes are sealed in 55-gal carbon steel drums (DOT $17 \mathrm{C}$ or 17H). Depending on the corrosive character of the waste, some of the drums may require plastic 1 iners or stainless steel construction with 83-gal carbon steel drum overpacks.

The compressed gas cylinders used for the containment of krypton, xenon, and carbon dioxide have a nominal volume of $50 \mathrm{~L}$. They are made from $23-\mathrm{cm}$ ( 9 in.) dia pipe and are $1.40 \mathrm{~m}$ long. The cylinders are modified by the installation of a special valve designed for high-temperature service. The radioactivity of the gas-filled cylinders is (considered to be the equivalent of) high level. Groups of six gas cylinders are encapsulated in a $56-\mathrm{cm}$ (22-in.) OD carbon steel canister.

\section{Criteria and Regulations for Deep Geologic Disposal}

Two definitions are presented to aid the interpretation of criteria and regulations for deep geologic disposal. "High-Level Radioactive Waste" (HLW) means (1) irradiated reactor fuel, (2) liquid wastes resulting from the operation of the first-cycle solvent extraction system (or equivalent) and the concentrated wastes from subsequent extraction cycles (or equivalent) in a 
Table IV-6. Conceptual Packaging Characteristics for Deep-Geologic Disposal [CRANDALL]

\begin{tabular}{|c|c|c|c|c|c|}
\hline $\begin{array}{l}\text { Content and } \\
\text { Type of Package }\end{array}$ & $\begin{array}{l}\text { Package } \\
\text { OD by length, } \\
\text { m }\end{array}$ & $\begin{array}{l}\text { Gross } \\
\text { Weight, } \\
\text { kg }\end{array}$ & $\begin{array}{l}\text { Decay } \\
\text { Heat, } \\
\mathrm{kW}\end{array}$ & $\begin{array}{l}\text { Overpack } \\
\text { OD by length, } \\
\text { m }\end{array}$ & Remarks \\
\hline $\begin{array}{l}\text { Vitrified HLW } \\
\text { canister }\end{array}$ & $0.30 \times 3.05$ & 780 & 2.60 & $0.35 \times 3.30$ & $80 \%$ fill \\
\hline Hulls canister & $0.51 \times 2.05$ & 1,905 & 0.46 & $0.56 \times 3.30$ & \\
\hline End fittings canister & $0.51 \times 3.05$ & 590 & 0.10 & $0.56 \times 3.30$ & \\
\hline $\mathrm{Kr}-\mathrm{Xe}-\mathrm{CO}_{2}$ canister & $0.56 \times 3.05$ & - & - & - & $\begin{array}{l}6 \text { gas cylinders } \\
\text { per canister }\end{array}$ \\
\hline \multicolumn{6}{|l|}{ ILW Canister } \\
\hline $\begin{array}{l}\text { TRU and non-TRU } \\
\text { wastes }\end{array}$ & $0.51 \times 3.05$ & 1,497 & - & $0.56 \times 3.30$ & \\
\hline Failed equipment & $0.51 \times 3.05$ & - & - & $0.56 \times 3.30$ & \\
\hline LLW (TRU) drum & (55 gal) & 381 & - & $(83 \mathrm{gal})$ & \\
\hline
\end{tabular}


facility for reprocessing irradiated reactor fuel, and (3) solids into which such liquid wastes have been converted. "Geologic Repository" means a system which is intended to be used for the disposal of radioactive wastes in excavated geologic formations. A geologic repository includes (1) the geologic repository operations area and (2) all surface and sub-surface areas where natural events or activities of man may change the extent to which radioac'ive wastes are effectively isolated from the biosphere.

Wastes addressed in [10 CFR 60] and [DOE 5820] are HLW, as defined above, and the disposal area addressed is a deep-geologic facilicy as described in Section IV.C.1. The major features of the proposed rule cover performance objectives, siting requirements, design and construction (of the repository), waste packaging, and performance confirmation.

The code 10 CFR 60 (for HLW) is not as specific as 10 CFR 61 (for LLW), possibly because further development of 10 CFR 60 by the NRC must await issuance by the EPA of final standards for disposal of HLW. The "engineered system" comprises two major barriers--the waste package and the underground facility--each with its own performance objectives. In addition, independent requirements are for containment, controlled release rate, and 1,000-y groundwater transit time.

The specified technical criteria which appear to be most relevant to our study are given in Table IV-7.

The waste-form and waste-package requirements, addressed in 10 CFR 60.135, must be weighed relative to the proposed waste forms for the airborne wastes under evaluation in this program. The effects of the site on the waste package, the waste package on the site, and the waste form on the waste package inust also be evaluated sr. that the given items are not compromised. Some design considerations are: solubility, oxidation/reduction reactions, corrosion, hydriding, gas generation, thermal effects, mechanical strength, mechanical stress, radionuclide retardation, radiolysis, radiation damage, leaching, fire and explosion hazards, thermal loads, and synergistic interactions.

The waste-form requirements are: a solid, all particulates to be in a consolidated form, any combustibles converted to a noncombustible form, nonexplosive, nonpyrophoric, not chemically reactive, and no free liquids in an amount to impair waste integrity.

The waste package design requirements are that the container maintains waste containment during transportation, emplacement and retrieval, is handle$a b l e$, and has a unique identification. The final version of 10 CFR 60 was recently published.

The DOE has initiated a "National Waste Terminal Storage (NWTS) Program," which is aimed at development of genlogical dicnosal; criteria for such disposal are described in [DOE/NWTS-33(1)], which discusses program objectives, and performance criteria; in [DOE/NWTS-33(2)], which presents site performance criteria; in [DOE/NWTS-33(3)], which presents repository performance criteria; and in [DOE/NWTS-33(4)], which presents wast.e package performance criteria. 
Table IV-7. Technical Criteria for Deep Geologir Disposal [10 CFR 60]

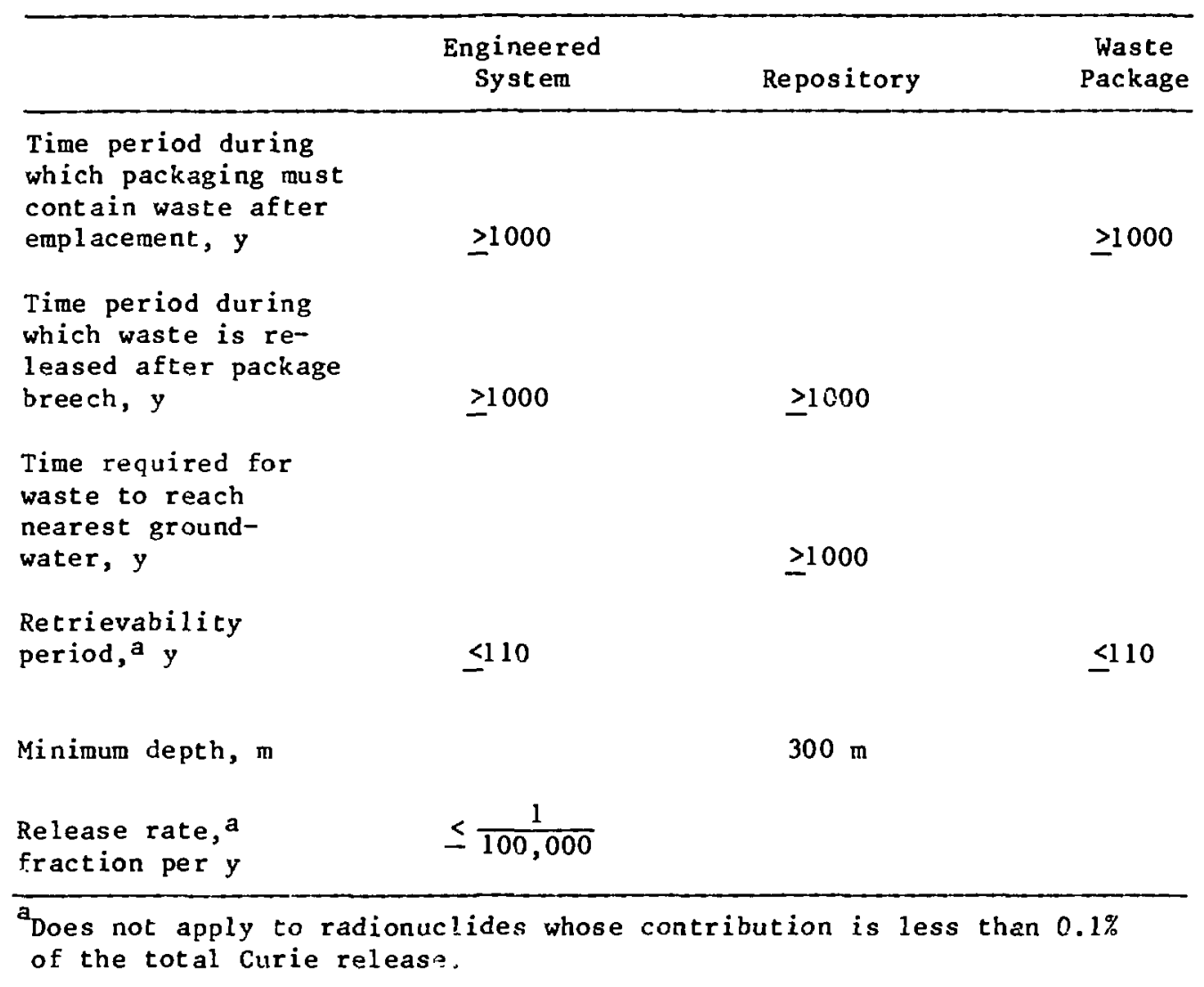

Performance specifications have been proposed for the waste form [DOE/NWTS-19] and the waste package [DOE/NWTS-20]. These are to be followed by more-detailed specifications. Interim specification for the Defense HighLevel Waste form for geologic disposal is proposed in [N/DFT-35]. A second set of documents is being generated covering wastes sent to the WIPP for disposal of TRU wastes [WIPP-DOE-114; WIPP-DOE-069 (Rev 1); DOE 5820 (draft)].

Information from some of the above criteria, requirements, and product specifications in response to proposed and existing regulatory requirements has been collated. This information is presented for the overall general disposal and site requirements in Table IV-8, for the waste form in Table IV-9, and for the waste package in Table IV-10. The bulk of the available information on contractor response to regulations is in the area of defense TRU waste, with little or no information for commercial TRU or HLW.

Based on review of the information in the tables, a sumitry of some of the required physical, chemical, thermal, and mechanical properties of the 
Table IV-8. Criteria and Characteristics of Deep-Geologic Isolation

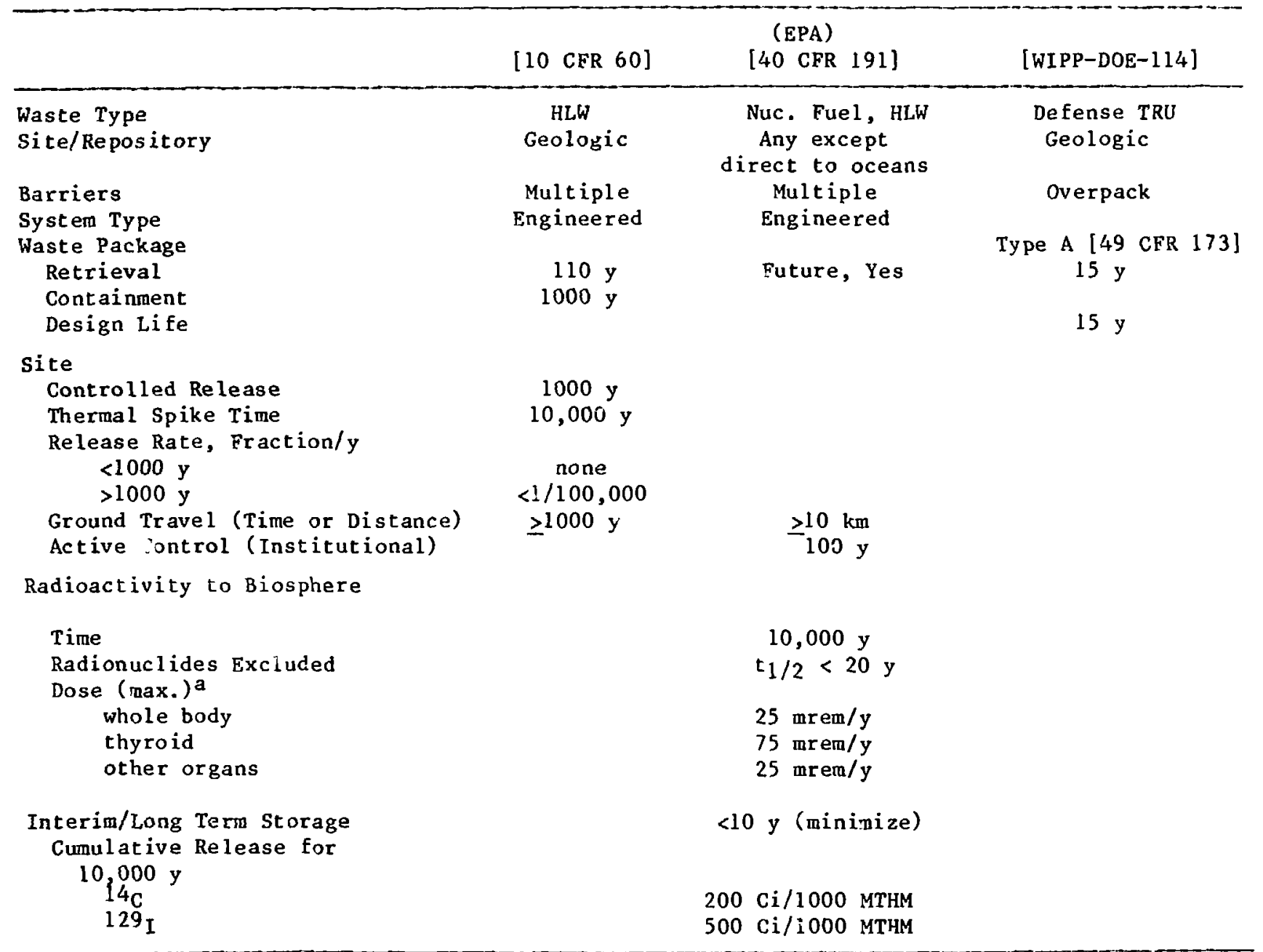

a These limits apply only to management and storage. 
Table J.V-9. Waste Form Requirements for Deep-Geologic Disposal

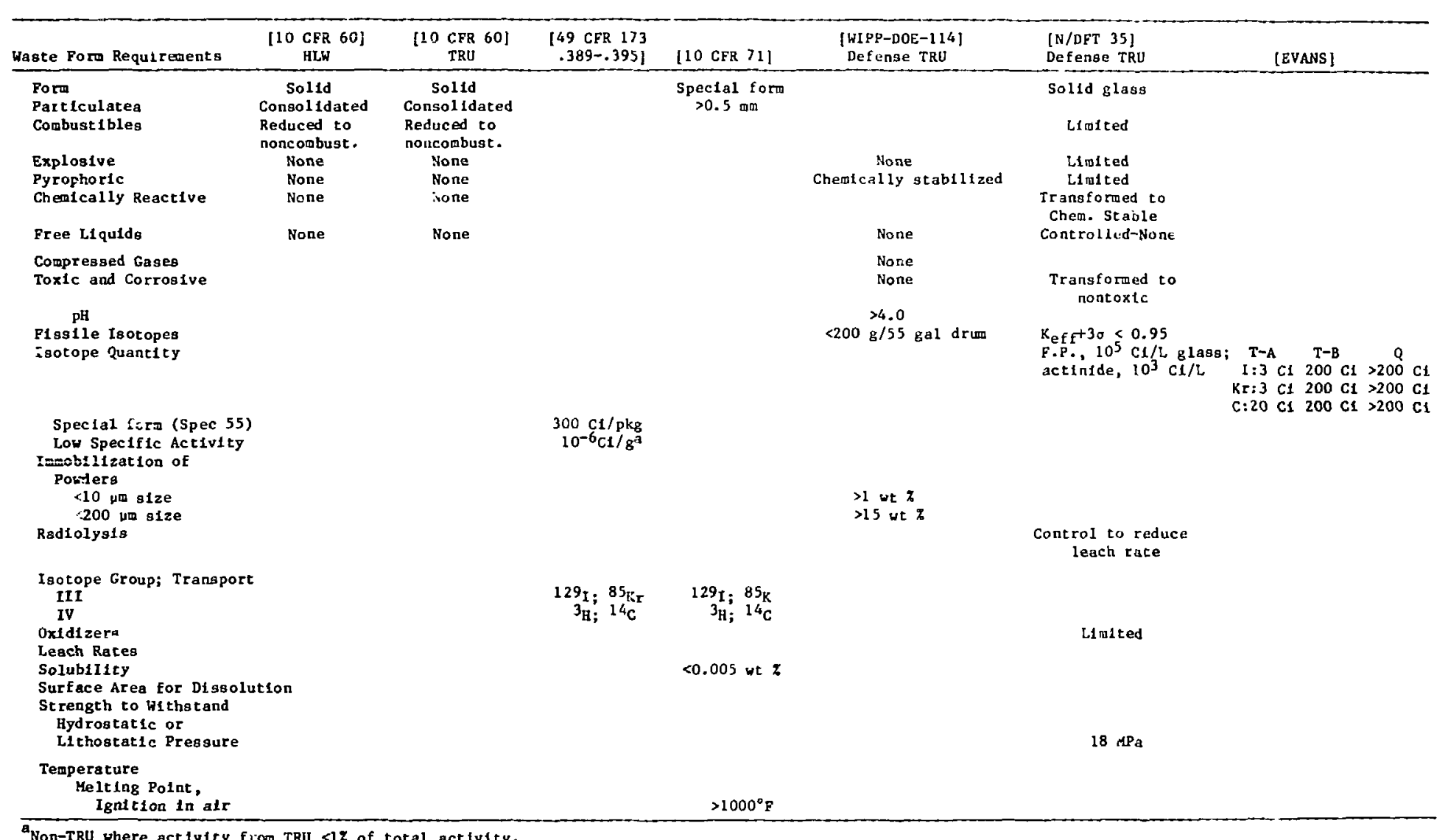


Table IV-10. Waste Package Requirements for Deep-Geologic Disposal

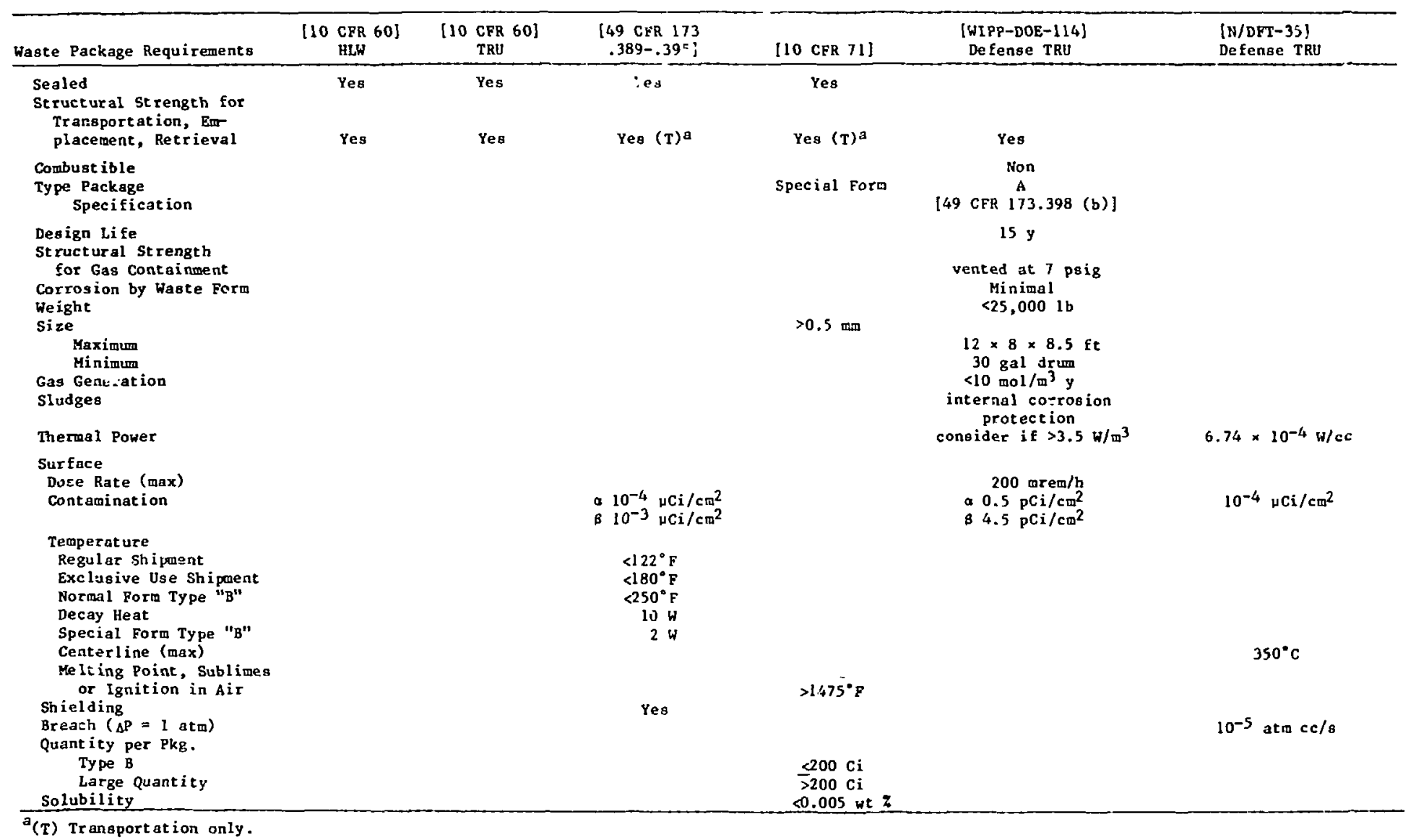


site, waste form, and waste package can be generated (Table IV-11). Our sole interest here is in the properties that might be applicatle to the waste forms and containers associated with the airborne wastes under consideration.

D. Ocean Disposa1

\section{Practices in Ocean Disposal of LLW}

\section{a. Present Status}

Opinions on the propriety of using the ocean for nuclear waste disposal have been set forth by private environmental groups. The present study, however, is 1 imited to a consideration of the expected performance of tie disposal technologies and comparison of this performance to Federal regulations and criteria; therefore, this section of the report does not treat nonregulatory discussions and opinions.

Much of the information presented in this section has been obtained from the recent review by Holcomb on the history and practice of ocean disposal of LLW [HOLCOMB]. Ocean disposal of high-level wastes is prohibited at present. The ocean disposal of low-level wastes, although not present $1 y$ practiced by the U.S., was not legally prohibited until the U.S. House of Representatives recently passed legislation establishing a two-year moratorium on EPA approval of applications for ocean disposal of LLW [NWN]. Amendments to the Marine Protection, Ressarch, and Sanctuaries Act would allow EPA to consider permit applications following expiration of the moratorium, dependent on an impact assessment to be filed by the applicant. The assessment will be required to include a list of radioactive materials, number of Curies, exposure levels, in rems, at the exterior and interior of the container, and an analysis of environmental impact. Osean dumping of LLW will continue to be attractive to countries whose geography and geology nake shallow-land burial difficult. Several aspects of ocean dumping of LLW that should be considered in the question of applicability to disposal of airborne wastes are presented here. Probably the two most important considerations of ocean disposal, for the analysis to be done here, are regulations and acceptable packaging.

\section{b. History of the Practice of Ocean Dumping of LLW}

Several countries, including the U.S., practiced ocean dumping of radioactive materials during the years 1946-1972 without any international control. Beginning in the summer of 1967 , several countries dumped LLW in the Northeast At lantic under the supervision of the NEA. From 1967 to 1980, about $700,000 \mathrm{Ci}$ of radioactivity, contained in materials weighing about 70,000 tons, were dumped in this area. Between 1946 and 1970 , the U.S. dumped LLW at 50 locations in the Atlantic, che Pacific, and the Gulf of Mexico. These actions involved a total of 86,000 containers and a total of 94,500 Ci. These U.S. dumping activities were carried out under AEC authority by AEC contractors.

Since ocean dumping of low-level wastes was practiced for several years, it is considered that the technology has been amply demonstrated. 
Table IV-11. Summary of Information That May Be Required on Wastes Destined for Geologic Disposa1a

Waste Form

Container

Physical Properties

$\begin{array}{lc}\text { Dimensions } & X \\ \text { Geometry } & x \\ \text { Weight } & X\end{array}$

Density

$\mathrm{x}$

Structural

Support

Particle size Distribution

$\mathbf{X}$

Anount of

Particles

$x$

Impact Resistance

\section{$\mathrm{X}$}

Surface Area for Leaching

$\mathrm{X}$

$\mathbf{x}$

Chemical Properties

Leach Rate

X

Volatility

$\mathrm{X}$

Fl ammability

$\mathrm{X}$

$\mathrm{X}$

Flash Point

$\mathrm{X}$

Isotope Content

$\mathrm{X}$

Chemical

Composition

$\mathrm{x}$

Chemical Forms

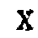

Phases

$\mathrm{X}$

Radiolysis

$\mathbf{X}$

Activity Level

$\mathrm{X}$

${ }^{a}$ pooled from documents on criteria and proposed regulations 1 isted in Tabies IV-8 through IV- 10 . 
Table IV-1] (Cont'd)

\begin{tabular}{|c|c|c|}
\hline Item & Waste Form & Container \\
\hline \multicolumn{3}{|c|}{ Mechanical Properties } \\
\hline Tensile Strength & $\mathrm{x}$ & $\mathrm{x}$ \\
\hline $\begin{array}{c}\text { Compressive } \\
\text { Strength }\end{array}$ & $x$ & $x$ \\
\hline Shear Stress & $x$ & $x$ \\
\hline $\begin{array}{l}\text { Mociulus of } \\
\text { Elasticity }\end{array}$ & $\mathrm{x}$ & $\mathrm{x}$ \\
\hline Sthear Modulus & $\mathrm{x}$ & $\mathrm{x}$ \\
\hline Bulk Modulus & $\mathrm{x}$ & $\mathrm{x}$ \\
\hline Elongation & $\mathrm{x}$ & $\mathrm{x}$ \\
\hline Charpy Impact & $\mathrm{x}$ & $\mathrm{x}$ \\
\hline Thermal Properties & & \\
\hline $\begin{array}{l}\text { Thermal Con- } \\
\text { ductivity }\end{array}$ & $\mathrm{x}$ & $\mathrm{x}$ \\
\hline Specific Heat & $\mathrm{x}$ & $\mathrm{x}$ \\
\hline $\begin{array}{l}\text { Coefficiont of } \\
\text { Thermal Ex- } \\
\text { pansica }\end{array}$ & $x$ & $\mathrm{x}$ \\
\hline Melting Point & $\mathrm{x}$ & $x$ \\
\hline $\begin{array}{l}\text { Temperat ure } \\
\text { Limits }\end{array}$ & $x$ & $\mathrm{x}$ \\
\hline
\end{tabular}

\section{Criteria and Regulations for Ocean Disposal of LLW}

\section{a. Philosophy}

Accorfing to Holcomb two philosophies characterize the use of ocean dumping: dilution/dispersal and containment [HOLCOMB]. The current U.S. position favors containmen.. Revisions in 1979 on the policy of the NEA of the $\mathrm{OECD}$ recommend minimizing release to the sea.

The tone of IAEA recommendations is that, although it has produced, specifically for ocean dumping, definitions of waste classes and recommendations for their handling, this effort should not be construed as encouragement for ocean dumping. Current general expectations are that ocean dumping would be used only if it is shown to be the best alternative to other disposal possibilities. 


\section{b. History of Rules on Ocean Dumping of LLW}

The regulations and laws related to LLW ocean dumping differ from those for all other modes of disposal in that multilateral, international agreements rather than U.S. laws only must be considered. The EPA has the authority to control the use of this method of disposal by U.S. Organizations and is charged with the responsibility of ensuring compliance of U.S. activities with international agreements.

In the 1958 Conference on the Law of the Sea, the IAEA initiated moves to control dumping. During the 1960 s, the NEA developed operational controls for the safe dumping of LLW. The London Convention on the Prevention of Marine Pollution by Dumping of Wastes and Other Matter, commonly referred to as the London Ocean Dumping Convention (LODC), was assembled in 1972. It produced a treaty, accepted by 43 countries including the U.S., that became effective in 1975 .

The LODC gave the IAEA responsibility for defining high-level waste, i.e., waste not acceptable for dumping, and for making recommendations on disposal of other waste types. In 1973-1975, the IAEA issued initial recommendations but further wcrk was required. The IAEA recornendations were based on estimated dose rates derived from information on seafood consumption, oceanography, and marine biology. In 1975-1977, the IAEA revised these recommendations, and the revisions have been effective since 1978.

\section{c. Content of Rules on Ocean Dumping of LLW}

Unde: the LODC, each member nation is required to establish national control over materials leaving its shores for dumping. The LODC rules include operational controls that address conditioning and fackaging of waste, choice of a dumping sile, and container design. Not only a number of prohibited substances (Annex I) but also a list of substances requiring special permits (Annex II) are 1 isted by the LODC treaty.

Although the main interest in this methed has been for disposal of LLW, international guidelines also al low the dumping, in limited concentra$t$ ions, of alpha-radioactive wastes and also wastes that might normally be considered medium or intermediate-level radioactive materials.

In 1978, the IAEA produced a generic assessment of radiological consequences with the object of defining HLW unsuitable for ocean dumping. The basis for these definitions was the long- and short-term transport of radionuclides in the ocean, considering physical transport processes and possible pathways to man. The aciivity limits were based on dose limits established by the International Comission on Radiological Protection. The result is the definition of three classes of wastes and specific activity limits for each above which any waste would be considered unsuitable for dumping. The limits for specific activities of waste for ocean dumping are: for alpha emitters, $1 \mathrm{Ci} / \mathrm{MT}$; for beta-gamma emitters with $t_{1 / 2}>0.5$ y (except tritium), $10^{2} \mathrm{Ci} / \mathrm{MT}$; and for tritium and beta-gamma emitters with $t_{1 / 2}<0.5 \mathrm{y}, 10^{6} \mathrm{Gi} / \mathrm{MT}$. 


\section{d. Administration of Rules}

The LODC is administered by the Intergovernmental Maritime Consultative Organization (IMCO). Al though the LODC authorized individual countries to supervise dumping operations, most OECD member countries favored cont inuing NEA surveillance. Therefore, NEA agreed to cont inue a supervisory role and issued a statement of consultation and surveillance that was adopted in 1977 by the OECD Council. The OECD role is consistent with the objectives and principles of the LODC and the IAEA. The important aspects are:

(1) establish and update standards, guidelines, and recommendations,

(2) provide consultation,

(3) provide international surveillance,

(4) report to the $O E C D$,

(5) assess site suitability,

(6) monitor previous dumping sites, and

(7) provide notification of proposed disposal actions.

The U.S. is committed to application of the LODC to protect the marine environment and, as a participant in NEA-OECD agreements, to cooperate in surveillance of ocean disposal. The U.S. commitments to the LODC are enforced by Public Law 92-532, the Marine Protection Research and Sanctuaries Act of 1972. This law also gives EPA the authority to regulate ocean dumping of LLW by permit. With this authority, the EPA issued initial regulations and criteria in 1973. These rules stated the philosophy that U.S. objectives would be remote containment, not dilution/dispersal. Final regulations were issued in 1977, reiterating the philosophy that properties of packaging should permit desay to innocuous levels within the expected lifetime of the container or matrix. Since assuming this authority, the EPA has issued no permits for ocean dumping of radioactive materials.

\section{e. Posicion of the U.S. on Ocean Dumping of LLW}

Ocean dumping by the U.S. was discontinued for two main reasons. (1) The AEC and the nuclear industry decided to use shallow land burial; among other reasons, it was less costly [LEVIN-1982]. (2) According to [HOLCOMB], the Council on Environnental Quality issued a report to the President recommending the prohibition of ocean disposal for HLW and any other radioactive material unless no other alternative offered less risk to man and the environment.

Aftar accepting the authority to regulate ocean dumping, the EPA began a program to determine the status of ocean sites in which dumping had been done. Between 1974 and 1978, the EPA conducted surveys on the condi$t$ ion of waste containers in both Atlantic and Pacific disposal sites. The EPA surveys of the Pacific sites in 1974, 1975, and 1976 were done from samples of 
sediment, water, biological materials, and photos. The EPA also recovered a crum for corrosion observations. Some drums were observed to have imploded and low concentrations of radioactivity were found near some containers. It was concluded, however, that no risk to man or marine environment had been incurred.

Additional EPA surveys off the coasts of Maryland and Delaware found Cs-137 in sediment near drume, but also concluded that no risks to man or environment were involved. Some containers, retrieved from ocean disposal sites, were examined by BNL for corrosion, leaching, and degradation. Although the containers were corroded to varying degrees, the concrete matrix inside them had not degraded appreciably in 15 years of seabed residence [HOLCOMB]. Regardless of these favorable observations, the U.S. is presently neither encouraging nor discouraging ocean dumping, except for the present moratorium; if ocean dumping vere allowed, its use would be strictly regulated

\section{f. Packaging for Ocean Disposal of LLW}

Since criteria for ocean disposal of LLW emphasize containment, packaging must have certain general attributes. The proper choice of corrosion-resistant materials and cuatings for containers is expected to delay release to the ocean, permitting additional radioactive decay before exposure of waste or matrix to the ocean. Several factors could retard the release of packaged wastes to the ocean: radioactive decay: packaging integrity lasting several years; designs that include multiple barriers of bitumen, metal, plastic or concrete; slow leaching; and sorption by bottom sediments.

Packaging has commonly consisted of 55-gal drums or cylindrical vessels cast of concrete. Within these containers, the wastes are commonly incorporated into a matrix of concrete or bitumen. In some cases, pressureequalization devices have been incorporated into the design. The low-level wastes have included a wide range of physical and chenical forms that can be incorporated into matrices. Although many matrix materials have been used to incorporate LLW, e.g., plaster of Paris, urea formaldehyde, bitumen, and organic polymers, cement is the matrix that has been used most in ocean disposal.

Guidelines for ocean disposal of packages of radioactive waste were prepared by NEA in 1974 [HOLCOMB]. The NEA convened another group in 1978 to review and revise these 1974 guidelines, setting forth general requirements for packaging design, radiological safety considerations, and instructions for packaging manufacture and assembly.

In 1979 the IAEA convened a group to assess requirements and practices of packaging radwaste for ocean disposal. The resulting report recommended IAEA guidance on licensing, operations, and administration [HOLCOMB]. Recommendations on packaging by IAEA are compatible with those of NEA guidelines on that subject. The major points are: 
(1) Waste should be cast in or absorbed in a matrix.

(2) Liquids must be carried on an absorbent material in a primary container, which must be enclosed in a secondary container. The space between the containers must also be filled with absorbent.

(3) Packages must provide containment during handling, transport, and descent to the bottom.

(4) Specific gravity of packages must be $>1.2$ to promote descent to the bottom and resistance to movement in currents.

(5) Package design must ensure that the inner container remains on the sea floor.

(6) The container must remain intact under sea pressure or be equipped with a pressure-equalization device.

(7) Buoyant materials must be excluded or be treated to prevent return to the surface or be innocuous and non-interfering in legitimate uses of the sea if they do return to the surface.

\section{Concepts for Ocean Disposal of HLW}

Disposal of HLW below the seabed has been identified, although presently prohibited, as an alternative to geologic repositories [ONWI-65]. Final EPA standards and NRC operating criteria are not yet available for subseabed disposal [SAND80-2384]; therefore, it was assumed by the Subseabed Disposal Program (SDP) that standards for subseabed would be the same as those for HLW in mined (geologic) repositories. The EPA is "... in the process of reviewing existing rules governing the ocean disposal of hazardous materials including radioactive waste. These were put into effect in 1977, as required under the Marine Protection and Sanctuaries Act passed in 1972" [RADEX]. Present policy appears to be that "disposal of high-level waste, defined in the 1977 regulations .... is absolutely prohibited" [RADEX].

The concept of emplacing I-129 wastes at a depth of about $30 \mathrm{~m}$ into ocean sediments has been under evaluation at Sandia [KLETT-1982]. This concept is not explored here because the regulations against which this practice could be compared have not been formulated.

\section{E. Packaging}

1. Current Federal Requirements on Packaging for Transportation of Radioactive Materials

\section{a. Responsibilities of Federal Agencies}

The responsibilities of Federal agencies in regulation of packaging of radioactive materials for transportation are summarized in Table IV-12. Since it is unlikely that airborne wastes from the nuclear fuel cycle 
Table IV-12. Agency Responsibilities in Packaging of Radioactive Materials for Transportation

\begin{tabular}{|c|c|c|}
\hline Agency & $\begin{array}{l}\text { Area of } \\
\text { Responsibility }\end{array}$ & Regulations \\
\hline DOT & $\begin{array}{l}\text { All radioactive materials in } \\
\text { Interstate Commerce }\end{array}$ & Parts of 49 CFR $171-179$ \\
\hline NRC & $\begin{array}{l}\text { Radioactive materials of the } \\
\text { nuclear fuel cycle }\end{array}$ & 10 CFR 71 \\
\hline FAA & $\begin{array}{l}\text { Transportation of radioactive } \\
\text { materials by air }\end{array}$ & 14 CFR 103 \\
\hline USCG & $\begin{array}{l}\text { Transportation of radioactive } \\
\text { materials by water }\end{array}$ & 46 CFR 146,149 \\
\hline USPO & $\begin{array}{l}\text { Transportation of limited quantities } \\
\text { of radioactive materials by mail }\end{array}$ & 39 CFR $123-125$ \\
\hline $\mathrm{DOE}$ & $\begin{array}{l}\text { Transportation of radioactive } \\
\text { materials by Headquarters divisions, } \\
\text { offices, field organizations, and } \\
\text { contractors }\end{array}$ & DOE 5480.1 , Chap III \\
\hline
\end{tabular}

will be shipped by air or water, or through the mail, the regulations of the FAA, USCG, and USPO will be ignored here. Therefore, this discussion will deal with the regulations of DOT and NRC only. Since transportation is likely to be by exclusive-use shipment, regulations applying to common carriers are ignored.

The latest revision of DOT rules for transportation of radioactive wastes was issued recently [FEDREG 10218]. Revision of NRC rules on the same topic is expected to be issued also. The consistency of NRC and DOT regulations has been expressed in memoranda of understanding. The DOT regulations likely to have the most significance for waste management planning [49 CFR 173.389-173.398] are reviewed below.

The following discussion is a summary of the elements of DOT regulations that would be likely to apply to considerations of shipping the airborne wastes. The intent is to illustrate how the information in 49 CFR would be used to select packaging for these nuclides that would permit their transportation in compliance with the regulations. Although the regulations contain directions on a number of procedures to be followed, such as labeling of packages, placarding of vehicles, routing of shipments, controlling of surface contamination, and controlling of external radiation levels, probably the most important consideration for the present task is use of the regulations to extract an indication of what packaging would be permitted for the airborne wastes. 


\section{b. Determination of Acceptable Packaging}

Several classification schemes are to be found in DOT regulations. The characioristics of the radioactive material to be shipoed place it in a category or categories in these schemes. The categories, in turn, determine what packaging would be acceptable for the given material.

This indication of permissible packaging is probably one of the most important rcles that transport regulations play in decision making for handling any radioactive waste.

Perhaps, the best place to begin in determining acceptable packaging for $\mathrm{H}-3, \mathrm{I}-129, \mathrm{C}-14$, and $\mathrm{Kr}-85$ is the question of whether the material will qualify as special form.

Special form material, because of the properties of either the waste form or its container, is essentially nondispersible in water, in a fire, and under severe impact conditions. The complete definition is found in $49 \mathrm{CFR}$ 173.403. A practical significance of the special form definitions is that the rules permit a larger quantity of radioactive material in special form to be shipped in some packages because of the greatly reduced dispersibility. It is unlikely, however, that any of the airborne waste forms will qualify as special form material. Furthermore, it is unlikely that, for economy, airborne waste forms will be carried in containers that would qualify as special form. Therefore, it is assumed that the airborne waste forms would be classified as normal form according to DOT regulations. Accordingly, no further discussion on special form material is included here, and in the compliarice analysis concerning transportation, properties of airborne waste forrus and their packagings will be considered in the light of rules for normal form materials only.

A second point in choice of packaging is the $A_{2}$ value assigned to the nuclide by regulations. Each of the airborne nuclides is assigned a value of $A_{1}$ and $A_{2}$, which $p l$ ay a role in determining acceptable packaging. (The assigned values of $A_{1}$ and $A_{2}$ represent the maximum number of Curies permitted in Type A packages in special form and normal form, respectively.) For the present task, only the $A_{2}$ value, relevant to materials in normal form, is considered. The $A_{2}$ values for the airborne nuclides are listed in Table IV-13.

A third point to be considered in the choice of packaging is whether the material to be shipped is exempt from specification packaging and labeling rules because of its small quantity or concentration. Two categories may qualify for exemption: limited quantity and low specific activity. The limited-quantity category is $10^{-3}$ A2 per package for gases other than tritium and solids. It is unlikely that any of the airborne waste forms would be economically managed in such small quantities. The low-specific-activity category is a concentration of $3 \times 10^{-4} \mathrm{Ci} / \mathrm{g}$ for the airborne nuclides, because their $A_{2}$ values are $>1 \mathrm{Ci}$. Low-specific-activity material can be transported in DOT specification 7A, Type A packaging, or in any other strong, tight packaging that meets several other requirements listed in 49 CFR 173.425 . 
Table IV-13. Assignment of $A_{2}$ Values to the Airborne Nuclides by DOT Regulations [49 CFR 173.435]

\begin{tabular}{lr}
\hline \multicolumn{1}{c}{ Nuclide } & $\mathrm{A}_{2}, \mathrm{Ci}$ \\
\hline $\mathrm{H}-3$ (uncompressed) & 1000 \\
$\mathrm{H}-3$ (compressed) & 1000 \\
$\mathrm{H}-3$ (activated luminous paint) & 1000 \\
$\mathrm{H}-3$ (adsorbed on solid carrier) & 1000 \\
$\mathrm{H}-3$ (tritiated water) & 1000 \\
$\mathrm{H}-3$ (other forms) & 20 \\
$\mathrm{I}-129$ & 2 \\
$\mathrm{C}-14$ & 60 \\
$\mathrm{Kr}-85$ (uncompressed) & 1000 \\
Kr-85(compressed) & 5 \\
\hline
\end{tabular}

If the material to be transoorted is not exempt from specification packaging, then the next point to be considered is whether the amount of nuclide per package is less than or greater than $A_{2}$. If the quantity is not greater than $A_{2}$, Type A packaging $c a n$ be used, or Type $B$ packaging may be used if desired. If the quantity is greater than $A_{2}$, then Type $B$ packaging must be used.

The regulations divide Type $B$ packaging into two sub-categories: $B(U)$, which requires unilateral approval in international shipments, and $B(M)$, which requires multilateral approval in international shipments. Since the present task considers only shipments of girbcrne wastes within the U.S., all Type B packagings are applicable.

In the choice of packagings, four general options seem to be available: (1) use of DOT specification packaging, (2) use of an NRC-1icensed packaging that is already licensed specifically for the waste form of interest, (3) adaptation of an NRC-1icensed packaging that has been licensed for some other cargo, and (4) design of a new packaging.

Table IV-14 1 ists the packagings that are permitted for carrying the radioactive material at $\leq A_{2}$ and $>A_{2}$. Six specification packagings are listed in Table IV-14: $7 \mathrm{~A}, \overline{6 M}, 20 \mathrm{WC}, 2 \mathrm{R}, 6 \mathrm{~L}$, and $6 \mathrm{~J}$. A brief description of these packagings is given in Table IV-15. Specification 20WC packaging is pictured in Fig. IV-1; Spec. 6M packaging, including the Spec. $2 R$ container, is pictured in Fig. IV-2; Spec. 6J is illustrated in Fig. IV-3; and Spec. 6L is illustrated in Fig. IV-4. 
Table IV-14. Dor-Authorized Packaging and Corresponding Quantitiesa

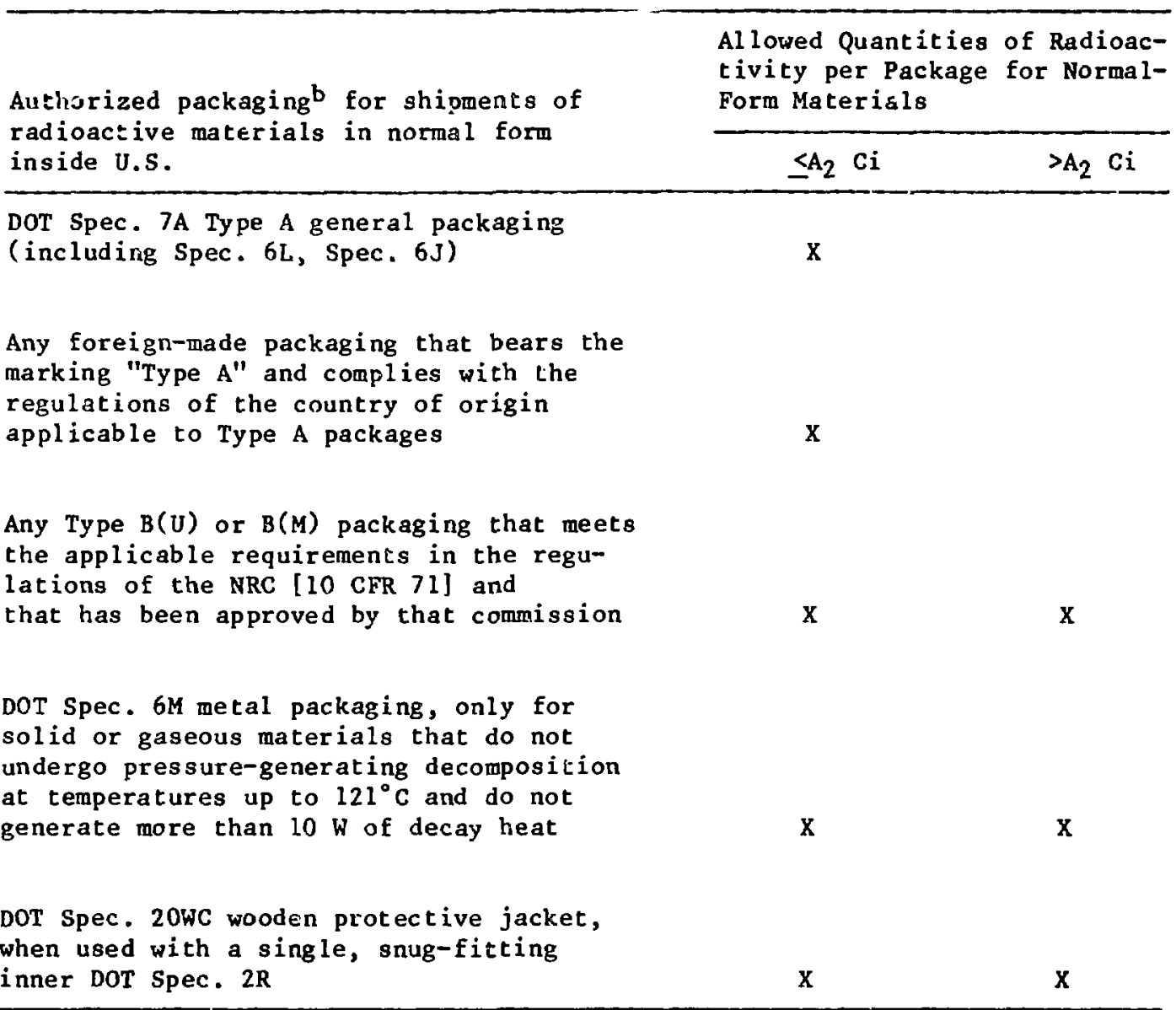

${ }^{2}$ Derived from DOT rules revised March 10, 1983 [FEDREG 10218].

${ }^{b}$ All packagings employing Spec. 55 containers are onitted here. Since only existing Spec. 55 containers can be used (the construction of new ones was prohibited after December 31, 1975), it is unlikely that they would be used in shipments of any airborne waste forms from fuel reprocessing operations. 
Table IV-15. Description of Specification Packaging

\begin{tabular}{|c|c|c|}
\hline Specification & 49 CFR Part & Description Summary \\
\hline 20WC & 178.194 & $\begin{array}{l}\text { A family of overpacks, } 20 \text { WC-1 through } \\
20 \text { - } 6 \text {, with permissible carrying } \\
\text { capacity ranging from } 500 \text { to } 6000 \mathrm{lb} \text {, } \\
\text { depending on construction. General } \\
\text { configuration is a cylindrical shell } \\
\text { constructed by stacking rings of plywood } \\
\text { or hardwood glued together and reinforced } \\
\text { with steel rods, threaded at the ends and } \\
\text { secured with washers and nuts. Some of } \\
\text { the members of this family must be en- } \\
\text { cased in steel liners. (See Fig. IV-1.) }\end{array}$ \\
\hline $2 \mathbf{R}$ & 178.34 & $\begin{array}{l}\text { Inner contalner of metal; cylindrical } \\
\text { configuration closed by screw-cap, } \\
\text { welding, brazing, or flanged cover. } \\
\text { Maximum I.D. of } 30 \mathrm{~cm} \text {, maximum length of } \\
183 \mathrm{~cm} \text { (Examples of use are in } 6 \mathrm{M} \text { and } \\
6 \mathrm{~L} \text { packaging; see F1gs. IV-2 and }-4 . \text { ) }\end{array}$ \\
\hline $6 \mathrm{M}$ & 178.104 & $\begin{array}{l}\text { Steel drum outer of } 10-110 \text { gal capacity. } \\
\text { Inner container of no less than } 1.24 \mathrm{~L} \\
\text { capacity. Inner container conforms to } \\
\text { Spec. } 2 \mathrm{R} \text { with maximum I.D. of } 13.3 \mathrm{~cm} \\
\text { and is fixed within the drum by solid } \\
\text { centering media. Permissible gross } \\
\text { welght, varying with volume, up to } 640 \mathrm{lb} \\
\text { for } 110-\text { gal drum. (See F1g. IV-2). }\end{array}$ \\
\hline $7 A$ & 178.350 & $\begin{array}{l}\text { A general specification that requires } \\
\text { conformance to (1) the general require- } \\
\text { ments that all packaglngs must meet as } \\
\text { described in } 49 \text { CFR } 173.24 \text {, (2) the stan- } \\
\text { dards for Type A packaging in } 49 \text { CFR } \\
173.389 \text { (j) and } 173.398 \text { (b), and (3) pack- } \\
\text { age markings in accord with } 49 \text { CFR } \\
178.350-3 \text {. }\end{array}$ \\
\hline $6 \mathrm{~J}$ & 178.100 & $\begin{array}{l}\text { Drum with rolling hoops of low-carbon } \\
\text { steel with maximum capacity of } 55 \text { gal } \\
\text { and maximum gross weight of } 8801 \mathrm{~b} \\
\text { (See Fig. IV-3.) }\end{array}$ \\
\hline $6 \mathrm{~L}$ & 178.103 & $\begin{array}{l}\text { Outer drum of low carbon steel, with } \\
\text { hoops rolled or swaged, with capacity of } \\
55 \text { to } 110 \text { gal and inner vessel of not } \\
\text { more than } 17.74 \text { L capactty. Maximum } \\
\text { welght limits are } 350 \text { lb for } 55 \mathrm{gal} \text { size } \\
\text { and } 480 \mathrm{lb} \text { for } 110 \mathrm{gal} \text { size. } \\
\text { (See Fig. IV-4.) }\end{array}$ \\
\hline
\end{tabular}




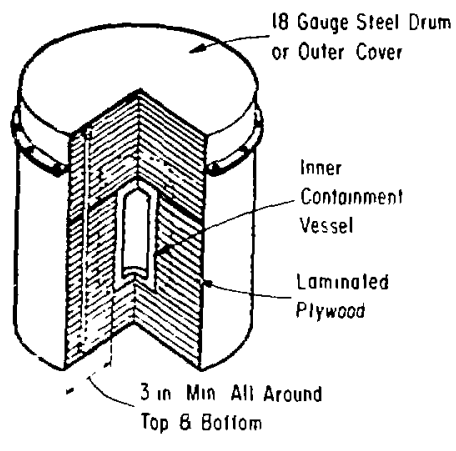

(a) Spec. 20wc-2

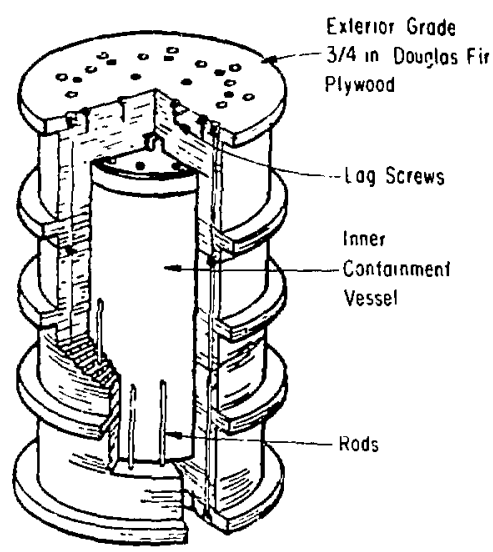

(b) Spec. 20wc-5

Fig. IV-1. DOT Specification 20WC Packaging [49 CFR 178.194-7].

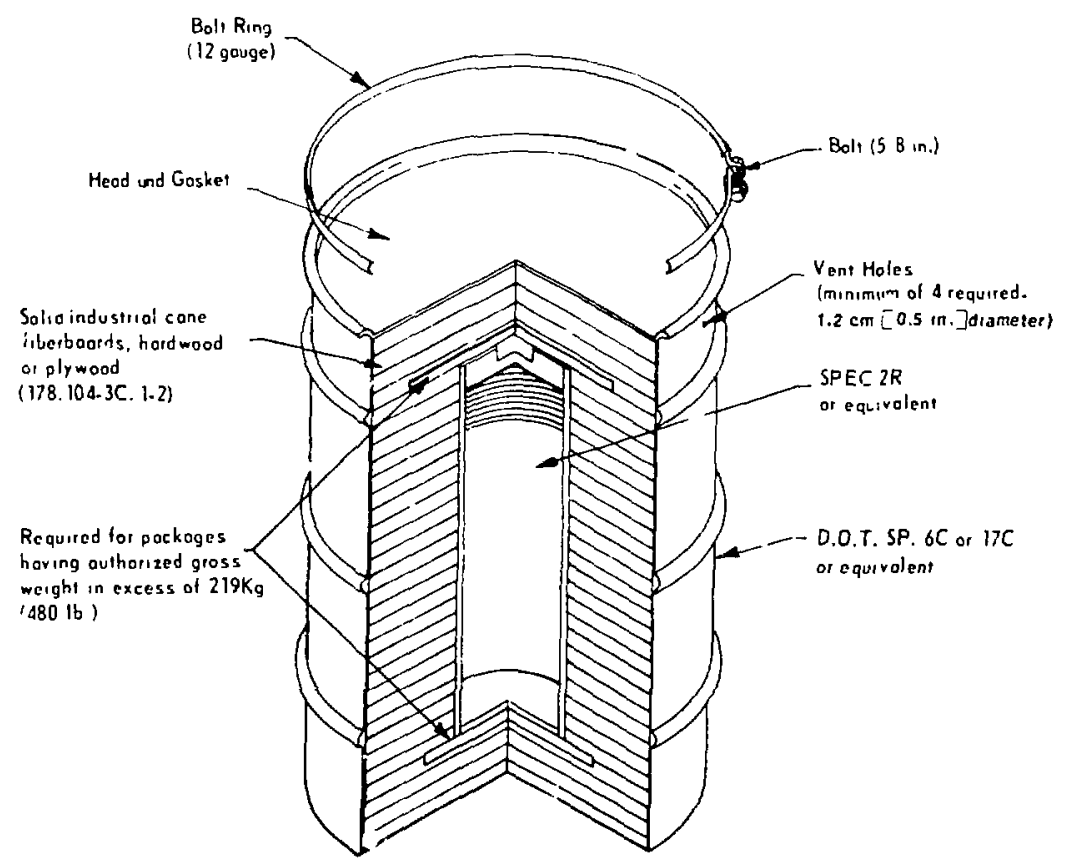

Fig. IV-2. DOT Specification 6M Packaging Including Spec 2R Inner Container [EDLING]. 


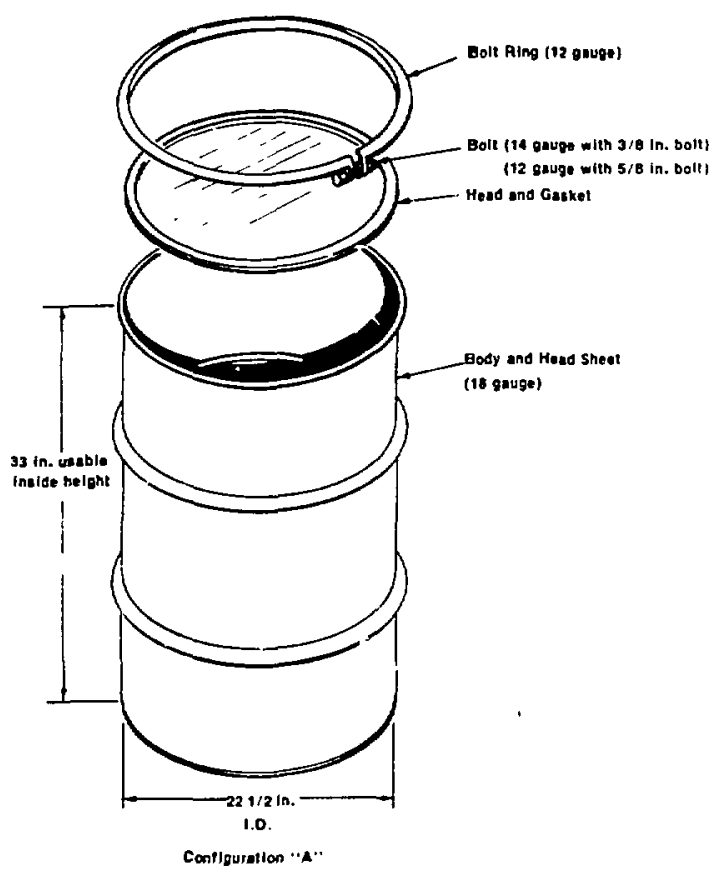

Fig. IV-3.

DOT Specification 6J

Packaging, Configura-

tion A [EDLING].

Fig. IV-4.

DOT Specification 6L

Packaging Including

Spec $2 \mathrm{R}$ Inner Container [EDLING].

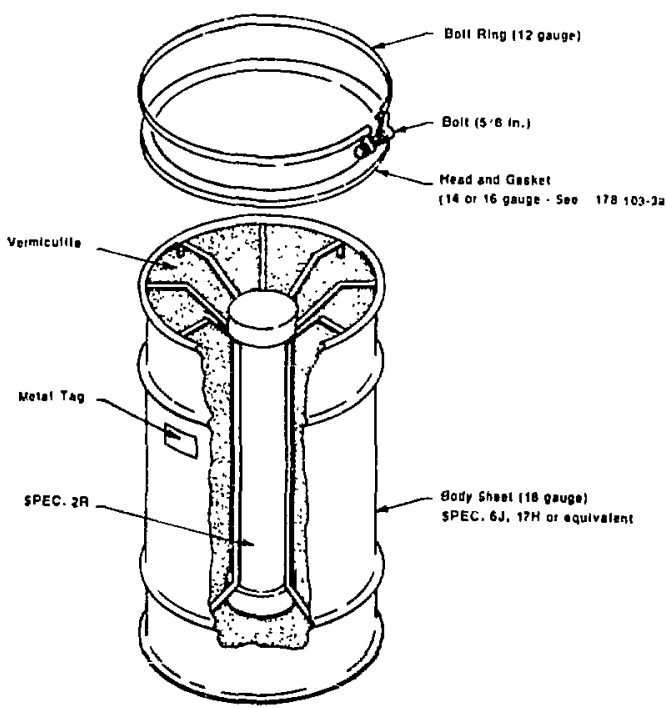




\section{c. Use of Nonspecification Packaging}

Acceptable packagings can be chosen from DOT specifications, but there are only a few from which to choose. One of the main questions is whether their volumes are practicable. Another question is whether they would be acceptable as terminal storage containers; although they are accepted by DOT for transportation, their acceptance by disposal-facility criteria must be determined. If DOT specification packaging is impracticable in the case of an airborne waste, the regulations can be used to indicate what tests would be required of other packaging that might be designed especially for this waste. The performance of nonspecification packaging in these tests can be evaluated either by engineering calculations or by physical tests on a prototype.

Table IV-14 includes, in addition to several specification packagings, the use of packaging that is approved by an agency or that meets regulatory requirements. Nonspecification packagings would have to be shown capable of meeting tests in licensing proceedings. Although the use of specification packaging would avoid the time and cost of design, testing, and licensing procedures, there are two important reasons why it might not be adequate for transportation of airborne wastes in the nuclear fuel cycle. First, the volume limits of specification packaging might require an unreasonably large number of packages. Second, the characteristics of DOT-specification packaging might not be compatible with acceptance criteria for terminal storage. In final emplacement, it would be convenient to use the container that the radioactive material was shipped in. Thus, it may be necessary to design a container that would conform to shipping regulations, provide a reasunably large capacity, and conform to acceptance criteria for final emplacement.

If a proposed design were to be used to ship airborne wastes in Type A packaging, it would have to be shown capable of meeting the general design requirements of 49 CFR 173.411 and the additional design requi zements for Type A packaging that are summarized in 49 CFR 173.412. Furthermore, a proposed Type A packaging would have to be shown capable uf withstanding the tests that are representative of normal conditions of transportation described in 49 CFR 173.465 (Table IV-16). On the other hand, a proposed Type B packaging would be required to meet the general design requirements of 49 CFR 173.411 and the Type $B$ design requirements of 10 CFR 71 . Furthermore, it must be demonstrated to be capable of withstanding the tests representative of normal conditions of transport described in 49 CFR 173.465 ( Table IV-16) and also the tests representative of accident conditions described in $10 \mathrm{CFR} 71$ (Table IV-17).

A number of packaging designs, other than DOT specification packagings, are catalogued [WAGH-1279, NUREG-0383]. These have been licensed by AEC, ERDA, or NRC. Some of these packagings may be adaptable for transportation of airborne wastes, but, since they are licensed for a specific cargo, their use for airborne wastes would require amendment. Thus, if packagings other than those specified in DOT ruies are to be used, the adaptation of catalogued packaging could save the cost and effort of design and testing, though relicensing is unavoidable. 
Table IV-16. Tests for Proposed Packagings: Normal Conditiors of Tranpertationa

- Water Spray

- Free drop

- Compression

- Penetration
Must precede each test or test sequence; simulates exposure to rainfall of $5 \mathrm{~cm} / \mathrm{h}$ for $1 \mathrm{~h}$. Must allow maximum soak-in before applying succeeding test.

Is made onto target to cause maximum damage, distance and procedure specified according to design and weight of package. $b$

Is applied for $24 \mathrm{~h}$, at five times weight of package or $1300 \mathrm{~kg} / \mathrm{m}^{2}$ times vertically projected area of package, whichever is greater; applied uniformly to two opposite sides, one of which is the base of the package.

Drop made through $1 \mathrm{~m}$ distance of $6 \mathrm{~kg}$ bar with $3.2-c m$ dia and hemispherical end onto package. $c$

${ }^{a}$ From [49 CFR 173.465].

b

Distance for free drəp test set at 9 th for Type A packagings designed to contain liquids and gases [49 CFR 173.466].

${ }^{c}$ Distance for penetration test set at $1.7 \mathrm{~m}$ for Type A packagings designed to contain liquids and gases [49 CFR 173.466].

Table IV-17. Tests for Proposed Packagings: Accident Conditionsa

- Free drop - A drop through a distance of 9.1 m onto an unyielding surface striking the surface in the position which would produce maximum damage.

- Functure - A free drop through a distance of $1 \mathrm{~m}$ onto a cylindrical steel bar $(15.2 \mathrm{~cm} \mathrm{dia)} \mathrm{with} \mathrm{the} \mathrm{edge} \mathrm{rounded} \mathrm{to} \mathrm{a}$ radius of $6.4 \mathrm{~mm}$. The length of the bar is selected for maximum damage (minimum length is $20.3 \mathrm{~cm}$ ). The bar is mounted on an unyielding horizontal surface and the package is dropped in a position expected to produce maximum damage.

- Thermal - Exposure to the equivalent of an $800^{\circ} \mathrm{C}$ fire for $30 \mathrm{~min}$ with no artificial cooling for three hours after the exposure.

- Hydro - Water immersion (fissile material packages only) at a depth of $91 \mathrm{~cm}$ for eight hours.

${ }^{a}$ Subject to change in the revision of [10 CFR 71]. Tests applied sequentially to determine cumulative effect on the package. 
A survey of available systems and equipment for transportation of radioactive materials was published in 1976 [JEFFERSON-1976]. Also, detailed descriptions of certified puckaging have been issued periodically [WASH-1279, NUREG-0383, EDLING]. Recently, information on appropriate packaging for transportation of radioactive materials has been placed into computer storage at the SANDIA Transportation Technology Center (TTC). This information bank, the TTC Database of Certified Packagings for Radioactive Materials (RAMPAC Database), will output a description of appropriate transportation equipment in response to an input description of the waste [EMERSON].

It has been suggested [JEFFERSON-1982] that the RAMPAC Database might be searched to obtain descriptions of transportation equipment that could be applied to airborne waste forms. Plans for the analysis forming the second part of this program included assembly, for each airborne isotope, of a reference description of the most probable waste form and its packaging. Therefore, the RAMPAC Database will be used wherever possible to assemble these descriptions of a complete waste management system for each airborne isotope.

\section{d. Requirements of the Licensing Process}

Shipments of airborne wastes would require NRC 1 icensing not only if nonspecification packaging were employed as discussed above, but also if shipments of Type $B$ quantities or large quantities of radioactive materials even at low specific activity were involved. The general responsibilities of the shipper in the licensing process are to show that the packaging and vehicles involved conform to the Code of Federal Regulations, to describe the procedure that would be used in case of accident, to describe controls and precautions that will be used in handling packages, and to describe inspection and accountability proredures.

\section{e. Limitation of External Radiation in Shipments}

In addition to the concerns for containment, expressed in the specification of packaging construction discussed above, dose rates to the public and to shipping personnel are to be controlled through a transport index and aiso through a list of sperifications on dose limits.

The transport index is a number placed on a package of radioactive material to designate the degree of control to be exercised by the carrier during transportation. For packages that do not contain fissile material, the transport index is the highest radiation dose rate in mrem/h at 1 m from any accessible external surface of the package.

Radiation dose limits for exclusive-use shipments are summarized in Table IV-18.

\section{Packaging for Deep Geologic Disposal}

The waste package for disposal of long-lived nuclear wastes is an engineered barrier system consisting of the waste form and a canister or container forming a protective sealed envelope for the waste form. Barriers between the container and the geologic site also play a role in the engineered 
Table IV-18. Radiation Dose Limits for Exclusive-Use Shipments

- $1000 \mathrm{mrem} / \mathrm{h}$ at accessible external surface of packagea,b

- $200 \mathrm{mrem} / \mathrm{h}$ at any point on outer surface of vehicleb

- $10 \mathrm{mrem} / \mathrm{h}$ at any point $2 \mathrm{~m}$ from vertical planes represented by outer lateral surfaces of vehicle $e^{b}$

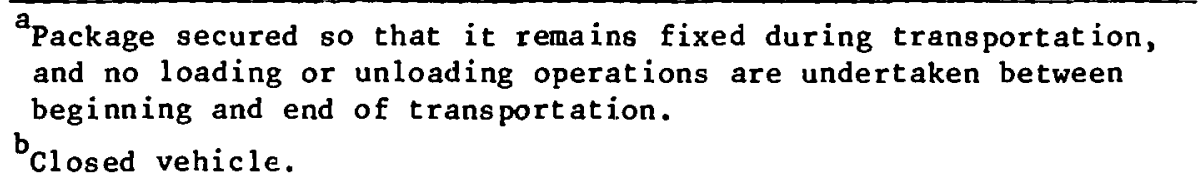

system. One concept for such a system being investigated at PIL [WESTERMAN] is shown in Fig. IV-5. The primary barrier in these concepts is the canister, and appropriate materials are being investigated for use in these containers [PITMAN]. The container must not be degraded by the contained waste or by interaction with the barriers or other components in the geologic site. Corrosion tests [PITMAN] were conducted on various proposed container materials when exposed to a potential groundwater or to a brine solution (salt dome). Results of these screening test: indicated that various nickel alloys, titani un alloys, and austenitic stainless steels exhibited low corrosion rates; however, the austenitic stainless steels could be subject to chloride stress corrosion cracking. Ceranic and polymeric materials are also being investigated as isolation barriers between the canister and the geologic repository environment [FULLAM]. The container matcrial would have to be evaluated against any selected barrier material for corrosion or other reactions.

Several alloys were also investigated by Sandia [MAGNANI] for corrosion resistance suitable for a 300 y lifetime. Titanium-Code 12 was found to be a very corrosion-resistant material in hedded salt or seabed environments and worthy of further investigation.

Materials suitable in clay environments are being investigated at Centre d'Etudes de l'Energie Nucleaire, Mol, Belgium [CASTEELS]. In the clay environment, sulfur appears to affect reactions with the metals, and Hastelloy C provided the best corrosion resistance.

\section{Packaging for Shallow-Land Burial}

\section{a. Definitions and Present Status}

An EPA-sponsored survey describes the types of packaging most commonly used in the management of LLW [MILLiLR]. The conclusions of this survey are summarized here. For this discussion, it is understood that the term low-level wastes is used to describe any radioactive wastes other than (1) high-level (the raffinate from the first cycle of the reprocessing of spent nuclear fuel), (2) TRU (wastes containing $\geq 10 \mathrm{nCi} / \mathrm{g}$ of transuranium nuclides or $U-233$ ), and (3) mine or mill tailings. 


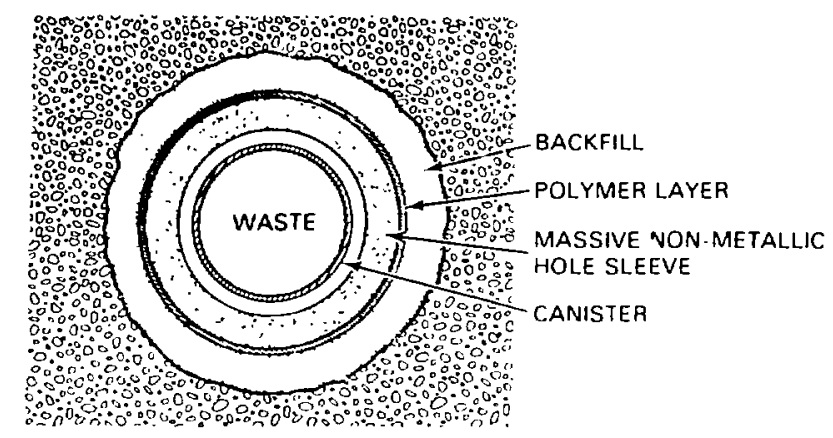

- Number of engineered barriers. exclusive of waste form 4 (canister. conciete, polymer, backilli)

- Materials for canister $\mathrm{Cu}, \mathrm{Cu}$-base alloys, Fe base, Ni-base alloys

- Materials for hote sleeve Concrela, polymer concrete, ceramics,graphite

Fig. IV-5. Engineered Barrier System Compatible with Both Oxidizing and Anoxic Environments, Featuring Massive NonMetallic Hole sleeve

In the discussion of packages and packaging, the term "packaging" refers to all contaiment components, including wrappers, structural members, shielding, seals, and covers. The term "package," on the other hand, refers to the combination of packagin plus cargo that is contained within it; in this case, the radioactive waste.

One of the main concerns pointed up by this survey is the lack of common basis of criteria and standards for packaging. This situation is expected to be remedied by the adoption of $10 \mathrm{CFR} 61$. The survey of [MILLER] is useful for its description of the types of containers most commonly used in SLB, i.e., steel drums, larger steel containers, and non-metal packaging. A useful summary of such packaging is also provided in [ONWI-20].

\section{b. Criteria, Standards, Regulations for Packaging of LLW}

In the past, the packaging of LLW has been guided by tenets from three sources: rules of the waste-generating facility, Federal transportation regulations, and rules of the waste-accepting facility. Criteria for acceptance of packages at commerical burial grounds have generally coincidest with the DOT construction requirements, al though some additional requirements have been imposed by the generating or burial facilities, mainly to accommodate whatever drum-handling equipment is available. Transport regulations have been constructed to ensure container integrity during transport, without regard for performance in burial.

Although the packaging is considered responsible for containment of LLW in transportation, this is not the case at the burial grounds. At these sites, it is the soil rather than the packaging that has been considered to be the containing element. Although DOT specifications on 
containers are intended to ensure their integrity during transportation, the contalners are not strong enough to survive some operations used to place containers in SLB trenches.

The DOT spec. $17 \mathrm{C}$ or $17 \mathrm{H}$ drums are required to sustain a drop of $4 \mathrm{ft}$ onto concrete. In the past, such contalners have been dropped from hel ghts greater than $4 \mathrm{ft}$ into SLB trenches, in some cases onto other conta1ners [MILLER]. Present-day burlal operations treat containers with more care [LEV IN-1982].

\section{c. Steel Drums}

The container most often used for packaging of LLw is the steel drum. Steel drums are relatively inexpensive, easy to handle, and have been accepted at all SLB sites. Although 55-gal drums are most often employed, drums of $30-\mathrm{gal}$ and imaller capactites have also been used.

Drums used to package LLW are usually coated on all surfaces with paint, but such coatings are not expected to significantly extend iffetimes of drums in contact with soil. Additional contalnment within the steel drum, consisting of plastic bagging or a rigid polyethylene drum, is commonly used. When shielding is required, liners of concrete or other material have been placed inside the drums, but limits on total welght are specified both by DOT rules and by acceptance criterla of burlal grounds. Usually nondisposable, reusable exterior shlelds are used for transportation and handling.

For some cargoes, the steel drum offers the desirable comblnation of acceptability for transportation (DOT-approved drums) and also acceptability for burial. For other cargoes, however, steel druns qualify for burial but not for shipping. In such cases, the drums are shipped within an overpack that provides the required shipping qualifications. For example, the "Super T1ger" Is an unshlelded, Type B overpack that can contain up to 42 drums (55(a1) for transport by truck, rail, or barge [JEFFERSON-1976]. Sh1elded overpacks have smaller capacities. On arrival at the burlal ground, the drums are removed from the overpack and burled. The overpack is returned for reuse. At present this is probably the most common methodology for shielding wastes In drums.

The 55-gal drum, typlcal of much of the packaglng used for SLB, Is of ten ued with a concrete matrix contalning up to 25 vol \% waste [MILLER]. Excess water may be released from the matrix after the drum 13 closed, resultIng in corrosion of the interior surfaces of the drum. The use of a concrete matrix gives structural support to the package so that the drum is less suscept1ble to belng punctured. Moreover, in the event of drum puncture, the matrix retards dispersal of the waste to the environment.

\section{d. Large Steel Contalners}

Contalners larger than the 55-gal drum have come into use for low-density wastes that must be disposed of regularly in large volume. These contalners have capacities many times that of the 55-gal drum. For example, 
low-activity LLW has been shipped in containers of 1200-1400 gal* with shielding equivalent to 2 in. of lead. Also, LIW of higher activity has been shipped in containers of $500 \mathrm{gal}$ with shielding equivalent to 4 in. of lead. These containers are conetructed from 1/4-in. carbon steel, using welded seams. They are transported in a Type B overpack to prevent damage from impacts. With these large coniainers, a matrix such as cement is not used, probably because of weight limitations. Without the support of a matrix on inside surfaces, they are susceptible to damage from impacts. Because of their 1/4-in. walls, these containers can be expected to have a much longer lifetime in soil than steel drums which have much thinner walls.

\section{e. Non-Metal Containers}

In general, non-metal packaging has been more readily accepted at DOE burial sites than at commercial burial sites. Cardboard boxes are unacceptable at commercial burial sites, and other non-metal packaging has been limited to DOT-approved designs. At DOE burial sites, on the other hand, examples of non-metal packaging include (1) sealed plastic bags within cardboard boxes or fiberboard drums, (2) plastic-lined fiberboard boxes, and (3) liners of PVC or fiberboend within DOT 7A plywood boxes.

Fiber-drum packaging is representative of practices at DOE burial grounds where public transportation systens and, therefore, DOT regulations are not involved. Packages involving fiber drums are typically carried from a lab area and dumped directly into a burial trench.

\section{F. Interim Storage}

Interim storage is commonly understood to be an arrangement for temporarily storing a waste form after conversion of the primary form to a suitable storage form and packaging, but before emplacement in a terminal storage situation. In some cases, re-packaging may be planned between interim storage and terminal storage. The general system of options is diagramed in Fig. IV-6.

Interim storage might be used for several reasons, only some of which may be useful for airborne wastes. (1) The radioactive isotopes may be allowed to decay to reduce the heat generation rate or the specific activity to levels necessary to geet transportation regulations or acceptance criteria at a desired terminal storage facility. This isotope decay would avoid distributing the waste among an unreasonably large number of packages or committing uneconomically large amounts of shielding to terminal storage. (2) Interim storage may be necessary to permit time for decisions to be made on selection of waste form and the process by which it will be produced. (3) lt may be necessary to store a waste pending the R\&D required to develop the process operations used to produce the terminal waste form. (4) It may be necessary to store a waste to await regulatory developments, including formulation of criteria and promulgatio of regulations. (5) Interim storage may be necessary pending the design and construction of a terminal disposal facility.

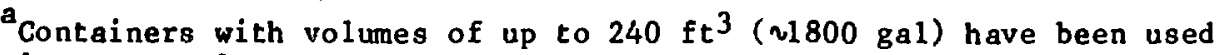
[LEV IN-1982].
} 


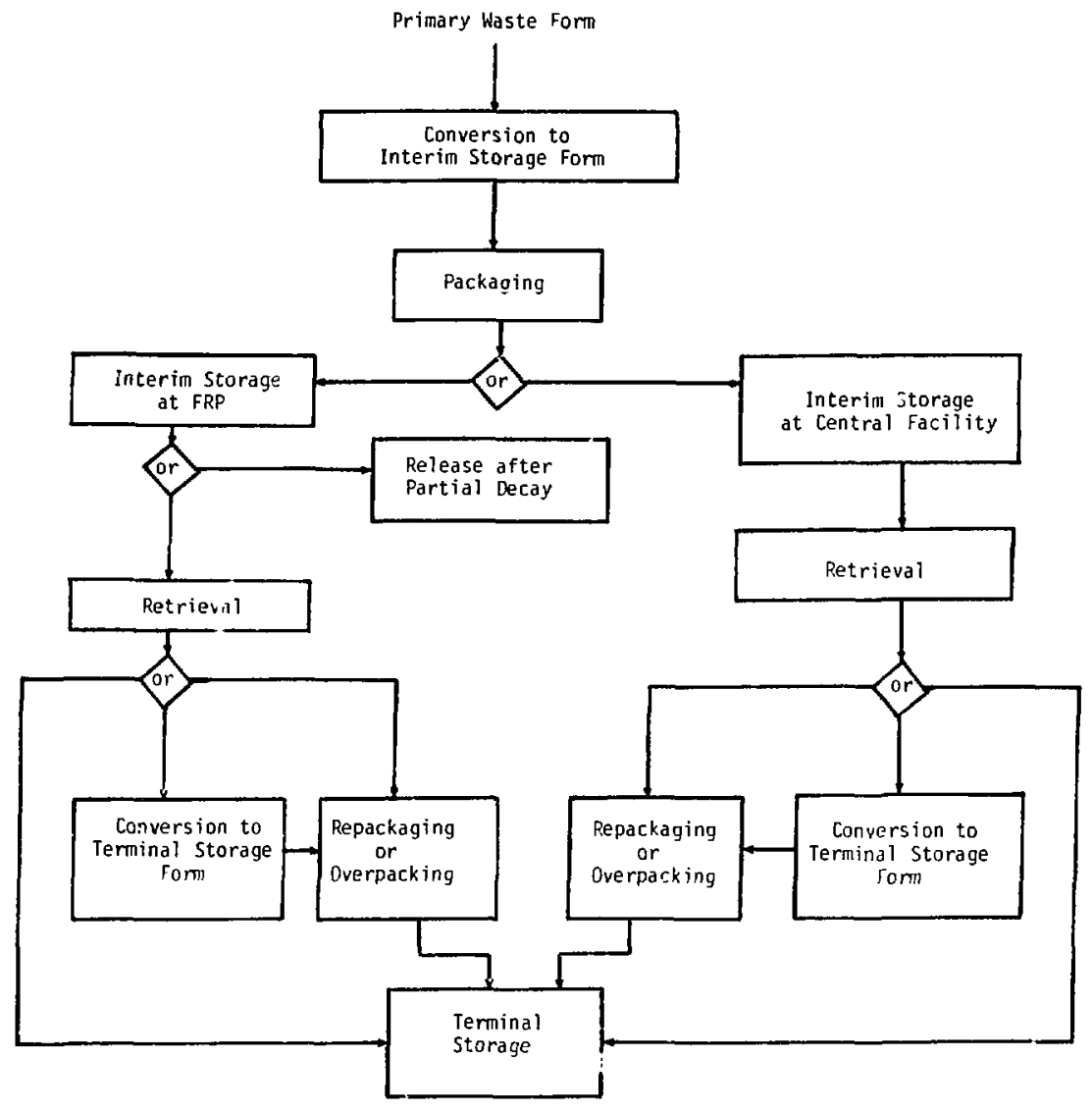

Fig. IV-6. Options Related to Interim Storage

At present, TRU wastes are being received for interim storage (or "retrievable" storage) at a facility at Hanford, operated by the RockwellHanford Company [MCCALL] and also at the Radioactive Waste Management Complex, operated by the EG\&S Co. on the INEL site [ANDERSON].

For $\mathrm{Kr}-85$ and tritium, which have half-1ives of only about one decade, interim storage until the radioactivity amounts are low enough to permit release, with dilution by air to the environment, has been suggested. A detailed description of a facility for storing krypton at an FRP site is deaigned with the intention of storage for $50 \mathrm{y}$, at which time controlled release to the atmosphere would be started [DOE/ET-0028]. Less-detailed concepts for interim storage of tritiated water [NEA, GRIMES] have similarly suggested storage for about the same time period, ending in discharge to the envi ronment. 
Although most of the technology of interim storage of non-high-level solid wastes is aimed at TRU-contaminated wastes, sone technology seems adaptable to interim storage of airborne wastes. For example, the brief summary of packaging for interim storage of TRU wastes [ERDA-76-43A] might be applied to interim storage of solid airborne waste forms. 


\section{v. SUMMARY}

In preparation for an analysis of compliance of technologies for waste management of the airborne nuclides ( $\mathrm{H}-3, \mathrm{I}-129, \mathrm{C}-14$, and $\mathrm{KI}-85$ ), an informa$t$ ion base was assembled and is summarized here. The topics considered in this assembly include processes for the collection of airborne nuclides from streams of fuel reprocessing plant $\dot{s}$, conversion of primary waste to forms suitable for disposal, requirements on waste forms and packaging made by transportazion regulations and by technical criterial for final disposal, and characteristics of disposal facilities and the procedures used at them in emplacement of waste packages. The disposal modes considered irclude shallowland burial, greater confinement disposal, deep geologic disposal, temporary storage on the site of the fuel reprocessing plant, and ocean disposal.

Based upon this information, a complete waste management system that could be assembled for each nuclide from the technologies that have been developed to date will be briefly described and then the question of whether such a system could comp'y with the applicable regulations will be addressed.

The survey reported here indicates that much information relevant to management of airborne nuclides is available. It also indicates that, although the technologies have been tested at varying fractions of full-scale and at varying degrees of simulation of real systems, none has been tested in fullscale use.

In general, most of the development of collection processes and waste forms seems to have been done before the regulations that define the criteria to be met by the waste management technology were issued in final form. Furthermore, many of the concepts or models of expected performance of waste management technology in full-scale practice have not been developed in the detail or in the form that would permit ready comparison with the requirements of zegulations, especially requirements that are expressed as quantitative limits on dose rates. The large body of information assembled here seems to be sufficient, however, to provide the material for predictions on where com$\mathrm{pl}$ iance may and may not be expected and indications on where development of either technology or regulations would contribute to yielding complete disposal s.rangements for the airborne nuclides. 


\section{REFERENCES}

ALLARD-1980

B. Allard, B. Torstenfelt, K. Andersson, and J. Rydberg, Possible Retention of Iodine in the Ground, Scientific Basis for Nuclear Waste Management, C. J. M. Northrup, Ed., Plenum Press, New York, Vol. 2, p. $673(1980)$.

ALLARD-1981

B. Allard, B. Torstenfelt, and $\mathrm{K}$. Andersson, Sorption Studies of $\mathrm{H}^{14} \mathrm{CO}_{3}{ }^{-}$ on Some Geologic Media and Concrete, Sclentific Basis for Nuclear Wasts Management, J. G. Moore, Ed., Plenum Press, New York, Vol. 3, p. 465 (1981).

\section{ALTOMARE}

P. M. Altomare, M. Barbier, N. Lord, and D. Nainan, Assessment of haste Management of Volatile Radionuclides, prepared for the U.S. Environmental Protection Agency by the Mitre Corporation, ORP/CSD 79-2 (May 1979).

\section{ANDERSON}

B. C. Anderson, Criterla for Packaging Transuranic Waste for Recelpt at the Idano National Engineering Laboratory Waste Management Complex, Offsite Generated Waste, Nuclear Fuel Cycle Division, Idaho Operations Office, U.S. Dept. of Energy Report IDO-10074, Rev. 1 (Apr11 1980).

\section{ARBITAI}

J. Arbital, E. Bettis, T. Myrick, H. Watts, R. Willems, and H. Yook, Considerations for Development of Specifications for Subsurface Waste Handling Equipment, Science Applications Inc., Oak Ridge, TN, prepared for Batteile office of Nuclear Waste Isolation, Report ONWI-75 (October 1979).

ARNOLD

W. D. Arnold, R. Salmon, K. H. LIm, and W. de Laguna, Preliminary Evaluation of Methods for the Disposal of Tritiated Water from Nuclearly StImulated Natural Gas Wells, Oak RIdge National Laboratory Report ORNL-TM-4024 (Apr11 1973).

BARNES

M. W. Barnes, B. E. Sheetz, L. D. Wakely, S. D. Atkinson, and D. M. Roy, Stability of $I$ and Sr Radiophases in Sement Matrices, Scientific Basis for Nuclear Waste Management, Proc. of the Mater1a1s Research Society Annual Meeting, November 1981, S. V. Topp, Ed., North-Holland

Publish1ng Co. Inc., New York, Vol. 6 (1982).

BASOLO

F. Basolo and R. G. Pearson, Mechanlsms of Inorganic Reactions,

John Wiley and Sons, Inc., New York (1968).

\section{BAUMEISTER}

T. Baumeister and L. S. Marks, Standard Handbook for Mechanical Engineers, 7th Ed., McGraw-H111, New York (1967). 
BECHTEL

Bechtel National Inc., National Waste Terminal Storage (NWTS), Conceptual

Reference Repository Description (CRRD). Volume III, Criteria, Bases, Special Studies, and Codes, prepared for Battelle Office of Nuclear Waste Isolation (September 1979).

BENDIXSEN-1968

C. L. Bendixser. and G. F. Offutt, Rare Gas Recovery Facility at the Idaho Chemical Processing Plant, Idaho Nuclear Corp. Report IN-1221 (April 1968).

BENDIXSEN-1971

C. L. Bendixsen and F. 0. German, Operation of the ICPP Rare Gas ractitity During Fiscal Year 1970, Idaho Chemical Programs Operations office, Allied Chemical Corp. Report ICP-1001 (October 1971).

BEND LXSEN-1973

C. L. Bendixsen and J. A. Buckham, General Survey of Techniques for Separation and Containment of Noble Gases from Nuclear Factlities. Symp. On Noble Gases, sponsored by the U.S. EPA and University of Nevada-Las Vegas, Las Vegas, NV, September 24-28, 1973, CONF-730915-16.

BENDIXSEN-1975A

C. L. Bendixsen, F. O. German, and R. R. Hammer, 1972 Operations of the ICPP Rare Gas Recovery Facility, Idaho Chemical programs Operations office, Allied Chemical Corp. Report ICP-1023 (March 1975).

BENDIXSEN-1975B

C. L. Bendixsen, F. O. German, 1974 Operations of the IC:P Rare Gas Recovery Facility, Idaho Chemical Programs Operations office, Allied Chemical Corp. Report ICP-1057 (March 1975).

BENDIXSEN-1976

C. L. Bendixsen and D. A. Knecht, Separation and Storage of Krypton, Proc. Int. Symp. on the Management of Wastes from the LWR Fuel Cycle, Denver, C0, JuIy 11-16, 1976, CONF-760701, P. 343 (1976).

BENEDICT-1955

M. Benedict, Survey of Heavy-Water Production Processes, Proc. Int. Conf. on the Peaceful Uses of Atomic Energy, Geneva, August 8-20, 1955, United Nations, New York, Vol. 8, pp. 377-405.

BENEDICT-1 1979

R. W. Benedict, A. B. Christensen, J. A. Del Debbio, J. H. Keller, and D. A. Knecht, Technical and Economic Feasibility of Zeolite Encapsulation for Krypton-85 Storage, Exxon Nuclear Idaho Company, Inc. Report ENICO-1011 (September 1979).

BEONE

G. Beone and I. Di Stefano, Incorporation of Silver-Coated Zeolites in Cement. Part I. Study on Variables and Preliminary Results, Comitato Nazlonale Energla Nucleare, Rome, Italy, CNEN Report RT/PROT(79)17 (1979). 
N. E. Bibler and E. G. Orebaugh, Radiolvtic Gas Production from Tritiated Waste Forms, E. I. du Pont de Nemours and Co., Savannah River Laboratocy Report DP-1459 (July 1977).

BIRD

G. W. Bird and V. J. Lopata, Solution Interaction of Nuclear Waste Antong and Selected Geological Materials, Scientific Basis for Nuclear Waste Manag ement, C. J. M. Northrup, Jr., Ed., Plenum Press, New York, Vol. 2, p. 419 (1980).

BISWAS

P. K. Biswas, R. Ajoy, K. Nag, Unusual Phase Transition of Barium Iodate, Thermochim. Acta 42,91 (1980).

BIXEL

J. C. Bixel and C. J. Kershner, A Study of Catalytic 0xidation and oxide Adsorption for the Removal of Tritium from AIr, Proc. of the Second AEC Environmental Protection Conf., Albuquerque, NM, April 16-19, 1974, U.S. Atomic Energy Commission Report WASH-1.332(74) (July 1974).

BLANCETT

A. L. Blancett, Engineering Design of Integrated Hot Off-Gas Facility, E.J. du Pont de Nemours and Co., Savannah River Laboratory keport DP-1628 (March 1982).

BLAUVELT

R. Blaurelt, Monsanto Mound Facility, private communication to

J. D. Christian, Exxon Nuclear Idaho Co., Inc., August 1981 .

BNWL

High-Level Radioactive Waste Management Alternatives, K. J. Schneider and A. M. Platt, Eds., Battelle Pacific Northwest Laboratories Report BNWL-1900 (May 1974).

BOND

W. D. Bond, Chemica: Aspects of Nuclear iaste Treatment, Anerican Chemical Society Southeast-Southwest Regional Meeting, New Orleans, LA, December 10,1980 , CONF-801226-2 (1980).

BOUSQQUET-1968

J. Bousquet, J. C. David, D. Mathurin, and G. Perachon, Determination of the Standard Enthalpy of Formation for Some Iodates and Periodates, Bul1. Soc. Chim. Fr., pp. 3991-3 (1968).

BOUSQUET-1969A

J. Bousquet, D. Mathurin, and P. Vermande, Solubility of Anhydrous and Hydrated Calcium, Strontium, and Barfum Iodates in Aqueous Solutions, Bull. Soc. Chim. Fr., p. 1111 (1969).

BOUSQUET-1969B

Jo Bousquet, M. Diot, A. Koob, and D. Mathurin, Determination of the Molar Heat Capacity of Barium Iodate at 10-650 K, C. R. Acad. Sci. Ser. C. 269(6), 405-407 (1969). 
BOYARINOVA- 1972

L. G. Boyarinova, R. E. Zhaimina, and A. I. Mun, Coprecipitation of Iodate Ion with Metal Hydroxides, Izv. Akad. Nauk Kaz SSR, Ser. Khim. 22, 6; Cheraical Abstracts 78:62952 f (1972).

BOYARINOVA-1973

L. G. Boyarinova, A. I. Mun, and R. E. Zhaimina, Sorption of Iodine by Silt and Sapropel, Izv. Akad. Nauk Kaz SSR, Ser. Khim. 23, 72; Chemical Abstracts 79:23450s (1973).

BRAUN-1980

H. Braun, H. Bonka, D. Gründler, H, Gutowski, and J. Weber, Retention of Carbon-14 in Nuclear Facilities, Proc. Int. Symp. on Management of Gaseous Wastes from Nuclear Facilities, Vienna, February 1980 , IAEA Report IAEA-SM-245/9, p. 211 (1980).

BRAUN -1983

H. Braun, H. Gutowski, H. Bonka, and D. Gründler, Plant for: Retention of ${ }^{14} \mathrm{C}$ in Reprocessing Plants for LWR Fuel Elements, Proc. 17th DOE Nuclear Air Cleaning Conf., M. W. First, Ed., CONF-820833, Vol. 1, p. 381 (February 1983).

BRAY

L. A. Bray, L. L. Burger, L. G. Morgan, and D. L. Baldwin, Thermal Release of Volatile Fission Products from Irradiated Nuclear Fuel, Hanford Engineering Development Laboratory, Pacific Northwest Laboratory Report PNL-4488, in publication (Septembar 1982).

BRECK

D. W. Breck, Zeolite Molecular Sieves--Structure, Chemistry and Use, John Wiley and Sons, Inc., New York (1974).

\section{BROOTHAERTS}

J. Broothaerts, G. Dollard, A. Bruggenen, W. R. A. Goossens,

L. H. Baetsle, and $\mathrm{K}$. Glibert, Treatment and Control of Gaseous

Effluents from Light Water Reactors and Reprocessing Plants, Proc.

Symp. on the Management of Radioactive Wastes from the Nuclear Fuel

Cycle, Vienna, March 22-26, 1976, IAEA Report IAEA-SM-207/8, STI/PUB/433,

Vo1. 1, p. 114, (1976).

BROWN-1976

R. A. Brown, Managenent of Tritium and Carbon-14, Proc. Int. Symp.

on the Manegement of Wastes from the LWR Fuel Cycle, Denver, Co,

July 11-16, 1976, CONF-76-0701, p. 364 (1976).

BROWN- 1978

R. A. Brown, D. A. Knecht, and T. R. Thomas, Reference Facility

Description for the Recovery of Iodine, Carbon, and Krypton from

Gaseous Wastes, Idaho Chemical Programs Operations office, Allied Chemical Corporation Report ICP-1126 (April 1978). 
BROWN-1980

R. A. Brown, J. D. Christian, and T. R. Thomas, Program Strategy Reference Document for the Management of Radloactlve Alrborne Wastes, Draft, Waste Management Program Office, Exxon Nuclear Idaho Company, Inc.

(September 1980).

BROWN-1981

R. A. Brown, J. D. Christian, and T. R. Thomas, Program Strategy Document for the Management of Radioactive Airborne Wastes, Draft Copy, Exxon Nuclear Idaho Company, Inc. (1981).

BRUGGEMAN-1979

A. Bruggemar:, L. Meynendonckx, and W. R. A. Goossens, Elimination of $\mathrm{NO}_{\mathrm{X}}$ by Selective Reduction with $\mathrm{NH}_{3}$, Pros. 15th DOE Nuclear A1r Cleaning Conf., Boston, MA, August 7-8, 1978, U.S. Dept. of Energy Report CONF-780819, pp. 614-625 (February 1979).

\section{BRUGGEMAN-1980}

A. Bruggeman, W. Doyen, R. Harnie, R. Leysen, L. Meynendonckx, M. Monsecour, W. K. A. Goossens, and L. H. Baetsle, Separation of Tritium from Reprocessing Effiuents, Management of Gaseous Wastes from Nuclear Fac1lities, IAEA Report IAEA-SM-245/52, pp. 157-175 (1980).

BURGER-1974

L. L. Burgt $r$ and J. L. Ryan, The Technology of Tritium Fixation and

Storage, Battelle Northwest Laboratorles Report BNWL-1807, R1chland, WA (January 1974).

BURGER-1976

L. L. Burger and L. E. Trevorrow, Release of Tritium from Fuel and Collection for Storage, Proc., Controlling Alrborne Effluents from Fuel Cycle Plants, Toplcal Meeting by the American Nuclear Soclety and the American Institute of Chemical Engineers, Sun Valley, Idaho, August 5-6, 1976, American Nuclear Society, Hinsdale, IL (1976).

BURGER-1978

L. L. Burger and R. D. Scheele, Tritlum Removal Alternatives for the

Purex Process, Pacific Northwest Laboratory Report PNL-2080-14 (March 1978).

BURGER-1979A

L. L. Burger and R. E. Burns, Technical Requirements for the Control of 129 I in a Nuclear F'iels Reprocessing Plant, Pacific Northwest Laboratory Report PNL-3186 (November 1979).

BURGER-1979B

L. L. Burger and R. D. Scheele, Separation of Iodine from Mercury-

Containing Scrubbing Solutions, U.S. Patent 4, 1.62, 206 (July 24, 1979).

BURGER-1980

L. L. Burger, Determining Criteria for the Disposal of Iodine-129,

Pacific Northwest Laboratory Report PNL-3496 (October 1980). 
BURGER-1981A

L. L. Burger, R. D. Scheele, and K. D. Wiemers, Selection of a Form for Fixation of $129 \mathrm{I}$, Pacific Northwest Laboratory Report PNL-4045

(December 1981).

BURGER-1981B

L. L. Burger and R. D. Scheele, Iodine Fixation Studies at the Pacific Northwest Laboratory, Pacific Northwest Laboratory Report PNL-SA-9829 (1981).

BURGER-1982A

L. L. Burger, Thermal Outgassing, Nuclear Waste Management, Semiannual

Progress Report, Oct. 1981-March 1982, Pacific Northwest Laboratory Report PNL-4250-1 (1982).

BURGER-1982B

L. L. Burger, Pacific Northwest Laboratories, private communication to

L. Trevorrow (October 1982).

BUTLER

J. P. Butler, Hydrogen Isotope Separation by Catalyzed Exchange Between

Hydrogen and I.iquid Water, Sep. Sci. Technol. 16, 371 (1980).

CARD

D. H. Card, P. H. Hunter, J. A. Adam, and R. B. White, Criteria for Greater Confinement, Ford, Bacon \& Davis Utah, Inc., U.S. Dept. of Energy Report DOE/ID/01570--T20 (also NVO-234) (May 198I).

\section{CASTEELS}

F. Casteels, H. Tas, J. Naets, and M. Brabera, Corrosion of Materials

in a Clay Environment, Scientific Basis for Nuclear Waste Management,

C. J. M. Northrup, Ed., Plenum Press, New York, Vol. 2, p. 385 (1980). CHEH

C. H. Cheh, R. W. Glass, and V. S. Chew, Removal of Carbon-14 from Gaseous Streams, paper prepared for pressntation at the IAEA Seminar on the Testing and Operation of off-Gas Cleaning Systems at Nuclear

Facilities, Karlsruhe, Federal Republic of Germany, May 3-7, 1982.

CHEW

V. S. Chew, C. H. Cheh, and R. W. Glass, Mechanism of the $\mathrm{CO}_{2}-\mathrm{Ca}(\mathrm{OH})_{2}$

Reaction, Proc. 17th DOE Nuclear Air Cleaning Conf,, M. W. First,

Ed., CONF-820833, Vo1. 7, p. 400 (February 1983).

CH IKALLA-1980

T. D. Chikalla and J. A. Powe11, Compilers, Nuclear Waste Management Quarterly Progress Report, July-September $19 \overline{80, \text { Section } 8 \text {, Iodine-129 }}$ Fixation, Pacific Northwest Laboratory Report PNL-3000-7 (1980).

CHIKALLA-1981A

T. D. Chikalla and J. A. Powe11, Compilers, Nuclear Waste Management Quarterly Progress Report, January-March 1981, Section 8, Iodine-129 Fixation, Facific Northwest Laboratory Report PNL-3000-9 (I981). 
CHIKALLA-1981 B

T. D. Chikalla and J. A. Powel1, Compilers, Nuclear Waste Management Quarterly Progress Report, October-December 1980, Section 8, Iodine-129 Fixation, Pacific Northwest Laboratory Report PNL-3000-8 (1981).

CHIKALLA-1981C

T. D. Chikalla and J. A. Powell, Compilers, Nuclear Waste Management Quarter1y Progress Report, July-Scptember 1981, Section 9, Iodine-129 Fixation, Pacific Northwest Laboratory Report PNL-3000-11 (1981).

CHIKALLA-1982

T. D. Chikalla and J. A. Poweli, Compilers, Nuclear Waste Management Semiannual Progress Report, October 1981-March 1982, Section 3.2, Iodine-129 Fixation, Parific Northwest Laboratory Report PNL $-4250-1$, (1982).

CHLECK

D. J. Chleck and C. A. Zlegler, The Preparation and Some Propertles of Radioactive Quinol-Krypton Clathrate Compounds, Int. J. Appl. Radlat. Isot. 1,141 (1959).

CHRISTENSEN

A. B. Christensen, J. A. Del Debbio, D. A. Knecht, J. E. Tanner, and S. C. Cossel, The Immotilization of Krypton 85 in Zeolite $5 \mathrm{~A}$ and Porous Glass, Exxon Nuclear Idaho Co., Inc., U.S. Dept. of Energy Report ENICO-1102 (December 1981).

CHRISTIAN

J. Christian, Exxon Nuclear Idaho Corp., personal communication to

L. Trevorrow (October 1982).

CLARK-1975

W. E. Clark, '. T. Thomas, and W. B. Howerton, Flxation of Radiolodine with Portland vement, Part I: Preliminary ScopIng Studies, Oak RIdge National Laboratory Report ORNL-TM-5064 (December 1975).

CLARK-1976

W. E. Clark, Immobllization of ${ }^{129} \mathrm{I}$ as Barlum Iodate with Portland Cement, Trans. Am. Nucl. Soc. 23, 264 (1976).

CLARK-1977A

W. E. Clark and C. T. Thompson, Immobilizarion of Iodine in Concrete, U.S. Patent 4,017,417 (April 1977).

CLARK-1977B

$\because$. E. Clark, The Isolation of Radiolodine with Portland Cement, Part I: Scoplng Leach Studies, Nucl. Technol. 36, 215 (1977).

CLARK-1978

W. E. Clark and W. B. Howerton, The Radiolysis of Barlum Iodate in Portland Cement, Trans. Am. Nucl. Soc. 28, 349 (1978). 
CLARK- 1980

W. E. Clark and W. B. Howerton, The Fixation of Radioiodine with Portland Cement, Part II: Radiation Stability Tests, Nucl. Technol. 49, 209 (1980).

COHEN

J. J. Cohen, Cost Effectiveness of Release Prevention Controls for Tricium and Krypton-85, Combined Ef fects of Radioactive, Chemical, and Thermal Releases to the Environment, STI/PUB/404, International Atonic Energy Agency, Vienna, p. 285 (1975).

COLOMBO-TSDPR

P. Colombo et al., Tritium Storage Development Progress Report, Brookhaven National Laboratory Reports:

$$
\begin{aligned}
& \text { No. 12, Apr-Jun 1977, BNL-50733, } \\
& \text { No. 11, Jan-Mar 1977, BNL-50729, } \\
& \text { No. 10, Oct-Dec 1976, BNL-50728, } \\
& \text { No. 9, Jul-Sep 1976, BNL-50625, } \\
& \text { No. 8, Apr-Jun 1976, BNL-50583, } \\
& \text { No. 7, Jan-Mar 1976, BNL-21700, } \\
& \text { No. 6, Sep-Dec 1975, BNL-21348, } \\
& \text { No. 5, Jul-Sep 1975, BNL-20779. }
\end{aligned}
$$

COLOMBO-1974

P. Colombo, M. Steinberg, and B. Manowitz, Tritium Storage Development Progress Report No. 2, Octobe:-December 1974, Brookhaven National Laboratory Report BNL-19688 (January 1975).

COLOMBO-1977

P. Colombo and R. Johnson, Tritium Storage Development Progress Report No. 13, Brookhaven National Laboratory Report BNL-50758, July-September 1977 (1977).

COUTURE

R. A. Courure, M. G. Seitz, and M. J. Steindler, Adsorftion of Iodate by Hematite $\left(\mathrm{Fe}_{2} \mathrm{O}_{3}\right)$, Trans. Am. Nucl. Soc. 32,397 (1979).

CRANDALL

D. B. Crandall, Asternative Waste Disposal Concepts: An Interim Technical Assessment, Bachte! National, Inc., San Francisco, CA, prepared for Battelle Office of Nuclear Waste Isolation, Report ONWI-65 (November 1979). CROFP-1976

A. G. Croff, An Evaluation of Options Relative to Fixation and Disposel of ${ }^{14} \mathrm{C}$-Cont aminated $\mathrm{CO}_{2}$ as $\mathrm{CaCO}_{3}$, Oak Ridge National Laboratory Report ORNL/TM-5171 (1976).

CROFF- 1980

A. G. Croff and C. W. Alexander, Decay Characteristics of Once-Through LWR and LMFBR Spent Fuels, High Level Wastes, and Fuel-Assembly Structural Material Wastes, Oak Ridge National Laboratory Repurt ORNL/TM-7431 (1980). 
DE

S. K. De, N. S. S. Fao, C. M. Tripathi, and C. Rai, Retention of Iodide by Soll Clays, Ind. J. Agric. Chem. 4,43 (1971).

DEAN

J. A. Dean, Ed., Lange's Handbook of Chemistry, 12th Ed", McGraw-Hill Company, New York (1979).

DELDEBBIO

J. A. Del Debbio, Laboratory Evaluation of Zeolite Molecular Sieve 3A for Adsorption of Tritiated Vater Vapor from HTGR Fuel Reprocessing off-Gas, Allied Chemical Corporation, Idaho Chemical Programs-Operations off Ice, U.S. Dept. of Energy Report ICP-1137 (April 1978).

DIAMOND

H. Diamond and S. Fried, Immobilization of Tritium by Incorporation into Polyvinyl Chloride: Final Report, Argonne National Laboratory, unpublished information (October 12, 1981).

DOE 5480.1

DOE Order 5480.1, Chapter iII, Chg. 3 (May 1, 1981).

DOE 5820

DOE Order 5820, Radioactive Waste Management, Draft (January 13, 1983).

DOE/EIS-0046D

Management of Commerclally Generated Radioactive Waste, Draft

Environmental Impact Statement, U.S. Dept . of Energy Report DOE/EIS-0046-D (Apr11 1979).

EOE/EIS-0046F-4.11

Once-Through-Cycle Wastes, Final Environmental Impact Statement, Management of Commercially Generated Radioactive Waste, U.S. Dept. of Energy, Vol. 1, p. 4.11 (October 1980).

DOE/EIS-0046F-5.3

Description of the Conceptual Geologic Repository Facilities, Final

Environmental Impact Statement, Management of Commerclally Generated Radioactive Waste, U.S. Dept. of Energy, Vol. 1, Section 5.3 (October 1980).

DOE/ET-0028

Krypton Storage, Technology for Commercial Radioactive Waste Management, U.S. Dept. of Energy Report DOE/ET-0028, Vo1. 3, PP. 5.6.1-5.6.23 (May 1979).

DOE/NE-0015

Low-Level Radioactive Waste Policy Act Report, Response to Public Law 96-573, U.S. Dept. of Energy Report DOE/NE-0015 (1981).

DUE/NWTS-15

Proceedings of the 1981 National Waste Terminal Storage Program

Information Meeting, U.S. Dept. of Energy Report DOE/NWTS-15

(November 1981) 
DOE/NWTS-19

Interim Performance Specifications for Geologic Disposal of Haste Forms,

U.S. Dept. of Energy Report DOE/NWTS-19 (In preparation).

DOE/NWTS-20

Interim Performance Specifications for Geologic Disposal of Waste

Packages, U.S. Dept. of Energy Report DOE/NWTS-20 (in preparation).

DOE/NWTS-33(1)

NWTS Program Criterla for Mined Geologic Disposal of Nuclear Waste,

U.S. Dept. of Energy Report DOE/NWTS-33(1) (April 1981).

DOE/NWTS-33(2)

NWTS Program Criteria for Mined Geologic Disposal of Nuclear Waste - Site

Performance Criteria, U.S. Dept. of Energy Report DOE/NWTS-33(2)

(Feb. 1981).

DOE/NWTS-33(3)

NWTS Program Criteria for Mined Geologic Disposal of Nuclear Waste -

Repository Performance Criteria, U.S. Dept. of Energy Report

DOE/NWTS-33(3) (in preparation).

DDE/NWTS-33(4)

NWTS Program Criterla for Mined Geologic Disposal of IJuclear Waste -

Waste Package Functional Requirements and Performance Criteria,

U.S. Dept . of Energy Report DOE/NWTS-33(4) (in preparat1on).

DP-CFP-78-121

Design Integration Study Spent LWR Fuel Recycle Complex, Conceptual

Design Case A-1, Separated Streams, E. I. du Pont de Nemours \& Co.,

Inc., Savannah RIver Laboratory Report DP-CFP-78-121 (November 1978).

DUNSTER

H. J. Dunster and B. F. Warner, The Disposal of Noble Gas F1ssion Products

from the Reprocessing of Nuclear Fuel, United King dom Atomic Energy

Author1ty, Harwe11, England, AHSB (RP) R-101 (January 1970).

DUVAL

C. Duval, Inorganic Thermogravimetric Analysis, 2nd Edition, Elsevier

Publishing Company, New York (1963).

EDLING

D. A. Edling and J. F. Griffin, Certification of ERDA Contractors

Packaging with Respect to Compliance with DOT Specification 7A

Performance Requirements, Monsanto Research Corportation, Mound

Laboratory, U.S. ERDA Report MLM-2228 (June 1975).

E.LLIS

R. E. E111s, J. E. Lentz, M. L. Rogers, and C. J. Sienkiewicz, Elinal

Report: Development of Combined Electrolysis Catalyt1c Exchange,

Monsanto Research Corporation, Mound Facllity, U.S. Dept. of Energy

Report MLM-2952 (June 1982). 
EMEIJITY

L. A. Emelity, C. W. Christenson, and J. J. Wanner, Tritium Loss from Coated Cement Paste Blocks, Los Alamos Scientific Laboratory, U.S. Atomic Energy Commission Refort LA-DC-12740 (1971).

EMERSON

E. L. Emerson, The Information Data Bases at the Transportation Technology Center, Proc. Symp. on Waste Management, Tucson, AR, March 8:-11, 1981, R. G. Post and M. E. Wacks, Eds., Arizona Board of Regent s, Vol. 1, pp. 367-374 (1982).

ERDA 76-43A

Interim Storage of Solid Non-High-Level Wastes, Alternatives for Managing Wastes from Reactors and Post-Fission Operations in the LWR Fuel Cycle, Section 20.0, U.S. ERDA Report ERDA 76-43 (May 1976).

ERDA 76-43B

Storage in Deep Continental Geologic Formations, in Alternatives for Managing Wastes from Reactors and Post-Fission operations in the LWR Fuel Cycle, Section 24.2, U.S. ERDA Report ERDA 76-43 (May 1976).

ERDA $77-42$

Alternatives for Long-Term Management of Defense High-Level Radioactive Waste - Savannah River Plant, U.S. ERDA Report ERDA 77-42 (May 1977).

ERDA $77-44$

Alternatives for Long-Term Management of Defense High-Level Radioactive Waste - Hanford Reservations, U.S. ERDA Report ERDA 77-44 (September 1977).

EVANS

A. G. Evans, W. E. Prout, J. T. Bur':ner, and M. R. Buckner, Management of Radioactive Waste Gases from the Nuclear Fuel Cycle--Volume I: Comparison of Alternatives, E. I. du Pont de Nemours \& Co., Savannah River Labor atory Report NUREG/CR-1546, Vol. J (December 1980).

FEDOROV

V. A. Fedorov, A. M. Robov, I. I. Shmyd'ko, N. A. Vorontsova, and

V. E. Mironov, Interaction of Alkaline Earth Element Ions with Nitrate Ions in Aqueous Solutions, Russ. J. Inorg. Chem. 19, 950 (1974).

FEDREG 10218

Requirements for Transportation of Radioactive Materials, U. S. Dept. of Transportation, Federal Register, Vol. 48, No. 48, p. 10218, Thursciay, March 10, 1983.

\section{FERGUSON}

D. E. Ferguson, Chemical Technology Division Progress Report for the Period April 1, 1979 - March 31, 1981, Section 3.7, Carbon-14 Immobilization, Oak Ridge National Labsratory Report ORNL-5757 (1981). 
FOSTER-1975A

B. A. Foster and D. T. Pence, An Evaluation of High Pressure Steel Cylinders for Emission Product Noble Gas Storage, Idaho National Engineering Laboratory, Idaho Falls, Idaho, U.S. ERDA Report ICP-1044 (February 1975).

FOSTER-1975B

B. A. Foster, D. T. Pence, and B. A. St aples, Long Term Storage Techniques for $85 \mathrm{Kr}$, Proc. 13th AEC Air Cleaning Conf., 1974, U.S. Dept of Energy Report CONF-740807, Vol. 1, p. 293 (March 1975).

FRAENKFI

D. Fraenkel and J. Shabtai, Encapsuiation of zydrogen in Molecular Sieve Zeolites, J. Am. Chem. Soc. 99, 7074-7076 (1977).

FRANZ-1975

$\therefore$ A. Franz and L. L. Burger, Polymeric Media for Tritium Fixation, Battelle Pacific Northwest Laboratories Report BNWL-B-430, Richland, WA (May 1975).

FRANZ-1976

J. A. Franz and L. L. Burger, Polymeric Media for Tritium Fixation, Battelle Pacific Northwest Laboratories Peport BNWL-B-430, SUPI, Richland, WA (February 1976).

FUI.LAM

H. T. Ful lan and W. E. Skiens, Evaluation of Ceramic and Polymeric Macerials for Use in Engineered Barrier Systems, Scientific Basis for Nuclear haste Management, J.G. Moore, Ed., Plenum Press, New York, vol. 3, p. 531 (1981).

GALPIN

F. L. Galpin, The U.S. Environmental Protsction Agency's Program for the Development of Low Level Radioactive Waste Disposal Standards, Proc. Fourth Annual Participant's Information Meeting, DOE Low-Level-Waste Management Progran, Denver, Co, August 31-September 2, 1982, Oak Ridge National Laboratory Report ORNL/NFW 82/18 (October 1982).

GARRELS

R. M. Garrels and C. L. Christ, Solutions, Minerals, and Equilibria, Harper and Row Publishers, New York (1965).

GHOVANLOU

A. Ghovanlou, L. Ettlinger, A. Deagazio, and N. Lord, Analysis of Nuclear Waste Disposal and Strategies for Facilities Deploymenc, Appendix A, Technological Options, Mitre Corporation Report MTR-80W88 (April 1980). GLASEL

J. A. Glasel, Nuclear Magnetic Resonance Studies on Water and Ice, in Water, A Comprehensive Treatise, Vol. 1: The Physics and Physical Chenistry of Water, Flex Franks, Ed., Plenum Press, New York, p. 215 (1972).

GMELIN-1960

Gmel in Handbuch der Anorganischen Chemie, Barium Erganzungsband (Systemnummer 30) (1960). 
GMELIN-1961

Gmel in Handbuch der Anorganischen Chemie, Calcium (System-nummer 28) (1961).

GONTARZ-1974

2. Gontarz and A. Gorski, Transformation of Oxygen Iodine Species in Solid, Phase I. Effect of Counterions on the Thermal Decomposition of Iodates, Rocz. Chern. 48, 2091 (1974).

GONTARZ-1980

Z. Gontarz and A. Gorski, Studies on Transformation of Oxygen Iodine Species in Solid, Phase VII. Influence on Counter Ions with Medium Electronegativity Force Values on Decomposition and Reactivity of Iodates, Pol. J. Chem. 54, 1363 (1980).

GRAY-1978

W. J. Gray and G. L. Tingey, Krypton Dissolution in Low Density Glass, Nuclear Waste Management Quarterly Progress Report, January-March 1978, A. M. Platt and J. A. Powell, Compilers, Pacific Northwest Laboratory Report PNL-2378-1 (August 1978).

GRAY-1979

W. J. Gray, G. L. Tingey, and K. R. Wheeler, Krypton Dissolution in Low Density Glass, Nuclear Waste Management Quarterly Progress Report, July-September 1978, A. N. Platt and J. A. Powell, Compilers, Pacific Northwest Laboratory Report PNL-2378-3 (January 1979).

GRIMES

W. R. Grimes, E. C. Hampson, D. J. Larkins, J. O. Skolrud, and

R. W. Benjamin, An Evaluation of Retention and Disposal Options for Tritium in Fuel Reprocessing, Oak Ridge National. Laboratory Report ORNL/TM-8261 (August 1982).

HAAG-1981A

G. L. Haag, Carbon-14 Immobilization Via the $\mathrm{CO}_{2}-\mathrm{Ba}(\mathrm{OH})_{2}$ Hydrate Gas-Solid keaction, Proc. 16th DOE Nuclear Air Cleaning Conference, San Diego, CA, October 1980, M. W. First, Ed., U.S. Dept, of Energy Report CONF-801038, p. 1095 (1981).

HAAG-1981 B

G. L. Haag, Carbon-14 Immobilization Via the $\mathrm{CO}_{2}-\mathrm{Ba}(\mathrm{OH})_{2}$ Hydrate Gas-Solid Reaction, Oak Ridge National Laboratory Report ORNL-7693 (1981).

HAAG- 1983

G. L. Haag, J. W. Nehls, Jr., and G, C. Young, Carbon-14 Immobilization $\mathrm{Via}$ the $\mathrm{Ba}(\mathrm{OH})_{2} \cdot 8 \mathrm{H}_{2} \mathrm{O}$ Process, Proc. 17 th DOE Nuclear Air Cleaning Conf., M. W. First, Ed., U.S. Dept. of Energy Report CONF-820833, Vo1.. 1, p. 431 (February 1983). 
HALL

N. E. Hall and G. N. Ward, Tritium Control by Water Recycle in a Nuclear Fuel Reprocessing Plant, General Electric Co., San Jose, CA, prepared for Battelle Pacific Northwest Laboratories for the U.S. ERDA, Report NEDG-11342 (June 1975).

HAMID

A. Hamid and B. P. Warkent1n, Retention of I-131 Used as Tracer in WaterMoveme.1t Studies, Soil Sci. 104, 279 (1967).

HAQ

2. Haq, G. M. Bancroft, W. S. Fyle, G. Bird, and V. J. Lopata, Sorption of Iodide on Copper, Environ. Sc1. Technol. 14, 1106 (1980).

HAR TMANN

i. Hartmann and H. Brucher, Alternative Concepts for Storage and Disposal of Tritiated Waste Water Arising from Reprocessing, Management of Gaseous Wastes from Nuclear Facllitles, IAEA Report IAEA-SM-245/6, p. 615 (1980).

HATTA

H. Hatta and H. Ono, Experimental Study of Leaching of Radioactive Materials from Radwaste Solidifled in Cement by Seawater, Part II. Centeral Research Institute of the Electric Power Industry, Translation from the Japanese, Oak Ridge National Laboratory Report ORNL-TR-4226 (1975).

HELMUTH

R. A. Helmuth, F. M. Miller, T. R. O'Connor, and N. R. Greening, Cement, Ki rk-Othmer Encyclopedia of Chemical Technology, H. F. Mark, Executive Ed., John Wiley and Sons, Inc., New York, Vol. 5, p. 163 (1979).

HENRICH

E. Henrich and $H$. Schmieder, The Concentration of Tritium in the Aqueous and Solld Waste of LWR Fuel Reprocessing Plants, Management of Gaseous Wastes from Nuclear Facllities, IAEA-SM-245/15, International Atomic Energy Agency, Vienna (1980).

HOLCOMB

W. F. Holcomb, A History of Ocean D1sposal of Packaged Low-Level Radioactive Waste, Nucl. Saf. 23(2) (March-April 1982).

HOLLADAY- 1978

D. W. Holladay and G. L. Haag, Removal of ${ }^{14} \mathrm{C}$-Contamt nated $\mathrm{CO}_{2}$ f rom S1mulat ?d LWR Fuel Reprocessing Off-Gas by Utilizing the Reaction Between $\mathrm{CO}_{2}$ and Alkaline Hydroxides In E1ther Slurry or Soll d Forms, Proc. 15th DOE Nuclear A1r Cleaning Conf., Boston, MA, August 1978 , M. W. F1rst, Ed., p. 547 (1979).

HOLLADAY-1979

D. W. Holladay, A L1terature Survey: Methods for the Removal of Iodine Spectes from Oft-Gases and LIquid Waste Streams of Nuclear Power and Nuclear Fuel Reprocessing Plants, with Emphasis on Soldd Sorbents, Dak R1dge National Laboratory Report ORNL/TM-6350 (January 1979). 
HOLLAND

W. D. Holland, A. H. Shah, A. F. Kaiser, and J. C. McGee, Experimental Studies Concerning the Drying of Voloxidizer Off-Gases, Chemical Engineering Dept., Tennessee Technological University, Oak Ridge National Laboratory Report ORNL/Sub-7164/1 (July 1981).

HONIG

E. P. Honig and J. H. Th. Hengst, Points of Zero Charge of Inorganic Precipitates, J. Colloid Interface Sci. 29 (1969).

HOOKER

R. L. Hooker, Intermediate Depth Burial, Proc. Third Annual Information Meeting DOE Low-Level Waste Management Program, November 4-6, 1981, New Orleans, D. E. Large et al., Compilers, Oak Ridge National Laboratory Report ORNL/NFW-81/34, p. 477 (December 1981).

HUNTER

P. H. Hunter, The Criteria and Technical Concept for Demonstrating Greater Confinement Disposal of Radioactive Wastes at Arid Western Sites, Proc. Third Annual In formation Meeting DOE Low-Level Waste Management Program, New Orleans, November 4-6, 1981, D. E. Large et al., Compilers, Oak Ridge National Laboratory Report ORNL/NFW-81/34 (December 1981).

IKEDA

N. Ikeda and K. Tanaka, Column Chromacographic Separation of Radioactive

Tellurate, Tellurite, Iodide, and Iodate by Active Charcoal,

J. Chromatagr. 114,389 (1975).

JACOBS

D. G. Jacobs, Behavior of Radioactive Gases Discharged into the Ground, Nuc1. Saf. 2, 175-178 (1967).

JEFFERSON-1976

R. M. Jefferson and L. L. Bonzon, Available Packaging and Transportation Systems, Proc. Int. Symp. on the Management of Wastes from the LWR Fuel Cycle, Denver, Co, July 11-16, 1976, CONF-760701, p. 448 (1976).

JEFFERSON-1982

R. N. Jefferson, Sandia National Laboratories, personal communication to

L. E. Trevorrow, August 1982 .

JONE S-1973A

A. L. Jones, G. A. Madigan, and I. R. Wilson, The Dissolution and Growth of Barium Iodate Crystals: I. Rates of Dissolution and Growth, J. Cryst. Growth 20, 93 (1973).

JONES-1973B

A. L. Jones, G. A. Madigan, and I. R. Wilson, The Dissolution and Growth of Barium Iodate Crystals: II. The Equilibrium Solubility of Barium Iodate, J. Cryst. Growth 20, 99 (1973). 
JUBIN

R. T. Jubin, A Literature Survey of Methods to Remove Iodine from off-Gas Streams Using Solid Sorbents, 0ak Ridge National Laboratory Report ORNL/TM-6607 (March 1979).

KAISER

A National Waste Terminal Storage Repository In a Bedded Salt Formation for Spent Unreprocessed Fuel, prepared for U.S. Dept. of Energy, Dak RIdge Operations, Kalse: Englneers Report 78-57-RE (December 1978).

KAUFMAN

W. J. Kaufinan and G. T. Or lob, An Evaluation of Ground-Water Tracers,

Am. Geophys. Union 37, 297 (1956).

KING

L. G. King, Mathematical Models for Underground Injection of Gaseous Wastes into the Vadose Zone, Battelle Northwest Laboratory Report BNWL-945 (December 1958).

KLETT-1981

R. D. Klett, Ed., Krypton-85 Disposal Program Conceptual Design Fhase: Final Report, Sandia National Laboratories Report SAND81-1957 (November 1981).

KLETT-1 982

R. D. Klett, Sandia National Laboratories, personal communication to

L. Trevor row (Novem ber 1982).

KNECHT-1 977

D. A. Knecht, An Evaluation of Methods for Immobilizing Krypton-85,

Idaho Chemical Programs Operations of fice, Allied Chemical Corp. Report ICP-1125 (July 1977).

KNECHT-1 981

D. Knecht, Exxon Nuclear Idaho Co., Inc., private communication to

L. Trevorrow (September 1981).

KULLEN

B. J. Kullen, L. E. Trevor row, and M. J. Steind ler, Tritlum and Noble-Gas F1ssion Products in the Nuclear Fuel Cycle: II. Fuel Reprocessing Plants, Argonne National Laboratory Report ANL-8135 (March 1975).

LAKNER

J. F. Lakner, G. A. Morris, and S. Copper, Tritlum Storage in Holecular S leves, Lawrence L1vermore Laboratory, UCRL-Preprint 86037 (October 1981).

\section{LAMBERGER}

P. H. Lamberger and M. L. Rogers, Tritlum Waste Control, October 1981March 1982, Monsanto Research Corp., Mound Laboratory Report MLM-2969

(August 1982). 
LARGE-1981

D. E. Large, R. S. Lowrie, L. E. Stratton, and D. G. Jacobs, Compilers, Proceedings of the Third Annual Information Meeting DOE Low-Level Waste Management Program, New Orleans, November 4-6, 1981, Oak Ridge National Laboratory Report ofNL/NFW-81/34 (Decenber 1981).

LARGE-1982

D. E. Large, L. J. Mezga, L. E. Stratton, and R. R. Rose, Compilers,

Proceedings of the Fourth Annual Participants Information Meeting, DOE Low-Level Waste Management Program, Denver, $\mathrm{CO}$, August 31September 2, 1982, Oak Ridge National Laboratory Report ORNL/NFW-82/18 (October 1982).

LEV IN- 1981

G. B. Levin, Lo:y-Level Radioactive Waste Management in the U.S.: A Proving Ground, Nucl. News (Finsdale, IL) 24(10), 72-76 (1981).

LEV IN- 1982

G. B. Levin, EG\&G Idaho, Inc., personal communication to L. Trevorrow (October 1982).

LINKE

W. F. Linke, Solubilities: Inorganic and Meral-organic Compounds, 4tr: Ed., D. Van Nostrand Company, Inc., New York (1958).

L.IPTAY

G. Liptay, Ed., Atlas of Thermedynamic Curves, Number $20\left(\mathrm{CaCO}_{3}\right)$, Hayden and Sons, Ltd., New York (1971).

\section{LITTLE}

D. K. Little, R. S. Eby, J. L. Norton, J. L. Patton, R. M. Schultz, and J. M. Varagona, Noble Gas Removal and Concentration by Combining Fluorocarbon Absorption and Adsorption Technologies, Proc. 17th

DOE Nuclear Air Cleaning Conf., Eenver, Co, August 2-5, pp. 694-717, (February 1983).

L.OKKEN

R. O. Lokken, A Review of Radioactive Waste Immobilization in Concrete, Pacific Northwest Laboratory Report PNL-2654 (1978).

L.YTLE

J. M. Lytle and G. L. Tingey, Rrypton Release Studies, Nuclear Waste Management Semiannual progress Report April 1982 through September 1982, T. D. Chikalla and J. A. Powe11, Compilers, Pacific Northwest Laboratory Report PNL-4250-2 (December 1982).

MCCALIS

D. L. McCal1, Hanford Radioactive Solid Waste Packaging, Storage, and

Disposal Requirements, Rockwell International, Rockwell Hanford Operation, Richland, WA, U.S. Dept. of Energy Report RHO-MA 222 (May 1980). 
MCCLANAHAN

E. D. McClanahan, Battelle Pacific Northwest Laboratories, private

communication to J. Christian, Exxon Nuclear Id aiho Corp. (1982).

MCKAY

H. A. C. McKay, Tritium Immobilization, Eur. Appl. Res. Rept., Nucl. Sci. Technol. $1(3), 599-711$ (1979).

MCMANUS

G. J. McManus, F. A. Duce, S. J. Fernandez, and L. P. Murphy, A Model of Iodine-129 Process Distribution in a Nuclear Fuel Reprocessing Plant, Exxon Nuclear Idaho Co., inc., U.S. Dept. of Energy Report ENICO-1108 (April 1982).

MAGNANI

N. J. Magnani and T. W. Braithwaite, Corrosion-Resistant Metallic Canisters for Nuclear Waste Isolation, Scientific Basis for Nuclear Waste Management, C. J. M. Northrup, Jr., Ed., Plenum Press, New York, Vol. 2, pp. 377-384 (1980).

MAILEN

J. C. Mailen and L. M. Toth, Chemistry of Volatile Fission Product

Element, Light Wster Ruactor Nuclear Fuel Cycle, R. G. Wymer and

B. L. Vondra, Eds., CRC Press Inc., Boca Raton, FL, p. 163 (1981).

MARTIN

M. J. Martin, Nuclear Decay Data for Selected Radionuclides, Oak Ridge National Laboratory Report ORNL-5114 (April 1976).

MASON-1977

A. S. Mason, J. Geophys. Res. 82, 5913 (1977).

MASON-1979

A. S. Mason and H. G. Ostlund, Atmospheric HT and HTO: V. Distribution and Large-Scale Circulation, Proc. IAEA/NEA Symp. on Behavior of Trit ium in the Environment, San Francisco, CA, October 1978, IAEA (1979).

MATSUZURU

H. Matsuzuru, N. Moriyana, and A. Ito, Leaching Behavior of Tritium from a Hardened Cement Paste, Ann. Nucl. Energy 6, 417-23 (1979).

MELL INGER

P. J. Mellinger, G. R. Hoenes, L. W. Brackenbuah, and J. Greenborg,

$85_{\mathrm{Kr}}$ Management Trade-0ffs: A Perspective to Toral Radiation Dose Comnitment, Pacific Northwest Laboratory Report PNL-3176 (Janua: 1980).

MERRIMAN-1980

J. R. Merriman, M. J. Stephenson, B. E. Kanak, and D. K. Little, Removal of Noble Gases by Selective Absorption, Proc. Int. Symp. on Management of Gaseous Wastes from Nuclear Facilities, IAEA Report IAEA-SM-245/53, Vienna (1980). 
MERRIMAN- 1982

J. R. Merriman, Oak Ridge National Laboratory, personal communication to M. J. Steindler 1982 .

MERSHAD-1977A

E. A. Mershad, w. W. Thomasson, and J. J. Dauby, Tritiated Liquid Waste Packaging, Monsanto Research Corporation, Mound Laboratory, U.S. ERDA Report MLM-2440 (August 1977).

MERSHAD-1977B

E. A. Mershad, W. W. Thomasson, and J. J. Dauby, Packaging of TritiumContaminated Liquid Waste, Nuci. Technol. 32, 53-59 (1977).

MiEK

R. J. Meyer, Gmelia Handbuch der Anorganischem Chemie, $\mathrm{Ag}[\mathrm{B} 2]$, Section 8.2 (AgI), p. $300(\overline{1972)}$.

MEZGA

L. J. Mezga, Overview of Milestone E Activities, Greater Confinement than Shallow Land Burial, in Proc. of the Third Annual Information Meeting DOE Low-Level Waste Management Program, New Orleans, November 4-6, 1981 , pp. 467-522 (1981).

MILLER

N. E. Miller, A Survey of Packaging for Solidified Low-Level Waste, Battelle Columbus Laboratories Report for U.S. EPA, PB $\cdot 295038$

(September 1978).

MOCK

J. E. Mock et al., Crystallization of the Rare-Gas Clathrates, Ind. Eng. Chem. 53, $1007(1961)$.

MONSON

P. R. Monson, Krypton Retention on Solid Adsorbents, E. I. du Font de

Nemours and Co., Savannah River Laboratory Report DP-1615 (January 1982). MOORE

J. G. Moore, H. E. Devaney, H. W. Godbee, M. T. Morgan, G. D. Rogers, C. Williams, and E. Newman, The Fixation of Radioactive Wastes in Concretes and Cementious Grouts, Nuclear Mescing, Basti, Switzerlanc', Oc zober 3, 1978, CONF-781004-5 (1978).

MORGAN-1979

K. T. Morgan, J. G. Moore, H. E. Devaney, G. C. Rogers, C. Williams, and E. Newman, The Disposal of Iodine-129, Scientific Basis for Nuclear Waste Management, G.J.McCarthy, Ed., Plenum Press, New York, Vol. 1, pp. 453-459 (1979).

MUDRA

P. J. Mudia and B. L. Schmaltz, An Appraisal of Gaseous Waste Disposal into the Lithosphere at the NRTS, Idaho, Idaho Operations office, Idaho Fal1s, U.S. Atomic Energy Commission Report IDO-12024 (September 1965). 
MUELLER

W. M. Mueller, J. P. Blackledge, and G. G. Libowitz, Eds., Metal Hydrides, Academic Press, New York (1968).

MULLER

M. E. Mul ler, Conceptual Design of an Emergency Tritium Clean-Up System, Los Alamos Scient1fic Laboratory Report LA-7136-MS (January 1978).

MURPHY-1 977

L. P. Murphy, B. A. Staples, and T. R. Thomas, The Development of $\mathrm{Ag}^{\circ} \mathrm{Z}$ for Bulk 129 I Removai from Nuclear Fuel Reprocessing P1ants and PbX for

129 I Storage, Idaho Chemical Programs Operations office, Allied Chemical Corp. Report ICP-1135 (1977).

MURPHY-1983

L. P. Murphy, S. J. Fernandez, and G. J. McManus, Continuous Radioiodine Cleanup Filter Efficiency Monitor, Exxon Nuclear Idaho Co., Inc. Keport ENT.CO-1121 (January 1983).

NAGATA

P. K. Nagata and T. P. Pinchback, Materials Screening Tests for the Krypton-85 Storage Development Program--Final Report, Exxon Nuclear Idaho Co., Inc. Report ENICO-1081 (April 198i).

NEA

Radiological Significance and Management of Tritium, Carbon-14, Krypton-85, anci Iodine-129, Nuclear Energy Agency, Organization for Economic Cooperation and Development, report by an NEA Group of Experts, OECD, Par1s, I'rance (1980).

NEAL

C. Neal and V. W. Truesdale, The Sorption of Iodate and Iodide by Riverine Sediments: Its Implications to Dilution Gauging and Hydrochemistry of Iodine, J. Hydrol. 31, 28i (1976).

N/DFT-35

Interim Iroduct Specifications and Data Requirements for Geologic Isolaticin of Defense High-Level Waste Forms, Office of Nuclear Wa ste Isolation, Battelle Project Management Division, prepared for U. S. Dept. ố Energy, Report N/DFT-35 (Feb. 1982).

NOTZ-1 980A

K. J. Notz, D. W. Holladay, C. W. Forsberg, and G. L. Haag, Processes for the Control of $14 \mathrm{CO}_{2}$ Du.ring Reprocessing, Oak Ridge National Laboratory Report ORNL/TM-i/338 (1980).

NOT2-1980B

K. J. Notz, D. W. Holladay, C. W. Forsberg, and G. L. Haag, Processes for the Control of $14 \mathrm{CO}_{2}$ IJuring Reprocessing, Proc. Int. Symp. on Management of Gaseous Wastes from Nuclear Facilities, Vienna, February 1980, IAEA Report IAEA-SM-245/29, p. 191 (1980). 
NOWAK

E. J. Nowak, Composite Backf1ll Materlals for Radioactive Waste Isolation by Deep Burial in Salt, Sclentific Basis for Nuclear Waste Management, J. G. Morre, Ed., Plenum Press, New York, Vol. 3, p. 545 (1981).

NUCLSAF

Radloactive Materlal Released from Nuclear Power Plants in 1978, Nucl. Saf. 22(6), 782-788 (1981).

NUREG-0217

NRC Task Force Report on Review of the Federal/state Program for: Regulation of Commercial Low-Level Radioactive Waste Burial Grounds, Office of Nuclear Material Safety and Office of State Programs, U.S. Nuclear Regulatory Commission Report NUREG-0217 (March 197\%).

NUREG -0383

Directory of Certificates of Compliance for Radioactive Materlals Packages, Summary Report of NRC Approved Packages, U.S. Nuclear Regulatory Commission Report NUREG-0383, Vo1s. I\& 2, December 1977;

Rev. 1, November 1978; Rev. 2, Oc tober 1979.

NUREG-0782

Draft Fnvironmental Impact Statement on 10 CFR Part 61 "LIcensing Requirements for Land DIsposal of Radioactive Waste", U.S. Nuclear Regulatory Commission Report NUREG-0782, Vols. 1, 2, 3, September 1981.

NWN

House Passes Moratorlum on EPA Ocean Radwaste Permit Approval, Nucl. Waste News, p. 148 (September 23, 1982).

ONO

F. Ono, M. Nakazawa, Y. Takahash 1 , and M. Kanno, D1strtbution

Equilibrium of Tritium Between Adsorbed Water on Molecular sieves $5 \mathrm{~A}$ and Environmental Water, J. Nuc l. Sc1. Technol. 17, 721 (1980).

ONWI-20

J. Phillips, F. Felzollahi, R. Martineit, W. Bell, and R. Stoulcy, A Waste Inventory Report for Reactor and Fuel-Fabrication Facility Wastes, Battelle office of Nuclear Waste Isolation Report. ONWI-20 (March 1979).

PARSONS

Des1gn Documentation--Krypton Encapsulation Preconceptual Design,

The Ralph M. Parsons Company Report 6154-3-1, Pasadena, CA (July 1981).

PARTRIDGE

J. A. Partridge and G. P. Bosuego, Waste Management of Mercuric Nitrate Off-Gas Scrubber Solution: A Laboratory Study, Hanford Eng1neering Development Laboratory Report HEDL-TME-79-11 (July 1979).

PATCH

K. D. Patch, R. P. Hart, and W. A. Schumacher, Analysis of Barlum Hydroxide and Calcium iydroxide Slurry Carbonation Reactors, Oak Ridge National Laboratory Report ORNL/MIT-300, May 1980. 
PENCE-1974

D. T. Pence and B. A. Staples, Solid Adsorbents for Collection and Storage of Iodine-129 from Reprocessing Plants, Proc. 13th AEC Air Cleaning Conference, M. W. First, Ed., CONF-740807, Vol. 2, p. 758 (1974).

PENCE-1981A

D. T. Fence, Critical Review of Noble Gas Recovery and Treatment Systeiss,

Nuc 1. Saf. 22(6) (November-Derember 1981).

PENCE-1981B

D. T. Pence and B. E. Kirstein, A Design and Cost Estimate for the SRL

Integrated Hot off Gas Facility Using Selective Adsorption, Science

Applications, Inc. Report SAI-509991R (July 1981).

PENZHORN-1980A

R. D. Penzhorn, Long-Term Storage of $85 \mathrm{Kr}$ in Zeolite 5A, Proc.

16th DOE Air-Cleaning Conf., CONF-801038, Vol. 2 pp. 1047-1058 (October

1980).

PENZHORN-1980B

R. D. Penzhorn, P. Schuster, H. E. Noppe1, and L. M. He $1 \mathrm{lw}$. Storage of Krypton-85 in Zeolites, Management hif Gaseous Wastes from Nuclear Facilities, IAEA Report IAEA-SM-245/10, pp. 291-300

(December 1980).

PENZHORN-1981

R. D. Penzhorn, Discussion of the paper, Critical Review of Noble Gas

Systems, by D. T. Pence, Proc. 16th DOE Nuclear Air Cleaning Conf.,

1980, CONF-801038, p. $1015(1981)$.

PENZHORN-1982

R. D. Penzhorn, Kernforschungszentrum Karlsruhe GmbH., Karlsruhe, Germany, private communication to J. D. Christian, Exxon Nuclear Idaho, Co. Inc. (1982).

PERFTT.

F. J. Peretz, M. E. Muller, and P. Y. Pan, Krypton-85 Hydrofracture

Engineering Feasibility and Safety Evaluation, Oak Ridge National

Laboratory Report ORNL/ENG/TM-22 (JuTy i981).

PERKINS

B. L. Perkins, Disposal of Liquid Rarioactive Wastes through Wells or

Shefts, Los Al amos National Laboratory Report LA-9142-MS (January 1982).

PHILLIPS

J. E. Phillips and C. E. Easterly, Sources of Tritium, Nucl. Saf. 22(5)

(September-October 1981 ).

\section{PINCHBACK-1979A}

T. R. Pinchback and D. A. Knecht, The Development of Process and Storage Materials Suitable for Krypton-85 Waste Management, Scientific Basis for Nuclear Waste Management, G. J. McCarthy, Ed., Plenum Press, Nev York Vol. 1 (1979). 
PINCHBACK-1979B

T. R. Pinchback, Materials Screening Tests for the Krypton-85 Storage

Development Program, EG\&G Idaho Inc., Idaho National Engineering

Laboratory, U.S. Dept. of Energy Repurt TREE-1291 (January 1979).

PI TMAN

S. G. Pitman, B. Griggs, R. P. Elmore, Evaluation of Metallic Materials

for Use in Engineered Barrier Systems, Scientific Basis for Nuclear

Waste Management, J. G. Moore, Ed., Plenum Press, New York, Vol. 3.

p. 523 (1981).

PL-96-573

Low-Level Radioactive Waste Policy Act, 96th Congress, December 22, 1980.

PLATT-1978

A. M. Platt and J. A. Powell, Nuclear Waste Maragement Quarterly Progress Report January-March 1978, Pacific Northwest Laboratory Report PNL-2378-1 (August 1978).

PLATT-1979A

A. M. Platt and J. A. Powe1l, Nuclear Waste Management Quarterly Progress Report October-December 1978, Section 5, Carbon-14 and Iodine-129

Fixation, Pacific Northwest Laboratory Report PNL-2378-4 (1979).

PLATT-1979B

A. M. Platt and J. A. Powe11, Nuclear Waste Management Quarterly Progress

Report April-June 1979, Section 5, Carbon-14 and Iodine-129 Fixation,

Pacific Northwest Laboratory Report PNL-3000-2 (1979).

PLATT-1979C

A. M. P1att and J. A. Powe11, Nuclear Waste Management Quarterly Progress Report July-September 1979, Section 5, Carbon-14 and Iodine-129 Fixation, Pacific Northwest Laboratory Report PNL-3000-3 (1979).

PLATT-1980

A. M. Platt and J. A. Powe11, Nuclear Waste Management Quarterly Progress Report April-June 1980, Section 8, Iodine-129 Fixation, Pacific Northwest Laborat ory Report PNL-3000-6 (1980).

PLUNG

D. L. Plung, Ed., Technical Quarterly Progress Report, April-June 1979,

Exxon Nuclear Idaho Co., Inc. Report ENICO-1013 (January 1980). PROUT

W. E. Prout, W. S. Durant, A. G. Evans, M. R. Buckner, and W. V. Wright, Management of Radioactive Waste Gases froin the Nuclear Fuel Cycle, Volume II, Evaluation of Storage/Disposal Alternatives, Savannah River Laboratory, U.S. Nuclear Regulatory Commission Report NUREG/CR-1546, Vol. II.

RADEX

The Radioactive Exchange, February 15, 1982. 
RAJA

M. E. Raja and K. L. Babcok, On the Soil Chemistry of Radio-Iodine, Soil Sci. 91 (1961).

REINIGER

P. Reiniger, Transfer of Iodine in Terrestrial Ecosystems, Compte Rendue

d'une reunion de Specialistes de 1'AEN, Paris, p. 38 (1977).

REIST

P. C. Reist, The Disposal of Waste Radioactive Gases in Porous Underground Media, Nucl. Appl. Technol. 3, 474-480 (August 1967).

RENNER

T. A. Renner and C. C. McPheeters, Tritium and Hydrogen Transport in LMFBR Systems: EBR-II, CRBR, and FFTF, Argonne National Laboratory Report ANL-78-64 (September 1978).

RHO-CD-568

Rockwell International, Commercial Waste Packaging Program--Radioactive Waste Package Acceptance Criteria, U.S. Dept. Of Energy Report RHO-CD-568 (October 1978).

ROGERS

G. C. Rogers, J. G. Moore, and M. T. Morgan, Scrubbing of Iodine from Gas Streams with Mercuric Nitrate-Conversion of Mercuric Iodate to Barium Iodate for Fixation in Concrete, Oak Ridge National Laboratory Report ORNL/TM-7102 (June 1980).

RUTHVEN

D. M. Ruthven, J. S. Devgun, F. H. Tezel, and T. S. Sridhar, Removal of

$\mathrm{Kr}$ from $\mathrm{N}_{2}$ by Selective Adsorption, Proc. 16th DOE Nuclear Air Cleaning

Conf., San Diego, CA, October 1980, CONF-801038, Vol. 1 (October 1980).

SAND80-2384

Program Criteria for Subseabed Disposal of Radioactive Waste: Research Strategies and Review Processes, Sandia National Labortories Re port SAND80-2384 (September 1981).

SCHEELE-1976

R. D. Scheele and L. L. Burger, Zirconium Hydride as a Storage Medium for Tritium, Battelle Pacific Morthwest Laboratories Report BNWL-2083 (July 1976).

SCHEELE-1981

R. D. Scheele and L. L. Burger, Characterization Studies of Iodine-Loaded Silver Zeolites, Pacific Northwest Laboratory Report PNL-SA-9510 (1981).

SCHEE LE- 1982

R. D. Scheele and L. L. Burger, Selection of a Carbon-14 Fixation Form, Pacific Northwest Laboratory Report PNL-4447 (September 1982). 
SHEP PARD

N. F. Sheppard, R. C. Rizo-Patron, and W. H. Sun, Analyois of Stirred-

Tank Carbonation Reactors, Oak Ridge National Laboratory Report

ORNL/MT T-281, November 1978.

SHERWOOD

A. E. Sherwood, Iritium Removal from Alr Streams by Catalytic Oxidation and Water Adsorption, Lawrence LI vermore Laboratory Report UCRL-78173 (June 1976).

\section{SIDGEWICK}

N. W. Sidgewick, The Chemical Elements and Their Compounds, Vol. 1, Oxford Untversity Press, London (1962).

STAPLES-1974

B. A. Staples and D. T. Pence, An Evaluation of Quinol Clathrate for

Fission Product Noble Gas Storage, Idaho Chemlcal Programs Operations offlce, Allied Chemical Corp. Report ICP-1045 (July 1974).

\section{STEARNS}

National Waste Terminal Storage Repository for S1:oring Reprocessing Wastes In a Dome Salt Formation, Stearns-Roger F.nglneering Company, prepared for DOE under contract EY-77-C-05-5367 (January 1979).

STEINDLER-1978

K. J. Steindler et al., Chemical Engineering Division Fuel Cycle Prugram Quarterly Progress Report, October-December 1978, Argonne Nat1onal Laboratory Report ANL-79-29 (January 1980).

STE INDLER-1979A

M. J. Stelndler et al., Chemical Engineering Division Fuel Cycle Program Quarterly Progress Report, January-March 1979, Argonne Nat1onal Laboratory Report ANL-79-45 (January 1980).

\section{STEINDLEK-1979B}

M. J. Steindler et al., Chemical Englneering Division Fuel Cycle Program Quarterly Progress Report, July-September 1979, Argonne National Laboratory Report ANL-79-109 (September 1980).

STEINDLER-1979C

M. J. Steindler et al., Chemical Englneering Division Fuel Cycle Program Quarterly Progress Report, October-December 1979, Argonne National Laboratory Report ANL-80-61 (July 1980).

STEPHEN

H. Stephen and T. Stephen, Solubilities of Inorganic Compounds, Vol. I, Part 1, Pergamon Press, New York (1963).

\section{STEPHENSON-1976}

M. J. Stephenson and R. S. Eby, Development of the FASTER Process for Removing Krypton-85, Carbon-14, and other Contaminants from the off-Gas of Fuel Reprocessing Plants, Proc. $14 \mathrm{th}$ ERDA Alr Cleaning Conf., CONF-760882, Vol, 2, p. 1017 (August 1976). 
STEPHENSON-1977

M. J. Stephenson et al., Selective Absorption P1lot-Plant for

Decontamination of Fuel Reprocessing Plant Off-Gas, Oak Ridge Gaseous Diffusion Plant Report K-1876 (October 1977).

STRACHAN

D. M. Strachan and $\mathrm{H}$. Babad, Iodide and Iodate Sodalites for the LongTerm Storage of Iodine-129, Rockwell International, Rockwell Hanford operations Report RHO-SA-83.

STRICKERT-1978

R. Strickert, A. M. Friedman, and S. Fried, The Sorption of Technetium and Iodine Radiolsotopes by Varlous Minerals, Trans. Am. Nucl. Soc. 28, $365(1978)$.

STRICKERT-1980

R. Strickert, A. M. Friedman, and S. Fried, The Sorption of Technetium and Iodine Radioisotopes by Various Minerals, Nucl. Technol. 49, 253 (1980).

SUGAWARA

K. Sugawara, T. Koyama, and K. Terada, Copreclpil:ation of Iodide Ions by Some Metallic Hydrated Oxldes with Speclal Rejerence to Iodide Accumulation in Bottom Water Layers and in Intersititial Water of Muds in Some Japanese Lakes, J. Earth Sc1. 6, 52 (1958).

TADMOR

J. Tadmor and K. I. Cowser, Underground Disposal of Krypton-85 from Nuclear Fuel Reprocessing Plants, Nucl. Eng. Des. 6, 243-250 (1967).

THAMER-1978

B. J. Thamer, C. M. Minlfeith, and P. J. Macbeth, The Evaluation of Alternatives for the Ultimate Disposal of Krypton-85: Task 1-Compilation of Alternatives, Ford, Bacon \& Davis Utah, Inc., U.S. EPA Report UC-261-01 (Draft) (December 1978).

THAMER-1979

B. J. Thamer, P. J. Macbeth, and D. C. Rich, The Evaluation of Alternatives for the Ultimate Disposal of Krypton-85: Task 2 \& 3--The Evaluation of Storage Techniques and Ultimate Disposal, Ford, Bacon \& Davis Utah, Inc., U.S. EPA Report UC-261-03 (Draft) (May 1979).

THOMAS

T. R. Thomas, B. A. Staples, L. P. Murphy, and J. T. Nichols, Airborne Elemental Iodine Loading Capacities of Metal Zeolites and a Method for Recycling S1lver Zeolite, Idaho Chemf cal Programs Operations office, Aliled Chemical Corp. Report ICP-1119 (Juiy 1977).

TINGEY-1982A

G. L. T1ngey, E. D. McClanahan, R. W. Knoll, R. W. Moss, J. M. Lytle, and N. R. Gordon, Krypton Implantation, Nuclear Waste Management Semt-annual Progress Report, October 1981-March 1982, T. D. Chikalla and J. A. Powe11, Eds., Pacif1c Northwest Laboratory Report PNL-4250-1 (June 1982). 
TINGEY-1982B

G. L. Tingey, E. D. McClanahan, J. M. Lytle, N. R. Gordon, and

R. W. Knoll, Krypton-85 Storage in Sputter-Deposited Amorphous Metals,

Pacific Northwest Laboratory Report PNL-SA-10536 (June 1982).

TREVORROW

L. E. Trevorrow, D. L. Warner, and M. J. Steindler, Considerations

Affecting Deep Nell Disposal of Tritium Bearing Low-Level Aqueous Waste

from Nuclear Fuel Reprocessing Plants, Argonne National Laboratory Report

ANL-76-76 (March 1977).

TURI

P. L. Turi and J. F. Lakner, Hydrogen Encapsulation in a Cs-Exchanged

Type 4A Zeolite, Lawrence Livermore Laboratory Report UCRL-52865

(September 1979).

VANCE

E. R. Vance, D. K. Agrawal, B. E. Scheetz, J. K. Pepin, S. D. Atkinson, and $W$. B. White, Ceramic Phases for Immobilization of $129 \mathrm{I}$, U.S. Dept. of Energy Report DOE/DT/41900-9 (July 1981).

VON AMMON-1978

R. von Ammon, H.-G. Burkhardt, E. Hutter, and G. Neffe, Development of a Cryogenic Krypton-Separation System for the Off-Gas of Reprocessing

Plants, Proc. 15th DOE Nuclear Air Cleaning Conf., Boston, MA,

August $7-10,1978$, p. 640 (1978).

VON AMMON-1980

R. von Ammon and G. Nnittel, Catalytic Reduction of $\mathrm{O}_{2}$ and $\mathrm{NO}_{\mathrm{x}}$ : A

Critical Pretreatmenc Step for thi Cryogenic Retention of Krypton-85,

Proc. of the Management of Gaseous Wastes from Nuclear Facilities Symp.

International Atomic Energy Agency, Vienna, 1980, STI/PUB-561,

p. 229 (1980).

VON AMMON-1981

R. von Ammon, W. Bumiller, E. Hutter, and G. Neffe, Steady State Operation of the First Cryogenic Colum in a Krypton Separation System, Proc.

16th DOE Nuclear Air Cleaning Conf., San Diego, CA, October 1980

(February 1981).

VON AMMON-1983

R. von Ammon, W. Bumiller, E. Hauss, E. Hutter, G. Nesfe, and R. R. Hammer, Formation and Behaviour of Nitric Oxides in a Cryogenic Krypton Separation System and Consequences of Using Air as Process Gas, Proc. 17th DOE

Nuclear Aíf Cleaning Conf., Denver, CC, August 2-5, 1982, Vol. 2,

Pp. 683-693 (February 1983).

WARNECKE

E. Warnecke and S. Ahner, Air-Cooled Krypton-85 Storage Facility with Natural Convection, Management of Gaseous Wastes from Nuclear Facilities, IAEA Report IAEA-SM-245/11, pp. 645-659 (Decender 1980). 
WASH-1279

Directory of Packagings for Transportation of Radioactive Materials, Division of Waste Management and Transportation, U.S. Atomic Energy Commission Report WASH-1279 (October 1973).

WESTERMAN

R. E. Westerman, Developiuent of Structural Engineered Berriers for the Long-Term Containment of Nuclear Waste, Scientific Basis for Nuclear Waste Management, J. G. Moore, Ed., Plenum Press, New York, Vol. 3, P. 515 (1981).

WHEELER

M. L. Wheeler, W. J. Smith, J. L. Warren, and W. J. Whitty, Burial

Grounds, Proc. Int. Symp. on the Management of Wastes from the LWK Fuel Cycle, Denver, Colorado, July 11-16, 1976, CoNF-76-0701, pp. 329-357.

WH ITEHEAD-1973A

D. C. Whi iehead, The Sorption of Iodide by Soils as Influenced by

Equilibrium Conditions and Soil Properties, J. Sci. Food Agric. 25, 547 (1973).

WHITEHEAD-1973B

D. C. Whitehead, Studies of Iodine in British Soils, J. Soil Sci. 24, 260 (1973).

WH ITEHEAD-1974A

D. C. Whitehead, The Influence of Organic Matter, Chalk, and Sesquioxides on the Solubility of Iodide Elemental Iodine and Iodate Incubated with Soil, J. Soil Sci. 25, 461 (1974).

WHITEHEAD-1974B

D. C. Whitehead, The Sorption of Iodide by Soil Componeats, J. Sci. Food Agric. 25, 73 (1974).

WHITEHEAD-1978

D. C. Whitehead, Iodine in Soil Profiles in Relation to Iron and Aluminum Oxides and Organic Matter, J. Soil Sci. 29, 88 (1978).

WIENEKE-1979

R. E. Wieneke, J. J. Dauby, G. C. Abe11, W. E. Tadlock, P. H. Lamberger, and G. E. Gibbs, Polymer Impregnated Tritiated Concrete: Final Report, Monsanto Research Corporation, Mound Facility, U.S. Dept. of Energy

Report MLM-2644 (September 1979).

WIENEKE-1982

R. E. Wieneke, Monsanto Research Corp., Inc, Mound Laboratory, personal communication to L. E. Trevorrow, August 4, 1982.

W!ILDING

R. E. Wilding, R. C. Rout son, R. J. Serne, and T. R. Garl and, Pertechnetate, Iodide and Methyl Iodide Retention by Surface Soils, American Agronomy Society Annual Meet ing, Chicago, IL., CONF-741121-3, Battelle Northwest Laboratory Report BNWL-SA-5195 (October 1974). 
WINAR

R. M. Winar, L. E. Trevorrow, and M. J. Steindler, Feasibility of Underground Storage/Disposal of Noble Gas Fission Products, Argonne National Laboratory Report ANL-78-81 (August 1979).

WINTERS

W. I. Winters, Effect of Hot-Pressing Conditions on the Properties of Iodide Sodalite, Rockwell International, Rockwell Hanford Operations Report RHO-LD-153 (December 1980).

WIPP-DOE-069

TRU Waste Acceptance Criteria for the Waste Isolation Pilot Plant, Rev. 1 (Sept. 1981).

WIPP-DOE- 114

TRU Waste Certification Compliance Requirements for Newly Generated Contact-Handled Wastes for Shipment to the WIPP (Oct. 1981).

\section{WITTENBERG}

L. J. Wittenberg, W. R. Wilkes, and C. J. Kershner, Environmental Control of the Tritium Inventory in a Fusion Reactor Facility, Proc. Second Topical Meeting on the Technology of Controlled Nuclear Fusion, September 1976, Richland, WA, G. L. Kulcinski, Ed,, Vol. IV, U.S. ERDA Report CONF-760935, P-4.

WOLFSBERG-i 978

K. Wolfsberg, Sorption-Desorption Studies of Nevada Test Site, Alluvium and Leading Studies of Nuclear Test Debris, Los Alamos National Laboratory Report LA-7216-MS (April 1978).

WOLFSBERG-1980

K. Wolfsberg, B. R. Erdal, and J. R. Smyth, Compilers, Research and Development Related to the Nevada Nuclear Waste Storage Investigations, Apri1 1-June 30, 1980, Los Alamos National Laboratory Report LA-8471-PR.

WOOD

W. Wood and A. C. B. Richardson, Considerations Bearing on the Disposal of I-129, Compte Rendu d'une re'union de Specialistes de l'AEN, Paris, p. $90(1977)$.

YAMAMOTO

Y. Yamamoto, Y. Sawada, and B. An, Long-Term Storage of Radioactive

Krypton Using Adsorbent and a Double Cylinder, Proc. 16th DOE

Nuclear Air Cleaning Conference, San Diego, CA, 1980, CONF-801083, p. $1047 \mathrm{ff}(1981)$.

\section{Y/OWI/TM-44}

Contribution to Draft Generic Environmental Impact Statement on Commercial Waste Management: Radioactive Waste Isolation in Geologic Formations, Office of Waste Isolation/Union Carbide Corporation, Nuclear Division Report Y/OWI/ $\mathrm{TM}-44$ (April 1978). 
10 CFR 20

Code of Federal Regulations, Title 10, Part 20, Standards for Protection Against Radiation.

10 CFR 60

Disposal of High-Level Radioactive Wastes in Geologic Repositories Technical Criteria, U.S. Nuclear Regulatory Commission, Final Rules, Code of Federal Regulations, Title 10, Part 60, Federal Register: Vol. 48, No. 120, pp. 28194-28229 (Tuesday, June 21, 1983).

10 CFR 61

Proposed Rules, 10 CFR Parts 2, 19, 20, 21, 30, 40, 51, 61, 70, 73, and 170 , Licensing Requirements for Land Disposal of Radioactive Waste, U.S. Nuclear Regulatory Commission, Federal Register, Vol. 46, No. 142, (Friday, July 24, 1981).

10 CFR 71

Packaging of Radioactive Material for Transport and Transportation of Radioactive Material Under Certain Conditions, U.S. Nuclear Regulatory Commission, Code of Federal Regulations, Tití 10, Part 71.

40 CFR 190

Environmental Radiation Protection Standard, for Nuclear Power Stations, U.S. Envi ronmental Protection Agency, Code if Federal Regulations, Title 40, Part 190.

40 CFR 191

Environmental Standards for the Management and Dispusal of Spent Nuclear Fuel, High-Level and Transuranic Radioactive Wastes, U.S. Environmental Protection Agency, Proposed Rule, Code of Fede:al Regulations, Title 10 , Part 191, Federal Register, Vol. 47, No. 250, p. 58196

(December 29, 1982).

49 CFR $171-179$

U.S. Dt:partinent of Transportation, Code of Federal Regulations, Title 49, Transportation, Subtitle B--Other Regulations Relating to Transportation, Chapter I--Research and Special Frograms Administration, Department of Transportation, Subchapter C--Hazardous Materials Regulations: Part 171, General Information, Regulations, and Definitic:s; Part 172, Hazardous Materials Table and Hazardous Materials Communications Regulations; Part 173, Shippers-General Requirements for Shipments and Packaging; Part 174, Carriage by Rail; Part 175, Carriage by Aircraft; Part 176, Carriage by Vessel; Part 17\%, Carriage by Public Highway; Part 178, Shipping Cuntainer Specifications; and Part 179, Specifications for Tank Cars. 


\section{Distribution for ANL-83-57 Part I}

Internal:
E. S. Beckjord
C. Luner
C. E. Till
M. J. Steindler (4)
J. J. Barghusen
L. E. Trevorrow (10)
L. Burris
P. A. Finn
G. F. Vandegrift
J. E. Harmon
S. Vogler
R. B. Keener
J. H. Kittel.
ANL Patent Dept.
ANL Contract File
V. M. Kolba
ANL Libraries (4)
TIS Files (6)

\section{Externa1:}

DOE-TIC, for distribution per UC-70 (310)

Manager, Chicago Operations office, DOE

$\mathrm{J}$. Haugen, DOE-CH

Chemical Technology Division Review Committee Merbers:

C. B. Alcock, U. Toronto

S. Barnn, Burn:s and Roe, Inc., Oradel1, N. J.

W. N. Delgass, Purdue U.

P. Alexander, TRW, Inc., Lakewood, Colo.

R. Barletta, Brookhaven National lab.

M. Be11, U. S. Nuclear Regulatory Commission, Washington

R. A. Brown, Exxon Nuclear Idaho Co., Inc., Idaho Falls

L. Burger, Battelle Pacific Northinest Lab.

J. D. Christian, Exxon Nuclear Idaho Co., Inc., Idaho Falls

A. G. Croff, Oak Ridge National Lab.

L. Dole, Oak Ridge National Lab.

K. Dragonette, U. S. Nuclear Regulatory Commission, Washington

D. Edling, Mound Facility

J. Gruhlke, U. S. Environmental Protection Agency, Washington

G. Haag, Amoco Production Co. Research Center, Tulsa

P. Hunter, Science Applications, Inc., Sandy, Itah

R. M. Jefferson, Sandia Natioral Labs., Albuquerque

T. C. Johnson, U. S. Nuclear Regulatory Commission, Washington

R. D. Klett, Sandia National Labs., Albuquerque

D. Knecht, Exxon Nuclear Idaho Co., Inc., Idaho Fa11s

G. Levin, EG\&G Idaho, Idaho Falls

M. Rogers, Mound Facility

T. Thomas, Exxon Nuclear Idaho Co., Inc., Idaho Falls

G. Tingey, Battelle Pacific Northwest Lab.

B. Thamer, Ford, Bacon \& Davis Utah, Inc., Salt Lake City

J. B. Whitsett, U. S. Department of Energy, Idaho Falls

M. A. Widmayer, U. S. Department of Energy, Idaho Falls 